ISSN 2413-1407 (Print), 2587-8549 (Online)

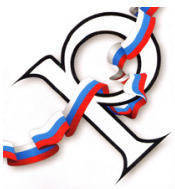

\title{
РЕГИОНОЛОГИЯ REGIONOLOGY
}

\section{Том 29, № 2, 2021 (апрель - июнь) \\ Сквозной номер выпуска - 115}

Научный журнал

УЧРЕДИТЕЛЬ И ИЗДАТЕЛЬ:

федеральное государственное бюджетное образовательное учреждение высшего образования «Национальный исследовательский Мордовский государственный университет им. Н. П. Огарёва»

430005, Российская Федерация, Республика Мордовия, г. Саранск, ул. Большевистская, 68

АДРЕС РЕДАКЦИИ:

430005, Российская Федерация, Республика Мордовия, г. Саранск, ул. Большевистская, 68/1

Тел./факс: +7 (8342) 48-14-24, +7 (8342) 32-86-14

Журнал издается с 1992 года. Периодичность издания - 4 раза в год

\section{DOI: $10.15507 / 2413-1407$}

\section{Russian Journal of Regional Studies}

\author{
Vol. 29, No. 2, 2021 (April - June) \\ Continuous issue 115 \\ Scholarly journal \\ FOUNDER AND PUBLISHER:
}

Federal State Budgetary Educational Institution of Higher Education

"National Research Ogarev Mordovia State University"

68 Bolshevistskaya St., Saransk 430005, Republic of Mordovia, Russian Federation

EDITORIAL OFFICE:

68/1 Bolshevistskaya St., Saransk 430005, Republic of Mordovia, Russian Federation Tel/Fax: +7 8342 481424, +7 8342328614

Published since October 1992. Publication frequency: quarterly

e-mail: regionology@mail.ru, redreg@mrsu.ru

http://regionsar.ru

(C) ФГБОУ ВО «МГУ им. Н. П. Огарёва», 2021 
Основное содержание журнала составляют оригинальные научные статьи, посвященные актуальным проблемам региональной политики, экономики и социологии, анализу комплексного развития регионов Российской Федерации и зарубежных стран. Наименование и содержание рубрик журнала соответствуют отраслям науки и группам специальностей научных работников на основании Номенклатуры научных специальностей, по которым присуждаются ученые степени:

\section{ЭКОНОМИКА}

СОЦИОЛОГИЯ

\section{Политология}

Журнал осуществляет научное рецензирование всех поступающих в редакцию материалов.

Политика редакционной коллегии журнала базируется на современных юридических требованиях в отношении клеветы, авторского права, законности и плагиата, поддерживает Кодекс этики научных публикаций, сформулированный Комитетом по этике научных публикаций, и строится с учетом этических норм работы редакторов и издателей, закрепленных в Кодексе поведения и руководящих принципах наилучшей практики для редактора журнала и Кодексе поведения для издателя журнала, разработанных Комитетом по публикационной этике (СОРЕ).

Журнал индексируется и архивируется в Web of Science Core Collection (ESCI), Российском индексе научного цитирования (РИНЦ), крупнейшем агрегаторе научных ресурсов ведущих издательств мира EBSCO, реферативной базе данных ERIH PLUS, научной электронной библиотеке «КиберЛенинка», электронно-библиотечной системе «Лань», базе данных Ulrichsweb Global Serials Directory, Немецкой национальной экономической библиотеке Лейбница.

Журнал является членом Directory of Open Access Journals (DOAJ), Ассоциации научных редакторов и издателей (АНРИ), CrossRef и международного сообщества рецензентов Publons.

Журнал входит в Перечень рецензируемых научных изданий, в которых должны быть опубликованы основные научные результаты диссертаций на соискание ученой степени кандидата наук, на соискание ученой степени доктора наук, по научным специальностям и соответствующим им отраслям.

\section{Социально-экономические и общественные науки}

08.00.05 - Экономика и управление народным хозяйством (по отраслям и сферам деятельности)

22.00 .04 - Социальная структура, социальные институты и процессы

23.00 .02 - Политические институты, процессы и технологии

23.00 .04 - Политические проблемы международных отношений, глобального и регионального развития 
The main contents of the Journal are original scientific papers devoted to topical issues of regional policy, economy and sociology, as well as to the analysis of the integrated development of the regions of the Russian Federation and other countries. The names and content of the Journal's sections correspond to the fields of science and groups of specialties of scientific workers in accordance with the Nomenclature of Scientific Specialties in which academic degrees are awarded:

\section{ECONOMICS}

SOCIOLOGY

\section{POLITICAL SCIENCE}

The Journal conducts scientific review of all papers submitted to the Editorial Office.

The Editorial Board's policy is based on modern legal requirements concerning libel, copyright, legality and plagiarism. It complies with the Code of Ethics of Scientific Publications, formulated by the Committee on the Ethics of Scientific Publications, and is implemented taking into account the ethical standards of work of editors and publishers enshrined in the Code of Conduct and Best Practice Guidelines for Journal Editors developed by the Committee on Publication Ethics (COPE).

The Journal is indexed and archived in Web of Science Core Collection (Emerging Sources Citation Index), in Russian Index of Scientific Citation, in EBSCO, the largest aggregator of scientific resources of the world's leading publishing houses, in ERIH PLUS reference index, in CyberLeninka scientific electronic library, in Lan electronic library system, in UlrichsWeb Global Serials Directory international reference database of periodicals and in German National Library of Economics $(Z B W)$.

The journal is a member of the Directory of Open Access Journals (DOAJ), Association of Scientific Editors and Publishers (ASEP), CrossRef and Publons international peer-review community.

The Journal is included in the Higher Attestation Commission List of the Peer-Reviewed Scientific Publications where the Main Scientific Results of Ph. D. and Doctoral Theses (by applicants for Candidate of Sciences and Doctor of Sciences degrees) in scientific specialties and their respective branches should be published.

\section{Socio-Economic and Social Sciences}

Economics and National Economy Management

Social Structure, Social Institutions and Processes

Political Institutions, Processes and Technology

Political Issues of International Relations, Global and Regional Development 


\section{РЕДАКЦИОННАЯ КОЛЛЕГИЯ}

Вдовин Сергей Михайлович - главный редактор, ректор ФГБОУ ВО «МГУ им. Н. П. Огарёва», кандидат экономических наук, доцент, ORCID: https:/orcid.org/ 0000-0001-7363-1389, rector@adm.mrsu.ru (Саранск, Российская Федерация)

Полутин Сергей Викторович - заместитель главного редактора, директор НИИ регионологии ФГБОУ ВО «МГУ им. Н. П. Огарёва», доктор социологических наук, профессор, ORCID: https://orcid.org/0000-0003-0399-4154, polutin.sergei@yandex.ru (Саранск, Российская Федерация)

Гордина Светлана Викторовна - ответственный секретарь, член Европейской ассоциации научных редакторов (EASE), кандидат педагогических наук, ORCID: https://orcid.org/0000-0003-2265-418X, inted@adm.mrsu.ru, inted@mail.ru (Саранск, Российская Федерация)

Ахмад Наср Салех Мохамад - профессор бухгалтерского учета, факультет бухгалтерского учета Университета Гарьяна, генеральный директор Института персонала Ливийской академии, ORCID: https://orcid.org/0000-0002-2057-2220, nassr_ahmad@yahoo.co.uk (Гарьян, Ливия)

Барыгин Игорь Николаевич - профессор кафедры социологии ФГБОУ ВО «Санкт-Петербургский государственный университет», кандидат философских наук, доктор политических наук, профессор, ORCID: https://orcid.org/0000-0002-8143-3136, ibarygin@gmail.com (Санкт-Петербург, Российская Федерация)

Бахлов Игорь Владимирович - заведующий кафедрой всеобщей истории, политологии и регионоведения ФГБОУ ВО «МГУ им. Н. П. Огарёва», доктор политических наук, доцент, ORCID: https://orcid.org/0000-0001-6886-5762, bahlov@mail.ru (Саранск, Российская Федерация)

Большаков Андрей Георгиевич - заведующий кафедрой конфликтологии ФГАОУ ВО «Казанский (Приволжский) федеральный университет», доктор политических наук, доцент, ORCID: https://orcid.org/0000-0002-5036-000X, bolshakov_andrei@mail.ru (Казань, Российская Федерация)

Гришин Виктор Иванович - доктор экономических наук, профеccop, grv655898@gmail.com (Москва, Российская Федерация)

Дахин Андрей Васильевич - заведующий кафедрой философии и политологии Нижегородского института управления - филиала ФГБОУ ВО «Российская академия народного хозяйства и государственной службы при Президенте Российской Федерации», доктор философских наук, профессор, ORCID: https://orcid.org/ 0000-0001-5907-706X, nn9222@rambler.ru (Нижний Новгород, Российская Федерация)

Дружинин Павел Васильевич - заведующий отделом моделирования и прогнозирования регионального развития Института экономики ФГБУН «Карельский научный центр Российской академии наук», доктор экономических наук, доцент, ORCID: https:/orcid. org/0000-0001-5303-0455, pdruzhinin@mail.ru (Петрозаводск, Российская Федерация)

Дулина Надежда Васильевна - профессор кафедры социологии и социальных технологий ФГАОУ ВО «Волгоградский государственный университет», доктор социологических наук, профессор, ORCID: https://orcid.org/0000-0002-6471-7073, nv-dulina@yandex.ru (Волгоград, Российская Федерация) 
Кизима Сергей Анатольевич - профессор кафедры международных отношений Академии управления при Президенте Республики Беларусь, доктор политических наук, профессор, ORCID: https://orcid.org/0000-0003-0725-5391, kizima@mail.ru (Минск, Республика Беларусь)

Ковалев Виктор Антонович - профессор кафедры политологии и международных отношений ФГБОУ ВО «Сыктывкарский государственный университет им. Питирима Сорокина», доктор политических наук, доцент, ORCID: https://orcid.org/ 0000-0003-3691-4106, vant_2000@mail.ru (Сыктывкар, Российская Федерация)

Лапин Анатолий Евгеньевич - заведующий кафедрой экономического анализа и государственного управления ФГБОУ ВО «Ульяновский государственный университет», доктор экономических наук, профессор, ORCID: https://orcid.org/0000-0003-1467-0358, eagov01@mail.ru (Ульяновск, Российская Федерация)

Макарова Марина Николаевна - профессор кафедры социологии ФГБОУ ВО «Удмуртский государственный университет», доктор социологических наук, доцент, ORCID: https://orcid.org/0000-0003-3176-6386, makmar11@mail.ru (Ижевск, Российская Федерация)

Немировский Валентин Геннадьевич - главный редактор журнала «Сибирский социум / Siberian Socium», доктор социологических наук, професcop, ORCID: https:// orcid.org/0000-0002-4076-465X, valnemirov@mail.ru (Тюмень, Российская Федерация)

Резник Галина Александровна - заведующий кафедрой маркетинга и экономической теории ФГБОУ ВО «Пензенский государственный университет архитектуры и строительства», доктор экономических наук, профессор, ORCID: https:/orcid.org/ 0000-0003-4575-1812, reznikga@gmail.com (Пенза, Российская Федерация)

Садвокасова Айгуль Какимбековна - руководитель Центра по изучению межэтнических и межконфессиональных отношений в Центрально-Азиатском регионе Академии государственного управления при Президенте Республики Казахстан, доктор социологических наук, ORCID: https://orcid.org/0000-0002-3467-0833, aigul-kaz@yandex.ru (Астана, Казахстан)

Симанавичене Жанета - заведующий лабораторией инноваций в предпринимательстве Университета Миколаса Ромериса, доктор экономических наук, профессор, ORCID: https://orcid.org/0000-0001-6008-2405, zasiman@mruni.eu (Вильнюс, Литва)

Спринчан Сергей Леонидович - ученый секретарь и ведущий научный сотрудник Института юридических и политических исследований Академии наук Молдовы, доктор политологии, доцент, ORCID: https://orcid.org/0000-0002-7411-9958, sprinceans@yahoo.com (Кишинев, Республика Молдова)

Туровский Ростислав Феликсович - вице-президент Центра политических технологий, доктор политических наук, доцент, ORCID: https://orcid.org/0000-0001-8496-3098, rft777@mail.ru (Москва, Российская Федерация)

Шалаев Владимир Павлович - декан факультета социальных технологий ФГБОУ ВО «Поволжский государственный технологический университет», доктор философских наук, профессор, ORCID: https://orcid.org/0000-0001-9155-695X, shalaevvp@volgatech.net (Йшкар-Ола, Российская Федерация) 


\section{EDITORIAL BOARD}

Sergey M. Vdovin - Editor-in-Chief, Rector of National Research Mordovia State University, Cand. Sci. (Economics), Associate Professor, ORCID: https://orcid.org/ 0000-0001-7363-1389, rector@adm.mrsu.ru (Saransk, Russian Federation)

Sergey V. Polutin - Deputy Editor-in-Chief, Director of Research Institute of Regionology, National Research Mordovia State University, Dr. Sci. (Sociology), Full Professor, ORCID: https://orcid.org/0000-0003-0399-4154, polutin.sergei@yandex.ru (Saransk, Russian Federation)

Svetlana V. Gordina - Executive Editor, Member of European Association of Science Editors (EASE), Cand. Sci. (Pedagogy), ORCID: https://orcid.org/0000-0003-2265-418X, inted@adm.mrsu.ru, inted@mail.ru (Saransk, Russian Federation)

Nassr S. M. Ahmad - Professor of Accounting, Faculty of Accounting, University of Gharyan, General Manager of Human Resources Development Institute, Libyan Academy, ORCID: https://orcid.org/0000-0002-2057-2220, nassr_ahmad@yahoo.co.uk (Ghrian, Libya)

Igor V. Bakhlov - Head of Department, Department of World History, Political Science and Regional Studies, National Research Mordovia State University, Dr. Sci. (Political Science), Associate Professor, ORCID: https://orcid.org/0000-0001-6886-5762, bahlov@mail.ru (Saransk, Russian Federation)

Igor N. Barygin - Professor, Department of Sociology, St. Petersburg State University, Cand. Sci. (Philosophy), Dr. Sci. (Political Science), Full Professor, ORCID: https://orcid. org/0000-0002-8143-3136, ibarygin@gmail.com (St. Petersburg, Russian Federation)

Andrey G. Bolshakov - Head of Department, Department of Conflict Resolution, Kazan (Volga) Federal University, Dr. Sci. (Political Science), Associate Professor, ORCID: https://orcid.org/0000-0002-5036-000X, bolshakov_andrei@mail.ru (Kazan, Russian Federation)

Andrey V. Dakhin - Head of Department, Department of Philosophy and Political Science, Nizhny Novgorod Institute of Management - Branch of the Russian Presidential Academy of National Economy and Public Administration, Dr. Sci. (Philosophy), Full Professor, ORCID: https://orcid.org/0000-0001-5907-706X,nn9222@rambler.ru (Nizhny Novgorod, Russian Federation)

Pavel V. Druzhinin - Head of Department, Department of Modeling and Prognostication of Regional Development, Institute of Economics, Karelian Research Center of the Russian Academy of Sciences, Dr. Sci. (Economics), Associate Professor, ORCID: https://orcid.org/0000-0001-5303-0455, pdruzhinin@mail.ru (Petrozavodsk, Russian Federation)

Nadezhda V. Dulina - Professor, Department of Sociology and Social Technologies, Volgograd State University, Dr. Sci. (Sociology), Full Professor, ORCID: https:// orcid.org/0000-0002-6471-7073,nv-dulina@yandex.ru (Volgograd, Russian Federation)

Viktor I. Grishin - Dr. Sci. (Economics), Full Professor, grv655898@gmail.com (Moscow, Russian Federation)

Sergey A. Kizima - Professor, Department of International Relations, Academy of Public Administration under the President of the Republic of Belarus, Dr. Sci. (Political Science), Full Professor, ORCID: https://orcid.org/0000-0003-0725-5391, kizima@mail.ru (Minsk, Republic of Belarus) 
Viktor A. Kovalev - Professor, Department of Political Science and International Relations, Pitirim Sorokin Syktyvkar State University, Dr. Sci. (Political Science), Associate Professor, ORCID: https://orcid.org/0000-0003-3691-4106, vant_2000@mail.ru (Syktyvkar, Russian Federation)

Anatoly E. Lapin - Head of Department, Department of Economic Analysis and Public Administration, Ulyanovsk State University, Dr. Sci. (Economics), Full Professor, ORCID: https://orcid.org/0000-0003-1467-0358, eagov01@mail.ru (Ulyanovsk, Russian Federation)

Marina N. Makarova - Professor, Department of Sociology, Udmurt State University, Dr. Sci. (Sociology), Associate Professor, ORCID: https://orcid.org/0000-0003-3176-6386, makmar11@mail.ru (Izhevsk, Russian Federation)

Valentin G. Nemirovskiy - Editor-in-Chief, "Siberian Socium” Journal, Dr. Sci. (Sociology), Full Professor, ORCID: https://orcid.org/0000-0002-4076-465X, valnemirov@mail.ru (Tyumen, Russian Federation)

Galina A. Reznik - Head of Department, Department of Marketing and Economic Theory, Penza State University of Architecture and Construction, Dr. Sci. (Economics), Full Professor, ORCID: https://orcid.org/0000-0003-4575-1812, reznikga@gmail.com (Penza, Russian Federation)

Aigul K. Sadvokassova - Director of the Center for the Study of Interethnic and Interfaith Relations in the Central Asian Region, Academy of Public Administration under the President of the Republic of Kazakhstan, Dr. Sci. (Sociology), ORCID: https://orcid.org/0000-0002-3467-0833, aigul-kaz@yandex.ru (Astana, Republic of Kazakhstan)

Vladimir P. Shalaev - Dean, Faculty of Social Technologies, Volga State University of Technology, Dr. Sci. (Philosophy), Full Professor, ORCID: https://orcid.org/ 0000-0001-9155-695X, shalaevvp@volgatech.net (Yoshkar-Ola, Russian Federation)

Žaneta Simanavičienè - Head of Business Innovation Laboratory, Mikolas Romeris University, Dr. Sci. (Economics), Full Professor, ORCID: https://orcid.org/0000-0001-6008-2405, zasiman@mruni.eu (Vilnius, Lithuania)

Serghei L. Sprincean - Academic Secretary and Leading Researcher, Institute of Legal and Political Research, Academy of Sciences of Moldova, Dr. Sci. (Political Science), Associate Professor, ORCID: https://orcid.org/0000-0002-7411-9958, sprinceans@yahoo.com (Chisinau, Republic of Moldova)

Rostislav F. Turovsky - Vice-President, Center for Political Technologies, Dr. Sci. (Political Science), Associate Professor, ORCID: https://orcid.org/0000-0001-8496-3098, rft777@mail.ru (Moscow, Russian Federation) 


\section{СОДЕРЖАНИЕ}

\section{Политическая регионалистика. Этнополитика}

Е. И. Гайданка. Электоральные разграничения и фрагментация регионов Словакии (кейс парламентских выборов 1990-2020 гг.)

\section{Экономика и управление народным хозяйством}

В. В. Климанов, С. М. Казакова, В. А. Яговкина. Инструменты межрегионального взаимодействия в системе государственного управления.....

Я. Ю. Еферин. Роль стратегий в диверсификации экономики регионов: запланированное развитие против незапланированных результатов

Н. Д. Гуськова, А. В. Ерастова, Д. В. Никитина. Стратегическое управление устойчивым развитием предприятий малого бизнеса.

\section{Экономическая социология и демография}

Т. А. Салимова, Л. И. Бирюкова, Н. В. Аникина. Трансформация бизнеса в условиях цифровой экономики: зарубежный подход и российские возможности...... 328

А. А. Михайлова, Е. Н. Тимушев. Детерминанты кредитных рейтингов регионов России

Н. Ф. Колесник, В. В. Акашева, О. В. Шибилева. Развитие крестьянских (фермерских) хозяйств как фактор стабилизации и улучшения качества жизни сельского населения 380

К. Ю. Волошенко. Экономическая безопасность в границах экономической сложности ... 401

\section{Социальная структура, социальные институты и процессы}

А. Е. Курило. Долгосрочные тенденции региональных рынков труда в России.....

Н. П. Касаткина, Н. В. Шумкова, Н. Г. Токарева. Поселенческое неравенство и социальная эксклюзия людей с эпилепсией.

Информация для авторов и читателей (на рус. яз.) 
http://regionsar.ru

DOI: $10.15507 / 2413-1407.115 .029 .202102$

ISSN 2587-8549 (Print)

ISSN 2413-1407 (Online)

\section{CONTENTS}

\section{Political Regional Studies. Ethnopolitics}

Ye. I. Haydanka. Electoral Cleavages and Fragmentation of Regions in the Slovak

Republic: A Case Study of the Parliamentary Elections Held in 1990-2020 230

\section{Economics and Management of National Economy}

V. V. Klimanov, S. M. Kazakova, V. A. Yagovkina. Tools of Interregional Cooperation

in the Public Administration System.

Ya. Yu. Eferin. The Role of Strategies in Diversification of Regional Economies: Planned Development versus Unplanned Results....

N. D. Guskova, A. V. Erastova, D. V. Nikitina. Strategic Management of Sustainable Development of Small Business Enterprises 306

\section{Economic Sociology and Demography}

T. A. Salimova, L. I. Biryukova, N. V. Anikina. Business Transformation in the Digital Economy: The Foreign Approach and Russian Opportunities

A. A. Mikhaylova, E. N. Timushev. Determinants of Credit Ratings of Russia's Regions.... 355

N. F. Kolesnik, V. V. Akasheva, O. V. Shibileva. Development of Peasant Farm

Enterprises as a Factor in Stabilizing and Improving the Quality of Life of the Rural

Population 380

K. Yu. Voloshenko. Economic Security within the Limits of Economic Complexity 401

\section{Social Structure, Social Institutions and Processes}

A. E. Kurilo. Long-Term Trends in Regional Labor Markets in Russia

N. P. Kasatkina, N. V. Shumkova, N. G. Tokareva. Settlement Inequality and Social Exclusion of People with Epilepsy

Information for Authors and Readers of the Journal (in Russian)

Information for Authors and Readers of the Journal (in English) 
ПОЛИТИЧЕСКАЯ РЕГИОНАЛИСТИКА. ЭТНОПОЛИТИКА / POLITICAL REGIONAL STUDIES. ETHNOPOLITICS

УДК 323.174(437.6)

DOI: $10.15507 / 2413-1407.115 .029 .202102 .230-249$

Оригинальная статья / Original article http://regionsar.ru

ISSN 2587-8549 (Print)

ISSN 2413-1407 (Online)

\section{Электоральные разграничения и фрагментация регионов Словакии (кейс парламентских выборов 1990-2020 гг.)}

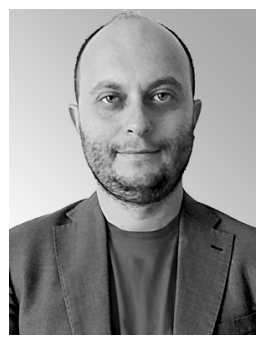

\author{
Е. И. Гайданка \\ Трнавский университет (2. Трнава, Словакия), \\ yevheniy.haydanka@truni.sk
}

Введение. Электоральные процессы в постсоциалистических странах определяют политико-партийную фрагментацию страны, разделяя регионы на более консервативные или либеральные, сторонников или противников «твердого руководства» страной, евроскептиков и еврооптимистов. Цель статьи - провести компаративный анализ результатов парламентских выборов в регионах, учитывая имеющиеся общественно-политические расколы и особенности формирования электоральных разграничений.

Материалы и методы. Основным материалом исследования являются результаты десяти парламентских выборов в современной Словакии (1990-2020 гг.). Эмпирический материал обрабатывался на макро- (вся Словакия) и микроуровнях (регионы Словакии). Комплексный компаративный метод позволил выделить основные общественнополитические расколы, на основе которых подтверждались или опровергались электоральные разграничения в регионах страны.

Результаты исследования. Определены основные общественно-политические расколы в Словакии. По итогам парламентских выборов в регионах Словакии зафиксировано шесть электоральных разграничений (в 1998, 2002, 2006, 2010, 2016 и 2020 гг.). Знаковыми для страны стали два общественно-политических раскола: «мечиаризм антимечиаризм» (1998 г.) и «Фицо - антиФицо» (2020г.). Фрагментация политикопартийного пространства Словакии включает две группы регионов: запад и восток (либералы и социальные популисты), а также центр (консерваторы).

Обсуждение и заключение. Результаты исследования могут быть использованы для разработки эффективной стратегии регионального развития, в основе которой раскрывается минимизация рисков радикализации политического пространства и уменьшение общего уровня популизма в стране.

Ключевые слова: регион, регионализация, политическая фрагментация Словакии, общественно-политический раскол, электоральное разграничение

Автор заявляет об отсутствии конфликта интересов.

(C) Гайданка Е. И., 2021

Контент доступен под лицензией Creative Commons Attribution 4.0 License. This work is licensed under a Creative Commons Attribution 4.0 License. 
Для циитирования: Гайданка, Е. И. Электоральные разграничения и фрагментация регионов Словакии (кейс парламентских выборов 1990-2020 гг.) / Е. И. Гайданка. - DOI 10.15507/2413-1407.115.029.202102.230-249// Регионология. - 2021. - Т. 29, № 2. C. 230-249.

\title{
Electoral Cleavages and Fragmentation of Regions in the Slovak Republic: A Case Study of the Parliamentary Elections Held in 1990-2020
}

\author{
Ye. I. Haydanka \\ Trnava University (Trnava, Slovak Republic), \\ yevheniy.haydanka@truni.sk
}

Introduction. Electoral processes in the post-socialist countries have determined their political and party fragmentation, dividing regions into more conservative or liberal ones, those supporting or opposing the "firm leadership" of the country, Eurosceptic or Eurooptimistic. The main objective of the article is to present a comparative analysis of the outcomes of parliamentary elections in the regions, given the existing socio-political splits and the peculiarities of formation of the electoral cleavages.

Materials and Methods. The study was based on the results of the ten parliamentary elections held in the Slovak Republic in 1990-2020. The empirical material covers the macro (national) and micro (regional) levels. The comprehensive comparative method made it possible to single out the main socio-political splits that either confirm or refute electoral cleavages in the regions of the country.

Results. The main socio-political splits in the Slovak Republic have been identified. Given the results of the parliamentary elections in the regions of Slovakia, six electoral cleavages have been recorded $(1998,2002,2006,2010,2016$, and 2020). Two socio-political splits of "Meciarism - anti-Meciarism" (1998) and "Fico - anti-Fico" (2020) proved to be of particular significance for the country. The fragmentation of the Slovak political and party space is represented by two groups of regions: West and East (liberals and social populists), as well as the Center (conservatives).

Discussion and Conclusion. The results of the study can be used when devising an efficient regional development strategy based on minimizing the risks of radicalization of the political space and reducing the overall level of populism in the country.

Keywords: region, regionalization, political fragmentation in the Slovak Republic, sociopolitical split, electoral cleavages

The author declares that there is no conflict of interest.

For citation: Haydanka Ye.I. Electoral Cleavages and Fragmentation of Regions in the Slovak Republic: A Case Study of the Parliamentary Elections Held in 1990-2020. Regionology $=$ Russian Journal of Regional Studies. 2021; 29(2):230-249. DOI: https://doi. org/10.15507/2413-1407.115.029.202102.230-249

Введение. Траектории трансформационных процессов на постсоциалистическом пространстве остаются актуальными до сих пор, ставя новые вопросы и заставляя ученых искать ответы на них. В любой стране мира, управленческая верхушка которой формируется электоральным путем, важным 
остается вопрос электоральных преференций граждан. Особенно это актуально в таких странах, как Словакия, где относительно недавно была своя история с безальтернативными выборами, а в последние три десятилетия выборы стали политической ареной борьбы между многообразием идеологий, авторитарных и либеральных взглядов на будущее «новой демократии». Конечно, нельзя забывать о дифференциации в электоральных предпочтениях на национальном и региональном уровнях, что, в свою очередь, формирует основные линии электорального разграничения между различными регионами страны.

Регионализация политики и связанные с ней электоральные разграничения в регионах определяют общую конфигурацию политико-партийной системы в современной Словакии. Парламентские выборы, как наиболее популярный тип выборов, являются своеобразным катализатором страны на степень политической монолитности или, наоборот, электоральных разграничений. Традиционные электоральные разграничения между политиками старой постсоциалистической традиции и новой демократической элитой, европозитивистами и евроскептиками, либералами и социал-демократами, популистами различных политических ориентаций находят свое отражение в системе электорального разграничения между восточными и западными регионами, центром и периферией, наиболее развитым западным столичным регионом и экономически депрессивным восточным регионом страны.

Цель статьи - по результатам анализа электоральных предпочтений словаков на парламентских выборах определить электоральные разграничения в современной Словакии на региональном уровне.

Обзор литературы. Электоральные процессы на постсоциалистическом пространстве длительное время вызывали интерес в западной компаративной науке с целью объяснения логики демократического транзита. Последние публикации в большей степени посвящены анализу политико-партийной среды в постсоциалистических странах, к которым относится и Словакия. Менее исследованной является проблематика политической фрагментации регионов Словакии. При подготовке исследования мы использовали, по нашему мнению, наиболее показательные научные разработки, которые способны объяснить дифференциацию в электоральном выборе словаков.

Рассматривая институциональную взаимосвязь между стратификацией в обществе и партийным выбором, невозможно не вспомнить отцов-основателей теории расколов (cleavages) C. Липсета и С. Роккана ${ }^{1}$. Предложенная теория социально-политических разграничений длительное время подтверждала электоральный выбор в обществах с разной историей, политической культурой и региональной дифференциацией внутри страны. Вместе с тем масштабный переход к демократии в регионе Центральной и Восточной Европы в конце XX в. привел к научной ревизии концепции С. Липсета

${ }^{1}$ Party Systems and Voter Alignments: Cross-National Perspectives / edited by S. M. Lipset, S. Rokkan. New York: The Free Press, 1967. 554 p. 
и С. Роккана [1] и стимулировал ее адаптацию к реалиям постсоциалистической эпохи $[2 ; 3]$. Одними из самых заметных таких «адаптаторов» стали К. Лоусон, А. Рьомелле и Г. Карасимеонов, которым на примере пяти постсоциалистических центральноевропейских стран удалось определить электоральную нестабильность как действенный фактор социально-политических разграничений [4]. Однако социально-политические расколы не являются предметом нашего исследования, хотя методологический принцип электоральных разграничений нами рассматривается.

Нужно заметить, что контекст электоральных разграничений в регионах Словакии не является широко изученным. Вместе с тем данная проблематика остается предметом интереса представителей компаративной политологии, социологов, а также политических географов. Каждый из авторов выделяет особенности электоральных разграничений современной Словакии и предлагает научный подход к решению указанной проблемы. Например, Э. Бакке и Н. Ситтер провели анализ электоральных девиаций и разграничений в постсоциалистических парламентах [5]. Авторам удалось определить главные факторы удач/неудач политических партий на парламентских выборах на протяжении двадцатилетнего периода (1992-2002 гг.). Кроме изменения избирательной модели, определяющими факторами, которые способствовали тому, что бывшие парламентские политические партии не смогли преодолеть избирательный барьер, были социально-политические разграничения. Учитывая сложность чешско-словацких отношений в период чехословацкого федерализма начала 1990-х гг., особо актуальным становится формирование социополитических разграничений в словацких регионах (В. Кривый, В. Феглова, Д. Балко 2 ). На примере классического социально-политического разграничения «город - деревня» определена электоральная фрагментация словацких регионов. Так, консерваторы (партия «Движение за демократическую Словакию») были более популярны в сельской местности, в то время как либеральные консерваторы - крестьянские демократы (партия «Словацкий демократический и христианский союз) - были поддержаны преимущественно городским электоратом. Характер трансформационных процессов в Словакии стал одним из определяющих в формировании социально-политических расколов. С демократическим транзитом страны связаны региональные электоральные разграничения на основе культурных (этнических, религиозных) и географических факторов (центр - периферия) (Б. Сабо и П. Татраи [6]).

Традиционные социально-политические разграничения не способствовали формированию в Словакии уравновешенной партийной системы по образцу западноевропейских стран. Доказательством тому является постепенная радикализация партийного пространства за счет популярности «Народной партии «Наша Словакия» и рост уровня социального популизма за счет партии «Курс» (Smer).

${ }^{2}$ Krivý V., Feglová V., Balko D. Slovensko a jeho regióny: Sociokultúrne súvislosti volebného správania. Bratislava: Nadácia Médiá, 1996. 414 s. 
В контексте изучения нашей проблематики следует отметить публикации, посвященные объяснению закономерностей электоральных «линий раскола» в Словакии на региональных выборах уровня NUTS-3 [7], анализирующие рост роли института независимых депутатов [8], закономерности электорального выбора между различными регионами Словакии на материалах трех парламентских выборов 2000-х гг. [9], парламентских выборов в постсоциалистический период 1990-х гг. [10], а также выборов в словацкий парламент в контексте политического противостояния между евроскептиками и еврооптимистами [11]. Важным является объяснение сущности и закономерностей регионального электорального процесса [12] и возможностей социально-экономического сопровождения процессов регионализации в транзитивной стране [13].

В контексте разнообразия предложенной научной литературы нами комплексно проанализирована электоральная история Словакии в контексте парламентских выборов, которая по состоянию на 2020 г. включает десять кампаний. Научная новизна исследования состоит в определении монолитности или дифференциации в электоральном выборе словаков на региональном уровне, учитывая современные электоральные циклы.

Материалы и методы. Поскольку основными задачами исследования являются определение «социально-политических разломов» в транзитивной и современной Словакии, а также их влияние на электоральные разграничения в регионах, то базовым материалом для сравнительного анализа нам служили результаты парламентских выборов. Временные рамки охватывают десять парламентских кампаний, начиная с первых альтернативных выборов 1990 г. и до последних выборов 2020 г. Для определения электоральных преференций словаков была обработана избирательная явка на парламентских выборах, определена специфика политических программ наиболее видных партийных субъектов, дана характеристика риторике влиятельных политических деятелей.

Исследование электоральных разграничений проводилось на макро(в рамках всей Словакии) и микроуровне (на уровне восьми самоуправляющихся краев). Анализ электоральных колебаний охватил полностью региональный уровень NUTS-3, на котором сопоставлялись результаты выборов в Национальный совет. Основными объектами для сравнительного анализа стали края, которые расположились на разных полюсах: западный столичный Братиславский край (на границе с Австрией и Венгрией) со значимыми перспективами в социально-экономическом развитии ${ }^{3}$ и западноевропейским электоральным менталитетом; и восточнословацкий Прешовский край (имеет общую границу с Польшей и Украиной), который по социально-экономическим показателям является самым депрессивным регионом страны ${ }^{4}$,

\footnotetext{
${ }^{3}$ Bratislavský kraj - charakteristika regiónu. Štatistický úrad SR [Электронный pecypc]. URL: https:// slovak.statistics.sk/wps/portal/ext/themes/regional/bratislava/about (дата обращения: 28.01.2021).

${ }^{4}$ Prešovský kraj - charakteristika regiónu. Štatistický úrad SR [Электронный pecypc]. URL: https://slovak.statistics.sk/wps/portal/ext/themes/regional/presovsky\%20kraj/about (дата обращения: 28.01.2021).
} 
в котором также устойчивы постсоциалистические традиции поведения избирателя. Для получения полноценной картины электоральной фрагментации в регионах Словакии два основных общественно-политических раскола, которые, по нашему мнению, были наиболее значимыми, рассматриваются в масштабах всех регионов страны.

Основным методологическим принципом стал комплексный политологический и социологический анализ, который позволил определить доминирующие общественно-политические расколы накануне парламентских выборов и сопоставить эти разграничения с уровнем электоральной поддержки конкретных политических субъектов в регионах страны.

Результаты исследования. Тенденции политического развития Словакии и электоральные разграничения на региональном уровне. Наиболее популярными среди словацких избирателей со времен падения социалистического режима стали выборы в парламент. Средняя явка на парламентских выборах составляет 70,7 \%. Это самый высокий показатель избирательной явки по сравнению с другими выборами. Такой результат свидетельствует о приоритете государственной политики, которая реализуется на коллегиальной основе. Словацкий избиратель предпочитает выбирать конкретную партийную идеологию и конкретного политического лидера, который должен отстаивать эту идеологию на уровне Правительства (например, И. Матович от партии «Обычные люди» (OLaNO)). Поскольку по уровню избирательной явки выборы в Национальный совет являются приоритетом словацкого избирателя, рассмотрим региональные электоральные разграничения на примере именно этого типа выборов.

Первой линией электорального разграничения на региональном уровне могли стать свободные парламентские выборы 1990 г. Это были традиционные парламентские выборы для большинства постсоциалистических стран, когда через ротацию политических элит фактически закладывался общегосударственный курс на демократизацию 5 . Главной оппозиционной политической силой, с которой были связаны надежды на демонтаж социалистической системы и будущие демократические перемены, стала организация «Общественность против насилия» - ОПН (Verejnost' proti násiliu, VPN). По результатам выборов в Национальный совет Словацкой Республики электоральное разграничение между западом и востоком не подтвердилось, так как результаты оказались фактически идентичными. Победителем, как на западе, так и на востоке, оказалась ОПН, которая в столице страны, г. Братиславе, получила

${ }^{5}$ Такая ротация политических элит и приход к власти бывших оппозиционеров были свойственны и для других стран Центральной Европы. Например, на выборах в Сейм в 1989 г. в Польше свою избирательную квоту полностью заполняет оппозиционное движение «Солидарность» во главе с Л. Валенсой; в чешских представительных институтах власти в 1990 г. побеждает антикоммунистический «Гражданский форум» с В. Клаусом; после парламентских выборов 1990 г. в Венгрии доминируют бывшие оппозиционные политические силы - «Венгерский демократический форум» и «Альянс свободных демократов». 
$38,29 \%$, а в Восточнословацком крае ${ }^{6}-35,25 \%{ }^{7}$. Необходимо отметить, что Коммунистическая партия Чехословакии - КПЧ (Komunistická strana ČeskoSlovenska, KSČ) также получила в регионах одинаковый уровень поддержки: в Братиславе - 14,89 \%, в Прешовском крае - 14,74 \%. В этом контексте интересно предположение будущего президента Чешской Республики М. Земана, что получение коммунистами около 30 \% голосов ${ }^{8}$ приведет к уменьшению темпов демократизации и возрождению коммунистического строя в ближайшие два года9 ${ }^{9}$ В общем, в контексте первых свободных выборов электоральное разграничение на региональном уровне в Словакии не подтвердилось.

Следующие парламентские выборы состоялись в 1992 г., и на региональном уровне линией электорального разграничения мог стать фактор будущего формата чехословачкой федерации и возможной независимости Словакии. Страна как раз переживала заметное обострение политического противостояния между сторонниками и противниками независимости Словакии. Вместе с тем будущий формат словацкого государства так или иначе должен был включать полноценный государственный суверенитет, принятие которого в своих предвыборных обещаниях отстаивали будущие победители - партия «Движение за демократическую Словакию» - ДЗДС (Hnutie za demokratické Slovensko, HZDS). Следует отметить, что с 1992 г. начинается доминирование «мечиаризма» в словацкой политической системе [14]. По итогам во многом хаотичной политической борьбы между более чем 20 субъектами победу одерживает ДЗДС с результатом в $37,26 \%$ голосов ${ }^{10}$. Партия стала победителем как в г. Братиславе $(30,05$ \%), так и в Восточнословацком крае $(28,18 \%)$. Соответственно, и на парламентских выборах 1992 г. электоральное разграничение между западом и востоком не подтвердилось.

${ }^{6}$ В период 1990-1996 гг. Восточнословацкий край объединял полностью Прешовский, Кошицкий и небольшую часть Бансько-Быстрицкого края; в 1996 г. сформировано восемь новых региональных субъектов (краев): Прешовский, Кошицкий, Жилинский, Бансько-Быстрицкий, Тренчианский, Трнавский, Нитрианский и столичный Братиславский (Закон Национального совета Словацкой Республики о территориально-административном устройстве Словацкой Республики № 221 от 03.07.1996).

${ }^{7}$ Výsledky volieb rok 1990. Vol'by a referendá. Štatistický úrad Slovenskej republiky [Электронный pecypc]. URL: https://volby.statistics.sk/nrsr/snr1990/volby90_s/pph90.htm (дата обращения: 20.12.2020).

${ }^{8}$ Кое в чем это утверждение М. Земана перекликается с теорией консолидированной демократии известного американского компаративиста Ф. Шмиттера (Schmitter P. The Consolidation of Political Democracies: Processes, Rhythms, Seqiences and Types // Transition to Democracy / ed. by G. Pridham. Dartmouth: Aldershot-Brookfield, 1995. Pp. 535-568). Ученый утверждает, что достижение в переходном обществе уровня консолидированной демократии возможно, когда на уровне общественности новую демократию поддерживают не менее $70 \%$, а авторитарный режим старого образца (коммунистический) - не более 15 \% граждан. В таком случае, главной задачей новой элиты остается проведение эффективных демократических реформ, чтобы 15 \% нейтрально настроенных граждан не стали приверженными к авторитарным методам управления государством.

${ }_{9}^{9}$ Čupka M. Prvé slobodné vol'by pred 25 rokmi: Áno gulášu, nie čerešniam [Электронный реcypc]//Pravda. 05. jun. 2015. URL: https://zurnal.pravda.sk/spolocnost/clanok/357503-prve-slobodnevolby-pred-25-rokmi-ano-gulasu-nie-ceresniam (дата обращения: 18.12.2020).

${ }_{10}$ Výsledky volieb rok 1992. Vol'by a referendá. Štatistický úrad Slovenskej republiky [Электронный pecypc]. URL: https://volby.statistics.sk/nrsr/snr1992/volby92s/pph92.htm (дата обращения: 20.12.2020). 
Третьи по счету парламентские выборы на плюральной основе в 1994 г. стали первыми выборами в Национальный совет Словакии в статусе уже независимой республики. Основной линией электорального разграничения могла стать необходимость в достижении социально-экономической стабильности для проведения эффективных постсочиалистических реформ. Главным политическим актером остается премьер-министр В. Мечияр и возглавляемая им партия ДЗДС, которая в избирательной коалиции с «Крестьянской партией Словакии»-КПС (Rol'nícka strana Slovenska, RSS) побеждает на этих выборах. В итоге получилось так, что реализацию структурных реформ в десятилетие постсоциализма словаки доверили одному из самых видных политиков-популистов на постсоциалистическом пространстве. При этом сам В. Мечияр не скрывает своего положительного отношения к популистским призывам, подчеркивая, что популизм является средством отношений политика с собственным народом [15, p. 184]. Коалиция ДЗДС - КПС побеждает, получив 34,96 \% поддержки. Более-менее идентичный уровень электоральной поддержки коалиции зафиксирован как в г. Братиславе $(25,44 \%)$, так и в Восточнословацком крае $(28,71 \%)^{11}$. Поэтому электоральное разграничение между западом и востоком страны снова не подтвердилось.

Парламентские выборы 1998 г. стали одними из самых судьбоносных для современной Словакии. Основной электоральной линией разграничения могла стать политическая борьба между сторонниками консервативного правительства В. Мечияра и полиидеологической «Словачкой демократической коалицичей»-CДК (Slovenská demokratická koalícia, SDK) ${ }^{12}$. Многие исследователи современного партогенеза в Словакии называют указанную линию разграничения «мечиаризм - антимечиаризм» [16, s. 78]. Это политическое противостояние стало фактическим выбором словаков между традиционной моделью постсоциализма и проевропейским развитием страны. Особенно формат этой политической конфронтации и общественного раскола наблюдался после провалившегося референдума относительно перспектив Словакии на вступление в НАТО в 1997 г. [17]. Аномальное для современной Словакии электоральное участие в районе 84,0 \% избирателей засвидетельствовало фактический дуализм в электоральной поддержке, ведь ДЗДС получило ровно 27,0 \%, тогда как СДК 26,33 \% голосов. Вместе с тем отмечаем, что электоральное разграничение между западом и востоком подтвердилось, ведь разница в полученных голосах между ДЗДС и СДК в Братиславском крае была более чем вдвое (СДК получила 43,11 \%,

${ }^{11}$ Podiel platných hlasov pre politické strany. Vol'by do NR SR 1994. Vol'by a referendá. Štatistický úrad Slovenskej republiky [Электронный peсурc]. URL: https://volby.statistics.sk/nrsr/nrsr1994/slov/ volby22a.htm (дата обращения: 12.12.2020).

12 Указанная антимечиаровская коалиция была по-настоящему полиидеологической, поскольку объединяла пять политических партий разнообразного идеологического направления. Следует согласиться с утверждением словацкого исследователя Д. Лешки в том, что СДК интегрировала правые и левые политические силы центра, которые ориентировались на либеральные ценности (Leška D. Hlavné etapy formovania systému politických strán na Slovensku po roku 1989 // Sociológia. 2013. Vol. 45, issue 1. S. 71-88). 
а ДЗДС - 20,3 \%); в Прешовскоим крае зафиксирован минимальный электоральный разрыв: СДК поддержали почти треть избирателей (30,52 \%), а ДЗДС заручилось поддержкой между третью и четвертью избирателей $(27,89 \%)^{13}$.

Следующие парламентские выборы 2002 г. закрепили внешнеполитический европейский выбор Словакии и определили стратегические приоритеты в развитии страны. Перед новым правительством, которое должно было быть сформировано по результатам выборов, стояла самая главная задача - успешно интегрировать Словакию в НАТО и Европейский союз. Эти задачи существенно осложнялись сразу несколькими факторами: провалом «НАТОвского референдума» 1997 г., отсутствием общественного единства в вопросах евроатлантической интеграции и возможным реваншем консервативных сил во главе с В. Мечияром. Следует отметить динамику общественного мнения в вопросах евроинтеграции. По состоянию на 2002 г., по данным Евробарометра, граждан, которые положительно относятся к членству страны в Европейском союзе, в Словакии насчитывалось подавляющее большинство - 58 \%; почти треть словаков (30 \%) находились в категории нейтральных; откровенными евроскептиками с негативным отношением к членству Словакии в Европейском союзе оставались всего 5 \% граждан ${ }^{14}$. Поэтому в год очередных парламентских выборов в Словакии еще достаточно большое количество граждан не определились с поддержкой вступления в Европейский союз, и будущая власть должна была успешно завершить реформы по евроинтеграции. Еще одним тестом словаков на «европейскость» должен был стать референдум о вступлении в Европейский союз. Здесь также заметно существенное расхождение в обществе, поскольку, по данным Евробарометра, в 2002 г. 69 \% словаков на референдуме проголосовали бы за вступление Словакии в Европейский союз, 11 - голосовали бы против, 8 \% - скорее всего не пришли бы на референдум ${ }^{15}$. В то же время референдум, который состоялся в мае 2003 г., показал следующие результаты: за вступление Словакии в Европейский союз проголосовали 92,46 \%, тогда как против - всего 6,20 \% (1,33\% бюллетеней признаны недействительными). В разрезе регионов также заметно единство словаков в вопросе вступления в Европейский союз: в Братиславском крае за вступление проголосовали 95,15 \%, в Прешовском крае - 91,16 \% ${ }^{16}$. За Правительством оставалась только реализация позитивного отношения словаков к вступлению в Европейский союз в практической плоскости.

${ }^{13}$ Parlamentné vol'by 1998 na Slovensku. VýsledkyVolieb.sk - Výsledky volieb na Slovensku [Электронный ресурc]. URL: https://www.vysledkyvolieb.sk/kraje/5-presovsky-kraj/parlamentnevolby/1998/vysledky (дата обращения: 20.12.2020).

${ }^{14}$ Candidate Countries Eurobarometer 2002. First Results. European Commission Directorate General Press and Communication Public Opinion Analysis [Электронный ресурc]. P. 3. URL: https:// ec.europa.eu/commfrontoffice/publicopinion/archives/cceb/2002/cceb_2002_highlights_en.pdf (дата обращения: 09.12.2020).

${ }^{15}$ Там же. Р. 6.

${ }^{16}$ Referendum 2003. Výsledky hlasovania oprávnených občanov v referende. Štatistický úrad Slovenskej republiky [Электронный ресурc]. URL: https://volby.statistics.sk/ref/ref2003/webdata/sk/ menu.htm (дата обращения: 28.12.2020). 
Согласно сложной внутриполитической ситуации, обусловленной процедурами вступления страны в Европейский союз, парламентские выборы в 2002 г. также стали судьбоносными. Основными электоральными линиями разграничения могли стать вступление Словакии в НАТО и Европейский союз, а также минимизация политического реванша В. Мечияра. Непосредственно накануне выборов сформировались три основных политических игрока. Первым по уровню избирательной поддержки оставался В. Мечияр и его партия «Движение за демократическую Словакию», второй силой считался сформированный на базе СДК «Словацкий демократический и христианский союз» - СДХС (Slovenská demokratická a krest’anská únia, SDKÚ) M. Дзуринды. Третьей силой накануне выборов стал главный политический игрок будущих лет - партия «Курс» (Smer), которая задекларировала «альтернативный путь» развития Словакии, а ее глава Р. Фицо определил себя как «лидер оппозиции» [18]. Избирательная явка хотя и существенно снизилась по сравнению с предыдущими выборами (-14 \%), но все равно была высокой и закрепилась на уровне 70 \%. ДЗДС смогли победить на выборах, но получили незначительные для себя 19,50 \% голосов, тогда как СДХС отстал всего на несколько процентов $(15,09 \%)^{17}$. По итогам выборов на региональном уровне подтвердилось электоральное разграничение между западом и востоком страны: в Братиславском крае с результатом 32,24 \% побеждает проевропейский СДХС, вторыми стало ДЗДС - 13,40 \%; в Прешовском крае, наоборот, первым становится ДЗДС с 19,28 \% голосов, а вторым - СДХС $(14,94 \%)^{18}$.

Важно, что после долгих лет политической борьбы с наследием постсоциализма и выбора оптимальной стратегии евроинтеграции в словацком политикуме сформировались традиционные идеологические противостояния. Основным электоральным разграничением могла стать политическая борьба между левоцентристами и правоцентристами. Поскольку опасность мечияровского реванша была фактически минимизирована ${ }^{19}$, партия «Курс» (Smer) существенно укрепляет свои позиции, постепенно превращаясь в партию-лидера, модифицируются христианские демократы - СДХС ${ }^{20}$. В 2006 г. была зафиксирована самая низкая избирательная явка на парламентских выборах. Первопричиной ее снижения до 54,67 \% стала усталость словаков от процедур волеизъявления, так как за достаточно короткий отрезок времени (три

${ }^{17}$ Platné hlasy odovzdané pre politické strany. Vol’by do Národnej rady Slovenskej republiky 2002. Vol'by a referendá. Štatistický úrad Slovenskej republiky [Электронный pecypc]. URL: https://volby. statistics.sk/nrsr/nrsr2002/webdata/slov/graf/grafl.htm (дата обращения: 12.12.2020).

${ }^{18}$ Parlamentné vol'by 2002 na Slovensku. VýsledkyVolieb.sk - Výsledky volieb na Slovensku [Электронный ресурc]. URL: https://www.vysledkyvolieb.sk/kraje/5-presovsky-kraj/parlamentnevolby/2002/vysledky (дата обращения: 20.12.2020).

${ }^{19}$ По итогам выборов безоговорочный лидер 1990-х гг. ДЗДС в коалиции с «Народной партией» - НП (L’udová strana, L'S) получило незначительную поддержку - всего 8,79 \% (в расчете на количество депутатских мандатов это была только десятая часть - 15 депутатов из 150 общего состава Национального совета).

${ }^{20}$ В выборах участвует коалиция СДХС - Демократическая партия (СДХС - ДП). 
года) избиратель мог принимать участие в четырех кампаниях: 2003 г. - референдум о вступлении в Европейский союз, 2004 г. - выборы Президента и первые выборы в Европейский парламент, 2005 г. - региональные выборы. Победу на выборах 2006 г. празднует социально ориентированная национально-популистская партия «Курс» (Smer) [19], которая получила почти треть голосов избирателей $(29,14$ \%). На региональном уровне подтверждается электоральное разграничение, поскольку в Братиславском крае победу празднуют правоцентристы СДХС - ДП (36,05 \%), вторыми стала левоцентристская партия «Курс» (Smer) (21,42\%); в Прешовском крае победил «Курс» (Smer) $(35,44 \%)$, тогда как коалиция СДХС - ДП стала второй $(17,93$ \%). Несмотря на разграничение, необходимо отметить постепенную стабилизацию политико-партийного пространства в Словакии, что было вызвано необходимостью проведения кардинальных внутриполитических реформ и «привыканием» Словакии к евроатлантическим структурам. В таких условиях влиятельные политические партии начинают искать своего избирателя, используя не угрозы возвращения мечияризма или запугивание ядерной войной после вступления в НАТО, а обещания проведения прагматической социальной политики. Последняя избирательная стратегия была интенсивно эксплуатируема Р. Фицо, что в итоге привело к его первому министерскому кабинету.

Парламентские выборы в 2010 г. не добавили политической стабильности в Словакии, а, наоборот, из-за нестабильного правительства И. Радичовой (2010-2012 гг.) обеспечили некоторую хаотичность политической системы. Из предыдущих парламентских выборов сохранилось электоральное разграничение, которое заключалось в политической борьбе между левоиентристами и правоцентристами. За годы первого премьерства Р. Фицо (2006-2010 гг.) партии «Курс» (Smer) удалось существенно укрепить свои политические позиции, а ДЗДС из бывшего лидера окончательно превратилось в пережиток постсоциалистического прошлого, которое не может преодолеть 5-процентный проходной барьер. Еще одним влиятельным игроком на политической арене становится партия «Свобода и солидарность»-СиС (Sloboda a Solidarita, SaS), евроскептическая по своему идеологическому содержанию и ориентированная на приоритеты современной западноевропейской либеральной политики: уменьшение социальных привилегий политиков, укрепление основ гражданского общества, легализация легких наркотиков, финансовые свободы и фискальная децентрализация и т. д. [20]. Избирательная явка хотя немного и улучшилась, но все равно оставалась одной из самых низких за всю современную историю Словакии (58,83 \%). В итоге партия «Курс» (Smer) увеличила свой предыдущий результат до 34,79 \% и заняла первое место. Второй с результатом в два раза меньше $(15,42 \%)$ стала коалиция СДХС - ДП. На региональном уровне подтверждается электоральное разграничение: в Братиславском крае с незначительным перевесом побеждает коалиция СДХС - ДП (27,58 \%), «Курс» (Smer) занимает второе место 
$(25,11 \%)$. В Прешовском крае безоговорочную победу одерживает «Курс» (Smer) (41,68 \%), на втором месте расположились консерваторы - «Христианско-демократическое движение» - ХДД (Krest'anskodemokratické hnutie, $\mathrm{KDH})(14,97 \%)$, а коалиция СДХС - ДП оказалась только на третьей позиции $(13,66 \%)^{21}$. Дальнейшие недоразумения между Р. Фицо и другими политическими силами, неудачный поиск политических компромиссов между левоцентристами и правоцентристами и общая нестабильность правительства приводят к досрочным парламентским выборам в 2012 г.

Выборы в Национальный совет в 2012 г. также сопровождались политическими скандалами. Речь идет о «деле Гориллы», которое привело к одной из самых жестких избирательных кампаний в современной Словакии. Несмотря на стремительное падение доверия словацкого избирателя к ведущим политикам, нашлись деятели, которые на фоне антикоррупционной волны смогли получить значительные политические дивиденды. В первую очередь, это социал-демократическая партия «Курс» (Smer), которая в итоге победила и получила рекордные для себя 44,41 \% голосов, а также популисты - партия «Обычные люди» (OLaNO), которые с 8,55 \% стали третьими ${ }^{22}$. Очевидно, такие результаты и фактический провал коалиции СДХС - ДП (только 6,09 \%) стали возможными из-за обещаний лидера «Обычных людей» (OLaNO) И. Матовича и опытного политика Р. Фицо эффективно бороться с коррупционными проявлениями в политике ${ }^{23}$. Основное электоральное разграничение могло быть вызвано антикоррупционным популизмом в политике. Избирательная явка составила 59,11\%, а результаты выборов позволили Р. Фицо создать монопартийное правительство. На региональном уровне электоральное разграничение не подтвердилось: партия «Курс» (Smer) побеждает как в Братиславском $(32,62 \%)$, так и в Прешовском крае $(50,52 \%)^{24}$.

Следующие парламентские выборы 2016 г. также характеризовались активной электоральной борьбой. Главными вопросами, вокруг которых составлялись предвыборные программы, были миграционные вопросы и связанные с ними «угрозы» для Словакии [21]. Основным электоральным

${ }^{21}$ Parlamentné vol'by 2010 na Slovensku. VýsledkyVolieb.sk - Výsledky volieb na Slovensku [Электронный pecypc]. URL: https://www.vysledkyvolieb.sk/kraje/5-presovsky-kraj/parlamentnevolby/2010/vysledky (дата обращения: 20.12.2020).

22 Počet a podiel platných hlasov odovzdaných pre politické strany. Vol'by do Národnej rady Slovenskej republiky 2012. Vol'by a referendá. Štatistický úrad Slovenskej republiky [Электронный pecypc]. URL: https://volby.statistics.sk/nrsr/nrsr2012/sr/tab3.jsp@lang=sk.htm (дата обращения: 12.12.2020).

${ }_{23}$ В контексте «дела Гориллы» надо отметить определенные моменты. На самом деле, Р. Фицо был одним из участников этого коррупционного скандала, что не помешало ему победить на предстоящих парламентских выборах. Другой политик-популист И. Матович после победы на выборах 2020 г. пытается подтвердить свой статус бескомпромиссного борца с коррупцией, в частности, в начале декабря 2020 г. был арестован активный участник «дела Гориллы», один из самых богатых людей Словакии Я. Гачщак.

${ }^{24}$ Počet a podiel platných hlasov odovzdaných pre politické strany. URL: https://volby.statistics.sk/ nrsr/nrsr2012/sr/tab3.jsp@lang=sk.htm. 
разграничением могло стать политическое противостояние между левым и правым электоратом вокруг вопросов миграционной политики и размещения бежениеев в Словакии. В итоге партии «Курс» (Smer) удалось удержать лидирующие позиции, несмотря на серьезную и неожиданную конкуренцию со стороны СиС и партии «Обычные люди» (OL'aNO). Параллельно сформировалось значительное представительство в парламенте правых и ультраправых популистов в составе партии «Котлеба - Народная партия «Наша Словакия» - НПНС (Kotlebovci - L’udová strana Naše Slovensko, LSNS), «Словацкой национальной партии» - СНП (Slovenská národná strana, SNS) и партии «Мы - семья» (Sme Rodina) Б. Коллара, которые вместе заняли 40 из 150 мест в Национальном совете ${ }^{25}$. Избирательная явка осталась на прежнем уровне и составила 59,82 \%. Победителями снова стала партия «Курс» (Smer), которая существенно ухудшила свой предыдущий результат и получила всего $28,28 \%{ }^{26}$. На региональном уровне подтверждается электоральное разграничение: в Братиславском крае побеждает СиС с результатом в 24,46 \%, «Курс» оказался на втором месте с результатом 19,39 \%; в Прешовском крае лидируют популисты - «Курс» получает 32,99 \%, на втором месте с 12,09 \% расположились «Обычные люди» ${ }^{27}$. Результаты парламентских выборов существенно фрагментируют политико-партийное пространство Словакии и активизируют ультраправые политические движения, которые постепенно превратились во влиятельных парламентских игроков.

Последние на сегодня парламентские выборы состоялись в 2020 г. Определяющее влияние на их результаты имело резонансное убийство журналиста Я. Куцака и его невесты в феврале 2018 г. $^{28}$. Обвинения главы правительства Р. Фицо в его причастности к коррупционным схемам, которые привели к убийству журналиста, в конечном итоге также привели к отставке всего правительства. Логично, что электоральным разграничением могло стать политическое противостояние «Фиц̧о - антиФиц̧о»" 29 . Как часто бывает, глубокий политический кризис, вызванный падением уровня гражданского доверия к политикам и поиск «новых лиц» в политике, принесли достаточно неожиданные результаты. Учитывая тяжелый контекст выборов и стремление к мгновенным

${ }^{25}$ Počet a podiel platných hlasov odovzdaných pre politické subjekty. Vol'by do Národnej rady Slovenskej republiky 2016. Vol'by a referendá. Statistický úrad Slovenskej republiky [Электронный pecypc]. URL: https://volby.statistics.sk/nrsr/nrsr2016/sk/data02.html (дата обращения: 12.12.2020).

${ }^{26}$ Там же.

${ }^{27}$ Parlamentné vol'by 2016 na Slovensku. VýsledkyVolieb.sk - Výsledky volieb na Slovensku [Электронный ресурc]. URL: https://www.vysledkyvolieb.sk/kraje/5-presovsky-kraj/parlamentnevolby/2016/vysledky (дата обращения: 20.12.2020).

${ }_{28}$ Cuprik R., Kapitán P., Filo J. Investigatívneho reportéra Jána Kuciaka zavraždili, zrejme v súvislosti s jeho prácou [Электронный pecypc] // SME.sk. 26. feb. 2018. URL: https://domov.sme. sk/c/20768704/reportera-jana-kuciak-zavrazdili-v-jeho-dome.html (дата обращения: 15.01.2021).

29 Здесь мы не можем не вспомнить аналогичное по своей политической сути противостояние накануне парламентских выборов 1998 г. - «мечияризм - антимечияризм». 
изменениям, избирательная явка была наивысшей $(65,8$ \%), начиная с 2006 г.30. Прогнозируемо партия «Курс» (Smer) во главе с новым лидером М. Пеллигрини проигрывает избирательную гонку, но все-таки, заняв второе место, получает поддержку в 18,29 \% голосов. Победителями выборов стали популисты - партия «Обычные люди» (OL'aNO) во главе с И. Матовичем, - которые заручились поддержкой 25,02 \% избирателей ${ }^{31}$. С другой стороны, высокий результат партии «Обычные люди» был логичным благодаря активной популистской предвыборной кампании, основанной на борьбе с коррумпированными политиками Словакии ${ }^{32}$. На региональном уровне электоральное разграничение подтвердилось, хотя сложилась достаточно спорная ситуация. В Братиславском крае безапелляционную победу одерживает избирательная коалиция в составе OLaNO NOVA - KÚ - ZMENA ZDOLA (26,32 \%), «Курс» демонстрирует только четвертый результат (12,04 \%), расположившись после либералов - «Коалиции «Прогрессивная Словакия»-BMEСТЕ - Гражданская демократия» (Progresívne Slovensko - SPOLU - Občianska demokracia) (14,24 \%) и СиС (12,26 \%). В Прешовском крае также побеждает коалиция во главе с «Обычными людьми» (OL'aNO), продемонстрировав почти аналогичный результат (25,63\%); второй становится партия «Курс» (Smer), отстав от лидера чуть более чем на четыре процента $(20,99 \%)^{33}$. Это свидетельствует не только о прочных позициях партии «Курс» (Smer) на востоке страны, но и о весомой электоральной поддержке правых популистов, поскольку ультраправые НПНС получили 8,50 \%, а правые популисты «Мы - семья» $-8,39 \%{ }^{34}$. В Словакии сформировалось коалиционное правительство во главе с И. Матовичем, который должен был не только вернуть словакам доверие к политикам, но и вести эффективное антикризисное управление во время первой и второй волны пандемии коронавируса.

Фрагментация политико-партийного пространства Словакии в соответствии со знаковыми электоральными разграничениями в регионах. Анализ хода и результатов парламентских выборов в Словакии после периода социализма позволил отметить два знаковых электоральных разграничения: а) «мечиаризм - антимечиаризм» 1998 г.; б) «Фицо - антиФицо» 2020 г. Эти разграничения имеют как схожие, так и различные социально-политические основы. С одной стороны, речь идет о выборе более демократичной линии в руководстве страны, что особенно актуально по отношению к популистской твердой линии руководства В. Мечияра. С другой стороны, в 1998 г.

${ }^{30}$ Platné hlasy odovzdané pre politické subjekty podl'a územného členenia. Vol'by do Národnej rady Slovenskej republiky 2020. Vol'by a referendá. Štatistický úrad Slovenskej republiky [Электронный pecypc]. URL: https://volby.statistics.sk/nrsr/nrsr2020/sk/data02.html (дата обращения: 12.12.2020).

${ }_{31}^{31}$ Там же.

${ }^{32}$ Matovič predstavil priority, chce presadit' to, čo rozhodnú l'udia [Электронный pecypc] // SME. sk. 1. feb. 2020. URL: https://domov.sme.sk/c/22315929/volby-2020-matovic-predstavil-programolano.html (дата обращения: 06.01.2021).

${ }_{33}$ Platné hlasy odovzdané pre politické subjekty podl’a územného členenia. URL: https://volby. statistics.sk/nrsr/nrsr2020/sk/data02.html.

${ }^{34}$ Там же. 
Словакия также делала судьбоносный для себя выбор: или интеграция (вступление в недалекой перспективе) в евроатлантическое пространство, или пролонгация переходного периода постсоциализма. В 2020 г. перед словаками не ставился настолько судьбоносный выбор, но, в то же время, речь шла о преодолении значительного уровня гражданского недоверия к отечественным политикам. Высокий уровень недоверия старым политикам предложил словацкому избирателю популистскую альтернативу в лице И. Матовича, что должно было «перезагрузить» всю систему власти.

Проанализируем два названных ключевых электоральных разграничения не только по отношению к Братиславскому и Прешовскому краям, но и в масштабе всей Словакии.

Электоральное разграничение «мечиаризм - антимечиаризм» (1998 г.). Напомним, что центральным в то время было межпартийное противостояние ДЗДС В. Мечияра и полиидеологической СДК М. Дзуринды. Ниже рассмотрим региональную политико-партийную фрагментацию Словацкой Республики (рис. 1).

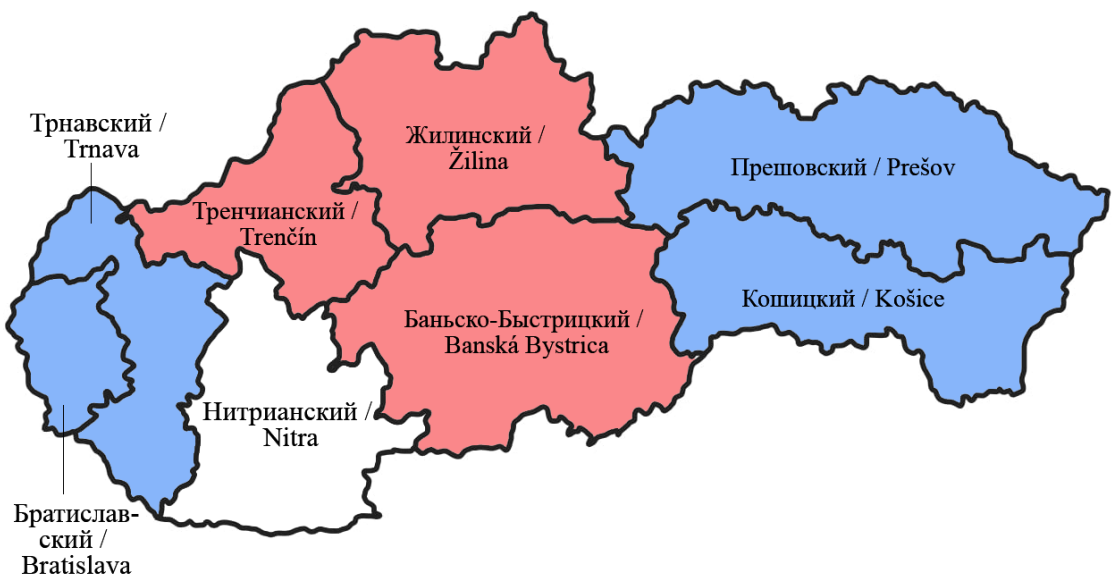

Р и с. 1. Фрагментация Словацкой Республики по электоральному разграничению «мечияризм - антимечияризм»

F i g. 1. Fragmentation of the Slovak Republic according to the electoral cleavage of "Meciarism - anti-Meciarism"

Из рисунка 1 заметна четкая политико-географическая фрагментация: крайняя Словакия на востоке (Прешовский и Кошицкий края) и западе (Братиславский и Трнавский края) поддержала оппозиционных к мичияровской

35 Маркировка краев в Словацкой Республике в соответствии с цветами в партийной символике: синим цветом обозначены края, в которых побеждает СДК; красным - края, где побеждает ДЗДС; белым - Нитрианский край, в котором первой стала «Партия венгерского меньшинства». 
политической линии «демократических коалициантов» - СДК; центральная Словакия, которая на самом деле объединяет частично юг (Бансько-Быстрицкий край) и север страны (Жилинский и Тренчианский края), была единодушна в поддержке консерваторов - ДЗДС. Несколько девиантным на этом электоральном фоне выглядит юго-западный Нитрианский край, в котором победу празднуют венгры из «Партии венгерского сообщества»- ПВС (Strana mad’arskej koalície, SMK) (26,39\%), а ДЗДС (23,4 \%) и СДК (21,1\%) заняли соответственно второе и третье места ${ }^{36}$. Однако это только на первый взгляд, поскольку венгерское меньшинство в Словакии имеет наибольшее представительство именно в Нитрианском крае ${ }^{37}$, поэтому там традиционно прочной является электоральная поддержка венгерских партий.

Электоральное разграничение «Фицо - антиФицуо (2020 г.) - еще одно знаковое политическое противостояние, которое состоялось на последних на сегодня парламентских выборах. Речь идет, с одной стороны, о поиске словацким избирателем новых лиц в политике, а с другой - о приверженности части электората к «коррумпированной политике» бывшего премьер-министра Р. Фицо (рис. 2).

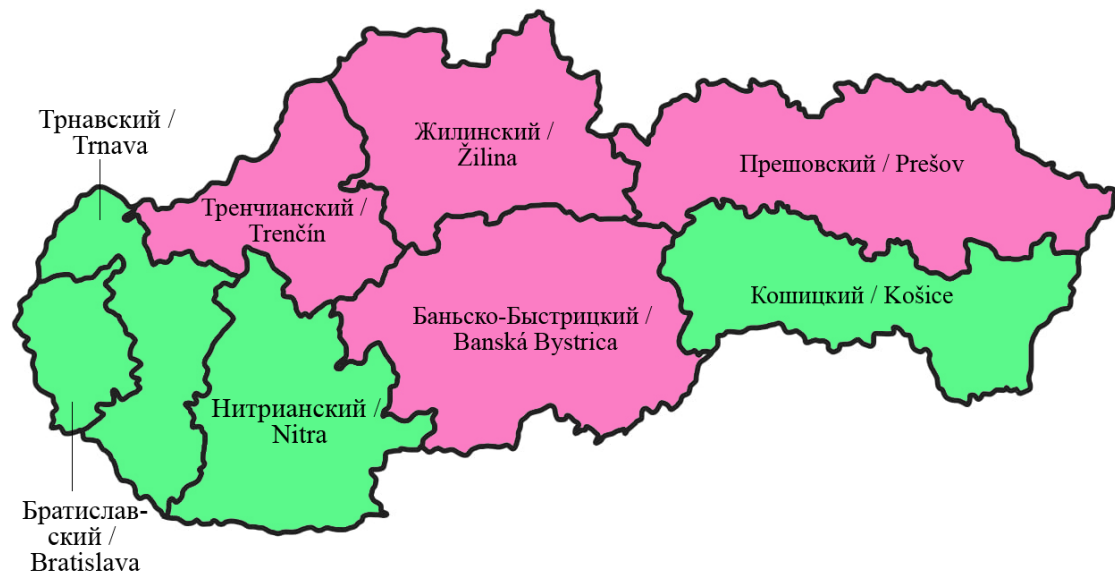

Р и с. 2. Фрагментация Словацкой Республики по электоральному разграничению «Фицо - антиФицо» ${ }^{38}$

F i g. 2. Fragmentation of the Slovak Republic according to the electoral cleavage "Fico - anti-Fico"

\footnotetext{
${ }^{36}$ Parlamentné vol'by 1998 na Slovensku. URL: https://www.vysledkyvolieb.sk/kraje/5-presovsky$\mathrm{kraj} /$ parlamentne-volby/1998/vysledky.

${ }^{37}$ Splnomocnenc vlády pre národnostné menšiny. Úrad vlády Slovenskej republiky [Электронный pecypc]. URL: https://www.narodnostnemensiny.gov.sk (дата обращения: 15.12.2020).

${ }^{38}$ Маркировка краев в Словацкой Республике в соответствии с цветами в партийной символике: зеленый - края, в которых побеждает коалиция во главе с партией «Обычные люди»; розовый - края, в которых электоральный разрыв между партиями «Обычные люди» и «Курс» составляет менее 5 \%.
} 
При рассмотрении политико-партийной трансформации Словацкой Республики по результатам парламентских выборов нужно отметить несколько определяющих характеристик. Мейнстримовая антиправительственная партия «Обычные люди» (OL'aNO ) побеждает во всех без исключения краях. Поэтому с первого взгляда на уровне регионов электоральные разграничения не заметны. Однако такое положение является скорее электоральной тенденцией, чем свидетельством общего проигрыша партии «Курс» (Smer) в регионах. По результатам выборов мы сознательно разделили регионы на две простые группы: 1) типичные, в которых разрыв между партиями «Обычные люди» и «Курс» составил более 5 \% (минимальный проходной барьер в Национальный совет); 2) нетипичные, в которых электоральный разрыв между партиями составил менее $5 \%$. По сравнению с электоральным разграничением «мечияризм - антимечияризм» (1998 г.) закономерности фрагментации остались неизменными: центр Словакии (Тренчианский, Жилинский и Бансько-Быстрицкий края) близок к менее либеральной политической риторике социальной направленности партии «Курс», тогда как запад (Братиславский и Трнавский края) и восток (Кошицкий край) страны в большей степени голосовали за либеральных популистов - партию «Обычные люди».

Конечно, необходимо отметить некоторые отличия, например, Прешовский край был отнесен к нетипичным только благодаря численному превышению нормативных $5 \%$ на $0,36 \%{ }^{39}$. В свою очередь, в Нитрианском крае на фоне партий «Обычные люди» (OLaNO) и «Курс» (Smer) свои голоса недобрала традиционно сильная ПВС, заняв только третье место $(12,31 \%)^{40}$. Напомним, что по результатам выборов в независимой Словацкой Республике, начиная с 1994 г., венгерские партии впервые в 2020 г. не преодолели проходного барьера и остались вне парламента.

Обсуждение и заключение. В ходе проведенного исследования мы определили основные линии электорального разграничения на уровне регионов современной Словакии.

Количественные показатели избирательной явки подтвердили первоочередной интерес словацких избирателей к национальному уровню политики, а именно к избранию парламента Национального совета. Ведь в среднем участие в парламентских выборах принимают около 70 \% избирателей. Учитывая социально-экономическую дифференциацию между столичным Братиславским регионом и восточным Прешовским краем, результаты парламентских выборов рассматривались именно в этой географической плоскости. Каждый общественно-политический раскол находил свое отражение в уровне электоральной поддержки конкретной политической силы.

${ }^{39}$ Коалицию во главе с партией «Обычные люди» поддержали 25,63 \% избирателей, «Курс» заручился поддержкой 20,99\%. Фактический электоральный разрыв между политическими силами составил $4,64 \%$.

${ }^{40}$ Platné hlasy odovzdané pre politické subjekty podl'a územného členenia. URL: https://volby. statistics.sk/nrsr/nrsr2020/sk/data02.html. 
Общественно-политические расколы формировались в соответствии с историческими требованиями и текущей политической конъюнктурой в стране: начало политического плюрализма (1990 г.), фактор независимости словаков (1992 г.), необходимость стабилизации (1994 г.), конфронтация между адептами постсоциализма и евроатлантизма (1998 и 2002 гг.), традиционное политическое противостояние между правым и левым политическим центром (2006 и 2010 гг.), антикоррупционная и антиэмигрантская популистская риторика (2012 и 2016 гг.), поиск «новой политики» (2020 г.).

Из десяти парламентских выборов электоральные разграничения подтвердились в шести случаях (в 1998, 2002, 2006, 2010, 2016 и 2020 гг.). Заметен незначительный перевес электоральных разграничений, хотя и несущественный. Наиболее единогласным было голосование на выборах в период постсоциализма 1990-х гг. и на парламентских выборах 2012 г., когда на волне борьбы с политической коррупцией наибольшие дивиденды получил Р. Фицо. С момента стабилизации партийной системы и начала традиционных идеологических противостояний электоральные разграничения на региональном уровне фактически не подтверждаются.

Наконец, наиболее значимыми для современной Словакии стали общественно-политические расколы «мечиаризм - антимечиаризм» (1998 г.) и «Фицо - антиФицо» (2020 г.). Они были обозначены электоральными разграничениями, формируя трехмерную фрагментацию регионов Словакии: 1) запад, лояльный к либеральным политическим силам; 2) центр, в большей степени ориентированный на консерваторов и с отдельными симпатиями к партиям праворадикального толка (например, Бансько-Быстрицкий край); 3) восток, в котором равномерной остается электоральная поддержка консерваторовпопулистов и либерал-демократов, хотя с небольшим преимуществом вторых. Еще одним фактором электоральной фрагментации современной Словакии остается значение венгерских политических партий в Нитрианском крае («Mocт» (Most-Híd), ПВC). Хотя последние парламентские выборы в этом контексте выглядят девиантными, поскольку венгерские партии впервые не прошли в парламент, а правые радикалы также не получили значительной электоральной поддержки, за исключением партии одиозного М. Котлебы.

Практическое значение исследования заключается в разработке прогнозов и рекомендаций по преодолению общественно-политических расколов внутри страны и уменьшению электоральных расстояний между регионами (в контексте минимизации веса праворадикальных сил в политической системе и снижения уровня политического популизма по стране). Дальнейшие научные исследования могут быть связаны с комплексным анализом электоральной фрагментации регионов постсоциалистических и постсоветских стран в соответствии с имеющимися общественно-политическими расколами. 


\section{REFERENCES}

1. Elff M. Social Structure and Electoral Behavior in Comparative Perspective: The Decline of Social Cleavages in Western Europe Revisited. Perspectives on Politics. 2007; 5(2):277-294. (In Eng.) DOI: https://doi.org/10.1017/S1537592707070788

2. Whitefield S. Political Cleavages and Post-Communist Politics. Annual Review of Political Science. 2002; 5:181-200. (In Eng.) DOI: https://doi.org/10.1146/annurev.polisci.5.112601.144242

3. Redžić E., Everett J. Cleavages in the Post-Communist Countries of Europe: A Review. Politics in Central Europe. 2020; 16(1):231-258. (In Eng.) DOI: https://doi. org/10.2478/pce-2020-0011

4. Cleavages, Parties, and Voters: Studies from Bulgaria, the Czech Republic, Hungary, Poland, and Romania / eds. by A. Rommele, K. Lawson, G. Karasimeonov. London: Praeger; 1999. Available at: https://www.amazon.com/Cleavages-Parties-Voters-BulgariaPolitical/dp/0275955893 (accessed 12.12.2020). (In Eng.).

5. Bakke E., Sitter N. Why do Parties Fail? Cleavages, Government Fatigue and Electoral Failure in the Czech Republic, Slovakia and Hungary 1992-2012. East European Politics. 2013; 29(2):208-225. (In Eng.) DOI: https://doi.org/10.1080/21599165.2013.786702

6. Szabó B., Tátrai P. Regional and Social Cleavages in the Slovak Elections after the Change of the Regime. Geografický časopis = Geographical Journal. 2016; 68(3):195-212. Available at: https://www.researchgate.net/publication/309670733_Regional_and_social_cleavages_in_the_ Slovak elections after the change of the regime (accessed 12.12. 2020$)$. (In Eng.)

7. Plešivčák M. Ideology, Cleavages, and Voting Behaviour in 2009 and 2013 Regional Elections in Slovakia. Acta Universitatis Carolinae. Geographica. 2017; 52(1):90-105. (In Eng.) DOI: https://doi.org/10.14712/23361980.2017.8

8. Martinkovič M. Regionálne vol’by do VÚC ako prejav krízy funkčnosti strán v Slovenskom straníckom systéme. Politologická analýza regionálnych volieb 2017 na Slovensku / editori I. Dudinská, M. Cirner, G. Székely. Prešov: Vydavatel’stvo Prešovskej university; 2018. p. 39-49. (In Slovak)

9. Plešivčák M. Position of Slovak Regions in the Light of Electoral Support for Parties in the Parliamentary Elections Held Between 2002 and 2010. Geografický časopis = Geographical Journal. 2011; 63(3):227-251. Available at: https:/www.researchgate.net/publication/262680504_Postavenie_regionov_Slovenska_z_hladiska_uzemi_volebnej_podpory_politickych_stran_- $\mathbf{v}$ parlamentnych_volbach_v_rokoch_2002-2010_Position_of_Slovak_Regions_in_the_Light_of_Electoral_Support_for_Parties_in (accessed 12.12.2020). (In Slovak)

10. Szöllös J. Rēgional Stability of Electoral Support of Selected Political Parties in Slovakia, 1990-1998. Geografický časopis = Geographical Journal. 2000; 52(3):243-267. Available at: https://www.sav.sk/?lang=sk\&doc=journal-list\&part=article response page \&journal article no=7512 (accessed 12.12.2020). (In Slovak)

11. Szöllös J. Regions of Electoral Support of Chosen Political Parties in Parliamentary Elections 1998, 2002 and 2006. Geografická revue = Geographical Review. 2006; 2(2):650-669. Available at: https://www.fpv.umb.sk/geo-revue/publikovane-cisla/2006/2-2006/ (accessed 12.12.2020). (In Slovak)

12. Kislyakov M. Station and Trends of Development of Regional Electoral Process. Regionologiya = Regionology. 2012; (1):40-44. Available at: https://regionsar.ru/ru/node/864 (accessed 12.12.2020). (In Russ., abstract in Eng.)

13. Chikhladze N., Chikhladze L. Modern Challenges in Establishing Financial Base of Local Self-Governance in Georgia. Bulletin of the Georgian National Academy of Sci- 
ences. 2018; 12(2):176-183. Available at: http://science.org.ge/bnas/t12-n2/27_Chikhladze. pdf (accessed 12.12.2020). (In Eng.)

14. Baer J. Boxing and Politics in Slovakia: 'Meciarism' Roots, Theory, Practice. Democratization. 2001; 8(2):97-116. (In Eng.) DOI: https://doi.org/10.1080/714000200

15. Deegan-Krause K. Populism, Democracy, and Nationalism in Slovakia. In: Populism in Europe and the Americas: Threat or Corrective for Democracy? / eds. C. Mudde, C. Rovira Kaltwasser. Cambridge: Cambridge University Press; 2012. p. 182-204. (In Eng.) DOI: https://doi.org/10.1017/CBO9781139152365.010

16. Leška D. The Main Phases of the Formation of System of Political Parties in Slovakia After 1989. Sociológia = Slovak Sociological Review. 2013; 45(1):71-88. Available at: https:// www.sav.sk/journals/uploads/03041249Leška - OK.pdf (accessed 12.12.2020). (In Slovak)

17. Belko M., Kopeček L. Referendum in Theory and Practice: The History of the Slovak Referendums and their Consequences. Středoevropské politické studie = Central European Political Studies Review. 2003; 5(2-3). Available at: https://journals.muni.cz/cepsr/ article/view/3946/5319 (accessed 12.11.2020). (In Eng.)

18. Marušiak J. Political Party „SMER“ - in berween „Pragmatism“ and Social Democracy. Středoevropské politické studie = Central European Political Studies Review. 2006; 8(1):19-55. Available at: https://journals.muni.cz/cepsr/article/view/4162/6069 (accessed 12.11.2020). (In Czech)

19. Mesežnikov G., Gyárfášová O. National Populism in Slovakia. Bratislava; 2006. Available at: https://www.ivo.sk/5555/en/news/national-populism-in-slovakia-\%E2\%80\%93-newpublication-by-ivo (accessed 12.11.2020). (In Eng.)

20. Spac P. Anti-Europeanism and Euroscepticism in Slovakia. European Integration and New Anti-Europeanism II / eds. P. Moreau, B. Wassenberg. Stuttgart: Franz Steiner Verlag; 2016. p. 163-180. Available at: https://www.muni.cz/en/research/publications/1351241 (accessed 12.11.2020). (In Eng.)

21. Rybář M., Spáč P., Voda P., Nemčok M. Po stopách politického zemětřesení: Parlamentní volby na Slovensku v roce 2016. Brno: Centrum pro studium demokracie a kultury a Masarykova univerzita; 2017. Available at: https:/www.muni.cz/vyzkum/publikace/1402718 (accessed 12.11.2020). (In Czech)

Поступила 09.02.2021; одобрена после рецензирования 05.03.2021; принята к публикации 14.03.2021.

Submitted 09.02.2021; approved after reviewing 05.03.2021; accepted for publication 14.03.2021.

\section{Об авторе:}

Гайданка Евгений Иванович, доцент кафедры политологии Трнавского университета (918 43, Словакия, г. Трнава, ул. Горнопоточная, д. 23), кандидат политических наук, ORCID: https://orcid.org/0000-0001-8112-2090, Researcher ID: M-7335-2018, Scopus ID: 57218488947, yevheniy.haydanka@truni.sk

Автор прочитал и одобрил окончательный вариант рукописи.

About the author:

Yevheniy I. Haydanka, Associate Professor, Department of Political Science, Trnava University (23 Hornopotočná St., Trnava 918 43, Slovakia), Cand. Sci. (Political Science), ORCID: https://orcid.org/0000-0001-8112-2090, Researcher ID: M-7335-2018, Scopus ID: 57218488947, yevheniy.haydanka@truni.sk

The author has read and approved the final version of the manuscript. 


\section{ЭКОНОМИКА И УПРАВЛЕНИЕ НАРОДНЫМ ХОЗЯЙСТВОМ / ЕСОNOMICS AND MANAGEMENT OF NATIONAL ECONOMY}

УДК 338.2

DOI: $10.15507 / 2413-1407.115 .029 .202102 .250-282$

http://regionsar.ru

Оригинальная статья / Original article

ISSN 2587-8549 (Print)

ISSN 2413-1407 (Online)

\section{Инструменты межрегионального взаимодействия в системе государственного управления}

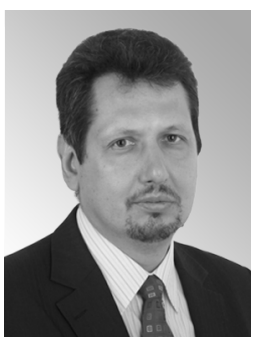

В. В. Климанов

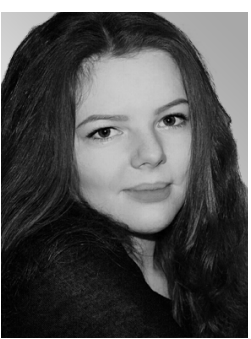

С. М. Казакова

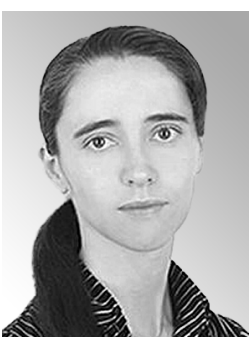

В. А. Яговкина

ФГБОУ ВО «Российская академия народного хозяйства и государственной службы при Президенте Российской Федерации»

$$
\text { (2. Москва, Российская Федерачия), }
$$

Введение. Развитие современной России характеризуется высокой степенью дифференциации в уровне социально-экономического развития субъектов Федерации, одним из инструментов преодоления которой является межрегиональное сотрудничество. Несмотря на возникающие новые формы такого сотрудничества, его потенциал остается недооцененным. Цель статьи - по результатам проведенного исследования проанализировать существующие и перспективные формы сотрудничества регионов России.

Материалы и методы. Исследование строится на структурно-содержательном анализе нормативных правовых актов федерального и регионального уровней, а также документов стратегического планирования, различных форм бюджетной отчетности, двусторонних и многосторонних соглашений между субъектами Российской Федерации на предмет выявления различных направлений, инструментов и механизмов обеспечения межрегионального сотрудничества.

Результаты исследования. Авторами подробно рассматриваются инструменты межрегионального сотрудничества, предполагающие непосредственное финансовое участие региональных органов государственной власти или хозяйствующих субъектов. Определяются роль и перспективы горизонтальных субсидий и бюджетных кредитов, предоставляемых одним регионом другому, дается их нормативно-правовое

(C) Климанов В. В., Казакова С. М., Яговкина В. А., 2021 Контент доступен под лицензией Creative Commons Attribution 4.0 License. This work is licensed under a Creative Commons Attribution 4.0 License. 
обоснование, производится финансовая оценка и анализируется выявленная практика. В части осуществления государственных закупок у поставщиков из других регионов интерпретируются оценки степени замкнутости/открытости субъектов Федерации.

Обсуждение и заключение. Подтверждается идея, что межрегиональное взаимодействие в России по-прежнему недостаточно развито, не находит своего законодательного и научно-методического обоснования; также оцениваются перспективы дальнейшего развития межрегионального сотрудничества в России, предлагается ряд мер по его совершенствованию. Результаты исследования могут быть использованы в интересах органов власти для совершенствования системы регулирования различных механизмов сотрудничества регионов, а также для развития научного потенциала в данной сфере.

Ключевые слова: регион, субъект Российской Федерации, межрегиональное сотрудничество, межрегиональное взаимодействие, интеграция, «горизонтальная» субсидия, «горизонтальный» кредит, государственная закупка

Авторы заявляют об отсутствии конфликта интересов.

Финансирование. Статья подготовлена в рамках реализации государственного задания РАНХиГС на 2021 г.

Для ичитирования: Климанов, В. В. Инструменты межрегионального взаимодействия в системе государственного управления / В. В. Климанов, С. М. Казакова, В. А. Яговкина. - DOI 10.15507/2413-1407.115.029.202102.250-282 // Регионология. - 2021. T. 29, № 2. - C. 250-282.

\title{
Tools of Interregional Cooperation in the Public Administration System
}

\author{
V. V. Klimanov*, S. M. Kazakova, V. A. Yagovkina \\ Russian Presidential Academy of National Economy and Public Administration \\ (Moscow, Russian Federation), \\ *vvk@irof.ru
}

Introduction. The development of modern Russia is characterized by a high degree of differentiation in the level of socio-economic development of the constituent entities of the Russian Federation. Interregional cooperation is one of the tools to overcome this differentiation. Although new forms of such cooperation have been emerging, its potential remains underestimated. The purpose of the study is to analyze the existing and prospective forms of cooperation between the regions of Russia.

Materials and Methods. The study based on a structural and substantive analysis of regulatory legal acts of the federal and regional levels, as well as on strategic planning documents, various forms of budget reporting, bilateral and multilateral agreements between the constituent entities of the Russian Federation aimed at identifying various areas, tools and mechanisms for ensuring interregional cooperation.

Results. The authors have considered the tools of interregional cooperation that involve direct financial participation of regional authorities or economic entities. The role and prospects of horizontal subsidies and budget loans provided by one region to another have been identified, their legal and regulatory justification has been given; a financial assessment has been made, and the identified practices have been analyzed. In terms of the implementation of public procurement from suppliers based in other regions, the authors have estimated the degree of how closed or open the constituent entities of the Russian Federation are. 
Discussion and Conclusion. The authors have confirmed the idea that interregional cooperation in Russia is still underdeveloped and lacks legislative and scientificmethodological justification. The authors also assess the prospects for further development of interregional cooperation in Russia and suggest a number of measures to promote it. The results of the study can be used in the interests of the authorities to improve the system of regulation of various mechanisms of regional cooperation, as well as to develop the scientific potential in this area.

Keywords: region, constituent entity of the Russian Federation, interregional cooperation, interregional interaction, integration, horizontal subsidy, horizontal loan, public procurement

The authors declare that there is no conflict of interest.

Funding. The article was done as part of the implementation of the government assignment to RANEPA for 2021.

For citation: Klimanov V.V., Kazakova S.M., Yagovkina V.A. Tools of Interregional Cooperation in the Public Administration System. Regionology = Russian Journal of Regional Studies. 2021; 29(2):250-282. DOI: https://doi.org/10.15507/24131407.115.029.202102.250-282

Введение. Интеграционные процессы происходят повсеместно, как на уровне стран, так и на уровне отдельных регионов и макрорегионов. С одной стороны, интеграция - это естественный процесс формирования устойчивых экономических связей на основе разделения факторов производства, сопровождающийся взаимной корректировкой и дополнением определенных отраслей, предприятий и экономических регионов и ведущий к формированию целостной экономической системы. С другой стороны, интеграция представляет собой управляемый процесс, который требует целенаправленной деятельности взаимодействующих субъектов для координации их взаимоотношений.

В странах мира центральное правительство в контексте решения задач регионального развития выполняет ключевые функции, связанные, во-первых, с обеспечением равного доступа к конституционно гарантированным правам, во-вторых, с использованием и учетом индивидуальных особенностей и преимуществ регионов с целью создания условий для их устойчивого роста и, в-третьих, с обеспечением межрегиональной интеграции, в необходимых случаях выступая «арбитром» при решении споров между отдельными административно-территориальными единицами. Последнее должно быть особенно актуально в России - стране с максимальным в мировой практике количеством административно-территориальных единиц первого порядка (регионов) с большими различиями по показателям социально-экономического развития.

Таким образом, цель статьи - на основе анализа нормативных правовых актов и практики применения существующих инструментов межрегионального сотрудничества выявить перспективы развития регионов России.

Обзор литературы. Экономическое развитие регионов невозможно только за счет имеющихся у них внутренних ресурсов. Межрегиональный обмен ресурсами и готовой продукцией является ключевым фактором экономического 
роста регионов и повышения их конкурентоспособности. Такое взаимодействие способствует и сокращению межрегиональной дифференциации внутри единой страны ${ }^{1}[1]$, что создает условия для обеспечения конституционно установленных принципов равного доступа граждан к общественным благам. Межрегиональное сотрудничество является также одним из факторов устойчивости (резилиентности) региона к внешним шоковым воздействиям [2].

Важность межрегионального взаимодействия и его концептуальное обоснование подтверждаются теориями конкуренции, интеграции, международной торговли и отраслевой специализации, хотя их положения не всегда касаются непосредственно взаимодействия пространственных элементов внутри системы национальной экономики.

Согласно теории сравнительных преимуществ Д. Рикардо, торговля двух стран взаимовыгодна при определенном соотношении цен производимого ими продукта ${ }^{2}$. В эмпирических исследованиях доказывается, что ограничение международной торговли приводит к снижению темпов экономического роста и общему ухудшению социально-экономического положения страны [3] и, наоборот, торговля может способствовать ускорению экономического роста ${ }^{3}$. Это же в полной мере относится и к регионам внутри страны.

Теория эффекта масштаба П. Кругмана гласит, что международная торговля выгодна с точки зрения экономии в использовании факторов производства и приводит к увеличению рынков сбыта, улучшению структуры потребления и общему повышению уровня благосостояния населения [4].

В теории конкурентных преимуществ М. Портера говорится о том, что хозяйствующий субъект, которым может выступать и регион, повышает конкурентоспособность и создает конкурентные преимущества за счет эффекта масштаба, достигаемого выстраиваемыми экономическими связями, а также за счет налаживания рынков сбыта, появляющихся в результате взаимодействия ${ }^{4}$.

Научные работы, посвященные анализу процессов межрегиональной интеграции, изучают в основном интеграционные процессы транснационального уровня [5] и практически не затрагивают уровень национальный ${ }^{5}$, что и определяет актуальность исследования механизмов межрегиональной интеграции [6].

Межрегиональная интеграция считается более легкореализуемой, нежели международная, ввиду отсутствия различных политико-экономических и административных барьеров ${ }^{6}$. Однако в зарубежной регионалистике имеется

${ }^{1}$ Лукин Е. В., Ускова Т. В. Межрегиональное экономическое сотрудничество: состояние, проблемы, перспективы. Вологда: ИСЭРТ РАН, 2016. 148 с.

${ }^{2}$ Блауг М. Экономическая мысль в ретроспективе. М.: Дело, 1994. 688 с.

${ }^{3}$ Markesen J. R., Maskus K. E., Kaempfer W. H. International Trade: Theory and Evidence. NBER Working Paper Series. 1995. No. 4940.

${ }^{4}$ Портер М. Конкурентное преимущество: как достичь высокого результата и обеспечить его устойчивость. М.: Альпина Бизнес Букс, 2005. 878 с.

${ }^{5}$ Factors of Regional Specialization in the Context of Interregional Integration. 33rd IBIMA Conference. 10-11 April 2019, Granada, Spain. 2019.

${ }^{6}$ Гранберг А. Г. Региональная экономика: учеб. для вузов. М.: Изд. дом ГУ ВШЭ, 2006. 493 с. 
и большое число работ, посвященных изучению процессов межрегионального и муниципального взаимодействия в контексте осуществления приграничного сотрудничества [7-9].

Н. Данфорд отмечает, что взаимовыгодное международное и межрегиональное сотрудничество является составляющей инклюзивного роста и развития [10]. В. Лью с соавторами пишут о необходимости развития процесса интеграции между городскими и сельскими территориями для сокращения уровня бедности сельского населения [11]. А. Р. Пунтильяно связывает межрегиональную интеграцию с необходимостью «слабых» регионов обеспечить свое присутствие на международном рынке путем территориальной экспансии, компенсируя недостаток контроля над ресурсами [12]. На основе анализа интеграционных процессов даже разработана так называемая теория кристаллизации, которая показывает, как межтерриториальное сотрудничество на низких уровнях организации может поддерживать социальный порядок на более высоком уровне государственного управления [13].

Изначально в исследованиях регионального развития преобладал системный подход, который предполагал взаимодействие регионов как подсистем системы более высокого порядка. Так, Д. Нир утверждает, что регионы следует рассматривать как открытые системы, в которых явления анализируются не как отдельные элементы, а как часть системы ${ }^{7}$. При этом система характеризуется наличием постоянных связей между ее компонентами. Регион одновременно является и системой, и компонентом более крупной пространственной единицы ${ }^{8}$. С системной точки зрения региональные границы определяются степенью взаимосвязей и процессов, действующих в регионе.

Финансовая специфика межрегионального взаимодействия освящается в литературе крайне редко. По мнению А. А. Кофанова, сбалансированная налогово-бюджетная система сокращает уровень изъятий для эффективных участников межрегионального взаимодействия [14]. Кроме того, достижение высокого уровня межрегионального взаимодействия способствует повышению бюджетной самостоятельности регионов, которая в настоящий момент остается невысокой 9 .

В отечественной литературе популярны работы, посвященные взаимодействию субъектов Федерации в составе одного федерального округа или макрорегиона [15; 16]. В таких публикациях, как правило, существенное внимание уделяется вопросам необходимости соблюдения межрегиональных соглашений о сотрудничестве, а также формирования стратегий развития макрорегионов. При этом отмечается, что одним из ключевых ограничений

${ }^{7}$ Nir D. Regional Geography Considered from the System's Approach // Geoforum. 1987. No. 18. Pp. 187-202.

${ }^{8}$ Климанов В. В. Региональное развитие и региональные системы в России. М.: Эдиториал УРCC, 2003. $293 \mathrm{c}$.

${ }^{9}$ Шеркунов С. А. Использование зарубежного опыта межрегионального взаимодействия в российских условиях // Россия: тенденции и перспективы развития: материалы XV Международ. науч. конф. 2015. С. 709-711. 
реализации таких документов является отсутствие в региональных бюджетах необходимых финансовых средств для реализации программ, направленных на развитие межрегионального сотрудничества или же подразумевающих использование межрегионального сотрудничества в качестве ключевого инструмента реализации данных программ. Поэтому реальные перспективы развития такого сотрудничества в настоящее время существуют лишь у регионов с высокой долей бюджетной обеспеченности [17].

Нельзя не отметить исследования, посвященные выявлению места межрегионального сотрудничества в документах стратегического планирования. Так, например, межрегиональное взаимодействие рассматривается в рамках возможности достижения эффективной реализации государственных программ развития регионов [1]. В работе О. Бакуменко и соавторов проводится текстуальный анализ стратегий социально-экономического развития Северо-Западного федерального округа с выявлением в них упоминаний случаев межрегиональной кооперации [18].

Таким образом, современная научная литература изучает в основном теоретические основы, особенности и формы интеграции национальных и транснациональных единиц и редко затрагивает вопросы кооперации на субнациональном уровне, а число отечественных эмпирических исследований, оценивающих уровень сотрудничества регионов, весьма невелико.

Материалы и методы. Методологический подход к оценке текущего состояния и перспектив развития межрегионального сотрудничества основывается на инвентаризации и систематизации существующих инструментов межрегионального сотрудничества.

Поиск возможных форм сотрудничества осуществлялся посредством анализа нормативных правовых актов Российской Федерации (как ключевых кодексов, так и отраслевого законодательства), документов стратегического планирования, в том числе стратегий развития федеральных округов, а также законодательных актов субъектов Федерации.

Были проанализированы все имеющиеся в справочно-правовой системе «КонсультантПлюс» соглашения субъектов Федерации о сотрудничестве, а также законы о региональных бюджетах на предмет выявления различных механизмов взаимодействия, в том числе финансовых.

Более детально были изучены отчеты об исполнении бюджета г. Москвы за 2015-2018 гг. в части предоставления субсидий бюджетам других субъектов Федерации. В результате анализа были определены основные направления и объемы финансирования.

На основе проведенного анализа авторами были сделаны выводы о степени развитости межрегионального сотрудничества в России, а также оценены перспективы его дальнейшего развития. Были предложены рекомендации по совершенствованию механизмов межрегионального сотрудничества, касающиеся изменений в законодательстве, а также выработки различных мер стимулирования со стороны Российской Федерации. 
Результаты исследования. На практике выявляются формы межрегионального двустороннего и многостороннего сотрудничества, которое может осуществляться как между органами государственной власти субъектов Российской Федерации, так и между хозяйствующими субъектами, базирующимися в разных регионах. Последнее, включающее и межрегиональную торговлю, осуществление инвестиций компаниями в регионы не своего базирования - тема отдельного исследования, лежащего в стороне от анализа взаимодействия собственно регионов как публично-правовых образований и их органов управления.

Многостороннее сотрудничество регионов осуществляется путем участия их органов власти в ассоциативных структурах, создаваемых с целью координации взаимодействия для достижения устойчивого состояния в развитии экономики территорий. Межрегиональные ассоциации экономического взаимодействия появились еще в 1990-х гг., необходимость их создания была обусловлена разрывом экономических связей между территориями бывшего СССР наряду с высоким уровнем дифференциации социально-экономического развития регионов [19]. Максимально активная фаза в деятельности таких ассоциаций пришлась на конец 1990-х - начало 2000-х гг., но и в настоящее время функционирует шесть таких ассоциаций.

Регионы взаимодействуют и в рамках выполнения совместных задач, в том числе оказания услуг населению, например, в части организации перевозок граждан общественным транспортом ${ }^{10}$. Некоторые субъекты уже имеют нормативную основу формирования межрегиональных связей и заключения межрегиональных соглашений по различным вопросам. Так, по состоянию на сентябрь 2020 г., действующие законы, посвященные регулированию межрегиональных связей или заключению межрегиональных соглашений, имеются как минимум в 17 регионах ${ }^{11}$. Большая часть соглашений - двусторонние, однако на практике выявляются и случаи заключения многосторонних соглашений, например, между Республикой Калмыкия, Ставропольским краем, Астраханской и Ростовской областями о сотрудничестве в сфере экономики, туризма, развития физической культуры и спорта, реализации государственной политики в отношении российского казачества. Соглашения о сотрудничестве имеются в настоящее время в большинстве субъектов Федерации.

Другим направлением межрегионального сотрудничества является участие субъектов Федерации в выработке документов стратегического планирования (стратегий, программ) макрорегионов, а также схем территориального

${ }^{10}$ Об организации регулярных перевозок пассажиров и багажа автомобильным транспортом и городским наземным электрическим транспортом в Российской Федерации и о внесении изменений в отдельные законодательные акты Российской Федерации: Федеральный закон от 13.07.2015 № 220-Ф3. Здесь и далее приводится по базе правовой информации «Консультант Плюс».

${ }^{11}$ Республики Алтай, Кабардино-Балкария, Карачаево-Черкесия, Крым, Тыва, Чечня, Хабаровский край, Амурская, Воронежская, Кировская, Ленинградская, Нижегородская, Новосибирская, Свердловская, Тамбовская, Томская, Тульская области. 
планирования двух и более субъектов Федерации. Подобная практика пока также незначительна, но ее законодательное регулирование определено требованиями закона о стратегическом планировании ${ }^{12}$, Градостроительным кодексом Российской Федерации и другими законами. Положения, закрепляющие необходимость пересмотра существующих стратегий социальноэкономического развития макрорегионов, были инициированы в утвержденной в 2019 г. Стратегии пространственного развития на период до 2025 г. ${ }^{13}$.

Действующие стратегии макрорегионов, по сути - федеральных округов, часто пересекаются с федеральными и региональными стратегиями и подходят к развитию округа комплексно, но практически не учитывая межрегиональные связи. Вместе с тем стратегии признают важность межрегионального сотрудничества в контексте повышения эффективности пространственной организации экономики, связности территории и извлечения дополнительных конкурентных преимуществ за счет достижения синергетического эффекта.

Структурно-содержательный анализ формально действующих стратегий ${ }^{14}$ говорит о том, что в качестве отдельного направления политики межрегиональное сотрудничество рассматривается редко; только в стратегиях трех округов (Северо-Западного, Южного и Уральского) оно вынесено в отдельный раздел. Среди набора мероприятий (которых в среднем насчитывается по 90), отраженных в соответствующих планах по реализации стратегий, мероприятия, напрямую или косвенно связанные с развитием межрегионального сотрудничества, составляют лишь малую часть от общего числа - в среднем по три на макрорегион, а в Стратегии развития Сибирского федерального округа - и вовсе отсутствуют.

Основными направлениями межрегионального сотрудничества, обозначенными в стратегиях макрорегионов, являются реализация инфраструктурных и инвестиционных проектов, связанных с развитием скоростного пассажирского железнодорожного сообщения (Южный федеральный округ), строительством терминально-логистических комплексов (Северо-Кавказский федеральный округ), развитием автомобильных дорог и межрегиональных авиационных сетей (Приволжский федеральный округ) и др. Популярными направлениями являются также туризм (в том числе в форме межрегиональных туристических кластеров, например, Северокавказский туристический кластер, туристско-рекреационные комплексы в Центральном и Дальневосточном федеральных округах) и производственная кооперация на базе таких отраслей, как сельское хозяйство (Центральный федеральный округ)

12 О стратегическом планировании в Российской Федерации: Федеральный закон от 28.06.2014 № 172-Ф3.

${ }^{13}$ Об утверждении Стратегии пространственного развития Российской Федерации на период до 2025 года: Распоряжение Правительства Российской Федерации от 13.02.2019 № 207-р.

${ }^{14}$ Стратегии социально-экономического развития Центрального, Северо-Западного, Южного, Приволжского федеральных округов и Сибири - на период до 2020 г.; а стратегии Северо-Кавказского федерального округа, Дальнего Востока и Байкальского региона - на период до 2025 г. 
и производство строительных материалов (Северо-Западный федеральный округ). В социальной сфере реализуются совместные проекты, связанные с содействием занятости населения, в том числе в рамках создания межрегиональных центров занятости населения (в Северо-Кавказском федеральном округе), а также развитием объектов социальной инфраструктуры.

С учетом вышеизложенного участие регионов в разработке федеральных стратегий развития макрорегионов не в полной мере может считаться формой межрегионального сотрудничества. Возложение разработки таких стратегий на региональные органы власти при общем руководстве со стороны федерального центра могло бы послужить и развитию межрегионального сотрудничества [20].

Долгое время не находили своего законодательного утверждения такие формы двустороннего взаимодействия, как горизонтальные субсидии и горизонтальные бюджетные кредиты. Нормы, регламентирующие финансовое взаимодействие субъектов Федерации, появились в бюджетном законодательстве только в 2019 и 2020 гг,, о чем подробнее сказано ниже.

Косвенным доказательством наличия связей органов власти и хозяйственных структур разных регионов может выступать наличие государственных закупок, осуществляющих межрегиональную поставку товаров или выполнение работ. Несмотря на то, что оцениваемый уровень межрегионального протекционизма ${ }^{15}$ демонстрирует высокую региональную замкнутость, можно выделить перечень регионов, с которыми как можно больше субъектов Федерации стремится установить хозяйственные связи.

Согласно рейтингу регионального протекционизма Счетной палаты Российской Федерации, в 2019 г. около 2/3 всех заключенных контрактов пришлось на Москву, при этом средняя доля в поставках в каждый регион составила 14,5 \%. Санкт-Петербург также является поставщиком товаров, работ и услуг во все субъекты Федерации, однако уже со средней долей в поставках в 6,3\%. Ключевыми направлениями сотрудничества в рамках закупочной деятельности выступают также Республика Татарстан, Московская, Нижегородская и Свердловская области.

Большую роль в осуществлении закупок все же играет пространственный фактор - в основном регионы сотрудничают со своими соседями либо с субъектом Федерации, входящим в тот же федеральный округ и являющимся экономически более развитым. Наиболее «оторванным» от межрегиональной закупочной деятельности оказался Дальневосточный федеральный округ. К региональному протекционизму более склонны «слабые» регионы, больше зависящие от федерального бюджета.

Перечень форм межрегионального взаимодействия, а также механизмы взаимодействия субъектов Российской Федерации при их реализации представлены в таблице 1.

15 Рейтинг регионального протекционизма (по 44-Ф3) [Электронный ресурс] / Госрасходы. URL: https://spending.gov.ru/analytics/ratings/rating-protectionism/ (дата обращения: 01.09.2020). 


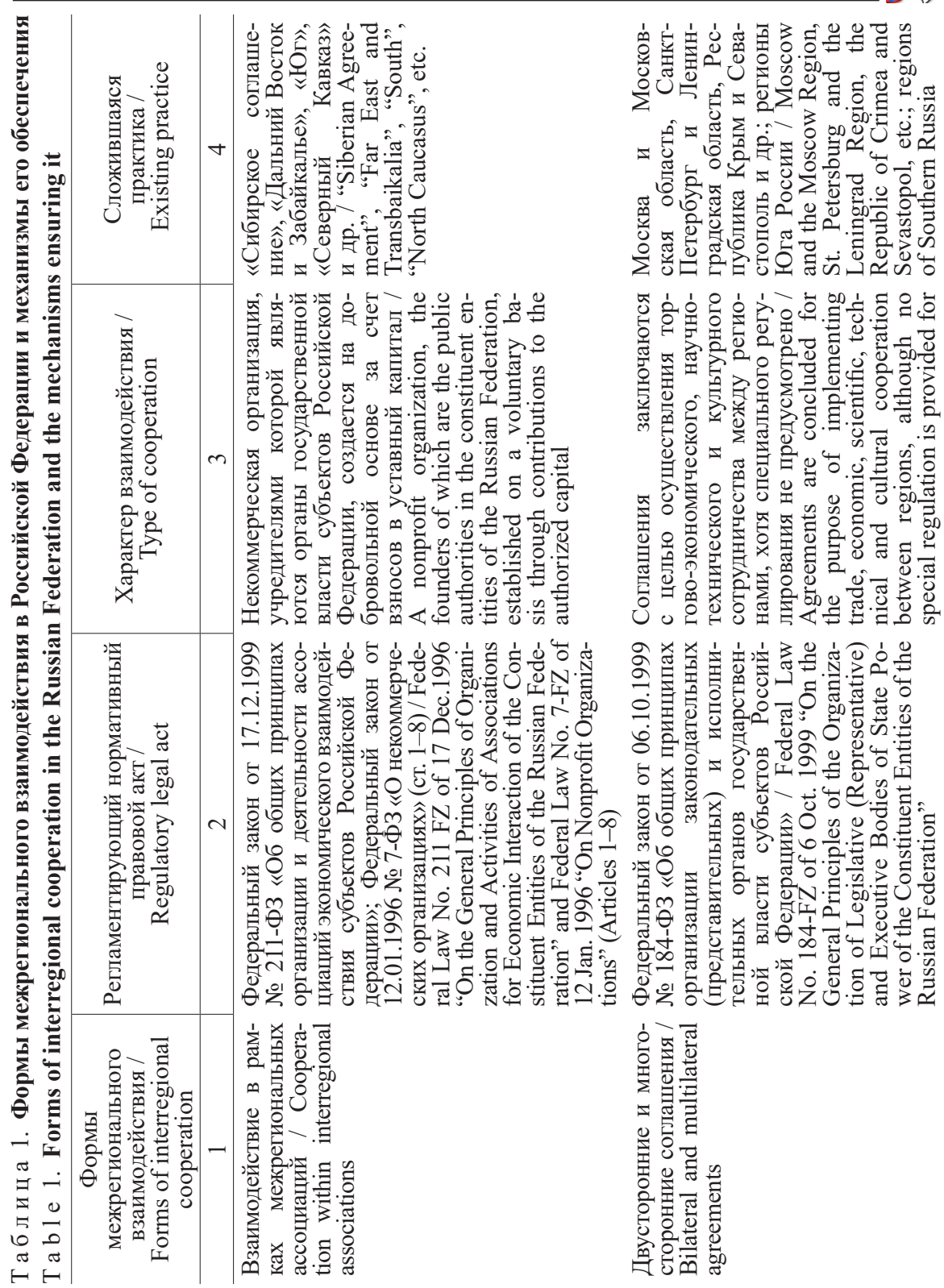




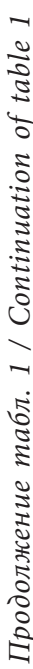

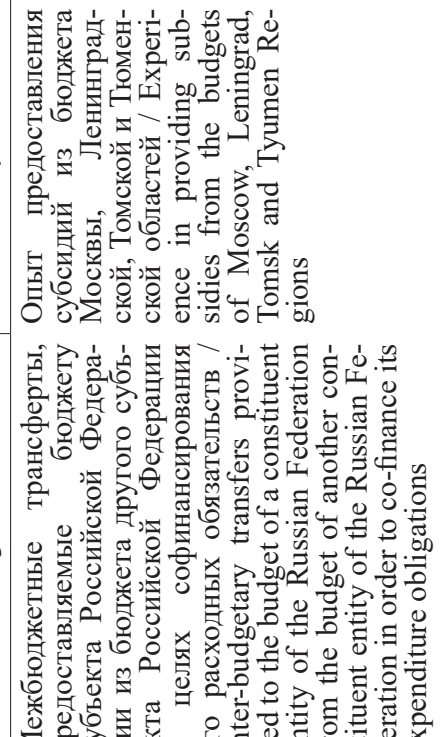

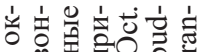

-

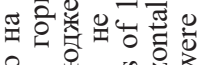

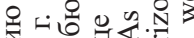

엉

잉요

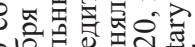

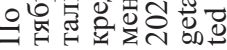

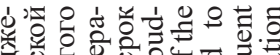

,

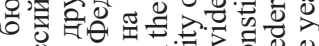

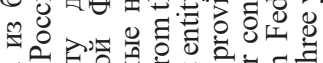

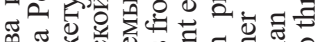

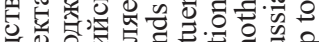

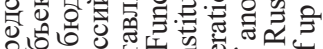

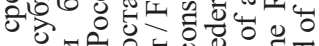

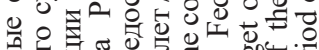

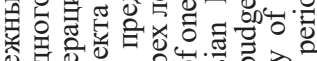

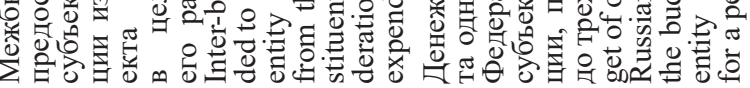

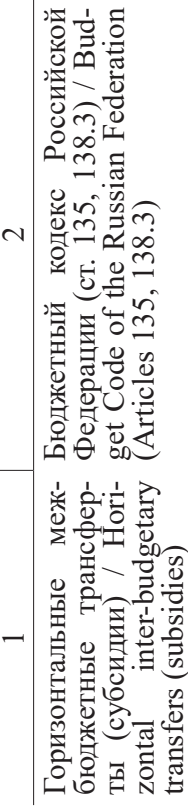

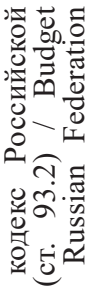

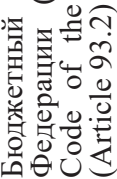

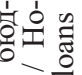

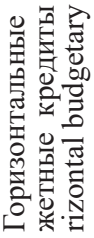




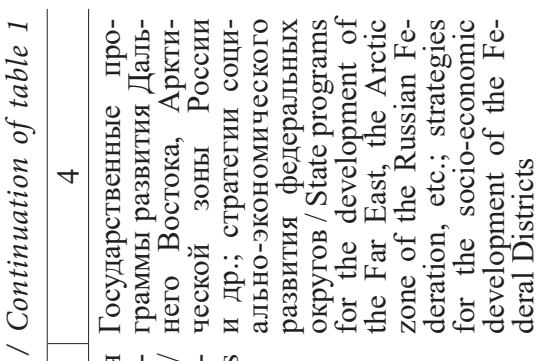

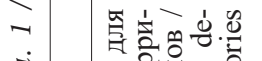 \\ 点

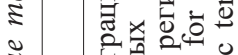 \\ 辛 \\ m $\Xi$ 运

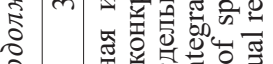

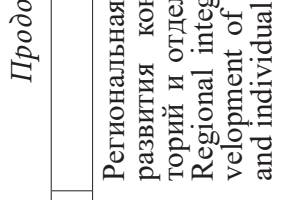

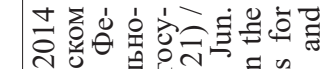

ชู.

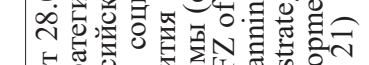

N

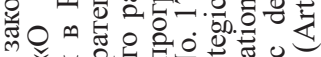

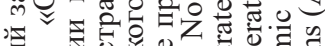

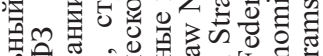

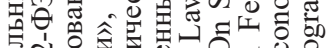

蛋

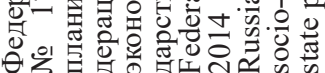

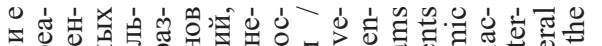

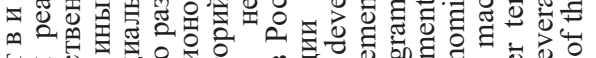

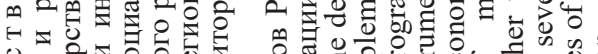

脚

-

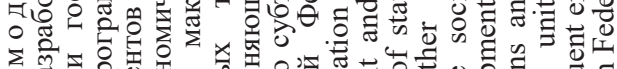

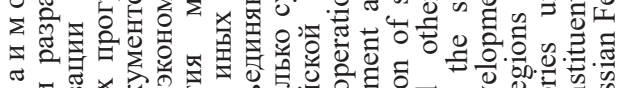

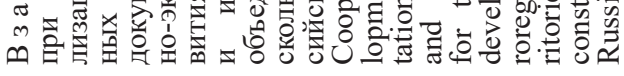

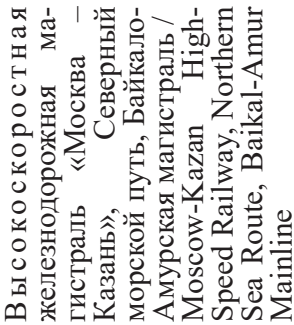

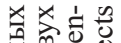

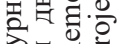

㱐递

完艺

으ㄴㅡㅡ 을

空

है के

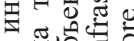

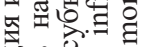

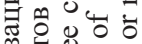

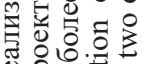

目: 志.

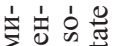

政

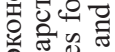

1 당뭉

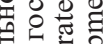

就高

焉吾

m $\sum_{0}$

$\checkmark$ :

ธ。율

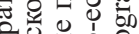

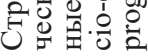

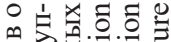

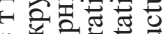

0 空司

ㄴ. 5 윰

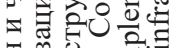

诺

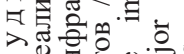

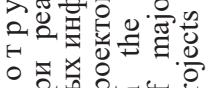

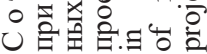




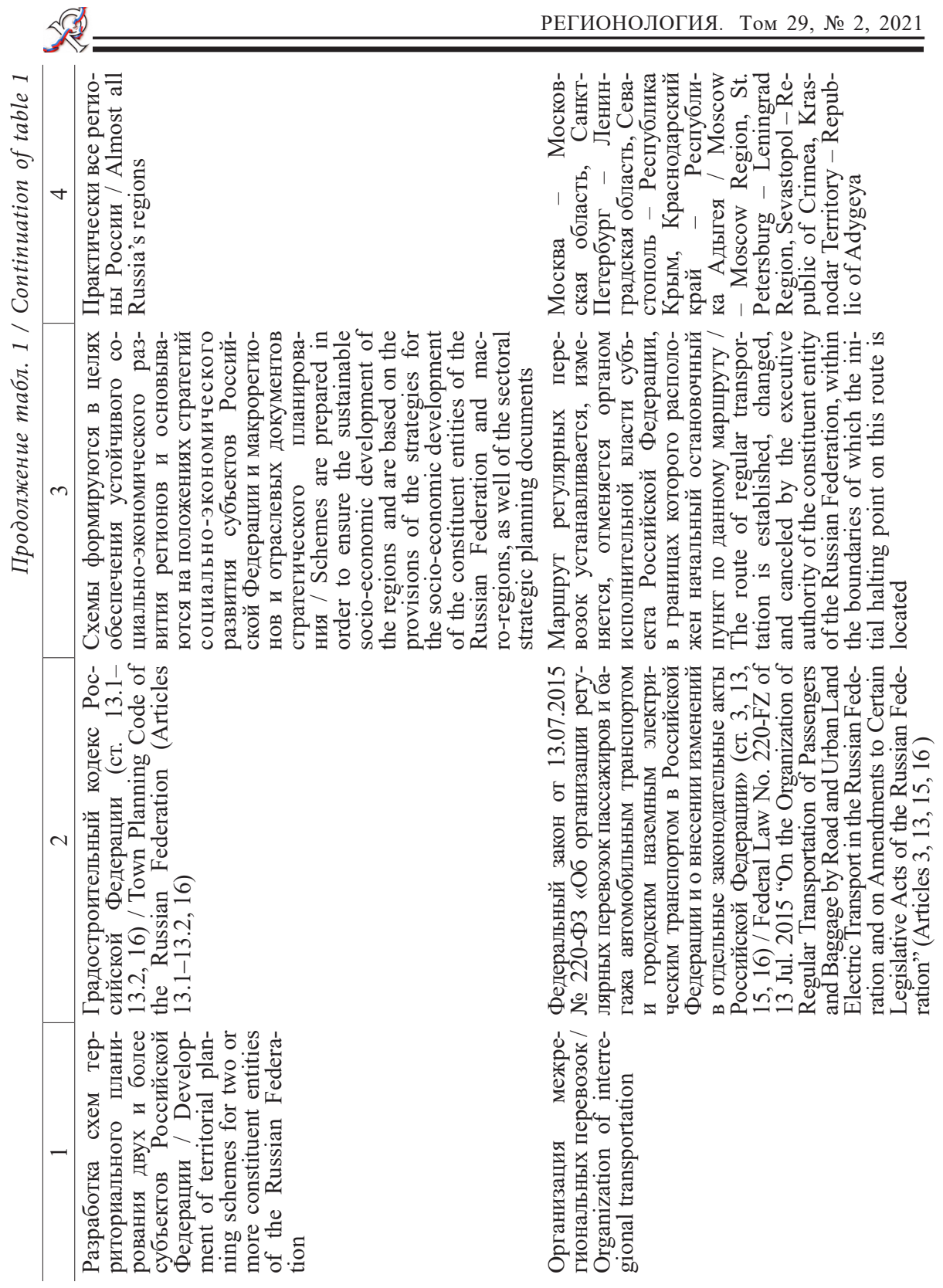




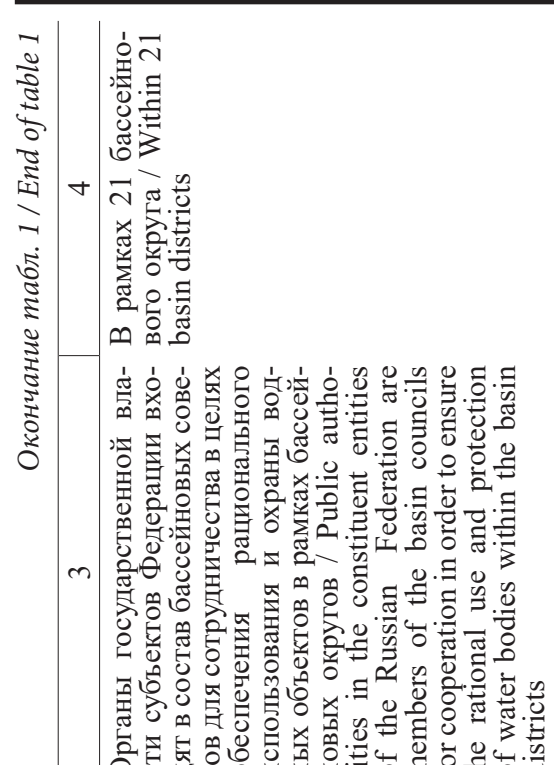

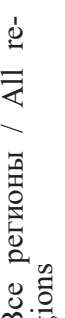

D

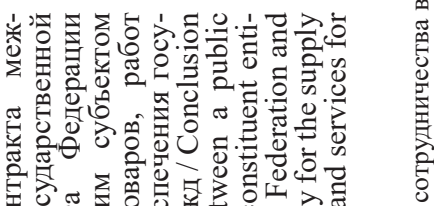

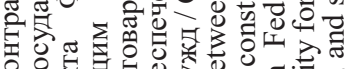

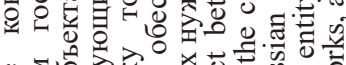

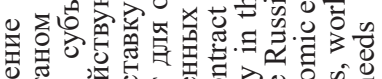

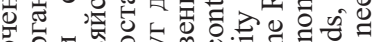

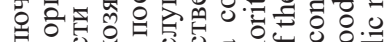

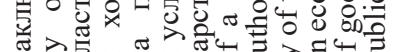
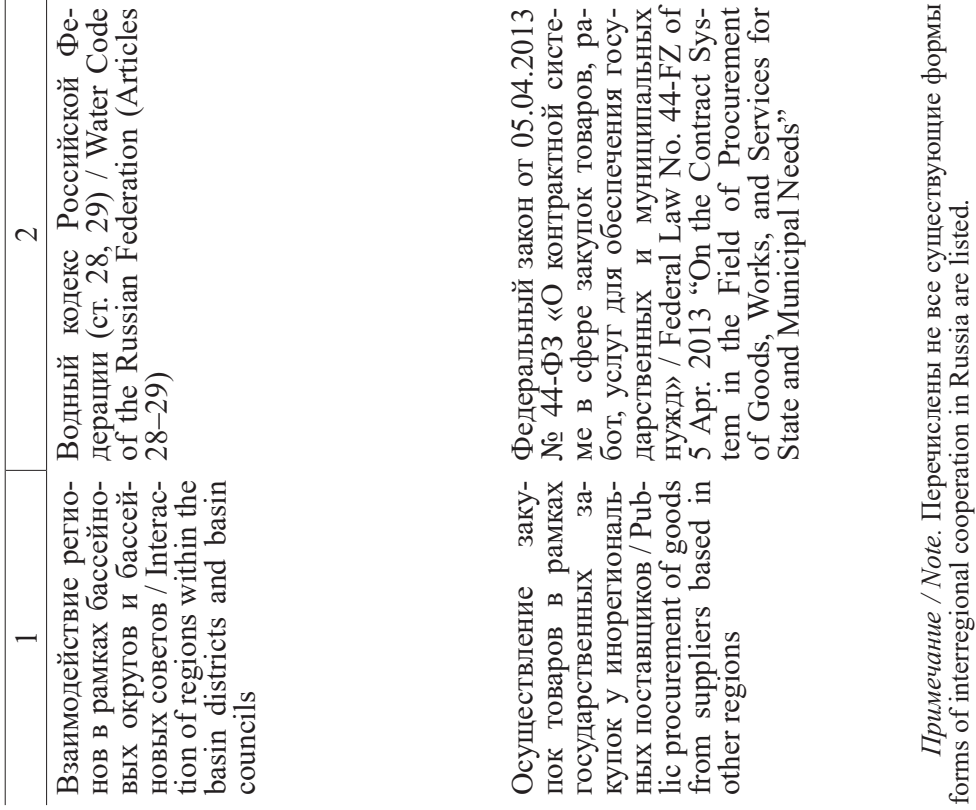
Косвенно межрегиональное взаимодействие проявляется и в рамках отраслевого законодательства, например, в водной сфере имеет место регулирование 21 бассейнового округа, охватывающего территорию нескольких субъектов Федерации или их частей. Бассейновый округ в соответствии со ст. 28 Водного кодекса Российской Федерации является основной единицей управления в области использования и охраны водных объектов. В целях обеспечения рационального использования и охраны водных объектов создаются бассейновые советы, осуществляющие разработку рекомендаций в области использования и охраны водных объектов в границах бассейнового округа.

Аналогично взаимодействие регионов осуществляется в рамках лесных зон. Однако межрегиональные отношения в сфере управления лесными объектами регламентируются только на федеральном уровне, не предусматривая особых инструментов взаимодействия между субъектами Федерации в сфере лесных отношений.

Особого внимания заслуживают новые механизмы межрегионального сотрудничества, предполагающие задействование собственных средств и инициатив субъектов Федерации - «горизонтальные» субсидии и «горизонтальные» бюджетные кредиты.

В августе 2019 г. в Бюджетный кодекс Российской Федерации были внесены изменения в целях совершенствования межбюджетных отношений, в рамках которых были впервые введены нормы, регламентирующие так называемые горизонтальные трансферты, которые могут осуществляться в форме субсидий между бюджетами субъектов Федерации и муниципальных образований ${ }^{16}$.

В целом система межбюджетных отношений в России, по оценкам российских и международных экспертов, признается достаточно эффективной [21]. Помимо прочего она направлена на сокращение межрегиональной дифференциации и основана на механизмах «вертикального» финансового выравнивания, т. е. между уровнями бюджетной системы. Уровень межрегиональной дифференциации до предоставления межбюджетных трансфертов, направленных на выравнивание бюджетной обеспеченности (дотаций), достигает десятизначных показателей для регионов. Ряд экспертов признают, что система межбюджетных отношений, включающая около 100 видов субсидий целевого назначения, только усиливает зависимость социально-экономической политики регионов от федерального центра [22].

Общее же понимание «горизонтального» выравнивания сводится к тому, что финансовые ресурсы все равно изначально аккумулируются в федеральном центре, а потом уже перераспределяются между регионами. «Горизонтальные» субсидии в общую логику федеральной политики регионального развития пока не встраиваются.

${ }^{16} \mathrm{O}$ внесении изменений в Бюджетный кодекс Российской Федерации в целях совершенствования межбюджетных отношений: Федеральный закон от 02.08.2019 № 307-Ф3. 
Несмотря на это, о необходимости выработки новых механизмов «горизонтального» выравнивания на межрегиональном уровне говорится уже несколько лет. Так, например, звучало предложение о введении на федеральном уровне «отрицательного межбюджетного трансферта» по такому же принципу, как он существует на региональном уровне, когда региональному бюджету предоставляются субсидии из местных бюджетов ${ }^{17}$. Идея перенесения механизма на федеральный уровень заключается во включении в методику расчета трансферта также индекса бюджетных расходов, что позволит учитывать большие различия в расходных потребностях между регионами [23].

Однако подобное перераспределение доходов от «богатых» регионов «бедным» носит скорее принудительный характер и дестимулирует наращивание налогового потенциала региональных бюджетов. Такая политика, реализуемая «сверху - вниз», может негативно повлиять на результат межрегионального выравнивания. В этой связи управление должно осуществляться с учетом инициатив, выдвигаемых самими объектами управления, в данном случае - регионами, поскольку любая оценка региональной экономики является неполной без рассмотрения существующей политики, инициируемой и реализуемой на разных уровнях [24]. Следовательно, межрегиональные «горизонтальные» трансферты, носящие добровольный характер и возникающие по инициативе самих регионов для трансляции своих потребностей и интересов, могут стать эффективным механизмом, позволяющим регионам самим осуществлять региональную политику, не прибегая к помощи центра, диктующего условия и устанавливающего ограничения.

Стимулирование межрегиональной кооперации и сотрудничества, в том числе путем введения «горизонтальных» межбюджетных трансфертов, реализуемых в рамках государственной программы ${ }^{18}$, названо одним из приоритетов государственной политики в сфере управления региональными и муниципальными финансами. Аналогичные положения содержатся и в других документах, например, в Концепции повышения эффективности бюджетных расходов в 2019-2024 гг. ${ }^{19}$, Основных направлениях деятельности Правительства Российской Федерации на период до 2024 г., Публичной декларации целей и задач Министерства финансов России.

Самого термина «горизонтальные субсидии» в законодательстве не содержится. Под субсидиями бюджету одного региона из бюджета другого региона понимаются межбюджетные трансферты, предоставляемые в целях

${ }^{17}$ Статья 142.2 Бюджетного кодекса Российской Федерации.

18 Об утверждении государственной программы Российской Федерации «Развитие федеративных отношений и создание условий для эффективного и ответственного управления региональными и муниципальными финансами»: Постановление Правительства Российской Федерации от 18.05.2016 № 445 .

19 Об утверждении Концепции повышения эффективности бюджетных расходов в 2019-2024 годах: Распоряжение Правительства Российской Федерации от 31.01.2019 №117-р. 
софинансирования расходных обязательств при выполнении полномочий региональных органов власти по предметам их ведения и предметам совместного ведения регионов и Федерации и расходных обязательств по выполнению полномочий органов местного самоуправления по решению вопросов местного значения (ст. 138.3 Бюджетного кодекса Российской Федерации). В то же время в разъяснениях Минфина России к закону термин «горизонтальные субсидии» все же упоминается ${ }^{20}$.

Цели и условия предоставления таких субсидий должны устанавливаться соглашениями между высшими исполнительными органами государственной власти соответствующих регионов. Таким образом, на федеральном уровне не устанавливаются цели и условия предоставления таких трансфертов, кроме общей цели софинансирования расходных обязательств. В результате на практике цели предоставления такого трансферта могут оказаться очень широкими.

Соглашения должны заключаться в порядке, установленном законом или нормативными правовыми актами высшего исполнительного органа государственной власти того региона, из бюджета которого предоставляется субсидия. В настоящее время таких актов на уровне регионов принято совсем немного. Это можно объяснить как тем, что не все регионы будут использовать инструмент горизонтальных субсидий, так и тем, что федеральные нормы, регламентирующие предоставление подобных субсидий, вступили в силу в 2020 г.

Регионы стали вносить изменения в свои законы, регламентирующие бюджетное устройство, бюджетный процесс или межбюджетные отношения, включив в них упоминание о возможности предоставления такого вида субсидий (например, Орловская, Пензенская области, Ханты-Мансийский автономный округ). При этом, как правило, условия предоставления субсидий не фиксировались. Порядок заключения таких соглашений установлен в Алтайском крае ${ }^{21}$, Вологодской ${ }^{22}$, Орловской ${ }^{23}$ и Тюменской ${ }^{24}$ областях.

20 Об особенностях предоставления межбюджетных трансфертов: Письмо Министерства финансов России от 19.02.2020 № 06-01-14/11889.

${ }^{21}$ Об утверждении Правил заключения соглашений между Правительством Алтайского края и высшими исполнительными органами государственной власти субъектов Российской Федерации о предоставлении субсидий бюджетам субъектов Российской Федерации из краевого бюджета: Постановление Правительства Алтайского края от 20.12.2019 № 527.

22 Об утверждении Порядка заключения соглашений о предоставлении субсидий из областного бюджета бюджетам субъектов Российской Федерации: Постановление Администрации Волгоградской области от 05.03.2020 № 121-п.

${ }^{23}$ Об утверждении Порядка заключения соглашений между Правительством Орловской области и высшими исполнительными органами государственной власти иных субъектов Российской Федерации о предоставлении из областного бюджета субсидий бюджетам соответствующих субъектов Российской Федерации: Постановление Правительства Орловской области от 04.03.2020 № 120 .

${ }^{24} \mathrm{O}$ внесении изменений в Закон Тюменской области «О межбюджетных отношениях в Тюменской области»: Закон Тюменской области от 05.11.2019 № 64. 
Хотя практика предоставления подобных трансфертов существовала и до принятия поправок в Бюджетный кодекс Российской Федерации, она попрежнему весьма немногочисленна. Ключевым примером является практика российской столицы. Так, гл. 4 Закона города Москвы от 10.09.2008 № 39 «О бюджетном устройстве и бюджетном процессе в городе Москве» не содержит ${ }^{25}$ упоминания о такой форме трансфертов, хотя в апреле 2020 г. положения, касающиеся форм межбюджетных трансфертов в этом законе были существенно пересмотрены ${ }^{26}$. Однако уже в 2018 г. такие субсидии выдавались очень активно: более 20 видов трансфертов было предоставлено из бюджета Москвы бюджетам 13 регионов на различные цели, в частности, на оснащение медицинских учреждений, благоустройство территорий, развитие транспортной инфраструктуры, развитие системы образования и др. ${ }^{27}$.

В 2019 г. трансферты из бюджета Москвы получили 11 регионов $^{28}$. Перечень направлений при этом остался достаточно широким. Если судить по приказу Департамента финансов г. Москвы, число горизонтальных трансфертов в 2020 г. резко сократилось, несмотря на появление соответствующего инструмента на уровне федерального законодательства. В бюджетной классификации отражены только субсидии бюджетам Калужской, Московской, Саратовской и Тверской областей ${ }^{29}$.

Наряду с направлениями финансирования за 2015-2018 гг. выросли и объемы «горизонтальных» трансфертов из бюджета г. Москвы. Так, если в 2016-2017 гг. сумма субсидий составила чуть более 3 млрд руб., то уже в 2018 г. она выросла примерно в восемь раз, при этом доля «горизонтальных» субсидий от общего объема расходов бюджета города была более $1 \%$. Наибольшие объемы средств были направлены на реализацию различных инфраструктурных проектов, на строительство, реконструкцию и капитальный ремонт объектов социальной инфраструктуры.

В таблице 2 представлен более подробный перечень направлений, объемов и регионов - получателей финансирования из бюджета г. Москвы.

${ }^{25}$ По состоянию на 1 октября 2020 г.

${ }^{26}$ О внесении изменений в Закон города Москвы от 10 сентября 2008 года № 39 «О бюджетном устройстве и бюджетном процессе в городе Москве» и приостановлении действия отдельных положений Закона города Москвы от 10 сентября 2008 года № 39 «О бюджетном устройстве и бюджетном процессе в городе Москве»: Закон города Москвы от 07.05.2020 № 7.

${ }^{27} \mathrm{O}$ порядке применения бюджетной классификации расходов и источников финансирования дефицита бюджета города Москвы и утверждении Перечня главных распорядителей бюджетных средств: Приказ Департамента финансов г. Москвы от 29.12.2017 № 383.

${ }^{28} \mathrm{O}$ порядке формирования и применения бюджетной классификации расходов и источников финансирования дефицита бюджета города Москвы и утверждении Перечня главных распорядителей бюджетных средств города Москвы»: Приказ Департамента финансов г. Москвы от 29.12.2018 № 460 .

29 О Порядке формирования и применения бюджетной классификации расходов и источников финансирования дефицита бюджета города Москвы и утверждении Перечня главных распорядителей бюджетных средств города Москвы: Приказ Департамента финансов г. Москвы от 31.12.2019 № 424 . 


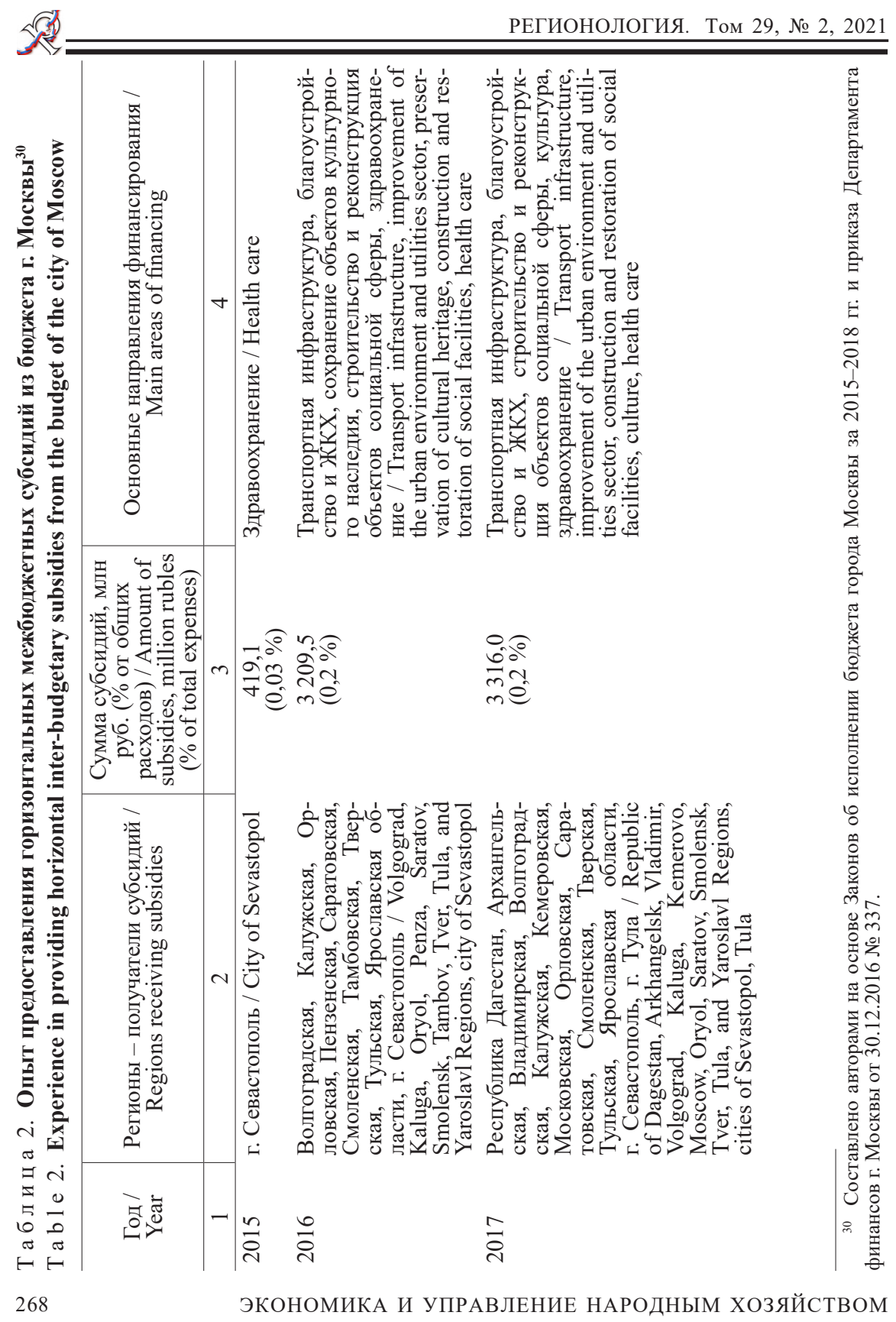




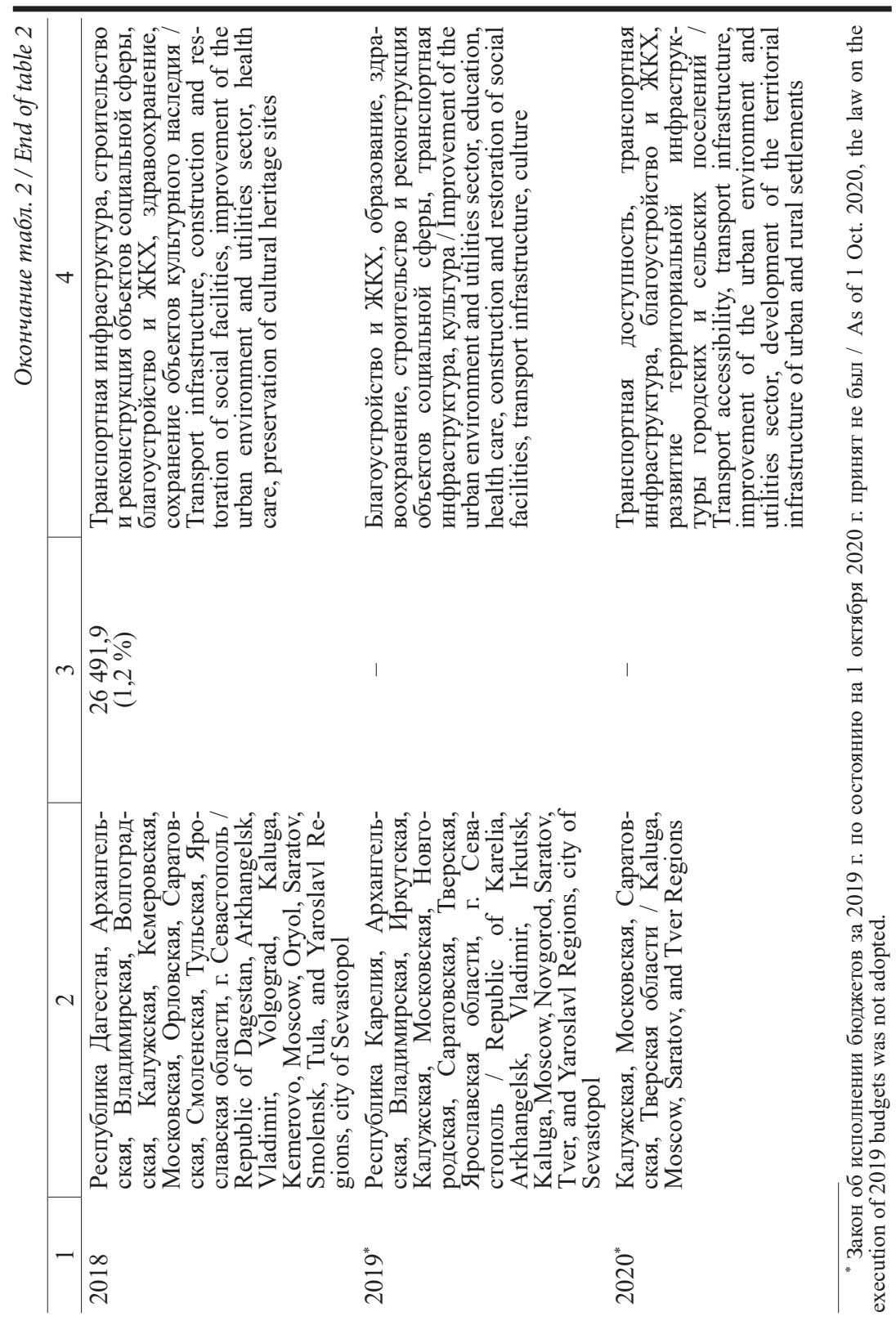


Результаты анализа законов об исполнении бюджета г. Москвы свидетельствуют о том, что основная часть направлений финансирования - это непрограммные направления деятельности органов государственной власти. В рамках программного бюджета реализация «горизонтальных» субсидий происходила лишь дважды: на проведение капитального ремонта и ремонта автомобильных дорог в Московской области (по направлению «Градостроительная политика», подпрограмма «Развитие и реорганизация территорий»), а также на реконструкцию канализационных очистных сооружений в Тверской области (по направлению «Развитие коммунально-инженерной инфраструктуры и энергосбережение», подпрограмма «Развитие и модернизация водопроводно-канализационного хозяйства города Москвы и систем технического водоснабжения»).

В практике г. Москвы выявляется также такой уникальный случай, как предоставление трансферта из бюджета субъекта Федерации бюджету муниципального образования, расположенного в другом регионе. Так, г. Туле была предоставлена субсидия на проведение работ по перекладке и устройству инженерных систем и благоустройству территории.

Аналогичные примеры «горизонтальных» трансфертов имеются и во взаимоотношениях Санкт-Петербурга и Ленинградской области, например, в части передачи субсидии на возмещение затрат организациям, осуществляющим пассажирские перевозки на общественном транспорте СанктПетербурга льготных категорий граждан - жителей области ${ }^{31}$.

В 2019 г. предоставление «горизонтальных» субсидий было предусмотрено и во взаимоотношениях Тюменской и Курганской областей, между которыми заключено соглашение о предоставлении субсидии на решение вопросов местного значения ${ }^{32}$. В рамках соглашения предусмотрено предоставление в 2020-2021 гг. из бюджета Тюменской области субсидии в целях софинансирования строительства (реконструкции), модернизации объектов водоотведения, что позволит предотвратить угрозу распространения инфекционных заболеваний и пагубного воздействия на экосистему ОбьИртышского бассейна.

Другим уникальным примером является соглашение о предоставлении субсидии из бюджета Томской области бюджету Ханты-Мансийского автономного округа на финансирование строительства мостового перехода на автомобильной дороге Нижневартовск - Стрежевой.

Таким образом, в рамках межрегионального взаимодействия в основном речь идет о достижении взаимных интересов регионов, часто - соседствующих. Однако существующая практика демонстрирует, что предоставлять

${ }^{31}$ Постановление Правительства Ленинградской области от 23.12.2008 № 408.

32 Об утверждении Соглашения между Правительством Тюменской области и Правительством Курганской области о предоставлении субсидии из бюджета Тюменской области бюджету Курганской области от 19 ноября 2019 года: Закон Тюменской области от 28.11.2019 № 82 . 
другим регионам субсидии могут пока только сверхобеспеченные субъекты Федерации, к которым относятся Москва, Ханты-Мансийский автономный округ - Югра и Тюменская область как регионы-доноры. Действия г. Москвы могут считаться примером лучшей практики, в том числе с учетом разнообразных форм ее реализации, даже в условиях отсутствия законодательного регулирования института «горизонтальных» трансфертов, которые только начинают находить свое применение в бюджетной деятельности иных регионов.

Другим финансовым механизмом межбюджетного выравнивания являются «горизонтальные» бюджетные кредиты, возможность предоставления которых появилась в бюджетном законодательстве в апреле 2020 г.: регионы получили возможность выдавать друг другу бюджетные кредиты на срок до трех лет. Цели предоставления бюджетного кредита и размеры платы за его пользование устанавливаются законом субъекта-кредитора ${ }^{33}$. При этом на такие кредиты не распространяются некоторые условия и ограничения, предусмотренные в ст. 93.2 Бюджетного кодекса Российской Федерации. Например, цели предоставления кредита и размеры платы за его использование устанавливаются законом региона о бюджете или решением высшего исполнительного органа государственной власти региона, а выдача, использование и возврат таких кредитов осуществляются в порядке, установленном высшим исполнительным органом государственной власти субъекта Федерации - кредитора.

Возможность регионов кредитовать друг друга появилась в ответ на сильный шок, нанесенный экономике и бюджетам регионов коронакризисом 2020 г. Регионы, тяжело проходящие кризис несмотря на финансовую поддержку из центра, получили новые возможности на обеспечение заметно возросших расходных обязательств за счет бюджетов регионов, которые меньше пострадали или оправились от шока быстрее.

Предполагается, что горизонтальные бюджетные кредиты, наряду с более активным использованием горизонтальных межбюджетных трансфертов, позволят оперативно и точечно решать возникающие в регионах проблемы без дополнительных обращений к федеральному центру за новыми бюджетными кредитами.

В таблице 3 представлены отличительные характеристики горизонтальных бюджетных кредитов и горизонтальных субсидий.

Ключевым отличием этих двух механизмов является возвратность предоставляемых средств. Если бюджетные кредиты предоставляются возвратно и возмездно, и выгода региона-кредитора в основном материального характера-за счет возврата средств с процентами, то в случае с «горизонтальными» межбюджетными трансфертами ситуация иная: характер предоставления субсидии безвозвратный и безвозмездный, а бенефициаром выступает регион, получающий субсидию.

${ }^{33} \mathrm{O}$ внесении изменений в Бюджетный кодекс Российской Федерации и Федеральный закон «О приостановлении действия отдельных положений Бюджетного кодекса Российской Федерации и установлении особенностей исполнения бюджетов бюджетной системы Российской Федерации в 2020 году»: Федеральный закон от 22.04.2020 № 120-Ф3. 


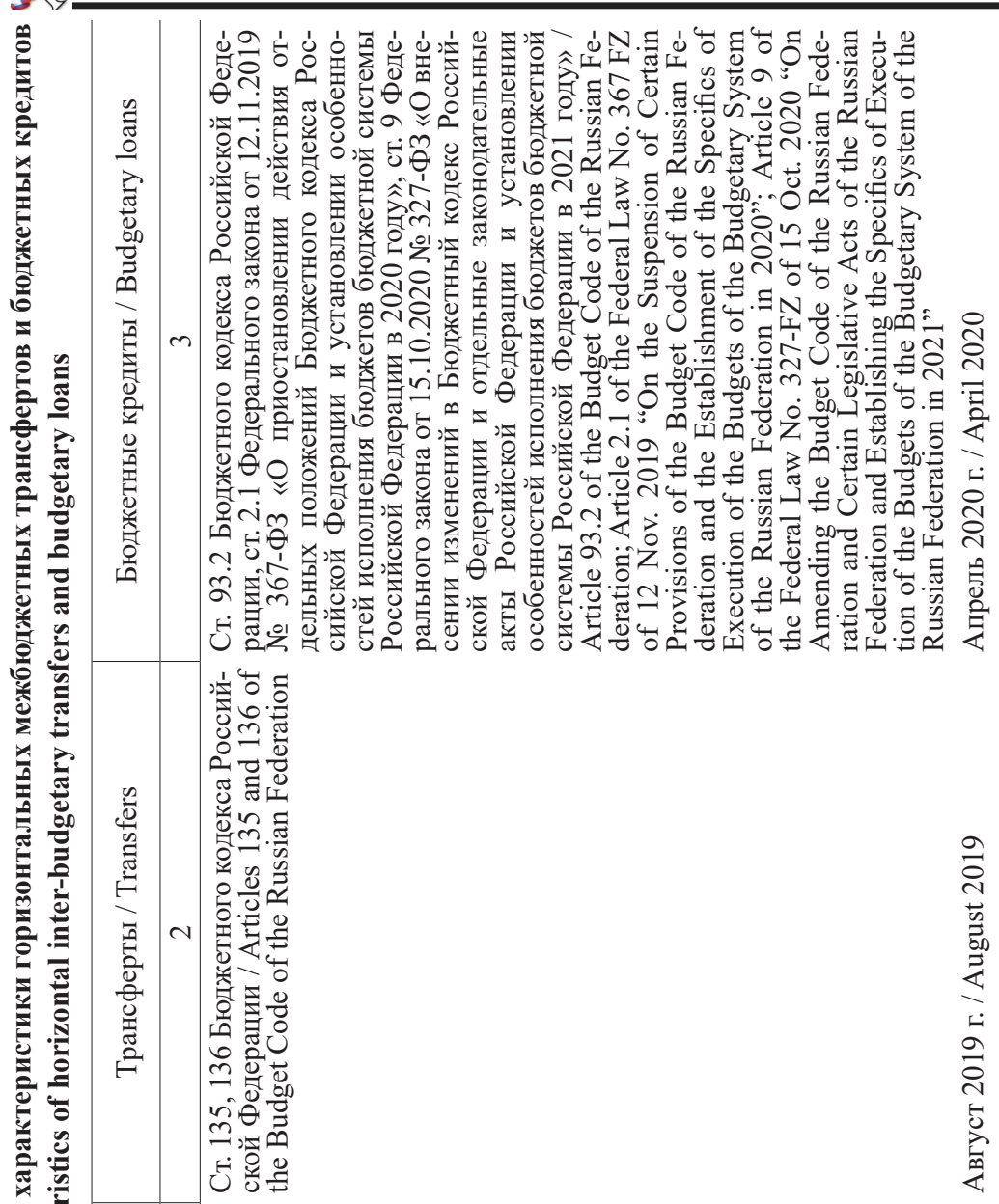

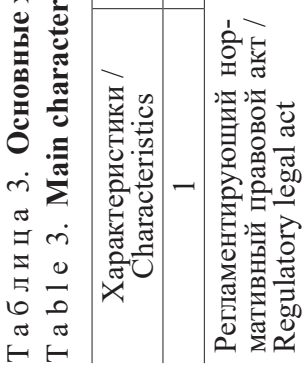

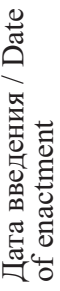




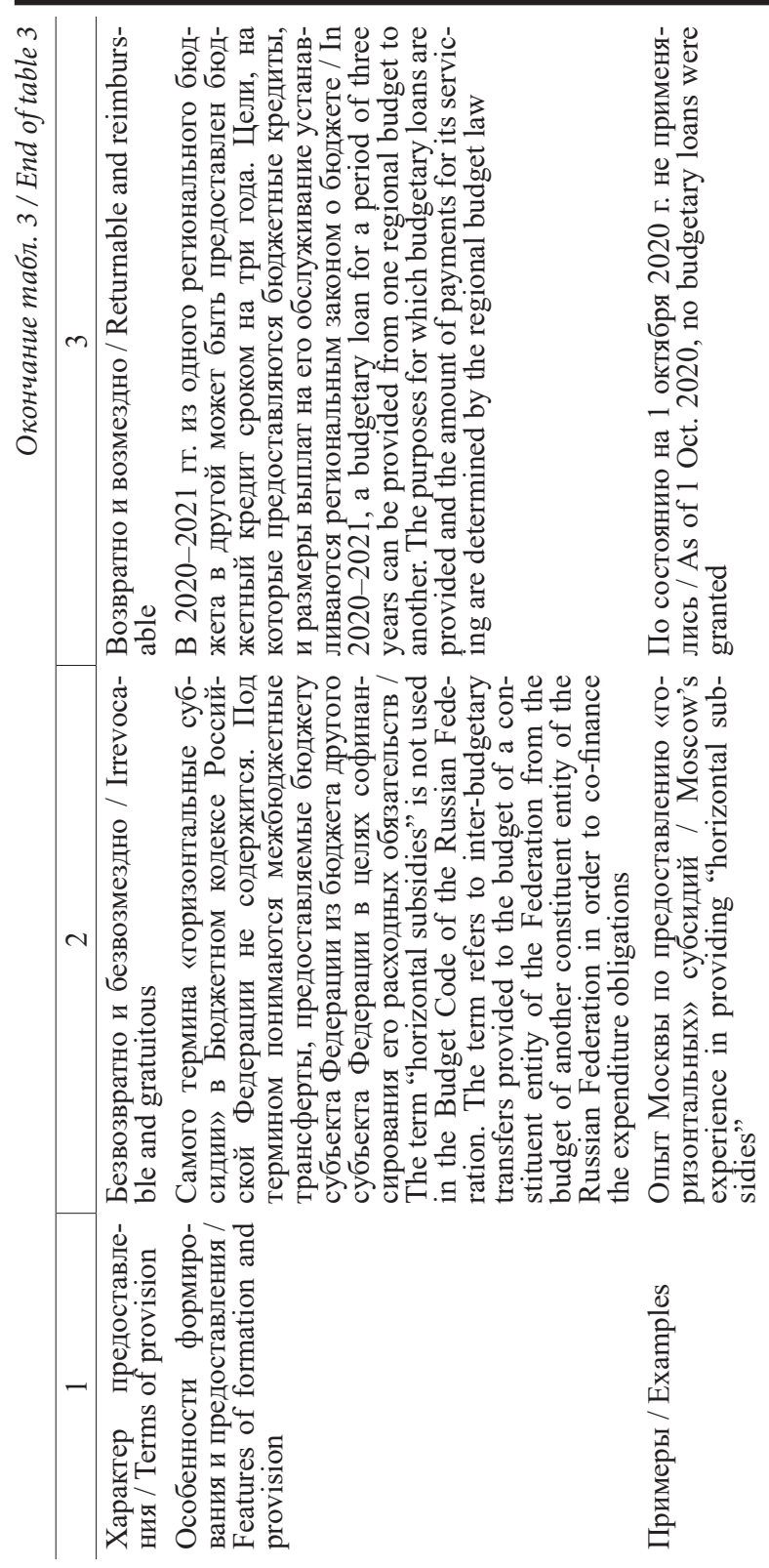


Для предоставления «горизонтальной» субсидии, очевидно, регион должен обладать высокой бюджетной обеспеченностью. В этой связи «горизонтальные» субсидии могут создавать выгоды для обоих участвующих в этом процессе регионов (например, через описанные выше строительство связывающего два региона моста, решение общих экологических проблем), однако скорее выступают как инструмент лоббирования регионом, выделяющим субсидию, своих интересов, решения политических задач, часто не находящих формального правового закрепления и имеющих понятные для всех мотивы.

Об эффективности взаимного бюджетного кредитования регионов пока судить сложно, однако уже сейчас эксперты высказываются о том, что ввиду незначительных объемов остатков бюджетных средств на счетах, а также очень маленькой процентной ставки по кредиту $(0,1 \%)$ число регионов-кредиторов в перспективе будет весьма ограничено. По оценкам, кредиторами могут стать не более 25 регионов ${ }^{34}$. Некоторые эксперты отмечают, что разрешение кредитования регионов друг другом - попытка центра сэкономить собственные средства на поддержку регионов ${ }^{35}$.

В то же время следует отметить достаточно высокую степень свободы, предоставляемой регионам в использовании обоих инструментов: цели, условия и особенности их применения определяются регионами самостоятельно и закрепляются в соответствующих региональных актах. Это в свою очередь расширяет возможности межрегионального взаимодействия.

Право на взаимное кредитование регионов пролонгировано и на 2021 г. Аналогично в рамках изменений бюджетного законодательства, принятых во втором полугодии 2020 г., предусмотрена возможность предоставления «горизонтальных» бюджетных кредитов между муниципалитетами одного субъекта Федерации ${ }^{36}$.

Обсуждение и заключение. Несмотря на то, что в последние десятилетия в Российской Федерации шли процессы складывания новых и обновления уже действующих экономических институтов, межрегиональное сотрудничество в полной мере не заработало. Более того, в законодательстве практически отсутствуют механизмы и инструменты его поддержки. Межрегиональное сотрудничество, хотя и начинает появляться в ключевых документах стратегического планирования, до сих пор не определено как самостоятельное направление государственной политики.

${ }^{34}$ Регионам России разрешат кредитовать друг друга [Электронный ресурс] // PБК. URL: https://www.rbc.ru/economics/16/04/2020/5e9827c09a7947c991aa1f19 (дата обращения: 01.09.2020).

35 Правительство снимет запрет на кредитование одного региона другим [Электронный ресурс] // Ведомости. URL: https://www.vedomosti.ru/economics/news/2020/04/16/828209-pravitelstvosnimet-zapret-na-kreditovanie-odnogo-regiona-drugim (дата обращения: 01.09.2020).

${ }^{36} \mathrm{O}$ внесении изменений в Бюджетный кодекс Российской Федерации и отдельные законодательные акты Российской Федерации и установлении особенностей исполнения бюджетов бюджетной системы Российской Федерации в 2021 году: Федеральный закон от 15.10.2020 № 327-Ф3. 
В 2019 г. в законодательство были внесены изменения, касающиеся возможности применения механизма «горизонтальных» трансфертов, а в 2020 г. - механизма взаимного кредитования регионов. Однако методические основы данных инструментов остаются не проработанными, а эффективность их не подвергается оценке. Предусмотренные механизмы работают практически в индивидуальных случаях.

В целом инструменты межрегионального сотрудничества можно классифицировать по их статусу: одни закреплены в нормативных правовых актах, и взаимодействие регионов в таком случае формализовано, другие носят фрагментарный характер либо вообще уже не используются. Существуют также формы, которые применяются регионами добровольно на основе взаимовыгодного сотрудничества (в рамках соглашений), а есть те, в которые регионы вынуждены вовлекаться в соответствии с федеральной повесткой.

Можно выделить перспективные и неперспективные формы межрегионального сотрудничества. К первым, например, относятся горизонтальные межбюджетные трансферты, ко вторым - ассоциации экономического взаимодействия.

Таким образом, в условиях новых вызовов, в том числе связанных с закрытием государственных границ, разрывом существующих хозяйственных и социальных связей, актуальным является поиск совместных возможностей регионов и муниципалитетов по консолидации усилий и ресурсов для преодоления кризисных явлений. Необходимость выработки принципов, подходов и требований к осуществлению взаимодействия регионов с разными уровнями социально-экономического развития и выявления возможностей и ограничений осуществления такого взаимодействия нарастает.

В этой связи в качестве предложений для федерального правительства по решению вопроса активизации и систематизации межрегионального сотрудничества целесообразным было бы принятие и осуществление комплекса мер и мероприятий, касающихся нормативно-правового регулирования, административно-управленческих решений и действий, связанных с их реализацией в практической работе органов государственной власти.

Прежде всего следует провести доформирование законодательных основ, позволяющих регионам осуществлять различные формы межрегионального взаимодействия, не нарушая нормы бюджетного, гражданского и иного законодательства.

Как частный случай требуется провести установление обязательного требования по включению в содержание стратегий социально-экономического развития субъектов Федерации положений, касающихся взаимодействия с другими регионами. Аналогичные нормы в обязательном порядке могли бы закрепляться и в других документах стратегического планирования. Это потребует внесения изменений в ст. 32 и другие положения Федерального 
закона от 28.06.2014 № 172-Ф3 «О стратегическом планировании в Российской Федерации».

Важным является приоритетное включение в государственные программы развития макрорегионов проектов и мероприятий, касающихся двух и более субъектов Федерации и имеющих сугубо межрегиональный характер. При этом, в случае включения мероприятий, осуществляемых в одном регионе, было бы целесообразно приводить обоснование их межрегиональной значимости. Нужно провести создание институтов развития взаимодействия регионов, в том числе координационных органов, занимающихся межрегиональным сотрудничеством на федеральном уровне и согласованием интересов регионов и Федерации. В свете изменения роли Государственного Совета Российской Федерации, определенного изменениями в Конституции Российской Федерации, принятыми в 2020 г., такие функции было бы целесообразно возложить именно на этот орган власти. В то же время и другим органам власти и существующим институтам развития могут быть приданы дополнительные функции в части стимулирования межрегионального взаимодействия.

Важным в рамках развития межрегионального взаимодействия является дальнейшая проработка таких новых финансовых механизмов, как «горизонтальные» субсидии и бюджетные кредиты.

Отдельного внимания заслуживает вопрос установления полномочий органов исполнительной власти субъектов Федерации по содействию развитию межмуниципального сотрудничества. С точки зрения методического обеспечения процесса межрегионального взаимодействия представляется важным запустить полноценный мониторинг существующих форм взаимодействия и сотрудничества регионов с целью выявления регионов - центров такой активности и потенциальных его направлений, а также с целью распространения создать банк данных с лучшими практиками межрегионального и межмуниципального сотрудничества.

Статья будет полезна федеральным органам исполнительной власти (Аппарату Правительства Российской Федерации, Министерству экономического развития России, Министерству финансов России и др.) в части совершенствования существующих и разработки новых форм межрегионального сотрудничества регионов, а также для органов власти субъектов Федерации в контексте оценки их возможностей для кооперации с другими регионами, анализа и использования лучшей практики. Кроме того, включение в содержание стратегий социально-экономического развития регионов положений, касающихся взаимодействия с другими регионами, сделает значимый вклад в развитие системы стратегического планирования, обеспечив комплексный подход к оценке социально-экономического положения, возможностей и ограничений развития регионов. 


\section{СПИСОК ИСПОЛЬЗОВАННЫХ ИСТОЧНИКОВ}

1. Лексин, В. Н. Оценка результативности государственных программ социальноэкономического развития регионов России / В. Н. Лексин, Б. Н. Порфирьев // Проблемы прогнозирования. - 2016. - № 4 (157). - C. 81-94. - URL: https://ecfor.ru/wpcontent/uploads/2017/01/08-rezultativnost-gosudarstvennyh-programm-razvitiya-regionov. pdf (дата обращения: 01.09.2020).

2. Klimanov, V. Economic and Fiscal Resilience of Russia's Regions / V. Klimanov, S. Kazakova, A. Mikhaylova. - DOI 10.1111/rsp3.12282 // Regional Science, Policy and Practice. - 2020. - Vol. 12, issue 4. - Pp. 627-640. - URL: https://rsaiconnect.onlinelibrary. wiley.com/doi/abs/10.1111/rsp3.12282 (дата обращения: 01.09.2020).

3. Haggay, E. When Trade Stops: Lessons from the Gaza Blockade 2007-2010 / E. Haggay, Z. Assaf. - DOI 10.1016/j.jinteco.2014.10.005 // Journal of International Economics. 2015. - Vol. 95, no. 1. - Pp. 16-27. - URL: https://www.sciencedirect.com/science/article/ pii/S0022199614001172 (дата обращения: 01.09.2020).

4. Захаренко, Р. Л. Пол Кругман: нобелевский лауреат, теоретик международной торговли и экономической географии / Р. Л. Захаренко // Экономический журнал Высшей школы экономики. - 2009. - № 1. - C. 130-137. - URL: https://ej.hse.ru/data/2010/1 2/31/1208181948/13 01 08.pdf (дата обращения: 01.09.2020).

5. Глазьев, С. Ю. Н̈а верном пути интеграции / С. Ю. Глазьев // Евразийская интеграция: экономика, право, политика. - 2010. - № 8. - C. 32-35. - URL: https:// cyberleninka.ru/article/n/na-vernom-puti-integratsii (дата обращения: 01.09.2020).

6. Yaskal, I. The Theoretical Aspects of Integration Processes on the Regional Level / I. Yaskal, A. Nedelea // The Annals of the "Stefan cel Mare" University of Suceava. Fascicle of the Faculty of Economics and Public Administration. - 2010. - Vol. 10, no. 1 (11). Pp. 27-34. - URL: https://www.researchgate.net/publication/224048074_The theoretical aspects_of_integration_processes_on_the_regional_level (дата обращения: 01.09.2020).

7. Peña, S. Mobility Planning in Cross-Border Metropolitan Regions: The European and North American Experiences / S. Peña, F. Durand. - DOI 10.1080/21622671.2020.1769716// Territory, Politics, Governance. - 2020. - Pp. 1-18. - URL: https://www.tandfonline.com/ doi/full/10.1080/21622671.2020.1769716 (дата обращения: 01.09.2020).

8. Plangger, M. Exploring the Role of Territorial Actors in Cross-Border Regions / M. Plangger. - DOI 10.1080/21622671.2017.1336938 // Territory, Politics, Governance. 2017. - Pp. 1-21. - URL: https://www.tandfonline.com/doi/full/10.1080/21622671.2017.1 336938 (дата обращения: 01.09.2020).

9. Pinson, G. Beyond Neoliberal Imposition: State-Local Cooperation and the Blending of Social and Economic Objectives in French Urban Development Corporations / G. Pinson, C. M. Journel. - DOI 10.1080/21622671.2016.1153512 // Territory, Politics, Governance. 2016. - Vol. 4, issue 2. - Pp. 173-195. - URL: https://www.tandfonline.com/doi/full/10.10 80/21622671.2016.1153512 (дата обращения: 01.09.2020).

10. Area Development and Policy: An Agenda for the $21^{\text {st }}$ Century / M. Dunford, Yu. Aoyama, C. C. Diniz [et al.]. - DOI 10.1080/23792949.2016.1158621// Area Development and Policy. - 2016. - Vol. 1, issue 1. - Pp. 1-14. - URL: https://www.tandfonline.com/doi/abs/10.1080/23792949.2016.1158621?journalCode=rard20 (дата обращения: 01.09.2020). 
11. Urban-Rural Integration Drives Regional Economic Growth in Chongqing, Western China / W. Liu, M. Dunford, Zh. Song, M. Chen. - DOI 10.1080/23792949.2016.1151758 // Area Development and Policy. - 2016. - Vol. 1, issue 1. - Pp. 132-154. - URL: https://www. tandfonline.com/doi/abs/10.1080/23792949.2016.1151758 (дата обращения: 01.09.2020).

12. Puntigliano, A. R. $21^{\text {st }}$ Century Geopolitics: Integration and Development in the Age of 'Continental States' / A. R. Puntigliano. - DOI 10.1080/21622671.2016.1220867 // Territory, Politics, Governance. - 2016. - Vol. 5, issue 4. - Pp. 478-494. - URL: https://www. tandfonline.com/doi/full/10.1080/21622671.2016.1220867 (дата обращения: 01.09.2020).

13. Mueller, S. Centralization Through Decentralization? The Crystallization of Social Order in the European Union / S. Mueller, M. Hechter. - DOI 10.1080/21622671.2 019.1676300 // Territory, Politics, Governance. - 2019. - Pp. 1-20. - URL: https://www. tandfonline.com/doi/full/10.1080/21622671.2019.1676300 (дата обращения: 01.09.2020).

14. Кофанов, А. А. Зарубежный опыт межрегиональной экономической интеграции как фактора социально-экономического развития региона / А. А. Кофанов // Pегиональная экономика: теория и практика. - 2010. - № 31. - C. 60-64. - URL: https:// www.fin-izdat.ru/journal/region/detail.php?ID=29875 (дата обращения: 01.09.2020).

15. Абдулманапов, С. Г. Интеграционные процессы в регионах Северокавказского федерального округа / С. Г. Абдулманапов // ЭТАП: экономическая теория, анализ, практика. - 2014. - № 3. - С. 40-52. - URL: http://etap.instet.ru/images/etap/ Etap_03_2014.pdf (дата обращения: 01.09.2020).

16. Бородин, В. А. Экономическая интеграция регионов Юго-Западной Сибири: проектный подход / В. А. Бородин, В. А. Голощапова, А. В. Ерохин // Экономика, профессия, бизнес. - 2017. - № 2. - С. 5-14. - URL: http://journal.asu.ru/ec/article/view/1953 (дата обращения: 01.09.2020).

17. Кузнецова, О. В. Межрегиональное сотрудничество в России: перспективы кооперации региональных властей / О. В. Кузнецова // Региональные исследования. 2019. - № 1. - C. 16-25. - URL: http://www.geogr.msu.ru/structure/reg_issledovaniya/ RI_2019_1(63).pdf (дата обращения: 01.09.2020).

18. Interregion Cooperation in Russia on the Example of North-West Federal District / O. Bakumenko, S. Demidova, O. Derevianko [et al.] // International Journal of Civil Engineering and Technology. - 2019. - Vol. 10, issue 2. - Pp. 2057-2066. - URL: https://www. researchgate.net/publication/332251241_Interregional_cooperation_in_Russia_on_the_example of the north-west federal district (дата обращения: 01.09.2020).

19. Дубровская, Ю. В. Особенности межрегионального взаимодействия в экономической сфере: эволюционно-правовой аспект / Ю. В. Дубровская // Государственная власть и местное самоуправление. - 2017. - № 8. - С. 47-51. - URL: http://www. lawinfo.ru/catalog/contents-2017/gosudarstvennaja-vlast-i-mestnoe-samoupravlenie/8/ (дата обращения: 01.09.2020).

20. Кузнецова, О. В. Стратегия пространственного развития Российской Федерации: иллюзия решений и реальность проблем / О. В. Кузнецова // Пространственная экономика. - 2019. - T. 15, № 4. - C. 107-125. - URL: http://spatial-economics.com/en/ archive/2019-4/868-SE-2019-4-107-125 (дата обращения: 01.09.2020).

21. Лавров, А. М. Децентрализация бюджетных доходов: международные сравнения и российские перспективы / А. М. Лавров, Е. А. Домбровский // Финансы. - 2016. - № 5. - C. 16-27. - URL: http://www.finance-journal.ru/index. php?part=finance\&num=201605 (дата обращения: 01.09.2020). 
22. Михайлова, А. А. Влияние межбюджетных трансфертов на экономический рост и структуру региональной экономики / А. А. Михайлова, В. В. Климанов, А. И. Сафина. DOI 10.32609/0042-8736-2018-1-91-103 // Вопросы экономики. - 2018. - № 1. - С. 91-103. URL: https:/www.vopreco.ru/jour/article/view/371 (дата обращения: 01.09.2020).

23. Силуанов, А. Г. Анализ возможностей совершенствования механизма «отрицательного трансферта» в России / А. Г. Силуанов // Экономическая политика. - 2011. № 3. - C. 70-80. - URL: http://ecpolicy.ru/archiv/2011/3\#title (дата обращения: 01.09.2020).

24. Pike, A. What Kind of Local and Regional Development and for Whom? / A. Pike, A. Rodríguez-Pose, J. Tomaney. - DOI 10.1080/00343400701543355 // Regional Studies. - 2007. - Vol. 41, issue 9. - Pp. 1253-1269. - URL: https:/www.tandfonline.com/doi/ full/10.1080/00343400701543355 (дата обращения: 01.09.2020).

Поступила 17.12.2020; одобрена после рецензирования 14.01.2021; принята к публикации 25.01.2021.

\section{Об авторах:}

Климанов Владимир Викторович, директор Центра региональной политики Института прикладных экономических исследований ФГБОУ ВО «Российская академия народного хозяйства и государственной службы при Президенте Российской Федерации» (119571, Российская Федерация, г. Москва, пр-т Вернадского, д. 82, стр. 1), директор АНО «Институт реформирования общественных финансов» (125009, Российская Федерация, г. Москва, Большой Кисловский переулок, д. 1, стр. 2), доктор экономических наук, ORCID: https://orcid.org/0000-0001-9282-0812, Scopus ID: 57196979592, Researcher ID: O-6341-2018,vvk@irof.ru

Казакова Софья Михайловна, младший научный сотрудник Центра региональной политики Института прикладных экономических исследований ФГБОУ ВО «Российская академия народного хозяйства и государственной службы при Президенте Российской Федерации» (119571, Российская Федерация, г. Москва, пр-т Вернадского, д. 82, стр. 1), эксперт АНО «Институт реформирования общественных финансов» (125009, Российская Федерация, г. Москва, Большой Кисловский переулок, д. 1, стр. 2), ORCID: https://orcid.org/0000-0002-2306-7924, Scopus ID: 57205303601, Researcher ID: Q-3093-2019, smk@irof.ru

Яговкина Вита Александровна, ведущий научный сотрудник Центра региональной политики Института прикладных экономических исследований ФГБОУ ВО «Российская академия народного хозяйства и государственной службы при Президенте Российской Федерации» (119571, Российская Федерация, г. Москва, пр-т Вернадского, д. 82, стр. 1), ведущий консультант-юрист АНО «Институт реформирования общественных финансов» (125009, Российская Федерация, г. Москва, Большой Кисловский переулок, д. 1, стр. 2), кандидат юридических наук, доцент, ORCID: https://orcid. org/0000-0001-5448-9508, vaya@irof.ru

\section{Заявленный вклад авторов:}

В. В. Климанов - постановка проблемы исследования; научное руководство; формулирование основной концепции исследования; формулирование результатов исследования и выводов; критический анализ и доработка текста. 
С. М. Казакова - подготовка текста статьи; подготовка графических результатов исследования; формулирование выводов; разработка рекомендаций.

В. А. Яговкина - подготовка текста статьи; разработка рекомендаций.

Авторы прочитали и одобрили окончательный вариант рукописи.

\section{REFERENCES}

1. Leksin V.N., Porfiryev B.N. Evaluation of the Effectiveness of Government Programs of Socioeconomic Development of Regions of Russia. Problemy Prognozirovaniya = Studies on Russian Economic Development. 2016; 27:418-428. (In Eng.) DOI: https://doi. org/10.1134/S1075700716040109

2. Klimanov V., Kazakova S., Mikhaylova A. Economic and Fiscal Resilience of Russia's Regions. Regional Science, Policy and Practice. 2020; 12(4):627-640. (In Eng.) DOI: https://doi.org/10.1111/rsp3.12282

3. Haggay E., Assaf Z. When Trade Stops: Lessons from the Gaza Blockade 2007-2010. Journal of International Economics. 2015; 95(1):16-27. (In Eng.) DOI: https://doi. org/10.1016/j.jinteco.2014.10.005

4. Zakharenko R.L. Paul Krugman: the Nobel Prize Winner, the Theorist of International Trade and Economic Geography. Ehkonomicheskij zhurnal Vysshej shkoly ehkonomiki = Higher School of Economics Economic Journal. 2009; (1):130-137. Available at: https://ej.hse.ru/data/2 010/12/31/1208181948/13_01_08.pdf (accessed 01.09.2020). (In Russ., abstract in Eng.)

5. Glaziev S.Yu. On the Right Track of Integration. Evraziyskaya integratsiya: ehkonomika, pravo, politika = Eurasian Integration: Economics, Law, Politics. 2010; (8):32-35. Available at: https://cyberleninka.ru/article/n/na-vernom-puti-integratsii (accessed 01.09.2020). (In Russ.)

6. Yaskal I., Nedelea A. The Theoretical Aspects of Integration Processes on the Regional Level. In: The Annals of the "Stefan cel Mare" University of Suceava. Fascicle of the Faculty of Economics and Public Administration. 2010; 10(1):27-34. Available at: https:// www.researchgate.net/publication/224048074_The theoretical_aspects_of_integration processes_on the_regional_level (accessed 01.09.2020). (In Eng.)

7. Peña S., Durand F. Mobility Planning in Cross-Border Metropolitan Regions: The European and North American Experiences. Territory, Politics, Governance. 2020. Pp. 1-18. (In Eng.) DOI: https://doi.org/10.1080/21622671.2020.1769716

8. Plangger M. Exploring the Role of Territorial Actors in Cross-Border Regions. Territory, Politics, Governance. 2017. Pp. 1-21. (In Eng.) DOI: https://doi.org/10.1080/21622 671.2017.1336938

9. Pinson G., Journel C.M. Beyond Neoliberal Imposition: State-Local Cooperation and the Blending of Social and Economic Objectives in French Urban Development Corporations. Territory, Politics, Governance. 2016; 4(2):173-195. (In Eng.) DOI: https://doi.org/1 $0.1080 / 21622671.2016 .1153512$

10. Dunford M., Aoyama Yu., Diniz C.C., Kundu A., Limonov L., Lin G., Liu W., Park S. O., Turok I. Area Development and Policy: An Agenda for the $21^{\text {st }}$ Century. Area Development and Policy. 2016; 1(1):1-14. (In Eng.) DOI: https://doi.org/10.1080/2379294 9.2016 .1158621 
11. Liu W., Dunford M., Song Zh., Chen M. Urban-Rural Integration Drives Regional Economic Growth in Chongqing, Western China. Area Development and Policy. 2016; 1(1):132-154. (In Eng.) DOI: https://doi.org/10.1080/23792949.2016.1151758

12. Puntigliano A.R. $21^{\text {st }}$ Century Geopolitics: Integration and Development in the Age of 'Continental States'. Territory, Politics, Governance. 2016; 5(4):478-494. (In Eng.) DOI: https://doi.org/10.1080/21622671.2016.1220867

13. Mueller S., Hechter M. Centralization through Decentralization? The Crystallization of Social Order in the European Union. Territory, Politics, Governance. 2019. Pp. 1-20. (In Eng.) DOI: https://doi.org/10.1080/21622671.2019.1676300

14. Kofanov A.A. Foreign Experience of Inter-Regional Economic Integration as Factor of Social and Economic Development of Region. Regionalnaya ehkonomika: teoriya i prak$t i k a=$ Regional Economics: Theory and Practice. 2010; (31):60-64. Available at: https:// www.fin-izdat.ru/journal/region/detail.php?ID=29875 (accessed 01.09.2020). (In Russ., abstract in Eng.)

15. Abdulmanapov S.G. Integration Processes in Regions of North Caucasus Federal District. ETAP: ehkonomicheskaya teoriya, analiz, praktika = ETAP: Economic Theory, Analysis, and Practice. 2014; (3):40-52. Available at: http:/etap.instet.ru/images/etap/ Etap_03_2014.pdf (accessed 01.09.2020). (In Russ., abstract in Eng.)

16. Borodin V.A., Goloshchapova I.A., Erokhin A.V. Regional Economic Integration in South-Western Siberia: A Project-Based Approach. Ehkonomika, Professiya, Biznes = Economics, Profession, Business. 2017; (2):5-14. Available at: http://journal.asu.ru/ec/article/ view/1953 (accessed 01.09.2020). (In Russ., abstract in Eng.)

17. Kuznetsova O.V. Interregional Cooperation in Russia: Prospects of Regional Governments' Cooperation. Regionalnye issledovaniya = Regional Studies. 2019; (1):16-25. Available at: http://www.geogr.msu.ru/structure/reg_issledovaniya/RI_2019_1(63).pdf (accessed 01.09.2020). (In Russ., abstract in Eng.)

18. Bakumenko O., Demidova S., Derevianko O., Akhmatova I., Mitrofanov A., Asadpoor A. Interregion Cooperation in Russia on the Example of North-West Federal District. International Journal of Civil Engineering and Technology. 2019. 10(2):2057-2066. Available at: https://www.researchgate.net/publication/332251241_Interregional_cooperation in_Russia_on_the_example_of_the_north-west_federal_district (accessed ${ }^{-}$01.09.2020). (In Eng.)

19. Dubrovskaya Yu.V. Peculiarities of Trans-Regional Interaction in Economic Sector: Evolutionary and Legal Aspect. Gosudarstvennaya vlast $i$ mestnoe samoupravlenie $=$ State Power and Local Self-Government. 2017; (8):47-51. Available at: http://www.lawinfo. $\mathrm{ru} / \mathrm{catalog} /$ contents-2017/gosudarstvennaja-vlast-i-mestnoe-samoupravlenie/8/ (accessed 01.09.2020). (In Russ., abstract in Eng.)

20. Kuznetsova O.V. Problems of Elaboration of Spatial Development Strategy of the Russian Federation. Prostranstvennaya ehkonomika = Spatial Economics. 2019; 15(4):107-125. Available at: http://spatial-economics.com/en/archive/2019-4/868SE-2019-4-107-125 (accessed 01.09.2020). (In Russ., abstract in Eng.)

21. Lavrov A.M., Dombrovskiy E.A. Decentralization of Budget Incomes: International Comparisons and Russian Prospects. Finansy = Finance. 2016; (5):16-27. Available at: http:// www.finance-journal.ru/index.php?part=finance\&num=201605 (accessed 01.09.2020). (In Russ., abstract in Eng.) 
22. Mikhaylova A.A., Klimanov V.V., Safina A.I. The Impact of Intergovernmental Fiscal Transfers on Economic Growth and the Structure of the Regional Economy. Voprosy ehkonomiki = Issues of Economics. 2018; (1):91-103. (In Russ., abstract in Eng.) DOI: https://doi.org/10.32609/0042-8736-2018-1-91-103

23. Siluanov A.G. Analysis of Opportunities for Improving the Mechanism of "Negative Transfer" In Russia. Ehkonomicheskaya politika = Economic Policy. 2011; (3):70-80. Available at: http://ecpolicy.ru/archiv/2011/3\#title (accessed 01.09.2020). (In Russ., abstract in Eng.)

24. Pike A., Rodríguez-Pose A., Tomaney J. What Kind of Local and Regional Development and for Whom? Regional Studies. 2007; 41(9):1253-1269. (In Eng.) DOI: https://doi.org/10.1080/00343400701543355

Submitted 17.12.2020; approved after reviewing 14.01.2021; accepted for publication 25.01.2021.

About the authors:

Vladimir V. Klimanov, Director, Center for Regional Policy, Institute for Applied Economic Research, Russian Presidential Academy of National Economy and Public Administration (Bldg 1, 82 Vernadskogo Ave., Moscow 119571, Russian Federation); Director, Institute for Public Finance Reform (Bldg 2, 1 Bolshoy Kislovsky Lane, Moscow 125009, Russian Federation), Dr. Sci. (Economics), ORCID: https://orcid.org/0000-00019282-0812, Scopus ID: 57196979592, Researcher ID: O-6341-2018,vvk@irof.ru

Sofia M. Kazakova, Junior Researcher, Center for Regional Policy, Institute for Applied Economic Research, Russian Presidential Academy of National Economy and Public Administration (Bldg 1, 82 Vernadskogo Ave., Moscow 119571, Russian Federation); Expert, Institute for Public Finance Reform (Bldg 2, 1 Bolshoy Kislovsky Lane, Moscow 125009, Russian Federation), ORCID: https://orcid.org/0000-0002-2306-7924, Scopus ID: 57205303601, Researcher ID: Q-3093-2019,smk@irof.ru

Vita A. Yagovkina, Leading Researcher, Center for Regional Policy, Institute for Applied Economic Research, Russian Presidential Academy of National Economy and Public Administration (Bldg 1, 82 Vernadskogo Ave., Moscow 119571, Russian Federation); Leading Legal Consultant, Institute for Public Finance Reform (Bldg 2, 1 Bolshoy Kislovsky Lane, Moscow 125009, Russian Federation), Cand. Sci. (Law), Associate Professor, ORCID: https://orcid.org/0000-0001-5448-9508, vaya@irof.ru

\section{Contribution of the authors:}

V. V. Klimanov - statement of the research problem; academic supervision; formulation of the basic concept of the study; evaluation of the results; drawing conclusions; critical analysis and revision of the text of the article.

S. M. Kazakova - preparation of the text of the article; graphical representation of the research results; drawing conclusions; putting forward recommendations.

V. A. Yagovkina - preparation of the text of the article; putting forward recommendations.

The authors have read and approved the final version of the manuscript. 
УДК 332.14

DOI: $10.15507 / 2413-1407.115 .029 .202102 .283-305$

Оригинальная статья / Original article http://regionsar.ru

ISSN 2587-8549 (Print)

ISSN 2413-1407 (Online)

\section{Роль стратегий в диверсификации экономики регионов: запланированное развитие против незапланированных результатов}

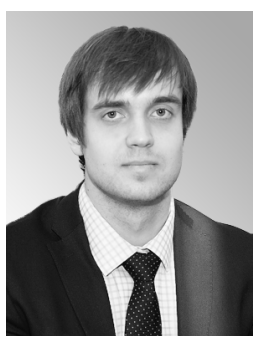

Я. Ю. Еферин

ФГАОУ ВО «Наииональный исследовательский университет «Высшая школа экономики»

(2. Москва, Российская Федерачия), yeferin@worldbank.org

Введение. Вопросы долгосрочного стратегического планирования имеют определяющее значение для успешного социальноэкономического развития регионов России. Вместе с тем обоснованность выбора отраслевых приоритетов часто не подкрепляется комплексным анализом уникальных конкурентных преимуществ региона, что затрудняет достижение поставленных задач. Цель статьи - по результатам проведенного исследования выявить связи между заявленными приоритетами и структурными изменениями в российских регионах, в частности появлением в регионах новых отраслей специализации.

Материалы и методы. В основе исследования - стратегии социально-экономического развития российских регионов, принятые с 2005 по 2010 г. Методом контентанализа документов сформирован перечень приоритетных отраслей, заявленных в стратегиях 66 субъектов Российской Федерации. Для определения диверсификации региональных отраслевых портфелей использована адаптированная методология Европейской кластерной обсерватории по выявлению отраслевых специализаций.

Результаты исследования. Проведенный анализ стратегических документов показал, что отраслевые приоритеты российских регионов не отражают их уникальных специализаций, а сфокусированы на наиболее общих для экономики России сектоpax. В каждой второй стратегии пищевая промышленность и тяжелое машиностроение были заявлены в качестве приоритетов долгосрочного развития. Диверсификация региональных отраслевых портфелей зафиксирована в 46 регионах. Всего выявлено 76 случаев возникновения отраслей в региональных портфелях с 2005 по 2015 г. В 11 регионах заявленные отраслевые приоритеты оказались оторванными от реальных процессов диверсификации.

Обсуждение и заключение. Настоящее исследование показывает, что диверсификация экономики во многих российских регионах незапланированная. Это не столько результат стратегического решения региональных органов власти, сколько воздействие неучтенных при выборе отраслевых приоритетов факторов, оказывающих существенное влияние на отраслевое развитие. Разработанные в статье положения и региональные классификации могут быть полезны для развития теории государственного и муниципального управления в части оценки влияния управленческих решений на социально-экономическое развитие территорий.

Еферин Я. Ю., 2021

Контент доступен под лицензией Creative Commons Attribution 4.0 License. This work is licensed under a Creative Commons Attribution 4.0 License. 
Ключевые слова: отраслевое развитие регионов, стратегическое планирование, отраслевой приоритет, структурная трансформация, диверсификация экономики, структурная политика, региональная экономическая политика

Автор заявляет об отсутствии конфликта интересов.

Благодарности: Автор выражает благодарность кандидату экономических наук Е. С. Куценко за консультационную и экспертную поддержку, а также экспертам Российской кластерной обсерватории за помощь со сбором данных. Отдельную благодарность автор выражает рецензенту, чьи ценные комментарии позволили улучшить качество текста.

Для цүитирования: Еферин, Я. Ю. Роль стратегий в диверсификации экономики регионов: запланированное развитие против незапланированных результатов / Я. Ю. Еферин. - DOI 10.15507/2413-1407.115.029.202102.283-305 // Регионология. - 2021. T. 29, № 2. - C. 283-305.

\title{
The Role of Strategies in Diversification of Regional Economies: Planned Development versus Unplanned Results
}

\author{
Ya. Yu. Eferin \\ National Research University Higher School of Economics \\ (Moscow, Russian Federation), \\ yeferin@worldbank.org
}

Introduction. The issues of long-term strategic planning are crucial for the successful socioeconomic development of Russia's regions. At the same time, the validity of the choice of industry priorities is often not supported by a comprehensive analysis of the unique competitive advantages of the region, which makes it difficult to achieve the established goals. The purpose of the study is to identify the links between the stated priorities and structural changes in Russia's regions, particularly, the emergence of new industries of specialization in the regions.

Materials and Methods. The study was based on the strategies for socio-economic development of Russia's regions adopted in 2005-2010. The method of content analysis of documents was employed when forming a list of the priority industries declared in the strategies of 66 constituent entities of the Russian Federation. The adapted methodology of the European Cluster Observatory for identifying industry specializations was used to determine the diversification of regional industry portfolios.

Results. The conducted analysis of the strategic documents has shown that the industry priorities of Russia's regions do not reveal their unique specializations, but are focused on the sectors which are most common for the Russian economy. In half of the strategies the food industry and heavy engineering are named as priorities for long-term development. Diversification of regional industry portfolios has been recorded in 46 regions. A total of 76 cases of industries emerging in regional portfolios from 2005 to 2015 have been identified. In 11 regions, the declared industry priorities have not been associated to the real processes of diversification.

Discussion and Conclusion. The study has revealed that the diversification of the economy in many Russia's regions is unplanned. This is not so much the result of a strategic decision of regional authorities, but rather the impact of factors that are not taken into account when choosing industry priorities, which have a significant impact on industry development. The provisions and regional classifications developed in the article may contribute to the 
development of the theory of public and municipal administration in terms of assessing the impact of managerial decisions on the socio-economic development of territories.

Keywords: sectoral development of regions, strategic planning, sectoral priority, structural transformation, diversification of economy, structural policy, regional economic policy

The author declares that there is no conflict of interest.

Acknowledgements. The author expresses gratitude to E. S. Kutsenko, Cand. Sci. (Economics), for consulting and expert support, as well as to the experts of the Russian Cluster Observatory for their help with data collection. The author expresses special gratitude to the reviewer, whose valuable comments made it possible to improve the quality of the text.

For citation: Eferin Ya.Yu. The Role of Strategies in Diversification of Regional Economies: Planned Development versus Unplanned Results. Regionology = Russian Journal of Regional Studies. 2021; 29(2):283-305. DOI: https://doi.org/10.15507/24131407.115.029.202102.283-305

Введение. Долгосрочное стратегическое планирование считается важным политическим инструментом для выявления возможностей роста и путей диверсификации экономики, для своевременного реагирования на экономические и финансовые кризисы и в целом для обеспечения устойчивого социально-экономического развития [1]. Руководство регионов разрабатывает стратегии долгосрочного развития, намечает пути и направления, определяет отраслевые приоритеты для диверсификации экономики. Однако выбор тех или иных приоритетов часто происходит без учета комплексного анализа конкурентных преимуществ региона, что заметно тормозит процессы диверсификации региональной экономики. Цель статьи - по материалам проведенного исследования выявить наличие связи между отраслевыми приоритетами и структурными изменениями в регионах. Для этого автор отвечает на вопрос, связаны ли новые отрасли специализации с приоритетными отраслями, заявленными в региональных стратегиях социально-экономического развития, или структурные изменения происходят без привязки к стратегическому решению региональных властей.

Обзор литературы. Назначение и методы стратегического планирования изучаются экономистами и политиками еще с прошлого века как в контексте управления частными организациями, так и в рамках государственного управления ${ }^{1}$, в том числе на региональном уровне [2]. У. Окасио, Дж. Джозеф определяют стратегическое планирование как механизм выбора целей и направлений для их достижения [3]; П. Котлер, К. Келлер - как набор методов создания и поддержания соответствия между целями, навыками и ресурсами

${ }^{1}$ Kotler Ph., Armstrong G., Wong V., Saunders J. Principles of Marketing: Third European Edition. Harlow: Prentice Hall, 2001. 888 p.; Ferrell O. C., Hartline M. D. Marketing Management Strategies. Mason: South-Western Cengage Learning, 2011. 743 p. 
с учетом меняющихся тенденций [4]; П. Дойл - как процесс выявления конкурентных преимуществ и реагирования на экономические, политические, социальные и природные изменения [5].

П. Файфилд утверждает, что стратегическое планирование должно строиться на доказательной базе и критической массе выявленных сравнительных преимуществ [6]. Выбор приоритетных направлений и формирование соответствующей региональной политики предполагает понимание отраслевых специализаций региона [7], поиск закономерностей в изменениях структуры экономики ${ }^{2}$, поддержку конкурентных секторов и развитие новых, связанных с ними индустрий [8;9].

Эксперты уделяют особое внимание вопросам выявления отраслевых специализаций $[10 ; 11]$ и нахождения связей между прошлой, настоящей и будущей структурой экономики региона [12]. Исследования показывают, что развитие новых индустрий, связанных с отраслевой структурой региона, ведет к экономическому росту и повышает уровень занятости в регионе, так как новые связанные отрасли приводят к появлению новых продуктов и услуг, не требующих радикально новых производственных мощностей или квалификаций [13; 14]. Напротив, несвязанное развитие обладает более неопределенными выгодами для экономики региона, для которого потребуется радикально новая инфраструктура, навыки и капитал $[15 ; 16]$. Поэтому понимание текущих отраслевых специализаций является основой для выбора путей связанного развития экономики региона и для формирования долгосрочных отраслевых приоритетов.

В научной литературе обосновано наличие положительной связи между стратегическим планированием и развитием экономики региона [17; 18]. Например, А. Ханссон изучил стратегию городского планирования в Швеции в 2010-2014 гг., которая отразилась на сокращении расходов на жилье, совершенствовании закона о городском планировании и формировании политики муниципального зонирования для решения задач социального жилья [19]. Исследование А. де Монтис посвящено изучению эффектов региональной политики в секторе энергетики в регионах Италии. Автор показывает, как в стратегических документах фокус на анализе экологической составляющей регионов отразился на сокращении затрат на электроэнергию [20]. На примере транспортного сектора М. Мондрагон-Иштлауак, Ж. Кортес-Мартинес, Д. Дельгадо-Эрнандес отмечают положительное влияние стратегического планирования на оптимизацию движения железнодорожных поездов между регионами Мексики [21]. Исследования подтверждают значимость анализа имеющихся секторов для выбора приоритетных направлений.

Россия имеет длительный опыт разработок долгосрочных планов развития экономики на национальном, региональном, муниципальном уровнях. В советский период на развитие системы стратегического планирования влияние

${ }^{2}$ Salet W. G. M., Faludi A. The Revival of Strategic Spatial Planning. Amsterdam: Royal Netherlands Academy of Arts and Sciences, 2000. 300 p. 
оказала теория и практика народно-хозяйственного планирования ${ }^{3}$ В ее основе - сочетание отраслевого и территориального планирования, а также развитие системы балансового планирования народного хозяйства [22].

Для современной России вопросы долгосрочного стратегического планирования имеют актуальное значение, учитывая существенную дифференциацию регионов по уровню социально-экономического развития и неравенства ${ }^{4}$. Текущие экономические условия вынуждают регионы придерживаться стратегии бюджетной консолидации, снижения затрат, направленных на обеспечение и повышение качества жизни, а также поиска новых путей для диверсификации региональной экономики ${ }^{5}$.

В регионах система стратегического планирования состоит из таких ключевых элементов, как стратегия социально-экономического развития и государственные программы российских регионов. Согласно требованиям федерального закона о стратегическом планировании ${ }^{6}$, они являются основными документами, в которых заложены приоритеты развития региона [23].

Отечественные ученые (например, Е. И. Добролюбова, Е. И. Клочкова [24], В. Н. Южаков [25], А. В. Клименко, В. А. Королев, Д. Ю. Двинских, И. Ю. Сластихина ${ }^{7}$ ) подчеркивают, что целеполагание, прогнозирование и выбор приоритетов (как в масштабах всей страны, так и на уровне регионов) лежат в основе эффективности стратегического планирования. Но, как, в частности, считают М. П. Буров ${ }^{8}$, В. В. Климанов, Н. А. Чернышова, Д. А. Недопивцева [23], повышению эффективности препятствует низкое качество проработки конкурентных преимуществ. В большинстве стратегий социально-экономического развития российских регионов для оценки отраслевых специализаций и выбора приоритетов используется SWOT-анализ. Однако анализ проводится с целью оценки общей социально-экономической ситуации в регионе без выделения конкретных отраслей [26; 27]. Такой под-

Канторович Л. В. Экономический расчет наилучшего использования ресурсов. М.: Изд-во АН СССР, 1959. 344 с.; Новожилов В. В. Проблемы измерения затрат и результатов при оптимальном планировании. М.: Наука, 1972. 434 с.; Звездин 3. К. От плана ГОЭЛРО к плану первой пятилетки: становление социалистического планирования в СССР. М.: Наука, 1979. 269 с.

4 Лексин В. Н., Швецов А. Н. Государство и регионы. Теория и практика государственного регулирования территориального развития. М.: Либроком, 2016. 368 с.

5 Буров М. П. Государственное регулирование национальной экономики: современные парадигмы и механизмы развития российских регионов. М.: Дашков и Ко, 2018. 342 с.; Стратегическое планирование в Российской Федерации: состояние методического обеспечения / А. В. Клименко, В. А. Королев, Д. Ю. Двинских [и др.] // Аналитический доклад (по результатам мониторинга реализации Федерального закона от 28 июня 2014 г. № 172-Ф3 «О стратегическом планировании в Российской Федерации»). Препринт WP8/2016/02 2016. М.: Изд. дом Высш. шк. экономики, 2016. 60 с.

${ }^{6}$ О стратегическом планировании в Российской Федерации: Федеральный закон от 28.06.2014 № 172-Ф3.

${ }^{7}$ Клименко А. В., Королев В. А., Двинских Д. Ю., Сластихина И. Ю. О гармонизации документов государственного стратегического планирования. М.: НИУ ВШЭ, 2015. 48 с.

${ }^{8}$ Буров М. П. Государственное регулирование национальной экономики: современные парадигмы и механизмы развития российских регионов. 
ход приводит к дублированию содержания региональных документов социально-экономического развития, неоптимальному распределению ресурсов, затрудняет процессы диверсификации региональной экономики и в итоге ведет к невозможности достижения заявленных приоритетов.

Недостаточную проработанность документов стратегического планирования можно объяснить также тем, что в федеральном законе о стратегическом планировании и его подзаконных актах нет четких требований и единых стандартов для выделения специализаций и формирования приоритетных отраслей для долгосрочного социально-экономического развития региона. Вопросами планирования занимаются территории, но без единообразного, комплексного и актуализируемого подхода им трудно прогнозировать социально-экономическое планирование на длительную перспективу. В Стратегии пространственного развития России ${ }^{9}$ далее - Стратегия) ставится задача снижения межрегиональной дифференциации социально-экономического развития регионов, в том числе за счет поддержки отраслевых специализаций. При этом ни в Стратегии, ни в Плане реализации Стратегии не предусмотрен единый подход к формированию отраслевых приоритетов. В частности, представленный в Стратегии перечень перспективных специализаций получил научно-обоснованную критику со стороны ряда ученых [28].

Материалы и методы. В статье используется сформированная база отраслевых приоритетов из стратегий социально-экономического развития субъектов Российской Федерации, принятых с 2005 по 2010 г. Для анализа региональных специализаций применяется адаптированный метод Европейской кластерной обсерватории $[10 ; 11]$ и система взаимосвязи отраслей по методу Портера [29].

Статья включает обзор отраслевых приоритетов из стратегий долгосрочного развития регионов и анализ их связи со структурными изменениями в регионах. На основе полученных данных сделаны выводы о роли долгосрочных приоритетов в отраслевом развитии российских регионов. Таблицы и рисунки в данной работе составлены автором.

В целях исследования была сформирована база отраслевых приоритетов, заявленных в стратегиях социально-экономического развития субъектов Российской Федерации. Для анализа отраслевых приоритетов включены стратегии 66 регионов, принятые с 2005 по 2010 г. $^{10}$. В случае если за

${ }^{9}$ Стратегия пространственного развития Российской Федерации на период до 2025 года утверждена Распоряжением Правительства Российской Федерации от 13.02.2019 № 207-р.

10 В анализе также учитывались стратегии регионов, которые были приняты в период 2011-2013 гг., ввиду отсутствия таковых в рамках изучаемого периода, включая стратегии г. Москвы, Костромской, Орловской, Тверской, Мурманской, Саратовской, Новгородской, Амурской, Сахалинской, Еврейской автономной областей, Республики Дагестан, Чеченской Республики, Пермского, Красноярского краев. Стратегии Рязанской, Тульской, Ярославской, Архангельской областей, Кабардино-Балкарской Республики, Республики Татарстан, Томской области, Республики Саха (Якутия), Чукотского автономного округа не учитывались в анализе по причине отсутствия утвержденных документов стратегического социально-экономического развития вплоть до 2014-2015 гг. 
этот период было принято две и более стратегии, в анализе учитывалась наиболее актуальная.

Методом контент-анализа документов сформирован перечень приоритетных отраслей, заявленных в стратегиях социально-экономического развития в разрезе каждого региона изучаемой совокупности. Для проверки обоснованности заявленных приоритетов региональные документы анализировались через следующие параметры: описание возможностей и угроз, описание ресурсной базы для развития отрасли, разработанность целевых показателей, направлений и мероприятий по их достижению. Чтобы определить процессы диверсификации, были выявлены отрасли, появившиеся в составе региональных отраслевых портфелей с 2005 по 2015 г. Для оценки состава отраслевых портфелей использована адаптированная методология Европейской кластерной обсерватории по установлению отраслевых специализаций ${ }^{11}$. В рамках методологии взят во внимание перечень из 51 отрасли (автомобилестроение, пластмассовые изделия, фармацевтическая продукция, строительство и др.), каждая из которых объединяет связанные виды экономической деятельности ${ }^{12}$.

Методология применена на выборке из 71 региона России с 2005 по 2015 г. $^{13}$. Для количественных расчетов использовались данные ОКВЭД-1 четвертого уровня детализации по показателю «Средняя численность работников за отчетный период, чел.» ${ }^{14}$. Результатом стали перечни новых отраслей специализации для 46 регионов. При этом отрасль считалась новой только в том случае, если она была в составе отраслевого портфеля в течение трех лет (с 2013 по 2015 г.) и не являлась таковой в течение 2005-2007 гг.

Так, за прошедшее десятилетие новые отрасли появлялись чаще всего в регионах Центрального федерального округа и Приволжья (Владимирской, Брянской, Тульской, Смоленской областях, Удмуртии и др.). За рассматри-

11 Согласно методологии, отраслевые специализации региона определяются через расчет двух показателей - коэффициента локализации и абсолютного размера отрасли в регионе. Коэффициент локализации рассчитывается через отношение доли отрасли в экономике региона к доле отрасли в экономике страны. Размер отрасли рассчитывается через отношение отраслевой занятости региона к отраслевой занятости по стране. Отрасль считается специализацией региона, если одновременно выполняется два условия: вхождение региона в 80 \% регионов по показателю размера отрасли и в 20 \% регионов по показателю коэффициента локализации. Фильтрующее условие позволяет сфокусироваться на наиболее значимых отраслях для региона.

${ }_{12}$ Например, такая отрасль, как строительство, включает производство цемента, стекловолокна, гипса, общестроительных работ по возведению мостов, прокладке автомобильных дорог и другие связанные виды экономической деятельности.

${ }^{13}$ Ввиду отсутствия сопоставимой статистики за рассматриваемый период из выборки были исключены: Адыгея, Карачаево-Черкесия, Калмыкия, Ингушетия, Алтай, Тыва, Хакасия, Еврейская автономная область, Чукотский автономный округ. Ямало-Ненецкий, Ненецкий и ХантыМансийский автономные округа учитывались в составе Тюменской и Архангельской областей.

${ }^{14}$ Расчет производился на основе данных Общероссийского классификатора видов экономической деятельности ОК 029-2007 (КДЕС Ред. 1.1) четвертого уровня детализации по показателям «Средняя численность работников за отчетный период, чел.» согласно форме статистического наблюдения П-4. 
ваемый период Владимирская область стала лидером по количеству новых отраслей: у нее появилось 6 новых специализаций.

В целях исследования был проведен анализ связи между новыми отраслями специализации и текущим отраслевым портфелем. Для определения связи использовался подход М. Портера. В 2016 г. вместе с соавторами он разработал алгоритм определения связи между видами экономической деятельности [28]. В рамках этого подхода определены связи между 51 отраслью. Связанность оценивалась комплексно на основе пространственных корреляций, таблиц «затрат - выпуск», данных по трудоустройству выпускников и анализа конкретных бизнес-примеров. Так, отрасль «автомобилестроение» имеет связь с первичными металлическими и пластмассовыми изделиями, но не имеет связи со строительными материалами. Указанный подход служит основой для более глубокого понимания процессов региональной диверсификации - он позволяет определить, в какой мере новые отрасли являются связанными с экономической структурой региона.

Расчеты показали, что в большинстве случаев новые отрасли в регионах России оказались связанными с отраслевым портфелем: в 55 \% случаев имелась связь со структурой региона, в 45 \% случаев отрасль оказалась несвязанной.

Для целей настоящего исследования выявленные региональные отраслевые приоритеты были приведены в соответствие с указанным перечнем отраслей специализации Европейской кластерной обсерватории. Это позволило оценить наличие связи между отраслевыми приоритетами, заявленными в региональных стратегиях 2005-2010 гг., и новыми отраслями специализации, появившимися за период 2005-2015 гг.

Результаты исследования. В число наиболее распространенных приоритетов субъектов Российской Федерации вошли пищевая промышленность, строительство, тяжелое машиностроение, нефтегазовая отрасль, телекоммуникации, туризм и др. (рис. 1).

Примечательно, что пищевая промышленность и тяжелое машиностроение были заявлены в качестве приоритетов долгосрочного развития в большинстве проанализированных стратегических документов. Остальные отрасли предлагается разделить на группы по степени их распространенности в качестве приоритетных (табл. 1).

В региональных стратегиях в качестве приоритетных чаще всего закладывались отрасли, которые относятся к традиционной промышленности и традиционным услугам. Высокотехнологичная промышленность в меньшей степени указывалась в качестве долгосрочного стратегического актива. Наименее приоритетными отраслями оказались интеллектуальные услуги и креативные индустрии. В частности, финансовые услуги, страхование, издательское дело, дизайн и маркетинг отмечены только в четырех регионах Санкт-Петербурге, Ульяновской области, Республике Мордовия, Хабаровском крае; киноиндустрия и звукозапись вовсе не были заявлены в качестве приоритетных отраслей в региональных стратегиях. 


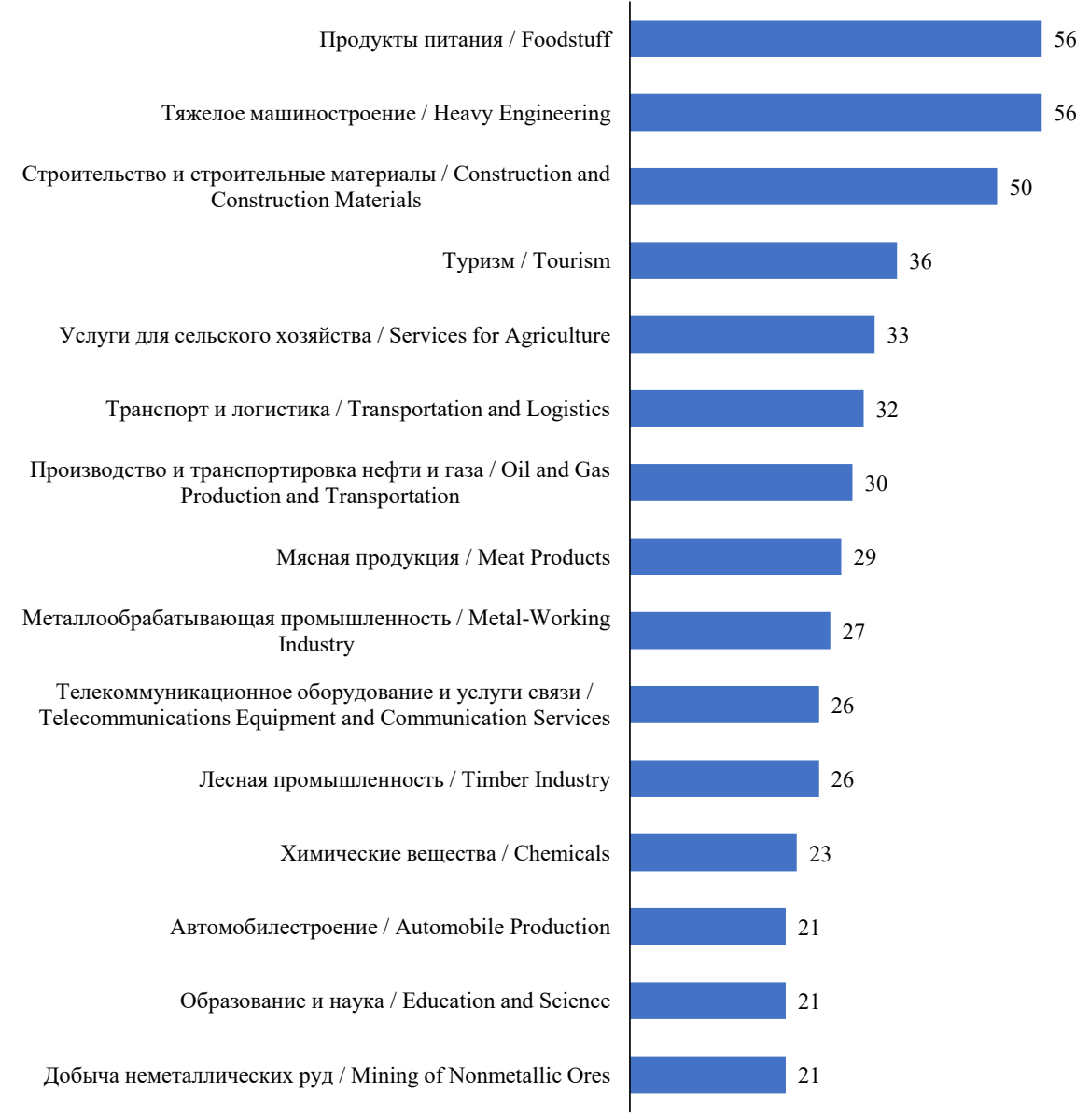

Р и с. 1. Наиболее распространенные отраслевые приоритеты в стратегиях социально-экономического развития регионов России, \% региональных стратегий

$\mathrm{F}$ i g. 1. The most common industry priorities in the strategies for socio-economic development of Russia's regions, \% of regional strategies 
Т а б л и ц а 1. Распространенность отраслей в стратегиях регионов

$\mathrm{T} a \mathrm{~b} l \mathrm{e} 1$. Prevalence of industries in the strategies of the regions

\begin{tabular}{|c|c|c|}
\hline $\begin{array}{c}\text { Наиболее часто } \\
\text { встречаемые отраслевые } \\
\text { приоритеты (в более чем } \\
20 \% \text { стратегий) / Most } \\
\text { common industry priorities } \\
\text { (declared in more than } 20 \% \\
\text { of the strategies) }\end{array}$ & $\begin{array}{c}\text { Приоритеты, которые } \\
\text { встречаются менее чем } \\
\text { в } 20 \% \text { стратегий, но более } \\
\text { чем в 10\% / Priorities } \\
\text { declared in less than } 20 \% \\
\text { but in more than } 10 \% \text { of the } \\
\text { strategies }\end{array}$ & $\begin{array}{c}\text { Наименее } \\
\text { распространенные } \\
\text { приоритеты (менее чем } \\
\text { в 10\% стратегий) / Least } \\
\text { common priorities (declared } \\
\text { in less than } 10 \% \text { of the } \\
\text { strategies) }\end{array}$ \\
\hline Продукты питания / & Химические продукты / & Первичные металлические \\
\hline Foodstuff & Chemical Products & изделия / Upstream Metal \\
\hline Тяжелое & Микроэлектроника & Products \\
\hline машиностроение / Heavy & и приборостроение / & Судостроение и водный \\
\hline Engineering & Microelectronics and & транспорт / Shipbuilding \\
\hline Строительство & Instrument Engineering & and Water Transport \\
\hline и строительные & Добыча металлических & Вторичные металлические \\
\hline материалы / Construction & руд / Mining of Metallic Ores & изделия / Downstream \\
\hline and Construction Materials & Фармацевтическая & Metal Products \\
\hline Туризм / Tourism & продукция / Pharmaceutical & Мебель / Furniture \\
\hline Услуги для сельского & Products & Культура / Culture \\
\hline хозяйства / Services for & Добыча угля / Coal Mining & Огнеупорные материалы \\
\hline Agriculture & Оптовая торговля & и резиновые изделия / \\
\hline Производство & и электронная коммерция / & Fire-Resistant Materials and \\
\hline и транспортировка & e and Electronic & Rubber Products \\
\hline нефти и газа / Oil and & Commerce & Деловые услуги, ИКТ / \\
\hline Gas Production and & Текст & Business Services, ICT \\
\hline Transportation & производство / Textile & Финансовые услуги / \\
\hline Транспорт и логистика /. & Manufacturing & Financial Services \\
\hline Transportation and Logistics & Производство летательных & Пластмассовые изделия / \\
\hline Мясная продукция / Meat & и космических аппаратов / & Plastic Products \\
\hline Products & and Spacecraft & Обувь / Footwear \\
\hline Металлообрабатывающая & Production & Кожаные изделия / Leather \\
\hline $\begin{array}{l}\text { промышленность / Metal- } \\
\text { Working Industry }\end{array}$ & $\begin{array}{l}\text { Рыболс } \\
\text { и прои }\end{array}$ & Goods \\
\hline $\begin{array}{l}\text { Телекоммуникационное } \\
\text { оборудование и услуги }\end{array}$ & $\begin{array}{l}\text { рыбопродуктов / Fishery } \\
\text { and Fish Products }\end{array}$ & $\begin{array}{l}\text { Медоборудование / } \\
\text { Medical Equipment }\end{array}$ \\
\hline $\begin{array}{l}\text { ооорудование и услуги } \\
\text { связи / Telecommunications }\end{array}$ & Изделия из дерева / Wood & Полиграфия и печать / \\
\hline Equipment and & Products & Prin \\
\hline Communication Services & Электрооборудование & Табачные изделия / \\
\hline $\begin{array}{l}\text { Лесная промышленность / } \\
\text { Timber Industry }\end{array}$ & $\begin{array}{l}\text { и осветительные } \\
\text { приборы / Electrical and }\end{array}$ & Одежда / Clothes \\
\hline Химические вещества / & Lighting Equipment & ование / Insurance \\
\hline Chemicals & Целлюлозно-бумаж & Ювелирные изделия / \\
\hline Автомобилестроение / & изделия / Pulp and Paper & Jewelry \\
\hline Automobile Production & oducts & Издательское дело, дизайн \\
\hline Добыча неметаллических & Очистка и распределение & и маркетинг / Publishing, \\
\hline руд / Mining of Metallic Ores & воды, обработка отходов / & Design, and Marketing \\
\hline Образование и наука / & Water Treatment and & \\
\hline Education a & Treatment & \\
\hline
\end{tabular}


Отраслевые приоритеты регионов разнились в зависимости от их географии (рис. 2).

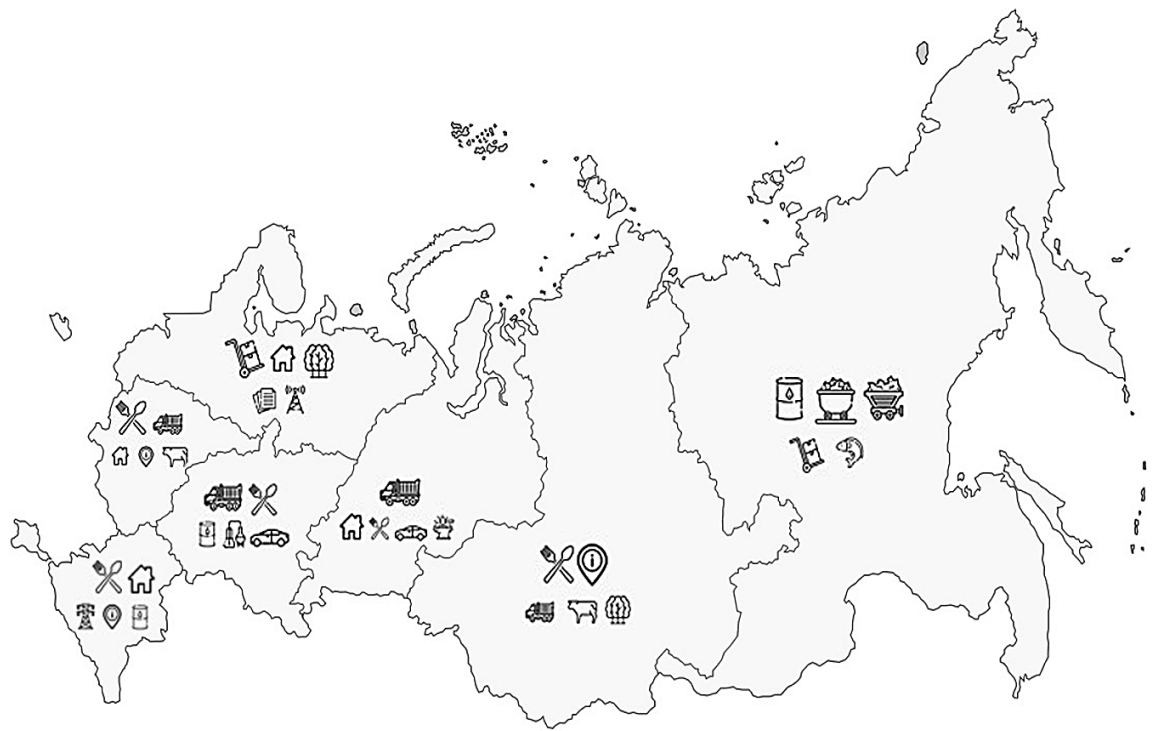

П Продукты питания / Foodstuff

Тяжелое машиностроение / Heavy Engineering

Строительство и строительные

โป материалы / Construction and Construction Materials

(i) Туризм / Tourism

Транспорт и логистика / Transportation and Logistics

G- Мясная продукция / Meat Products

Лесная промышленность / Timber Industry

Целлюлозно-бумажные изделия /

Pulp and Paper Products

((口)") Телекоммуникационное оборудование /

A Telecommunications Equipment
Производство и передача электроэнергии /

Electric Power Generation and Transmission

$\rightarrow$ Производство и транспортировка нефти

и газа/Oil and Gas Production and Transportation

\$ٔी Химические вешества / Chemicals

ه于 Автомобилестроение / Automobile

○े> Металлообрабатывающая

है промышленность / Metal-Working Industry

$\stackrel{20}{\rightleftarrows}$ Добыча угля / Coal Mining

Добыча металлических руд /

Mining of Metallic Ores

9) Рыболовство и производство

рыбопродуктов /Fishery and Fish Products

Р и с. 2. Пять наиболее распространенных отраслевых приоритетов российских регионов по федеральным округам (Южный и Северо-Кавказский федеральные округа объединены для наглядности)

F i g. 2. Five most common industry priorities of Russia's regions by Federal District (the Southern and North Caucasian Federal Districts combined for illustrative purposes) 
В центральной части страны зафиксировано производство продуктов питания, строительных материалов, развитие туризма. В первую тройку приоритетов северных регионов вошли транспорт и логистика, лесная промышленность, телекоммуникации. У южных регионов прослеживается уклон в сторону сельского хозяйства, производства электроэнергии и строительных материалов. В регионах Приволжья и Урала лидировали тяжелое машиностроение, пищевое производство и строительство. В сибирских регионах в список приоритетов часто попадали туризм, сельское хозяйство, лесная промышленность. Дальний Восток отличается от других регионов - здесь первоочередными приоритетами являлись нефть и газ, добыча металлических руд и угля.

Наибольшее количество приоритетов было заявлено в Ростовской, Тверской, Владимирской, Ульяновской областях, Республике Башкортостан, наименьшее - в стратегиях Тувы, Адыгеи, Алтая, Кемеровской области и др.

По количеству заявленных отраслевых приоритетов регионы условно можно распределить по следующим группам:

- регионы с наибольшим количеством приоритетов (было заявлено в среднем более 10 отраслевых приоритетов; 13 субъектов $\left.{ }^{15}\right)$;

- регионы с умеренным количеством приоритетов (было заявлено по 7 отраслей; 37 субъектов $^{16}$ );

- регионы с наименьшим количеством заявивших приоритетных отраслей (по 5 отраслевых приоритетов; 16 субъектов $^{17}$ ).

$\mathrm{У}$ регионов с наибольшим количеством приоритетов зафиксирован более высокий уровень регионального богатства (табл. 2). Третью часть этих регионов составили крупные экономические центры. Вероятно, богатые и экономически развитые регионы могут выбирать более диверсифицированный путь развития своей экономики в отличие от менее обеспеченных регионов.

${ }^{15}$ К группе относятся: Владимирская, Ростовская, Тверская, Ульяновская, Омская, Вологодская, Калининградская, Новгородская, Саратовская, Свердловская области, Республика Башкортостан, г. Санкт-Петербург, Краснодарский край.

${ }^{16}$ К группе относятся: Республика Коми, Калужская, Ленинградская, Кировская, Челябинская области, Республика Дагестан, Республика Бурятия, Новосибирская, Белгородская, Брянская, Воронежская, Курская, Московская, Мурманская, Псковская, Волгоградская области, Республика Марий Эл, г. Москва, Пермский, Алтайский, Забайкальский, Приморский, Хабаровский края, Амурская, Ивановская, Костромская области, Республика Северная Осетия - Алания, Чеченская Республика, Ставропольский край, Республика Мордовия, Нижегородская, Оренбургская, Пензенская, Курганская, Иркутская области, Красноярский, Камчатский края.

${ }^{17}$ К группе относятся: Липецкая, Орловская, Смоленская, Тамбовская области, Республика Карелия, Астраханская область, Удмуртская Республика, Самарская, Тюменская области, Республика Тыва, Чувашская Республика, Республика Алтай, Магаданская область, Республика Адыгея, Кемеровская, Сахалинская области. 
Т а б л и ц а 2. Характеристики экономического развития регионов в зависимости от количества отраслевых приоритетов

$\mathrm{T}$ a b 1 e 2 . Characteristics of the economic development of regions depending on the number of the industry priorities

\begin{tabular}{|c|c|c|c|}
\hline $\begin{array}{c}\text { Показатель социально- } \\
\text { экономического развития / } \\
\text { Indicator of socio-economic } \\
\text { development }\end{array}$ & $\begin{array}{c}\text { Первая группа } \\
\text { (наибольшее } \\
\text { количество } \\
\text { приоритетов) / } \\
\text { Group 1 } \\
\text { (maximum } \\
\text { number of } \\
\text { priorities) }\end{array}$ & $\begin{array}{c}\text { Вторая группа } \\
\text { (умеренное } \\
\text { количество } \\
\text { приоритетов) / } \\
\text { Group 2 } \\
\text { (median } \\
\text { number of } \\
\text { priorities) }\end{array}$ & $\begin{array}{c}\text { Третья группа } \\
\text { (наименьшее } \\
\text { количество } \\
\text { приоритетов) / } \\
\text { Group 3 } \\
\text { (minimum } \\
\text { number of } \\
\text { priorities) }\end{array}$ \\
\hline $\begin{array}{l}\text { Среднее количество отраслевых } \\
\text { приоритетов / Average number of in- } \\
\text { dustry priorities }\end{array}$ & 10,7 & 7,8 & 5,4 \\
\hline $\begin{array}{l}\text { Среднее значение ВРП на душу на- } \\
\text { селения, } 2015 \text { г., руб. / Average GRP } \\
\text { per capita, 2015, rubles }\end{array}$ & 351725 & 345404 & $318306^{18}$ \\
\hline $\begin{array}{l}\text { Средний темп экономического ро- } \\
\text { ста, 2005-2015 гг., \% / Average eco- } \\
\text { nomic growth rate, 2005-2015, \% }\end{array}$ & 14,2 & 15,1 & 14,3 \\
\hline $\begin{array}{l}\text { Доля регионов с городом-миллио- } \\
\text { нером, \% / Share of regions with } \\
\text { a million-plus city, \% }\end{array}$ & 33 & 22 & 12 \\
\hline $\begin{array}{l}\text { Количество регионов / Number of } \\
\text { regions }\end{array}$ & 13 & 37 & 16 \\
\hline
\end{tabular}

Все три группы регионов отличаются по набору отраслевых приоритетов. Приоритеты первой группы - это чаще всего телекоммуникационное оборудование, оптовая торговля, электронная коммерция. Во второй группе в приоритеты попали пищевая промышленность, строительство, машиностроение и туризм. Регионы третьей группы стали обладателями более ресурсно зависимых приоритетов (рыболовство и добыча угля).

В целом отраслевые приоритеты российских регионов оказались сфокусированы на наиболее общих для экономики России секторах - добывающей и обрабатывающей промышленности, сельском хозяйстве, развитии транспортной инфраструктуры. Можно предположить, что из-за недостаточной проработки конкурентных преимуществ региона заявленные приоритеты не оказывают должного эффекта на структурные перемены в регионах. Далее предпринята попытка проверить, как выбор региональных приоритетов сказался на процессах диверсификации в экономике российских регионов.

Появление новых отраслей зафиксировано в 46 регионах. Среди них чаще всего замечены производство мясной продукции, медицинского оборудования, электро-

${ }^{18}$ Без учета Магаданской и Сахалинской областей - они рассматриваются как выбросы в данной выборке. 
оборудования и осветительных приборов, мебели, офисного оборудования, товаров для досуга и др. Новые отрасли в основном относятся к производству товаров и услуг для конечного потребления, в то время как традиционные промышленные отрасли в меньшей степени подвержены возникновению в новых локациях [10].

Расчеты показали, что не везде подобная диверсификация отраслевой структуры стала следствием стратегического планирования. В 11 регионах из числа рассмотренных зафиксирована незапланированная диверсификация отсутствие связи между отраслевыми приоритетами, заявленными в региональных стратегиях, и появившимися отраслями.

Некоторые регионы с незапланированной диверсификацией характеризуются сравнительно небольшими экономиками (например, Тульская, Тамбовская, Кемеровская области), но также замечены и регионы с относительно высоким ВРП на душу населения (Пермский край, Оренбургская область). Эти регионы объединяет то, что почти все они либо находятся в непосредственной территориальной близости к региону с крупным экономическим центром страны (50 \%) либо сами обладают таковым (33 \%). Вероятно, расположение региона вблизи города-миллионера является одной из причин незапланированной диверсификации. В регионах с городом-миллионером более высокие темпы структурных изменений [10]. Эти регионы могут ориентировать экономику соседних регионов на свое развитие за счет притока инвестиций и формирования нового спроса. Такое развитие событий свидетельствует о том, что стратегическое решение региональных властей не всегда учитывает факторы, которые могут оказывать влияние на структурные преобразования внутри региона.

В 30 регионах выявлена запланированная диверсификация - наличие связи между приоритетами и новыми отраслями. В целом средний уровень экономического развития этих регионов ниже по сравнению с регионами, у которых не было определено связи между приоритетами и структурными переменами ${ }^{19}$.

Треть регионов с запланированной диверсификацией находится на удалении от крупных центров страны (например, Магаданская и Мурманская области). Вероятно, влияние «волн» структурных перемен, исходящих от регионов с городом-миллионером, носит ограниченный характер на отраслевое развитие отдаленных регионов, что в свою очередь не нарушает запланированного развития. В регионах с крупной агломерацией наличие связи приоритетов и новых отраслей встречалось реже (например, в Самарской и Волгоградской областях). Можно предположить, что структурные перемены в таких регионах более стихийны и менее предсказуемы и, следовательно, хуже учитываются при долгосрочном стратегическом планировании.

Если сопоставить общее количество приоритетных отраслей с количеством связанных с ними новых отраслей у всех регионов, у которых была определена запланированная диверсификация, то открывается следующая картина (рис. 3).

${ }^{19}$ Среднее ВРП на душу населения у регионов, у которых обнаружена связь, составляет 320480 руб. (исключая значения по Санкт-Петербургу и Магаданской области как выбросы); у регионов, у которых не обнаружена связь, значение составляет 335133 руб. 
Владимирская область / Vladimir Region

Ростовская область / Rostov Region

Республика Башкортостан / Republic of Bashkortostan

Омская область / Omsk Region

г. Санкт-Петербург / City of St. Petersburg

Ульяновская область / Ulyanovsk Region

Вологодская область / Vologda Region

Новгородская область / Novgorod Region

Кировская область / Kirov Region

Калужская область / Kaluga Region

Ленинградская область / Leningrad Region

Новосибирская область / Novosibirsk Region

Саратовская область / Saratov Region

Республика Марий Эл / Republic of Mari El

Челябинская область / Chelyabinsk Region

Белгородская область / Belgorod Region

Московская область / Moscow Region

Псковская область / Pskov Region

Республика Дагестан / Republic of Dagestan

Алтайский край / Altai Territory

Приморский край / Primorye Territory

Воронежская область / Voronezh Region

Ивановская область / Ivanovo Region

Мурманская область / Murmansk Region

Амурская область / Amur Region

Удмуртская Республика / Udmurt Republic

Астраханская область / Astrakhan Region

Смоленская область / Smolensk Region

Чувашская Республика / Chuvash Republic

Магаданская область / Magadan Region

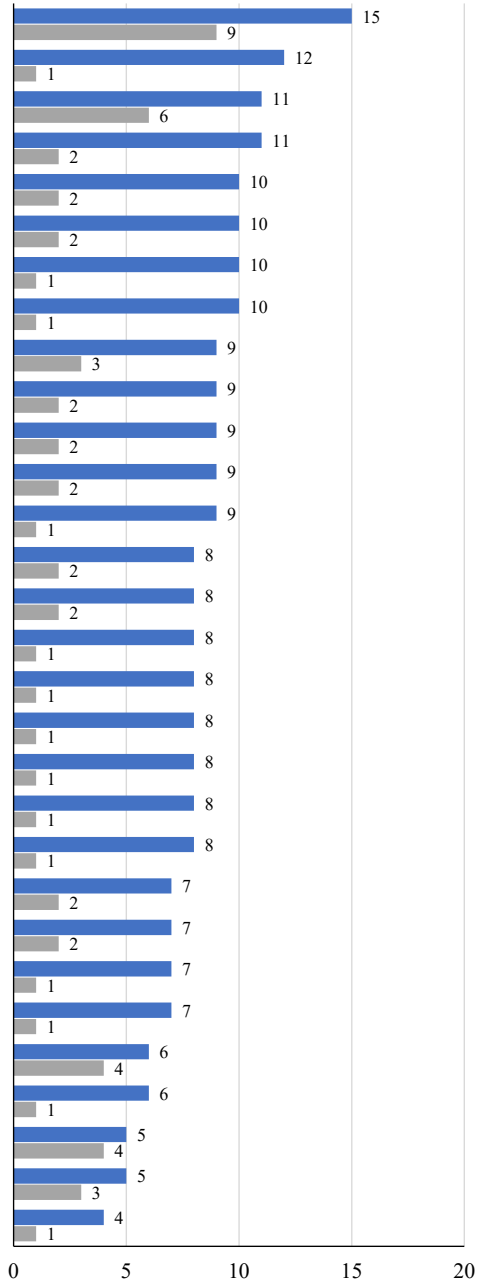

- Количество заявленных приоритетов / Number of the declared priorities

- Количество заявленных приоритетов, связанных с новыми отраслями / Number of the declared priorities related to new industries

Р и с. 3. Связанность заявленных отраслевых приоритетов и новых отраслей в российских регионах

F i g. 3. Correlation between the declared industry priorities and new industries in Russia's regions 
Анализ показал, что большая часть появившихся отраслей имеет связь с приоритетами только в 5 регионах: Башкортостане, Удмуртии, Чувашии, Смоленской и Владимирской областях. Во всех остальных случаях в среднем только одна новая отрасль оказалась связана с приоритетами региона. Большую часть таких регионов составляют либо те, что соседствуют с крупными агломерациями, либо сами крупные агломерации. Таким образом, в российских регионах широко распространена незапланированная диверсификация стратегическое решение региональных властей не оказывает должного влияния на структурные трансформации.

Результатом структурных перемен может стать появление отраслей, которые не связаны со сложившимся отраслевым портфелем региона и развитие которых требует радикально новых квалификаций и капитала, что может быть не предусмотрено долгосрочной стратегией развития. В 22 регионах появились отрасли, которые оказались несвязанными с их отраслевой структурой. Из них в 10 регионах не было зафиксировано влияния отраслевых приоритетов. Так, в Липецкой, Иркутской, Тамбовской областях происходили процессы структурных перемен, в результате которых появились совершенно новые для региона специализации и к которым регионы, вероятно, не подготовились на уровне стратегического планирования.

Скорее всего, появление несвязанных со структурой экономики отраслей определяется не решением региональных властей. Напротив, региональные власти выбирают в качестве приоритетного связанный путь развития. Так, в регионах с запланированной диверсификацией новые отрасли оказались связанными со структурой экономики.

В целом исследование показывает, что отраслевые приоритеты не влияют на отраслевое развитие российских регионов. Такой результат можно трактовать как упущение при выборе приоритетов других факторов, которые воздействуют на отраслевое развитие, в отличии от утвержденного целевого стратегического планирования. Вероятно, это связано с отсутствием единообразного и более комплексного подхода к формированию отраслевых приоритетов на уровне региона. Полученный вывод встраивается в дискуссию о качестве формирования отраслевых приоритетов и стратегического планирования в целом.

Обсуждение и заключение. Стратегическое планирование охватывает широкий спектр перспектив и возможностей для обеспечения устойчивого развития региональной экономики. Для России вопросы долгосрочного планирования имеют актуальное значение, учитывая существенную дифференциацию в социально-экономическом развитии регионов. Региональные власти формируют цели и задачи социально-экономического развития на долгосрочную перспективу, определяют приоритетные индустрии и формируют соответствующие меры поддержки. При разработке стратегических документов региональные власти указывают на необходимость диверсификации региональной экономики и ускоренного развития важнейших секторов 
для региона. Однако достижению поставленных задач препятствует низкое качество проработки конкурентных преимуществ при формировании приоритетов отраслевого развития.

Анализ региональных стратегий показал, что заявленные отраслевые приоритеты субъектов Федерации не отражают уникальных специализаций региона, а сфокусированы на наиболее общих для экономики России секторах. Большинство регионов выбрало в качестве приоритетных индустрий добывающую и обрабатывающую промышленность, сельское хозяйство или развитие транспортной инфраструктуры. Отсутствие комплексного подхода к обоснованному выбору отраслевых приоритетов сказывается на том, что диверсификация региональной экономики становится незапланированной.

Настоящее исследование показывает, что диверсификация экономики в российских регионах - это не решение региональных органов власти, а результат воздействия неучтенных при стратегическом планировании значимых факторов, как, например, близость к крупным агломерациям.

Вследствие незапланированной диверсификации во многих регионах появляются отрасли, которые не связаны с отраслевой структурой региональной экономики. Для их развития требуются радикально новые квалификации и капитал, а также меры поддержки, которые не предусматриваются на уровне региональных стратегических документов.

Выводы исследования формируют теоретические основания для выработки единого, актуализируемого и комплексного подхода к формированию отраслевых приоритетов с целью предотвращения дублирования содержания региональных документов, оптимизации распределения ресурсов, повышения эффективности использования бюджетных средств и избегания фрагментации мер государственной поддержки. Результаты исследования могут быть полезны региональным органам исполнительной власти при формировании документов долгосрочного стратегического планирования. Полученные выводы также способствуют расширению теоретической базы государственного и муниципального управления в части оценки влияния стратегических документов на развитие региональной экономики.

\section{СПИСОК ИСПОЛЬЗОВАННЫХ ИСТОЧНИКОВ}

1. Clark, G. The Future of Cities: The Role of Strategic Planning / G. Clark. - DOI 10.24023/FutureJournal/2175-5825/2013.v5i1.140 // Future Studies Research Journal: Trends and Strategy. - 2013. - Vol. 5, no 1. - Pp. 3-32. - URL: https://www.revistafuture. org/FSRJ/article/view/140 (дата обращения: 10.02.2020).

2. Nieboer, N. Strategic Planning Process Models: A Step Further / N. Nieboer. - DOI 10.1108/02637471111154818 // Property Management. - 2011. Vol. 29, no. 4. - Pp. 371-382. - URL: https://www.emerald.com/insight/content/ doi/10.1108/02637471111154818/full/html (дата обращения: 10.02.2020). 
3. Ocasio, W. Rise and Fall - or Transformation?: The Evolution of Strategic Planning at the General Electric Company, 1940-2006 / W. Ocasio, J. Joseph. - DOI 10.1016/j. lrp.2008.02.010 // Long Range Planning. - 2008. - Vol. 4, issue 3. - Pp. 248-272. - URL: https://www.sciencedirect.com/science/article/pii/S0024630108000265?via\%3Dihub (дата обращения: 10.02.2020).

4. Kotler, P. Marketing Management / P. Kotler, K. L. Keller. - New Jersey : Pearson, Prentice Hall, 2006. - 729 p. - URL: http://eprints.stiperdharmawacana.ac.id/24/1/\%5BPhillip_Kotler\%5D_Marketing_Management_14th_Edition\%28BookFi\%29.pdf (дата обращения: 10.02.2020).

5. Doyle, P. Value-Based Marketing: Marketing Strategies for Corporate Growth and Shareholder Value / P. Doyle. - Chichester ; New York : John Wiley \& Son, 2000. - 384 p. URL: https://www.academia.edu/11844146/Marketing_Value_Based_Marketing_Marketing Strategies for Corporate Growth and Shareholder Value?auto=download (дата об-

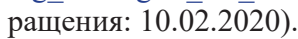

6. Fifield, P. Marketing Strategy: The Difference between Marketing and Markets / P. Fifield. - Third Edition. - Amsterdam ; Boston : Elsevier / Butterworth-Heinemann, 2007. 316 p. - URL: https://openlibrary.org/books/OL18028475M/Marketing strategy (дата обращения: 10.02.2020).

7. Tsenkova, S. Urban Futures: Strategic Planning in Post-Socialist Europe / S. Tsenkova. - DOI 10.1007/978-1-4020-6053-3_22 // The Post-Socialist City: Urban Form and Space Transformations in Central and Eastern Europe after Socialism / K. Stanilov (eds.). - The GeoJournal Library. - Vol. 92. - Dordrecht : Springer, 2007. - Pp. 447-471. - URL: https:// link.springer.com/chapter/10.1007/978-1-4020-6053-3_22 (дата обращения: 15.02.2020).

8. Quatraro, F. Knowledge Coherence, Variety and Economic Growth: Manufacturing Evidence from Italian Regions / F. Quatraro. - DOI 10.1016/j.respol.2010.09.005 // Research Policy. - 2010. - Vol. 39, issue 10. - Pp. 1289-1302. - URL: https://www.sciencedirect.com/science/article/abs/pii/S0048733310001952 (дата обращения: 15.02.2020).

9. Neffke, F. How do Regions Diversify Over Time? Industry Relatedness and the Development of New Growth Paths in Regions / F. Neffke, M. Henning, R. Boschma. DOI 10.1111/j.1944-8287.2011.01121.x // Economic Geography. - 2011. - Vol. 87, issue 3. - Pp. 237-265. - URL: https://onlinelibrary.wiley.com/doi/abs/10.1111/j.19448287.2011.01121.x (дата обращения: 15.02.2020).

10. Kutsenko, E. "Whirlpools" and "Safe Harbors" in the Dynamics of Industrial Specialization in Russian Regions / E. Kutsenko, Y. Eferin. - DOI 10.17323/25002597.2019.3.24.40 // Foresight and STI Governance. - 2019. - Vol. 13, no 3. - Pp. 24-40. URL: https://foresight-journal.hse.ru/data/2019/10/14/1543331770/3-Kutsenko-24-40.pdf (дата обращения: 20.02.2020).

11. Ketels, C. Methodology and Findings Report for a Cluster Mapping of Related Sectors / C. Ketels, S. Protsiv. - Stockholm : Stockholm School of Economics, 2014. - 41 p. URL: https://ec.europa.eu/docsroom/documents/16527/attachments/1/translations/en/renditions/native (дата обращения: 20.02.2020).

12. Hafner, K. A. Growth-Instability Frontier and Industrial Diversification: Evidence from European Gross Value Added / K. A. Hafner. - DOI 10.1111/pirs.12401 // Papers in Regional Science. - 2019. - Vol. 98, no. 2. - Pp. 799-824. - URL: https://rsaiconnect.onlinelibrary.wiley.com/doi/full/10.1111/pirs.12401 (дата обращения: 20.02.2020). 
13. Fitjar, R. D. Knowledge Bases and Relatedness: A Study of Labour Mobility in Norwegian Regions / R. D. Fitjar, B. Timmermans. - DOI 10.1007/978-3-319-71661-9_8 // New Avenues for Regional Innovation Systems - Theoretical Advances, Empirical Cases and Policy Lessons / A. Isaksen, R. Martin, M. Trippl (eds.). - Cham : Springer, 2018. Pp. 149-171. - URL: https://link.springer.com/chapter/10.1007\%2F978-3-319-71661-9_8 (дата обращения: 20.02.2020).

14. Kogler, D. F. Relatedness as Driver of Regional Diversification: A Research Agenda - A Commentary / D. F. Kogler. - DOI 10.1080/00343404.2016.1276282 // Regional Studies. - 2017. - Vol. 51, no. 3. - Pp. 365-369. - URL: https:/www.tandfonline.com/doi/ full/10.1080/00343404.2016.1276282 (дата обращения: 20.02.2020).

15. Diodato, D. The Resilience of Regional Labour Markets to Economic Shocks: Exploring the Role of Interactions Among Firms and Workers / D. Diodato, A. B. R. Weterings. DOI 10.1093/jeg/lbu030 // Journal of Economic Geography. - 2015. - Vol. 15, no. 4. Pp. 723-742. - URL: https://academic.oup.com/joeg/article-abstract/15/4/723/2412444?redirectedFrom=fulltext (дата обращения: 20.02.2020).

16. Karlsson, C. Geographies of Growth Innovations, Networks and Collaborations - New Horizons in Regional Science / C. Karlsson, M. Andersson, L. Bjerke. - DOI 10.4337/9781785360602. - Cheltenham ; Northampton : Edward Elgar, 2017. - 460 p. - URL: https://www.elgaronline.com/view/edcoll/9781785360596/9781785360596.xml (дата обращения: 20.02.2020).

17. Gavriilidis, G. Strategic Planning and City / Regional Development: Review, Analysis, Critique and Applications for Greece / G. Gavriilidis, Th. Metaxas. - Munich, 2017. URL: https://mpra.ub.uni-muenchen.de/81131/1/MPRA paper_81131.pdf (дата обращения: 24.02.2020).

18. Using Scenario Planning in Regional Development Context: The Challenges and Opportunities / B. Edgar, A. Abouzeedan, T. Hedner [et al.]. - DOI 10.1108/20425941311323118 // World Journal of Science, Technology and Sustainable Development. - 2013. - Vol. 10, no. 2. - Pp. 103-122. - URL: https://www.emerald.com/ insight/content/doi/10.1108/20425941311323118/full/html (дата обращения: 24.02.2020).

19. Hansson, A. G. Promoting Planning for Housing Development: What Can Sweden Learn from Germany? / A. G. Hansson. - DOI 10.1016/j.landusepol.2017.03.012 // Land Use Policy. - 2017. - Vol. 64. - Pp. 470-478. - URL: https://www.sciencedirect.com/science/article/abs/pii/S0264837716301995 (дата обращения: 24.02.2020).

20. De Montis, A. Impacts of the European Landscape Convention on National Planning Systems: A Comparative Investigation of Six Case Studies / A. De Montis. - DOI 10.1016/j. landurbplan.2014.01.005 // Landscape and Urban Planning. - 2014. - Vol. 124. - Pp. 53-65. URL: https://www.sciencedirect.com/science/article/abs/pii/S0169204614000061 (дата обращения: 24.02.2020).

21. Mondragón-Ixtlahuac, M. A Strategic Planning Model for the Passenger Rail Implementation Process: The Case of Mexico / M. Mondragón-Ixtlahuac, J. Cortés-Martínez, D. Delgado-Hernández. - DOI 10.1016/j.tranpol.2017.01.004 // Transport Policy. - 2017. Vol. 55. - Pp. 29-37. - URL: https://www.sciencedirect.com/science/article/pii/S0967070X16302001?via\%3Dihub (дата обращения: 24.02.2020).

22. Концептуальные подходы к формированию архитектуры документов стратегического планирования в России / О. О. Смирнова, Л. К. Бочарова, Л. А. БеляевскаяПлотник, Ю. Н. Богданова. - DOI 10.18184/2079-4665.2019.10.4.440-456 // МИР (Мо- 
дернизация. Инновации. Развитие). - 2019. - Т. 10. - № 4. - C. 440-456. - URL: https:// www.mir-nayka.com/jour/article/view/971/863 (дата обращения: 01.03.2020). - Рез. англ.

23. Климанов, В. В. Механизмы формирования стратегических приоритетов социально-экономического развития / В. В. Климанов, Н. А. Чернышова, Д. А. Недопивцева // Мир экономики и управления. - 2016. - № 4. - С. 80-92. - URL: https:// cyberleninka.ru/article/n/mehanizmy-formirovaniya-strategicheskih-prioritetov-sotsialnoekonomicheskogo-razvitiya (дата обращения: 05.03.2020). - Рез. англ.

24. Добролюбова, Е. И. Анализ региональной нормативно-правовой базы, регламентирующей вопросы разработки и реализации государственных программ / Е. И. Добролюбова, Е. И. Клочкова. - DOI 10.21686/2500-3925-2015-6-70-75 // Статистика и экономика. - 2015. - № 6. - C. 70-75. - URL: https://statecon.rea.ru/jour/article/ view/858 (дата обращения: 15.05.2020). - Рез. англ.

25. Южаков, В. Н. Государственное управление по результатам: модель для России / В. Н. Южаков // Вопросы государственного и муниципального управления. 2016. - № 2. - C. 165-174. - URL: https:/vgmu.hse.ru/2016--2/185040695.html (дата обращения: 15.03.2020). - Рез. англ.

26. Климанов, В. В. Точки роста как элемент стратегического планирования в регионах России / В. В. Климанов, К. В. Будаева // Региональные исследования. - 2017. № 3. - C. 99-106. - URL: http://media.geogr.msu.ru/RI/RI_2017_03(57).pdf (дата обращения: 15.03.2020). - Рез. англ.

27. Ulyanova, E. A. Development of Regional Strategies in Russia: The Case of Sverdlovsk Region / E. A. Ulyanova. - DOI 10.15826/recon.2017.3.3.020 // R-Economy. 2013. - Vol. 3, issue 3. - Pp. 176-188. - URL: https://journals.urfu.ru/index.php/r-economy/ article/view/2974 (дата обращения: 15.03.2020).

28. Куценко, Е. С. Фокусировка региональной промышленной политики через отраслевую специализацию / Е. С. Куценко, В. Л. Абашкин, Е. А. Исланкина. - DOI 10.32609/0042-8736-2019-5-65-89 // Вопросы экономики. - 2019. - № 5. - С. 65-89. - URL: https://www.vopreco.ru/jour/article/view/2203 (дата обращения: 15.03.2020). - Рез. англ.

29. Delgado, M. Defining Clusters of Related Industries / M. Delgado, M. E. Porter, S. Stern. - DOI 10.1093/jeg/lbv017 // Journal of Economic Geography. - 2016. - Vol. 16, issue 1.-Pp. 1-38. -URL: https://academic.oup.com/joeg/article-abstract/16/1/1/2413044?redirectedFrom=fulltext (дата обращения: 17.03.2020).

Поступила 09.11.2020; одобрена после рецензирования 29.01.2021; принята к публикации 08.02.2021.

\section{Об авторе:}

Еферин Ярослав Юрьевич, аспирант Института статистических исследований и экономики знаний ФГАОУ ВО «Национальный исследовательский университет «Высшая школа экономики» (101000, Российская Федерация, г. Москва, ул. Мясницкая, д. 20), аналитик Глобальной практики по цифровому развитию Всемирного банка (121069, Российская Федерация, г. Москва, ул. Большая Молчановка, д. 36/1), ORCID: https://orcid.org/0000-0003-4132-2033,yeferin@worldbank.org

Автор и его научный руководитель прочитали и одобрили окончательный вариант рукописи. 


\section{REFERENCES}

1. Clark G. The Future of Cities: The Role of Strategic Planning. Future Studies Research Journal: Trends and Strategy. 2013; 5(1):3-32. (In Eng.) DOI: https://doi.org/10.24023/FutureJournal/2175-5825/2013.v5i1.140

2. Nieboer N. Strategic Planning Process Models: A Step Further. Property Management. 2011; 29(4):371-382. (In Eng.) DOI: https://doi.org/10.1108/02637471111154818

3. Ocasio W., Joseph J. Rise and Fall - or Transformation?: The Evolution of Strategic Planning at the General Electric Company, 1940-2006. Long Range Planning. 2008; 4(3):248-272. (In Eng.) DOI: https://doi.org/10.1016/j.lrp.2008.02.010

4. Kotler P., Keller K.L. Marketing Management. New Jersey: Pearson, Prentice Hall; 2006. Available at: http://eprints.stiperdharmawacana.ac.id/24/1/\%5BPhillip_Kotler\%5D Marketing_Management 14th_Edition\%28BookFi\%29.pdf (accessed 10.02.2020). (In Eng.)

5. Doyle P. Value-Based Marketing: Marketing Strategies for Corporate Growth and Shareholder Value. Chichester; New York: John Wiley \& Son; 2000. Available at: https:// www.academia.edu/11844146/Marketing_Value_Based_Marketing_Marketing_Strategies for_Corporate_Growth_and_Shareholder_Value? $\bar{a}$ auto $=\overline{\text { download }}$ (accessed 10.02 .2020$)$. (In Eng.)

6. Fifield P. Marketing Strategy: The Difference between Marketing and Markets. Third Edition. Amsterdam; Boston: Elsevier / Butterworth-Heinemann; 2007. Available at: https://openlibrary.org/books/OL18028475M/Marketing_strategy (accessed 10.02.2020). (In Eng.)

7. Tsenkova S. Urban Futures: Strategic Planning in Post-Socialist Europe. In: The Post-Socialist City: Urban Form and Space Transformations in Central and Eastern Europe after Socialism / K. Stanilov (eds.). 2007; 92:447-471. (In Eng.) DOI: https://doi.org/10.1007/978-14020-6053-3 22

8. Quatraro F. Knowledge Coherence, Variety and economic Growth: Manufacturing Evidence from Italian Regions. Research Policy. 2010; 39(10):1289-1302. (In Eng.) DOI: https://doi.org/10.1016/j.respol.2010.09.005

9. Neffke F., Henning M., Boschma R. How do Regions Diversify over Time? Industry Relatedness and the Development of new Growth Paths in Regions. Economic Geography. 2011; 87(3):237-265. (In Eng.) DOI: https://doi.org/10.1111/j.1944-8287.2011.01121.x

10. Kutsenko E., Eferin Y. "Whirlpools" and "Safe Harbors" in the Dynamics of Industrial Specialization in Russian Regions. Foresight and STI Governance. 2019; 13(3):24-40. (In Eng.) DOI: https://doi.org/10.17323/2500-2597.2019.3.24.40

11. Ketels C., Protsiv S. Methodology and Findings Report for a Cluster Mapping of Related Sectors. Stockholm: Stockholm School of Economics; 2014. Available at: https:// ec.europa.eu/docsroom/documents/16527/attachments/1/translations/en/renditions/native (accessed 20.02.2020). (In Eng.)

12. Hafner K.A. Growth-Instability Frontier and Industrial Diversification: Evidence from European Gross Value Added. Papers in Regional Science. 2019; 98(2):799-824. (In Eng.) DOI: https://doi.org/10.1111/pirs.12401

13. Fitjar R.D., Timmermans B. Knowledge Bases and Relatedness: A Study of Labour Mobility in Norwegian Regions. In: New Avenues for Regional Innovation Systems - Theoretical Advances, Empirical Cases and Policy Lessons. Cham: Springer; 2018. p. 149-171. (In Eng.) DOI: https://doi.org/10.1007/978-3-319-71661-9_8 
14. Kogler D.F. Relatedness as Driver of Regional Diversification: A Research Agenda A Commentary. Regional Studies. 2017; 51(3):365-369. (In Eng.) DOI: https://doi.org/10.1 080/00343404.2016.1276282

15. Diodato D., Weterings A.B.R. The Resilience of Regional Labour Markets to Economic Shocks: Exploring the Role of Interactions Among Firms and Workers. Journal of Economic Geography. 2015; 15(4):723-742. (In Eng.) DOI: https://doi.org/10.1093/jeg/lbu030

16. Karlsson C., Andersson M., Bjerke L. Geographies of Growth Innovations, Networks and Collaborations - New Horizons in Regional Science. Cheltenham; Northampton: Edward Elgar; 2017. (In Eng.) DOI: https://doi.org/10.4337/9781785360602

17. Gavriilidis G., Metaxas Th. Strategic Planning and City / Regional Development: Review, Analysis, Critique and Applications for Greece. Munich; 2017. Available at: https://mpra. ub.uni-muenchen.de/81131/1/MPRA_paper_81131.pdf (accessed 24.02.2020). (In Eng.)

18. Edgar B., Abouzeedan A., Hedner T., et al. Using Scenario Planning in Regional Development Context: the Challenges and Opportunities. World Journal of Science, Technology and Sustainable Development. 2013; 10(2):103-122. (In Eng.) DOI: https://doi. org/10.1108/20425941311323118

19. Hansson A.G. Promoting Planning for Housing Development: What Can Sweden Learn from Germany? Land Use Policy. 2017; 64:470-478. (In Eng.) DOI: https://doi. org/10.1016/j.landusepol.2017.03.012

20. De Montis A. Impacts of the European Landscape Convention on National Planning Systems: A Comparative Investigation of Six Case Studies. Landscape and Urban Planning. 2014; 124:53-65. (In Eng.) DOI: https://doi.org/10.1016/j.landurbplan.2014.01.005

21. Mondragón-Ixtlahuac M., Cortés-Martínez J., Delgado-Hernández D. A Strategic Planning Model for the Passenger Rail Implementation Process: The Case of Mexico. Transport Policy. 2017; 55:29-37. (In Eng.) DOI: https://doi.org/10.1016/j.tranpol.2017.01.004

22. Smirnova O.O., Bocharova L.K., Belyaevskaya-Plotnik L.A., Bogdanova Ju.N. Conceptual Approaches to the Formation of Architecture of Documents of Strategic Planning in Russia. MIR (Modernizatsiya. Innovatsii. Razvitie) = MIR (Modernization. Innovation. Research). 2019; 10(4):440-456. (In Russ., abstract in Eng.) DOI: https://doi. org/10.18184/2079-4665.2019.10.4.440-456

23. Klimanov V.V., Chernyshova N.A., Nedopivtseva D.A. The Mechanisms of Formation of Strategic Socio-Economic Priorities. Mir ehkonomiki i upravleniya $=$ World of Economics and Management. 2016; (4):80-92. Available at: https://cyberleninka.ru/article/n/ mehanizmy-formirovaniya-strategicheskih-prioritetov-sotsialno-ekonomicheskogo-razvitiya (accessed 05.03.2020). (In Russ., abstract in Eng.)

24. Dobrolyubova E.I., Klochkova E.N. Analysis of the Regional Legal Base Regulating Development and Implementation of Public Programs. Statistika $i$ ehkonomika $=$ Statistics and Economics. 2015; (6):70-75. (In Russ., abstract in Eng.) DOI: https://doi. org/10.21686/2500-3925-2015-6-70-75

25. Yuzhakov V.N. Result-Based Public Management: The Russian Model. Voprosy gosudarstvennogo $i$ municipalnogo upravleniya $=$ Public Administration Issues. 2016; (2):165-174. Available at: https://vgmu.hse.ru/2016--2/185040695.html (accessed 15.03.2020). (In Russ., abstract in Eng.)

26. Klimanov V.V., Budaeva K.V. Points of Growth as an Element of Strategic Planning in Russia's Regions. Regionalnye issledovaniya = Regional Studies. 2017; (3):99-106. 
Available at: http://media.geogr.msu.ru/RI/RI_2017_03(57).pdf (accessed 15.03.2020). (In Russ., abstract in Eng.)

27. Ulyanova E.A. Development of Regional Strategies in Russia: the Case of Sverdlovsk Region. R-Economy. 2013; 3(3):176-188. (In Eng.) DOI: https://doi.org/10.15826/ recon.2017.3.3.020

28. Kutsenko E.S., Abashkin V.L., Islankina E.A. Focusing Regional Industrial Policy via Sectorial Specialization. Voprosy ehkonomiki = Economic Issues. 2019; (5):65-89. (In Russ., abstract in Eng.) DOI: https://doi.org/10.32609/0042-8736-2019-5-65-89

29. Delgado M., Porter M.E., Stern S. Defining Clusters of Related Industries. Journal of Economic Geography. 2016; 16(1):1-38. (In Eng.) DOI: https://doi.org/10.1093/jeg/lbv017

Submitted 09.11.2020; approved after reviewing 29.01.2021; accepted for publication 08.02.2021.

About the author:

Yaroslav Yu. Eferin, Postgraduate, Institute for Statistical Studies and Economics of Knowledge, National Research University Higher School of Economics (20 Myasnitskaya St., Moscow 101000, Russian Federation); Analyst, Digital Development Global Practice, World Bank (36/1 Bolshaya Molchanovka St., Moscow 121069, Russian Federation), ORCID: https://orcid.org/0000-0003-4132-2033, yeferin@worldbank.org

The author and his academic supervisor have read and approved the final version of the manuscript. 


\section{Стратегическое управление устойчивым развитием предприятий малого бизнеса}

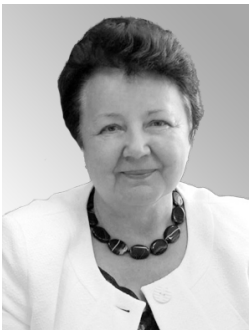

Н. Д. Гуськова ${ }^{1}$

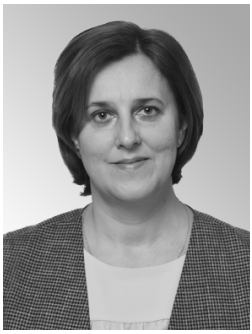

А. В. Ерастова ${ }^{1^{*}}$

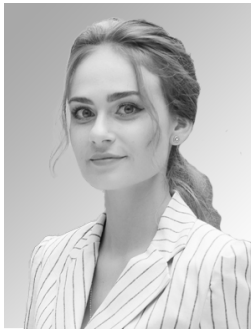

Д. В. Никитина ${ }^{2}$

${ }^{1}$ ФГБОУ ВО «МГУ им. Н. П. Огарёва» (г. Саранск, Российская Федераџия), erastova.74@inbox.ru

2 Агентство «СберМаркетинг» (2. Москва, Российская Федерация)

Введение. Глобализация экономики, формирование концепции устойчивого развития во многом определяют стратегию продвижения организаций как крупного, так и малого бизнеса. Следование принципам устойчивого развития становится для предприятий обязательным условием для повышения конкурентоспособности и привлекательности для стейкхолдеров. Цель статьи - на основе проведенного исследования разработать этапы формирования стратегического управления устойчивым развитием предприятий малого бизнеса.

Материалы и методы. На примере компании АО «Лидер-Компаунд» проведен анализ финансово-экономической, экологической и социальной составляющих устойчивости предприятия. Материалами исследования послужили отчетность организации за 2012-2019 гг. и результаты проведенного анкетирования руководящего состава. Экспертным методом определена итоговая оценка соответствия АО «Лидер-Компаунд» особенностям стратегического управления устойчивым развитием малых и средних предприятий. Использование метода стратегического анализа (SWOT-анализа) позволило выявить сильные и слабые стороны компании, а также угрозы и возможности.

Результаты исследования. Результаты комплексного анализа составляющих устойчивого развития компании позволили провести итоговую оценку соответствия данного предприятия особенностям стратегического управления малыми и средними компаниями. Установлен достаточно высокий уровень развития стратегического управления АО «Лидер-Компаунд», определены резервы для его повышения. Предложен алгоритм процесса разработки и реализации стратегии в области устойчивого развития компании. Для каждого этапа процесса обоснованы методические рекомендации по его выполнению. Для расчета обобщенного интегрального показателя уровня устойчивого развития разработана математическая модель, учитывающая составляющие устойчивого развития предприятия.

(C) Гуськова Н. Д., Ерастова А. В., Никитина Д. В., 2021 Контент доступен под лицензией Creative Commons Attribution 4.0 License. This work is licensed under a Creative Commons Attribution 4.0 License. 
Обсуждение и заключение. Предложенный процесс разработки и реализации стратегии устойчивого развития малого предприятия позволит не только сформировать обоснованную по составляющим устойчивого развития стратегию, но и обеспечить возможность ее успешной реализации. Результаты исследования могут быть использованы как в практической деятельности других малых предприятий, так и в дальнейшем научном исследовании особенностей управления устойчивым развитием малых предприятий других сфер деятельности.

Ключевые слова: устойчивое развитие, стратегия устойчивого развития, малое предприятие, составляющие устойчивого развития, оценка уровня устойчивого развития

Авторы заявляют об отсутствии конфликта интересов.

Для циитирования: Гуськова, Н. Д. Стратегическое управление устойчивым развитием предприятий малого бизнеса / Н. Д. Гуськова, А. В. Ерастова, Д. В. Никитина. - DOI 10.15507/2413-1407.115.029.202102.306-327 // Регионология. - 2021. - Т. 29, № 2. C. 306-327.

\title{
Strategic Management of Sustainable Development of Small Business Enterprises
}

\author{
N. D. Guskova ${ }^{1}$, A. V. Erastova ${ }^{1 *}$, D. V. Nikitina ${ }^{2}$ \\ ${ }^{1}$ National Research Mordovia State University (Saransk, Russian Federation), \\ "erastova.74@inbox.ru \\ 2 SberMarketing Agency
}

Introduction. The globalization of the economy and the introduction of the concept of sustainable development largely determine the development strategy of both large and small businesses. Adherence to the principles of sustainable development is becoming a prerequisite for organizations to develop, increase competitiveness and attractiveness for stakeholders. The purpose of the study is to elaborate the stages of formation of strategic management of sustainable development of small business enterprises.

Materials and Methods. An analysis of the financial, economic, environmental and social components of sustainability of JSC Leader-Compound was performed as a case study. The company's financial statements for 2012-2019 as well as the results of the survey conducted among the management staff were used as the materials for the study. The expert method was employed to determine the final assessment of compliance of JSC Leader-Compound with the features of strategic management of sustainable development of small and medium-sized enterprises. The employed method of strategic analysis (SWOT analysis) made it possible to identify the strengths and weaknesses of the company, as well as threats and opportunities.

Results. The results of a comprehensive analysis of the components of sustainable development of JSC Leader-Compound made it possible to conduct a final assessment of the compliance of this enterprise with the features of strategic management of small and medium-sized businesses. A sufficiently high level of development of the strategic management of JSC Leader-Compound has been noted, and reserves for its improvement have been determined. An algorithm for the process of development and implementation of a strategy for sustainable development of the company has been proposed. Methodological recommendations have been substantiated for each stage of the process. To calculate the generalized integral indicator of the level of sustainable development, a mathematical model has been proposed that takes into account the components of sustainable development of the company. 
Discussion and Conclusion. The proposed process of development and implementation of a strategy for sustainable development of a small business will make it possible not only to form a strategy based on the components of sustainable development, but also to ensure the possibility of its successful implementation. The research results may contribute to both practical activities of other small businesses, and further scientific research of the features of managing the sustainable development of small enterprises in other lines of business.

Keywords: sustainable development, sustainable development strategy, small business, components of sustainable development, assessment of the level of sustainable development

The authors declare that there is no conflict of interest.

For citation: Guskova N.D., Erastova A.V., Nikitina D.V. Strategic Management of Sustainable Development of Small Business Enterprises. Regionology = Russian Journal of Regional Studies. 2021; 29(2):306-327. DOI: https://doi.org/10.15507/24131407.115.029.202102.306-327

Введение. Устойчивое развитие отвечает потребностям людей в настоящее время и создает лучшее будущее для следующих поколений, а его составляющие (экономическая, экологическая, социальная) должны быть органично встроены в стратегическое управление предприятием [1;2]. Однако следует отметить, что традиционные подходы к стратегическому управлению предприятиями малого бизнеса не всегда применимы в силу особенностей их функционирования и взаимодействия с внешним окружением [3].

Малый бизнес в современной России имеет огромное значение для развития страны. Вместе с тем эффективное функционирование и развитие субъектов малого предпринимательства напрямую зависит от совокупности экономических, политических, социокультурных, экологических и технологических особенностей хозяйствования в регионе [4; 5], а также от уровня стратегического управления устойчивым развитием данных предприятий. Определение стратегических факторов, прогнозирование их влияния на устойчивое развитие субъектов малого бизнеса и перспективы того или иного вида предпринимательской деятельности становятся необходимым условием не только выживания, но и успешного развития предприятий данной сферы экономики страны ${ }^{1}$.

Все вышеизложенное свидетельствует об актуальности исследования. Цель статьи - определить инструменты и методы формирования этапов стратегического управления устойчивым развитием предприятий малого бизнеса.

Обзор литературы. Идея необходимости устойчивого развития социальноэкономических систем возникла на основе теории ноосферы и нашла отражение в научных кругах членов Римского клуба - неправительственной организации, созданной в 1968 г. под руководством А. Печчеи ${ }^{2}$, а также в концепции устойчивого развития, базирующейся на теории роста Я. Тинбергена ${ }^{3}$. Началом

${ }^{1}$ The Global Sustainability Competitiveness Index 2020 [Электронный pecypc]. URL: https:// solability.com/the-global-sustainable-competitiveness-index/the-index (дата обращения: 18.06.2020).

${ }^{2}$ Римский клуб. Декларация. Миссия // Вопросы философии. 1995. № 3. С. 65-72.

${ }^{3}$ Тинберген Я., Босс Х. Математические модели экономического роста. М.: Прогресс, 1967. 176 с. 
активного формирования концепции устойчивого развития послужила выдвинутая американскими учеными Д. Форрестером и Д. Медоузом теория пределов роста ${ }^{4}$. М. Клавинс, У. Леал Фильо и Я. Залокснис в своей монографии подробно рассматривают проблемы взаимосвязи составляющих устойчивого развития: окружающей среды, производства и человека, формирования системы ценностей и необходимости образования в области устойчивого развития для будущего [6]. Наиболее современное осмысление проблемы устойчивого развития прибрело на 70-й Генеральной Ассамблее ООН в рамках Саммита по устойчивому развитию в 2015 г. На ней был принят официальный документ «Преобразование нашего мира: Повестка дня в области устойчивого развития на период до 2030 года», которая включает 17 глобальных целей устойчивого развития ${ }^{5}$. Белорусские ученые С. А. Зенченко и Н. Н. Горбачев рассматривают влияние концепции устойчивого развития в странах Европейского союза, а также вопросы управления организациями на основе международных стандартов экологического менеджмента ${ }^{6}$. Вопросы влияния малого бизнеса на устойчивое развитие экономики исследуются такими учеными, как А. Сейсенбаева, Н. Гумар, М. Имрамзиева [3] и другими авторами.

В государственной политике Российской Федерации в сфере социальноэкономического развития страны положения концепции устойчивого развития также находят адекватное отражение. Так, еще в 1996 г. была принята «Концепция перехода Российской Федерации к устойчивому развитию» ${ }^{7}$. В современных национальных документах целям устойчивого развития, заявленным ООН, уделено особое внимание: в положениях Указа Президента России «О национальных целях развития Российской Федерации на период до 2030 года» ${ }^{8}$, а также в стратегии развития малого и среднего предпринимательства в России на период до 2030 г. и плане мероприятий («дорожной карте») по ее реализаций.

${ }^{4}$ Форрестер Дж. Мировая динамика. М.: АСТ, 2006. 384 с.; Медоуз Д. Х., Медоуз Д. Л., Рэндерс Й. Пределы роста : докл. по проекту Римского клуба «Сложное положение человечества». 2-е изд. М.: Изд-во МГУ, 1991. 207 с.

${ }^{5}$ Преобразование нашего мира: Повестка дня в области устойчивого развития на период до 2030 года. Резолюция, принятая Генеральной Ассамблеей ООН 25 сентября 2015 года [Электронный ресурc]. URL: https://unctad.org/system/files/official-document/ares70d1_ru.pdf (дата обращения: 11.12.2020).

${ }^{6}$ Зенченко С. А., Горбачев Н. Н. Экологический менеджмент в ЕС. Минск: Медисонт, 2018. 324 с.

${ }^{7}$ О Концепции перехода Российской Федерации к устойчивому развитию: Указ Президента Российской Федерации от 01.04.1996 № 440 [Электронный pecypc]. URL: http://www.consultant. $\mathrm{ru} /$ cons/cgi/online.cgi? req=doc\&base=EXP\&n=233558\#08987742907099916 （дата обращения: 17.04.2020).

${ }^{8}$ О национальных целях развития Российской Федерации на период до 2030 года: Указ Президента Российской Федерации от 21.07.2020 № 474 [Электронный ресурc]. URL: http:// publication.pravo.gov.ru/Document/View/0001202007210012 (дата обращения: 25.01.2021).

${ }^{9}$ О Стратегии развития малого и среднего предпринимательства в Российской Федерации на период до 2030 г. и плане мероприятий («дорожной карте») по ее реализации: Распоряжение Правительства Российской Федерации от 02.06.2016 № 1083-p [Электронный ресурс]. URL: https://www.garant.ru/products/ipo/prime/doc/71318202/ (дата обращения: 17.04.2020). 
Несмотря на такую высокую политическую и экономическую значимость и полную осознанность необходимости удовлетворения требований устойчивого развития мирового сообщества, единое мнение относительно содержания данного понятия в научной литературе еще не сложилось. В современных исследованиях ведутся активные дискуссии и представлено множество трактовок данного понятия.

П. К. Виртанен, Л. Сирагуса, Х. Гутторм отмечают, что в подходах к устойчивому развитию территории особое внимание уделяется отношениям, языку, традициям, а качество жизни измеряется и корректируется с учетом устойчивого развития человеческого сообщества [7]. А. Н. Багровникова устойчивое развитие связывает с «сохранением ресурсной базы, обеспечивающей удовлетворение потребностей нынешнего поколения, без ущерба будущему поколению, экономическому и социальному равновесию» [8, с. 21]. По мнению И. В. Шевченко и К. О. Литвинского, устойчивое развитие - это управляемый процесс, направленный на коэволюционное решение экономических, социальных и экологических проблем, а также существование в обществе социально- и экологически-ответственного бизнеса [9]. Т. Лахти, Й. Винсент и В. Парида под устойчивым развитием понимают процесс перехода на построение лучшего мира и более устойчивой окружающей среды [10].

Представленные определения устойчивого развития отражают экономическую, экологическую и социальную составляющие общества. Обеспечить устойчивое развитие общества в целом, региона, отрасли возможно лишь тогда, когда организации, независимо от их сферы деятельности и размера, будут устойчивыми.

Исследование трактовок понятия «устойчивое развитие предприятия», представленных в работах А. Л. Коваль [11], А. Г. Погорянской [12], М. М. Басова [13], П. П. Табурчак [14], О. В. Прокопенко ${ }^{10}$, А. М. Шилова [15], Э. Лаурин [16] и др., позволяет выделить некоторые общие черты авторских подходов к его определению. Одни ученые учитывают несколько аспектов деятельности предприятия - экологический, экономический и социальный $[10 ; 15]$, другие, кроме перечисленных, выделяют также производственную и технологическую составляющие ${ }^{11}$ [16]. Устойчивое развитие предприятия рассматривается большинством авторов как объект воздействия разнообразных и многочисленных внешних и внутренних факторов, которые предприятие должно учитывать и в отношении которых оно должно достигать устойчивости $[11 ; 12 ; 14]$.

Подавляющее число авторов устойчивое развитие предприятия трактует исключительно с экономической или финансовой точек зрения, не принимая

${ }^{10}$ Устойчивое развитие предприятия, региона, общества: инновационные подходы к обеспечению: моногр. / О. В. Прокопенко, И. А. Александров, Н. Н. Андреева, О. Ф. Яременко. Польша: Drukarnia i Studio Graficzne Omnidium, 2014. 474 c.

${ }^{11}$ Там же. 
во внимание другие аспекты его деятельности. Практически все из рассмотренных авторских трактовок не отражают одну из основополагающих особенностей концепции устойчивого развития, заключающуюся в том, что оно должно обеспечивать удовлетворение потребностей как нынешних, так и будущих поколений. Исходя из этого, устойчивое развитие организации следует трактовать как процесс целенаправленного социального и экономического развития предприятия, обеспечивающий сохранение и/или улучшение экологических характеристик производственной деятельности для удовлетворения текущих и будущих потребностей населения, учитывающий риски предприятия и влияние как внешних, так и внутренних факторов.

Устойчивое развитие должно рассматриваться в неразрывной связи с приоритетами будущих поколений на основе качественно нового типа развития и социально-экономического роста. Это отражает многогранность данного понятия и его комплексный характер, а также подчеркивает стратегическую направленность принятия управленческих решений в области устойчивого развития предприятия. В связи с этим необходимо рассмотреть опыт стран Европейского союза в области стратегического управления устойчивым развитием бизнеса. Следует отметить, что 25 миллионов малых и средних предприятий (МСП) в Европе являются основой экономики Европейского союза. В них занято около 100 миллионов человек, они составляют более половины ВВП Европы и играют ключевую роль в создании добавленной стоимости в каждом секторе экономики. МСП предлагают инновационные решения таких проблем, как изменение климата, эффективность использования ресурсов и социальная сплоченность. Они обеспечивают распространение этих инноваций по всем регионам Европы и играют центральную роль в двойном переходе Европейского союза к устойчивой и цифровой экономике. МСП необходимы также для повышения конкурентоспособности и процветания Европы, экономического и технологического суверенитета и устойчивости к внешним потрясениям.

Разработанная Европейским союзом «Стратегия МСП для устойчивой и цифровой Европы» является ключевой составляющей промышленной стратегии Европейского союза и базируется на реализации трех основных принципов:

- создании потенциала и поддержке перехода к устойчивому развитию и цифровизации;

- снижении регуляторной нагрузки и улучшении доступа на рынки;

- улучшении доступа к финансированию ${ }^{12}$.

В стратегии подробно рассмотрены необходимые условия реализации данных принципов независимо от сферы деятельности МПС.

${ }^{12}$ An SME Strategy for a Sustainable and Digital Europe. Communication from the Commission to the European Parliament, the Council, the European Economic and Social Committee and the Committee of the Regions. Brussels, 10.3.2020. COM (2020) 103 final. 18 p. 
В России наиболее успешные современные предприятия также начинают разрабатывать и реализовывать стратегии устойчивого развития. По мнению А. А. Гордиенко, К. В. Грохотовой и И. Б. Королевой, «стратегия устойчивого развития предприятия - это процесс непрерывных изменений на основе научно-технического прогресса, внедрения инноваций, совершенствования персонала с целью достижения стратегических целей» [17, с. 227].

В соответствии с этим, предприятие, встающее на путь устойчивого развития, должно в качестве ключевых приоритетов при принятии значимых для его будущего состояния управленческих решений учитывать принципы концепции устойчивого развития и руководствоваться ими.

Материалы и методы. На примере компании АО «Лидер-Компаунд» осуществлен анализ составляющих ее устойчивости. Материалами для исследования послужили отчетность организации за последние 8 лет ее работы (2012-2019 гг.), а также результаты проведенного анкетирования руководящего состава (20\% от общей численности персонала).

Были исследованы следующие составляющие предприятия:

- социальная - анализировался фонд оплаты труда АО «Лидер-Компаунд» в динамике, уровень заработной платы данного предприятия сопоставлялся со среднероссийским уровнем;

- экологическая - изучалась на основе принятой в компании Политики в области экологии;

- информационная - оценивалась степень реализации принципов устойчивого развития организации через сайт компании, который предоставляет информацию для всех заинтересованных сторон;

- финансово-экономическая - проводилась оценка рентабельности, платежеспособности и удельной себестоимости, что позволило определить эффективность управленческой деятельности.

Проведенное исследование позволило дать итоговую оценку соответствия АО «Лидер-Компаунд» особенностям стратегического управления устойчивым развитием малыми и средними предприятиями. С помощью SWOTанализа выявлены сильные и слабые стороны, а также угрозы и возможности предприятия. Все вышеизложенное позволило разработать этапы формирования стратегического управления устойчивым развитием предприятий малого бизнеса.

Результаты исследования. Особенности стратегического управления малыми и средними предприятиями анализировались во многих научных работах [18-21], в том числе и в наших более ранних публикациях ${ }^{13}$. В процессе исследования мы систематизировали полученные результаты и представили их в таблице 1.

${ }^{13}$ Гуськова Н. Д., Никитина Д. В. Особенности стратегического управления на предприятиях малого и среднего бизнеса // Сборник статей Всероссийской научно-технической конференции «Управление качеством в образовании и промышленности». Севастополь, 2020. С. 131-136. URL: https://lib.sevsu.ru/xmlui/handle/123456789/9292 (дата обращения: 07.12.2020). 
Т а б л и ц а 1. Систематизация особенностей стратегического управления малыми и средними предприятиями

$\mathrm{T} \mathrm{a} \mathrm{b} 1 \mathrm{e} 1$. Systematization of the features of strategic management of small and medium-sized enterprises

\begin{tabular}{c|c}
\hline $\begin{array}{c}\text { Ocoбенность } / \\
\text { Feature }\end{array}$ & Характеристика / Description \\
\hline 1 & 2 \\
\hline
\end{tabular}

Высокая чувстви- Тесное взаимодействие с ограниченным количеством поставтельность к измене- щиков и потребителей позволяет предприятиям своевременно ниям внешней сре- реагировать на смену хозяйственной конъюнктуры и другие ды / High sensitivity изменения внешней среды / Close interaction with a limited numto changes in the ex- ber of suppliers and consumers enables enterprises to respond to ternal environment changes in the economic conditions and the external environment in a timely manner

Высокая гибкость / На основе глубокой специализации и кооперации создаются High flexibility условия для быстрого реагирования на запросы потребителей и осуществление соответствующих изменений / Based on the increased specialization and cooperation, conditions are created for rapid response to consumer demands and for introduction of appropriate changes

Повышенная вос- Малый бизнес в силу своего небольшого размера, слабой форп р и и м ч и в о с т ь мализации и большей адаптивности быстрее реагирует и воск инновациям / In- принимает инновации / Small businesses, due to their small size, creased susceptibili- weak formalization and greater adaptability, are quicker to react and ty to innovation

Высокие риски / High risks accept innovations

Инновации влекут за собой высокие риски, поэтому возникает необходимость контроля за изменениями во внешней среде с целью сохранения рыночной ниши, а также текущего и будущего дохода / Innovations entail high risks, so there is a need to monitor changes in the environment in order to secure the niche in the market, as well as the current and future income

Высокая конкурен- Высокая конкуренция требует от предприятия высокой предция / Intense competition

Краткосрочность принимательской активности / Intense competition requires intense entrepreneurial activity of the enterprise

Short-termism

Малый объем документации / Small amount of documentation

Упрощенная аналитика / Simplified analytics

Планирование на предприятиях малого бизнеса как правило осуществляется на месяц, квартал или год / Small business planning is usually done for a month, quarter, or year

Небольшой объем документации приводит к информационной ограниченности при принятии управленческих решений / Small amount of documentation leads to informational limitations when making managerial decisions

Анализ внешней и внутренней среды предприятия проводится по упрощенному алгоритму в связи с недостаточностью информационного и кадрового обеспечения / Analysis of the external and internal environments of the enterprise is carried out according to a simplified algorithm due to the lack of information and staffing 
Оперативное принятие решений / Quick decision-making
Малая иерархичность организационной структуры позволяет принимать быстрые управленческие решения / Small hierarchy of the organizational structure makes it possible to make quick managerial decisions

В ов лече нн о с ть персонала / Staff involvement
Слабая формализация позволяет вовлекать весь персонал предприятия в принятие и реализацию решений / Weak formalization makes it possible for the entire staff of the enterprise to be involved in making and implementing decisions

Принятие стратегических решений в малом и среднем предпринимательстве во многом определяется особенностями той отрасли, в которой они осуществляют свою деятельность. Акционерное общество «ЛидерКомпаунд» (АО «Лидер-Компаунд»), образованное в сентябре 2010 г., осуществляет свою деятельность в высокотехнологичной отрасли и планомерно развивается в направлении освоения самых современных кабельных технологий.

Устойчивое развитие предприятия во многом определяется профессиональными и личностными компетенциями персонала, его удовлетворенностью условиями и оплатой труда. Результаты анкетирования персонала предприятия (57 \% от общей численности сотрудников) показали высокую удовлетворенность условиями труда (4,6 балла по 5-балльной шкале). В 2019 г. произошло некоторое снижение размера заработной платы, что отразилось на снижении удовлетворенности персонала уровнем оплаты труда. В то же время следует отметить, что средняя заработная плата на предприятии в 1,5 раза выше, чем в целом по региону.

Стратегические аспекты экологической составляющей АО «Лидер-Компаунд» закреплены в принятой в компании Политике в области экологии. В ней организация принимает на себя обязательства по достижению высоких результатов в области экологии, снижению негативных воздействий своей деятельности на окружающую среду и предотвращению ее загрязнения. Для реализации этой цели в политике обозначено стремление к постоянной идентификации, оценке и управлению элементами своей деятельности, которые оказывают воздействие на окружающую среду.

Оценка состояния экономической составляющей проводилась по обеспеченности предприятия собственными средствами, рентабельности, финансовой устойчивости, платежеспособности и удельной себестоимости. Оно характеризует устойчивое положение АО «Лидер-Компаунд» как в динамике, так и по среднеотраслевым значениям показателей (табл. 2).

Используя данные таблицы 2, рассчитаем коэффициент эффективности управленческой деятельности АО «Лидер-Компаунд» (рис. 1). 
Т а б л и ц а 2. Показатели, необходимые для расчета коэффициента эффективности управленческой деятельности АО «Лидер-Компаунд» в 2012-2019 гг.

$\mathrm{T}$ a $\mathrm{b} 1 \mathrm{e} 2$. Indicators required for calculating the efficiency factor of management activities of JSC Leader-Compound in 2012-2019

\begin{tabular}{|c|c|c|c|c|c|c|c|c|}
\hline Показатель / Indicator & 2012 & 2013 & 2014 & 2015 & 2016 & 2017 & 2018 & 2019 \\
\hline $\begin{array}{l}\text { Управленческие pac- } \\
\text { ходы, тыс. руб. / Ad- } \\
\text { ministrative expenses, } \\
\text { thousand rubles }\end{array}$ & 6097 & 16171 & 22380 & 24446 & 32610 & 32957 & 32999 & 38976 \\
\hline $\begin{array}{l}\text { Темп прироста управ- } \\
\text { ленческих расходов / } \\
\text { Growth rate of admini- } \\
\text { strative expenses }\end{array}$ & - & 165,23 & 38,40 & 9,23 & 33,40 & 1,06 & 0,13 & 18,11 \\
\hline $\begin{array}{l}\text { Чистая прибыль (убы- } \\
\text { ток), тыс. руб. / Net } \\
\text { profit (dead loss), thou- } \\
\text { sand rubles }\end{array}$ & -40724 & -8986 & -3388 & 5921 & 16238 & 15008 & 11721 & 32119 \\
\hline $\begin{array}{l}\text { Темп прироста чистой } \\
\text { прибыли / Growth rate } \\
\text { of net profit }\end{array}$ & - & - & - & - & 174,24 & $-7,57$ & $-21,90$ & 174,03 \\
\hline
\end{tabular}

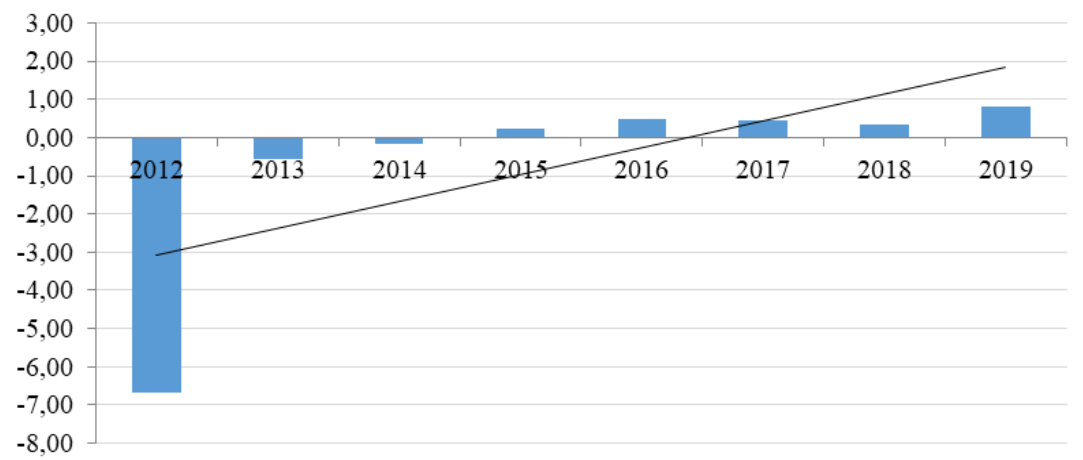

Р и с. 1. Динамика коэффициента эффективности управленческой деятельности АО «Лидер-Компаунд» в 2012-2019 гг.

F i g. 1. Dynamics of the efficiency factor of management activities of JSC Leader-Compound in 2012-2019

Как видим, коэффициент эффективности управления в АО «Лидер-Компаунд» в первые годы его существования имел отрицательные значения. Компания на этапе освоения нового производства с высокой кредитной нагрузкой имела отрицательный финансовый результат, управленческие расходы составляли достаточно скромное значение, многие направления менеджмента только 
начинали развиваться. В последующие годы происходило постепенное и ожидаемое улучшение финансового состояния компании, одновременно с этим имел место ощутимый рост расходов на осуществление управленческой деятельности. Линия тренда на рисунке 1 демонстрирует уверенную положительную динамику, что сохраняется вплоть до текущего времени.

Результатом комплексного анализа всех составляющих устойчивого развития компании стало проведение итоговой оценки соответствия АО «ЛидерКомпаунд» особенностям стратегического управления устойчивым развитием малыми и средними предприятиями на основе таблицы 1. На рисунке 2 представлены результаты экспертной оценки данных особенностей по 5-балльной шкале, где оценка «5» характеризует полное соответствие критерию, а оценка «0»- полное несоответствие. В качестве экспертов выступали руководители и специалисты структурных подразделений данного предприятия (20 \% от общей численности персонала - 15 чел.).

Высокая чувствительность

к изменениям внешней

среды / High sensitivity to

changes in the external

environment

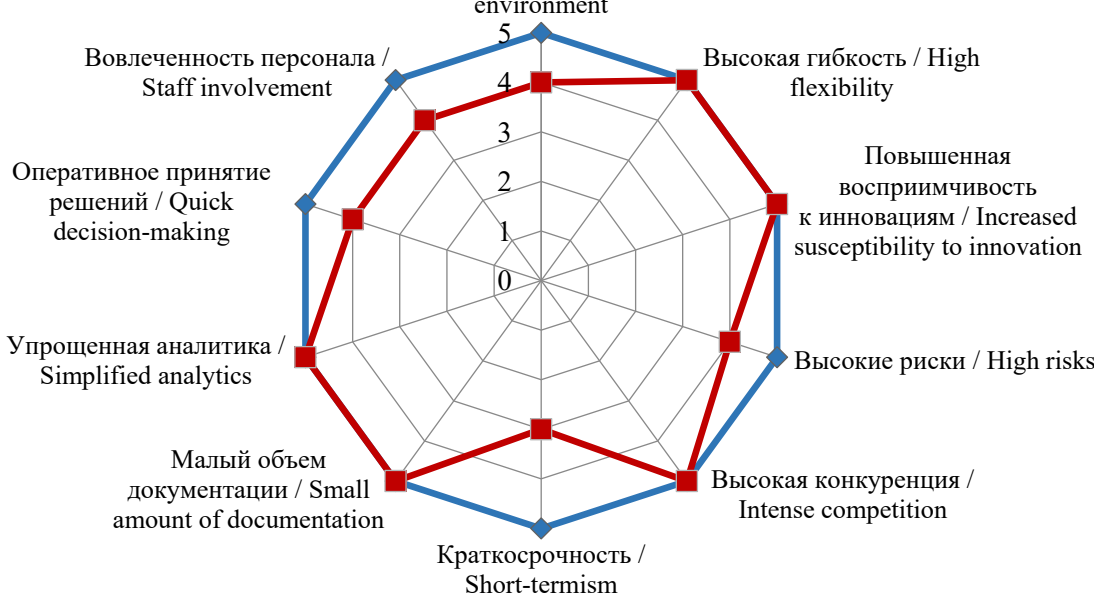

$\sim$ Соответствие субъекту малого предпринимательства / Features of strategic management of a small business enterprise

-ш- АО «Лидер-Компаунд» / JSC Leader-Compound

Р и с. 2. Оценка соответствия АО «Лидер-Компаунд» особенностям стратегического управления малыми и средними предприятиями, баллы

F i g. 2. Assessment of compliance of JSC Leader-Compound with the features of strategic management of small and medium-sized enterprises, points 
Представленная на рисунке 2 диаграмма-паутина позволяет сделать следующие выводы:

- компания в силу сложности и уникальности применяемой технологии в российских условиях не имеет высокой чувствительности к изменениям внешней среды за исключением такого фактора, как стоимость сырья и материалов;

- риски в деятельности компании достаточно многочисленны, но не настолько критичны, как это свойственно малым предприятиям;

- оперативность принятия решений в компании не соответствует скорости, сравнимой с субъектами малого и среднего предпринимательства, в силу того, что компания является акционерным обществом, следовательно, большинство принципиальных решений, в первую очередь стратегической направленности, принимается советом директоров и на акционерном собрании;

- вовлеченность персонала в процесс принятия решений, в отличие от традиционной для субъектов малого и среднего предпринимательства, недостаточно высокая.

В связи с этим у АО «Лидер-Компаунд» имеется ряд особенностей, позитивно отличающих его от низкого уровня развития стратегического управления в компаниях малого и среднего бизнеса. Этому во многом способствуют отраслевые особенности его функционирования, а также накопленный положительный опыт развития кабельного производства в Республике Мордовия.

Результаты проведенного анализа стратегического управления устойчивым развитием АО «Лидер-Компаунд» позволяют предложить процесс разработки и реализации стратегии его устойчивого развития по следующим этапам.

Этап 1. Формирование концепции устойчивого развития на основе анализа социильных, экологических и экономических аспектов деятельности компании. На этом этапе предусматривается генерация концептуальных идей и формирование единого подхода в области устойчивого развития компании.

Этап 2. Прогнозирование ключевых аспектов устойчивого развития региона и отрасли на основе анализа факторов внешней и внутренней среды. Данное прогнозирование предлагается осуществлять с учетом экономических, экологических, управленческих и социальных факторов внутренней среды на основе их систематизации.

Этап 3. Оценка состояния факторов и степени их влияния на компанию. Данную оценку необходимо проводить с позиции определения степени их воздействия на устойчивое развитие компании. Для этого целесообразно разработать специальную интегральную оценку, учитывающую специфику деятельности компании (табл. 3). 


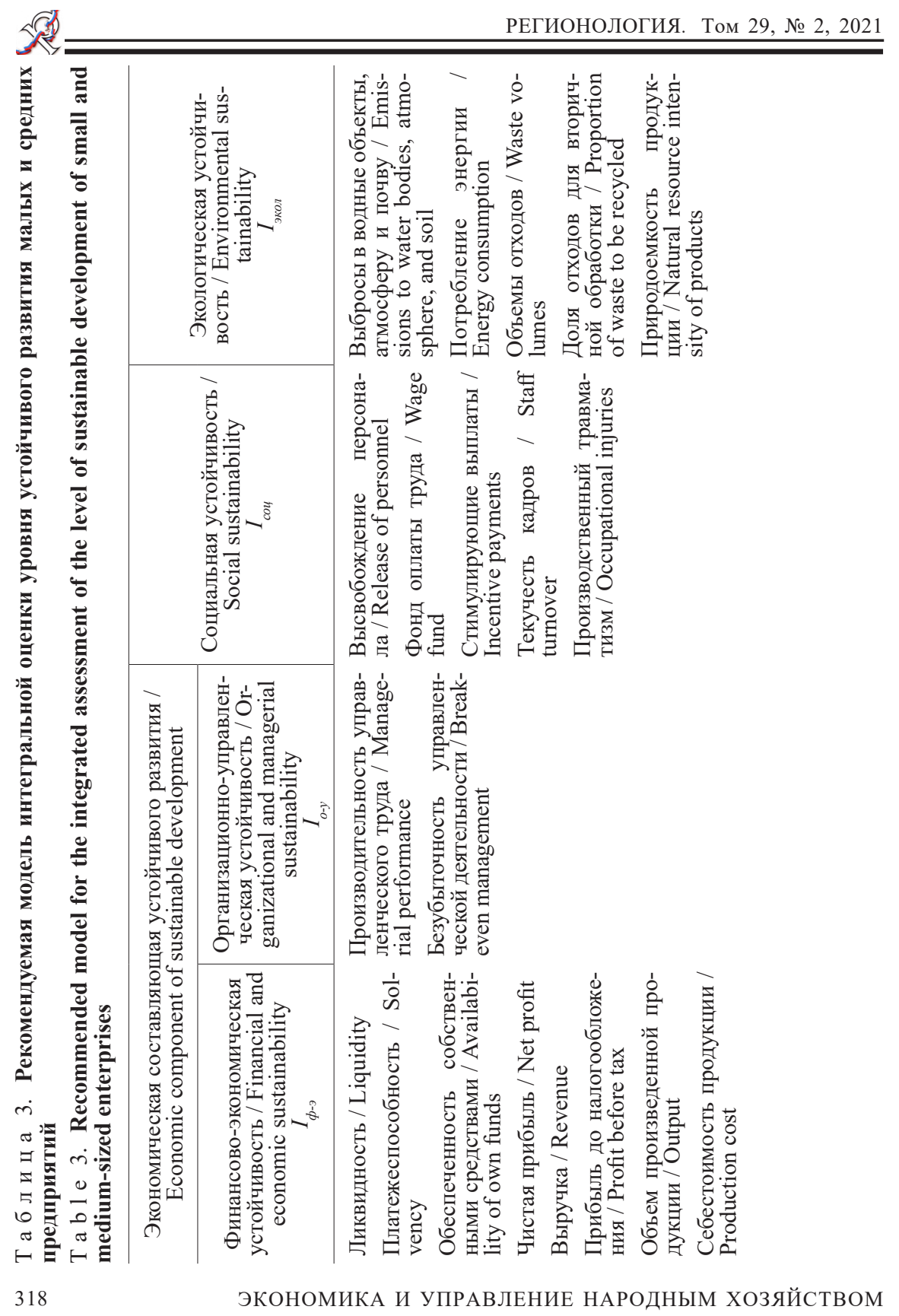


Предлагаемая модель может и должна быть адаптирована для оценки деятельности конкретного предприятия с позиции специфики, наличия и доступности соответствующей информации по отдельным показателям.

Для расчета обобщенного интегрального показателя уровня устойчивого развития предлагается использовать следующую математическую модель, учитывающую составляющие устойчивого развития предприятия:

$$
I_{\text {уР }}=I_{\phi-э} \cdot q_{1}+I_{о-y} \cdot q_{2}+I_{\text {соч }} \cdot q_{3}+I_{\text {экол }} \cdot q_{4},
$$

где $q_{1}, q_{2}, q_{3}$ и $q_{4}$ - весовые коэффициенты важности соответствующей составляющей устойчивого развития предприятия, которые обладают свойствами $0<q_{\mathrm{i}}<1$, их сумма не должна быть больше 1 .

Так как устойчивое развитие предприятия определяется балансом его составляющих, то весовые коэффициенты будут следующими: $q_{1}-0,27 ; q_{2}-$ 0,07 , а их сумма равна 0,$34 ; q_{3}$ и $q_{4}$ равны 0,33 .

Данная модель является универсальной и может быть использована в практической деятельности как малых, так и средних предприятий.

Этап 4. Идентификация рисков и возможностей. Идентификация рисков АО «Лидер-Компаунд» в настоящее время проводится ежегодно в рамках составления годового отчета. В отчете лишь обозначаются риски, но не дается какая-либо оценка относительно степени их влияния на компанию в стратегической перспективе. Кроме того, стратегическое управление требует определения потенциальных возможностей развития, которые можно рассматривать в контексте отраслевого и/или регионального развития. На наш взгляд, на этом этапе необходимо проведение SWOT-анализа компании. Опираясь на идентифицированные в годовом отчете АО «Лидер-Компаунд» риски, проведем SWOT-анализ по состоянию на 2020 г. и его результаты представим в форме таблицы (табл. 4).

Этап 5. Разработка мероприятий по снижению рисков и реализащии возможностей. На данном этапе требуется формирование программы внедрения принципов устойчивого развития в деятельности компании.

Этап 6. Формирование и размещение открытой отчетности в области устойчивого развития. Учитывая высокий уровень конкурентоспособности продукции предприятия наравне с ведущими зарубежными компаниями, для АО «Лидер-Компаунд» имеет определенную целесообразность формирование отчетности в области устойчивого развития по соответствующим международным стандартам (GRI, AA1000 и т. п.) и их размещение на зарубежных сайтах для привлечения новых стратегически важных клиентов.

Предложенный процесс разработки и реализации стратегии устойчивого развития позволит АО «Лидер-Компаунд» не только сформировать обоснованную по составляющим устойчивого развития стратегию, но и обеспечит возможность ее успешной реализации. 
Т а б л и ц а 4. SWOT-анализ АО «Лидер-Компаунд»

$\mathrm{T}$ a $\mathrm{b} 1$ e 4 . SWOT analysis of JSC Leader-Compound

\begin{tabular}{|c|c|}
\hline Возможности / Opportunities & Угрозы / Threats \\
\hline $\begin{array}{l}\text { Появление новых потребителей / Emergence } \\
\text { of new consumers }\end{array}$ & $\begin{array}{l}\text { Изменение таможенного законодатель- } \\
\text { ства / Changes in customs legislation }\end{array}$ \\
\hline $\begin{array}{l}\text { Увеличение количества потребителей на } \\
\text { внутреннем рынке / Increase in the number of } \\
\text { consumers in the domestic market }\end{array}$ & $\begin{array}{l}\text { Нестабильная экономическая ситуация } \\
\text { в мире / Unstable economic situation in } \\
\text { the world }\end{array}$ \\
\hline $\begin{array}{l}\text { Повышение качества продукции / Product } \\
\text { quality improvement }\end{array}$ & $\begin{array}{l}\text { Демпинг цен, увеличение количества } \\
\text { производителей и поставщиков на рын- }\end{array}$ \\
\hline $\begin{array}{l}\text { Расширение ассортимента продукции } \\
\text { и списка предоставляемых услуг / Ехрап- }\end{array}$ & $\begin{array}{l}\text { ке / Price dumping, increase in the number } \\
\text { of manufacturers and suppliers in the market }\end{array}$ \\
\hline $\begin{array}{l}\text { sion of the range of products and services pro- } \\
\text { vided }\end{array}$ & $\begin{array}{l}\text { Потеря потребителей вследствие по- } \\
\text { ставки некачественной продукции / }\end{array}$ \\
\hline $\begin{array}{l}\text { Повышение объемов производства / In- } \\
\text { crease in production volumes }\end{array}$ & $\begin{array}{l}\text { Loss of consumers due to the supply of } \\
\text { low-quality products }\end{array}$ \\
\hline $\begin{array}{l}\text { Диверсификация производства / Diversifica- } \\
\text { tion of production }\end{array}$ & $\begin{array}{l}\text { Невозврат возрастающей дебиторской } \\
\text { задолженности / Failure to repay increa- } \\
\text { sing receivables }\end{array}$ \\
\hline $\begin{array}{l}\text { Отсутствие российских конкурентов / Ab- } \\
\text { sence of Russian competitors }\end{array}$ & $\begin{array}{l}\text { Высокая зависимость от зарубежных } \\
\text { поставщиков сырья / Heavy dependence } \\
\text { on foreign suppliers of raw materials }\end{array}$ \\
\hline
\end{tabular}

\begin{tabular}{l} 
Сильные стороны / \\
Strengths \\
\hline Инновационность продук- \\
та / Product innovativeness \\
Высокое качество выпус- \\
каемой продукции / High \\
quality of products \\
Хорошая репутация / Good \\
reputation \\
Высокий кадровый потен- \\
циал / Нigh human resources \\
сарасіty
\end{tabular}

Возможность снижения себестоимости продукта / Possibility to reduce the cost of the product

Возможность снижения цены на продукт / Possibility to reduce the price of the product Реализация мер внутреннего контроля / Implementation of internal control measures

Внедрение комплекса мер для защиты информации / Introduction of a set of measures to protect information

\section{Силы и возможности / Strengths and Opportunities}

Повышение репутации и конкурентоспособности компании благодаря повышению качества и ассортимента продукции на традиционном рынке / Enhancing the reputation and competitiveness of the company by improving the quality and range of products in the traditional market

Выход на зарубежный рынок при снижении себестоимости продукции / Entering the foreign market while reducing the cost of production

Освоение новых рынков на основе стратегии диверсификации / Entering new markets following the strategy of diversification

Повышение открытости информации о компании в области устойчивого развития / Increasing the transparency of information about the company regarding sustainable development
Силы и угрозы /

Strengths and Threats

Поддержание высокого качества при одновременном снижении себестоимости на основе бережливого подхода позволит усилить рыночные позиции / Maintaining high quality while reducing costs through lean production will make it possible to strengthen the market position

Внедрение принципов устойчивого развития в стратегическое управление компанией создаст условия для своевременного предотвращения потенциальных угроз / Introduction of sustainable development principles into the strategic management of the company will create conditions for timely prevention of potential threats 
Окончание табл. 4 / End of table 4

\begin{tabular}{|c|c|c|}
\hline ны / Weak- & & \\
\hline $\begin{array}{l}\text { Несовершенство системы } \\
\text { внутреннего контроля / Im- } \\
\text { perfection of the internal con- } \\
\text { trol system }\end{array}$ & \multirow{5}{*}{\multicolumn{2}{|c|}{ 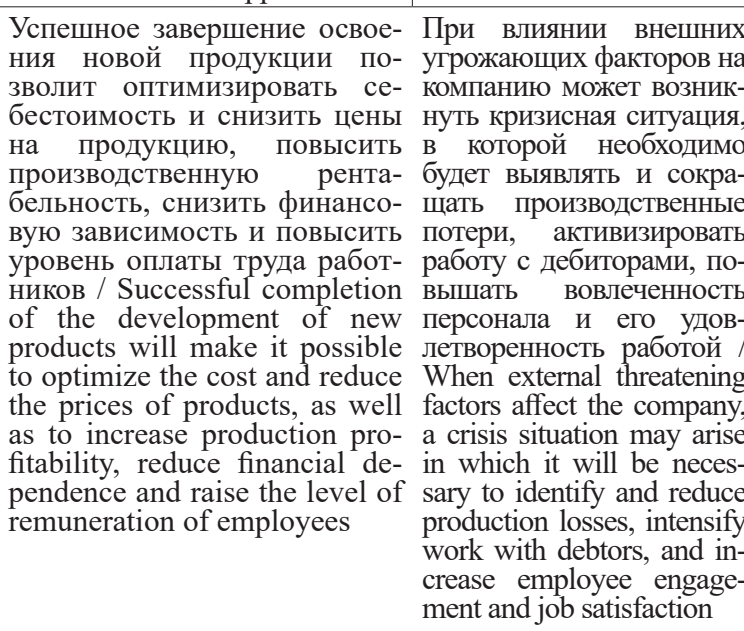 }} \\
\hline $\begin{array}{l}\text { Ошибки функционирования } \\
\text { компьютерных систем / Er- } \\
\text { rors in the functioning of com- } \\
\text { puter systems }\end{array}$ & & \\
\hline $\begin{array}{l}\text { беспеченность соб- } \\
\text { и средствами / Li- } \\
\text { lability of own funds }\end{array}$ & & \\
\hline $\begin{array}{lr}\text { Низкая производст } \\
\text { рентабельность } \\
\text { постоянного }\end{array}$ & & \\
\hline $\begin{array}{l}\text { Снижение уро } \\
\text { труда работникс }\end{array}$ & & \\
\hline
\end{tabular}
in the level of remuneration of employees

Обсуждение и заключение. Таким образом, авторами проведен анализ нормативно-правовых документов, регламентирующих деятельность малого и среднего бизнеса как в Российской Федерации, так и в странах Европейского союза. Дан критический обзор научных разработок отечественных и зарубежных авторов в области устойчивого развития в целом, и в сфере малого и среднего бизнеса в частности.

В процессе исследования установлены особенности стратегического управления малыми и средними предприятиями: высокая чувствительность к изменениям внешней среды, повышенная восприимчивость к инновациям, высокие риски и конкуренция, малый объем документации, вовлеченность персонала и др. Была дана итоговая оценка соответствия исследуемого предприятия особенностям стратегического управления устойчивым развитием малыми и средними предприятиями. Выявлены его сильные и слабые стороны, а также угрозы и возможности с помощью инструмента стратегического управления (SWOT-анализа). Предложена модель интегральной оценки уровня устойчивого развития малых и средних предприятий и процесс разработки и реализации стратегии устойчивого развития предприятий малого бизнеса, включающий следующие этапы: формирование концепции устойчивого развития; прогнозирование ключевых аспектов устойчивого развития региона и отрасли; оценка состояния факторов и степени их влияния на компанию; 
идентификация рисков и возможностей; разработка мероприятий по снижению рисков и реализации возможностей; формирование и размещение открытой отчетности в области устойчивого развития.

Дальнейшие исследования в данной научной сфере будут затрагивать проблемы, возникающие в деятельности предприятий малого и среднего бизнеса под воздействием быстро меняющихся факторов внешней среды, а именно: роста инфляции, пандемии, высокой миграции населения и сложности, связанной с поиском молодых квалифицированных специалистов.

Полученные в процессе исследования результаты могут быть использованы в практике стратегического управления устойчивым развитием предприятий малого и среднего бизнеса в любой сфере деятельности.

\section{СПИСОК ИСПОЛЬЗОВАННЫХ ИСТОЧНИКОВ}

1. Competitiveness, Sustainable Development and Import Substitution Problems in the Russian Federation / T. A. Salimova, N. D. Gouskova, L. Fedoskina, I. A. Gorin // Journal of Applied Economic Sciences. - 2017. - T. 12, no. 4 (50). - Pp. 1148-1161. - URL: http://cesmaa.org/Docs/JAES\%20Summer\%20XII\%204(50)2017.pdf (дата обращения: 08.06.2020).

2. Waste Management in Green and Smart Cities: a Case Study of Russia / Z. Mingaleva, N. Vukovic, I. Volkova, T. Salimova. - DOI 10.3390/su12010094 // Sustainability. 2020. - Vol. 12, no. 1. - Pp. 1-17. - URL: https://www.mdpi.com/2071-1050/12/1/94 (дата обращения: 07.12.2020).

3. Towards Sustainable Development Via Enhancing Viability of Small Businesses Through Lending: A Case Study / A. Seisenbayeva, N. A. Gumar, M. Imramziyeva [et al.] // Journal of Security and Sustainability Issues. - 2020. - Vol. 9, issue 3. - Pp. 943-950. URL: https://journals.lka.lt/journal/jssi/article/677/info (дата обращения: 05.05.2020).

4. Towards a Methodology of Sustainable Competitiveness of Organization / T. A. Salimova, L. I. Biryukova, A. T. Shilkina, E. V. Khakhaleva // International Journal of Civil Engineering and Technology. - 2018. - Vol. 9, issue 11. - Pp. 161-172. - URL: https://www. researchgate.net/publication/329732083_Towards_a_methodology_of_sustainable_competitiveness_of_organization (дата обращения: 22.01.2020).

5. Cantele, $\overline{\mathrm{S}}$. Is Sustainability a Competitive Advantage for Small Businesses? An Empirical Analysis of Possible Mediators in the Sustainability-Financial Performance Relationship / S. Cantele, A. Zardini. - DOI 10.1016/j.jclepro.2018.02.016 // Journal of Cleaner Production. - 2018. - Vol. 182. - Pp. 166-176. - URL: https:/www.sciencedirect.com/ science/article/pii/S0959652618303202?via\%3Dihub (дата обращения: 08.06.2020).

6. Environment and Sustainable Development / edited by M. Kḷvinšs, W. Leal Filho, Jānis Zaḷoksnis. - Riga : Fcademic Press of University of Latvia, 2010. - 300 p. - URL: https://issuu.com/janisbrizga/docs/e-sd-druka (дата обращения: 08.06.2020).

7. Virtanen, P. K. Introduction: Toward More Inclusive Definitions of Sustainability Current Opinion in Environmental / P. K. Virtanen, L. Siragusa, H. Guttorm. - DOI 10.1016/j. cosust.2020.04.003 // Sustainability. - 2020. - Vol. 43. - Pp. 77-82. - URL: https://www. sciencedirect.com/science/article/pii/S1877343520300300 (дата обращения: 07.12.2020). 
8. Багровникова, А. Н. Вопросы моделирования экономической устойчивости развития предприятия / А. Н. Багровникова // Социально-экономическое управление: теория и практика. - 2019. - № 4 (39). - C. 5-9. - URL: https://istu.ru/storage/documents/ izdat/seu/2019-4/Багровникова.pdf (дата обращения: 13.05.2020). - Рез. англ.

9. Шевченко, И. В. Устойчивое развитие: мировой опыт и проблемы России / И. В. Шевченко // Региональная экономика: теория и практика. - 2007. - № 13. - С. 3-10. - URL: https://www.fin-izdat.ru/journal/region/detail.php?ID=7912 (дата обращения: 18.04.2020).

10. Lahti, T. A Definition and Theoretical Review of the Circular Economy, Value Creation, and Sustainable Business Models: Where are we now and Where Should Research Move in the Future? / T. Lahti, J. Wincent, V. Parida. - DOI 10.3390/su10082799 // Sustainability. - 2018. - Vol. 10, issue 8. - URL: https://www.mdpi.com/2071-1050/10/8/2799 (дата обращения: 19.04.2020).

11. Коваль, А. Л. Факторы устойчивого развития транспортных предприятий / А. Л. Коваль, А. А. Степнова, Н. А. Щербакова // Транспортное дело России. - 2018. № 6. - C. 246-248. - URL: http://www.morvesti.ru/izdaniya/tdr/archive/2018/06.php (дата обращения: 29.04.2020). - Рез. англ.

12. Погорянская, А. Г. Устойчивое развитие как результирующий фактор эффективной хозяйственной деятельности / А. Г. Погорянская, В. А. Крахина // Научнообразовательный потенциал молодежи в решении актуальных проблем XXI века. 2018. - № 10. - C. 78-81. - URL: https://www.elibrary.ru/item.asp?id=35021136 (дата обращения: 20.04.2020). - Рез. англ.

13. Басова, М. М. Роль стратегического баланса экономических, экологических и социальных аспектов устойчивого развития ПАО «ФСК ЕЭС» / М. М. Басова. DOI 10.17747/2311-7184-2018-1-16-20 // Стратегии бизнеса. - 2018. - № 1 (45). C. 16-20. - URL: https://www.strategybusiness.ru/jour/article/view/397 (дата обращения: 28.04.2020). - Рез. англ.

14. Табурчак, П. П. Механизм устойчивого развития предприятия с использованием его организационного потенциала / П. П. Табурчак, М. А. Микитась // Управление экономическими системами: электронный научный журнал. - 2012. № 4 (40). - URL: http://uecs.ru/index.php?option=com flexicontent\&view=items\& id=1311:2012-04-28-09-32-19 (дата обращения: 12.04.2020). - Рез. англ.

15. Шилова, А. М. Концептуализация понятия «устойчивое развитие промышленного предприятия» / А. М. Шилова // Master's Journal. - 2014. - № 2. - С. 287-296. URL: http://vestnik.pstu.ru/mj/archives/?id=\&folder_id=4322 (дата обращения: 12.09.2020). - Рез. англ.

16. Laureen, E. Global Governance and Sustainability Indicators: The Politics of Expert Knowledge / E. Laureen. - DOI 10.4337/9781783472352.00027 // Handbook of Critical Policy Studies. - 2016. - Pp. 341-357. - URL: https://www.elgaronline.com/view/edcoll/9781783472345/9781783472345.xml (дата обращения: 12.09.2020).

17. Гордиенко, А. А. Влияние стратегии устойчивого развития на деятельность нефтегазовых компаний / А. А. Гордиенко, К. В. Грохотова, И. Б. Королева // Global and Regional Research. - 2019. - T. 1, № 3. - C. 225-232. - URL: http://grr-bgu.ru/reader/ article.aspx?id=23201 (дата обращения: 18.06.2020). - Рез. англ.

18. Титов, В. С. Особенности стратегического управления малым предприятием / В. С. Титов, А. Хайдар, А. А. Кузнецов // Вестник Российского университета 
дружбы народов. Серия: Инженерные исследования. - 2009. - № 4. - С. 123-125. URL: http://journals.rudn.ru/engineering-researches/article/view/4831 (дата обращения: 10.09.2020).

19. Мильнер, Б. Малый бизнес: проблемы организации и управления / Б. Мильнер, Т. Орлова // Проблемы теории и практики управления. - 2013. - № 4. - С. 18-30. URL: https:/ptpmag.ru/malyj-biznes-problemy-organizacii-i-upravlenija/ (дата обращения: 18.09.2020).

20. Мосина, Е. А. Региональное малое предпринимательство: необходимые условия и перспективы развития / Е. А. Мосина. - DOI 10.17922/2071-3665-2016-15-1-17-23 // Социальная политика и социология. - 2016. - № 1 (114). - С. 17-23. - URL: https://rgsu. net/netcat_files/multifile/5219/SP_1_2016_V_PEChAT_pdf (дата обращения: 28.04.2020).

21. Фадеева, Е. А. Особенности стратегического управления малыми предприятиями в современных условиях / Е. А. Фадеева, А. А. Маргарян // Бизнес. Образование. Право. 2015. - № 1 (30). - C. 56-59. - URL: http://vestnik.volbi.ru/webarchive/130/yekonomicheskienauki/osobennosti-strategicheskogo-upravlenija.html (дата обращения: 20.05.2020).

Поступила 24.12.2020; одобрена после рецензирования 29.01.2021; принята к публикации 09.02.2021.

Об авторах:

Гуськова Надежда Дмитриевна, профессор кафедры менеджмента ФГБОУ ВО «МГУ им. Н. П. Огарёва» (430005, Российская Федерация, г. Саранск, ул. Большевистская, д. 68/1), доктор экономических наук, ORCID: https://orcid.org/0000-0002-24739657, Scopus ID: 56646366400,guskov4nd@yandex.ru

Ерастова Александра Валерьевна, доцент кафедры менеджмента ФГБОУ ВО «МГУ им. Н. П. Огарёва» (430005, Российская Федерация, г. Саранск, ул. Большевистская, д. 68/1), кандидат экономических наук, ORCID: https://orcid.org/0000-0003-29207112, Scopus ID: 57191528367, erastova.74@inbox.ru

Никитина Дарья Викторовна, менеджер отдела контекстной рекламы департамента перформанс рекламы агентства «СберМаркетинг» (117997, Российская Федерация, г. Москва, ул. Вавилова, д. 19), ORCID: https://orcid.org/0000-0002-4214-1210, nidaria96@mail.ru

Заявленный вклад авторов:

Н. Д. Гуськова - научное руководство; литературный обзор по исследуемой проблематике; разработка модели интегральной оценки уровня устойчивого развития малых и средних предприятий; обобщение результатов исследования.

А. В. Ерастова - структурное построение статьи; обоснование актуальности исследуемой проблемы; подготовка первоначального варианта текста; проведение критического анализа материалов.

Д. В. Никитина - сбор и обработка аналитической информации; разработка проекта программы внедрения принципов устойчивого развития в стратегическое управление АО «Лидер-Компаунд».

Авторы прочитали и одобрили окончательный вариант рукописи. 


\section{REFERENCES}

1. Salimova T.A., Gouskova N.D., Fedoskina L., Gorin I.A. Competitiveness, Sustainable Development and Import Substitution Problems in the Russian Federation. Journal of Applied Economic Sciences. 2017; 12(4):1148-1161. Available at: http://cesmaa. org/Docs/JAES\%20Summer\%20XII\%204(50)2017.pdf (accessed 08.06.2020). (In Eng.)

2. Mingaleva Z., Vukovic N., Volkova I., Salimova T. Waste Management in Green and Smart Cities: A Case Study of Russia. Sustainability. 2020; 12(1):1-17. (In Eng.) DOI: https://doi.org/10.3390/su12010094

3. Seisenbayeva A., Gumar N.A., Imramziyeva M., Lapbayeva S., Shmanova N. Towards Sustainable Development Via Enhancing Viability of Small Businesses Through Lending: a Case Study. Journal of Security and Sustainability Issues. 2020; 9(3):943-950. Available at: https://journals.lka.lt/journal/jssi/article/677/info (accessed 05.05.2020). (In Eng.)

4. Salimova T.A., Biryukova L.I., Shilkina A.T., Khakhaleva E.V. Towards a Methodology of Sustainable Competitiveness of Organization. International Journal of Civil Engineering and Technology. 2018; 9(11):161-172. Available at: https://www.researchgate.net/ publication/329732083_Towards_a_methodology_of_sustainable_competitiveness_of organization (accessed $2 \overline{2} .01 .2020)$.

5. Cantele S., Zardini A. Is Sustainability a Competitive Advantage for Small Businesses? An Empirical Analysis of Possible Mediators in the Sustainability-Financial Performance Relationship. Journal of Cleaner Production. 2018; 182:166-176. (In Eng.) DOI: https://doi. org/10.1016/j.jclepro.2018.02.016

6. Environment and Sustainable Development / M. Kḷaviņš, W. Leal Filho, J. Zal̨oksnis (eds.). Riga: Academic Press of University of Latvia; 2010. Available at: https://issuu.com/ janisbrizga/docs/e-sd-druka (accessed 08.06.2020). (In Latvian)

7. Virtanen P.K., Siragusa L., Guttorm H. Introduction: Toward More Inclusive Definitions of Sustainability Current Opinion in Environmental. Sustainability. 2020; 43:77-82. (In Eng.) DOI: https://doi.org/10.1016/j.cosust.2020.04.003

8. Bagrovnikova A.N. Issues of Modelling Economic Sustainability of Enterprise Development. Sotsialno-ehkonomicheskoe upravlenie: teoriya i praktika $=$ Socio-Economic Management: Theory and Practice. 2019; (4):5-9. Available at: https:// istu.ru/storage/documents/izdat/seu/2019-4/Багровникова.pdf (accessed 13.05.2020). (In Russ., abstract in Eng.)

9. Shevchenko I.V. Sustainable Development: World Experience and Problems of Russia. Regionalnaya ehkonomika: teoriya i praktika = Regional Economics: Theory and Practice. 2007; (13):3-10. Available at: https://www.fin-izdat.ru/journal/region/detail.php?ID=7912 (accessed 18.04.2020). (In Russ.)

10. Lahti T., Wincent J., Parida V. A Definition and Theoretical Review of the Circular Economy, Value Creation, and Sustainable Business Models: Where are we now and Where Should Research Move in the Future? Sustainability. 2018; 10(8). (In Eng.) DOI: https://doi. org $/ 10.3390 /$ su10082799

11. Koval A.L., Stepnova A.A., Scherbakova N.A. Factors of Sustainable Development of Transport Enterprises. Transportnoe delo Rossii $=$ Transport Business of Russia. 2018; (6):246-248. Available at: http://www.morvesti.ru/izdaniya/tdr/archive/2018/06.php (accessed 29.04.2020). (In Russ., abstract in Eng.) 
12. Pogoryanskaya A.G., Krakhina V.A. Sustainable Development as the Resultant Factor of Efficient Economic Activity. Nauchno-obrazovatelnyj potentsial molodezhi v reshenii aktualnykh problem XXI veka $=$ Scientific and Educational Potential of the Youth in Solving Urgent Problems of the $21^{\text {st }}$ Century. 2018; (10):78-81. Available at: https://www.elibrary.ru/ item.asp?id=35021136 (accessed 20.04.2020). (In Russ., abstract in Eng.)

13. Basova M.M. The Role of the Strategic Balance of Economic, Environmental and Social Aspects of Sustainable Development of JSC "Grid Company". Strategii bizne$s a=$ Business Strategies. 2018; (1):16-20. (In Russ., abstract in Eng.) DOI: https://doi. org/10.17747/2311-7184-2018-1-16-20

14. Taburchak P.P., Mikitas M.A. A Mechanism of Stable Development of an Enterprice Basing on Organisation Potential. Upravleniye ehkonomicheskimi sistemami: ehlektronnyj nauchnyj zhurnal = Management of Economic Systems: Electronic Scientific Journal. 2012; (4). Available at: http://uecs.ru/index.php?option=com flexiconte $n t \& v i e w=i t e m s \& i d=1311: 2012-04-28-09-32-19$ (accessed 12.04.2020). (In Russ., abstract in Eng.)

15. Shilova A.M. Conceptualization of Term "Sustainable Development of Manufacturing Company". Master's Journal. 2014; (2):287-296. Available at: http://vestnik.pstu.ru/ $\mathrm{mj} /$ archives/?id=\&folder_id=4322 (accessed 12.09.2020). (In Russ., abstract in Eng.)

16. Laureen E. Global Governance and Sustainability Indicators: The Politics of Expert Knowledge. In: Handbook of Critical Policy Studies. 2016. p. 341-357. (In Eng.) DOI: $10.4337 / 9781783472352.00027$

17. Gordienko A.A., Grokhotova K.V., Koroleva I.B. Impact of Sustainable Development Strategies on the Activity of Oil and Gas Companies. Global and Regional Research. 2019; 1(3):225-232. Available at: http://grr-bgu.ru/reader/article.aspx?id=23201 (accessed 18.06.2020). (In Russ., abstract in Eng.)

18. Titov V.S., Haidar A., Kuznetsov A.A. Features of Strategic Management of a Small Enterprise. Vestnik Rossiyskogo universiteta druzhby narodovo Seriya: Inzhenernyye issledovaniya $=$ RUDN Journal of Engineering Researches. 2009; (4):123-125. Available at: $\mathrm{http} / / /$ journals.rudn.ru/engineering-researches/article/view/4831 (accessed 10.09.2020). (In Russ., abstract in Eng.)

19. Milner B., Orlova T. [Small Business: Problems of Organization and Management]. Problemy teorii i praktiki upravleniya $=$ Problems of Management Theory and Practice. 2013; (4):18-30. Available at: https://ptpmag.ru/malyj-biznes-problemy-organizacii-iupravlenija/ (accessed 18.09.2020). (In Russ.)

20. Mosina E.A. Regional Small Business: Requirements and Prospects. Sotsialnaya politika $i$ sotsiologiya = Social Policy and Sociology. 2016; (1):17-23. (In Russ., abstract in Eng.) DOI: https://doi.org/10.17922/2071-3665-2016-15-1-17-23

21. Fadeeva E.A., Margaryan A.A. Features of Strategic Management of Small Enterprises in the Current Conditions. Biznes. Obrazovaniye. Pravo $=$ Business. Education. Law. 2015; (1):56-59. Available at: http://vestnik.volbi.ru/webarchive/130/ yekonomicheskie-nauki/osobennosti-strategicheskogo-upravlenija.html (accessed 20.05.2020). (In Russ., abstract in Eng.)

Submitted 24.12.2020; approved after reviewing 29.01.2021; accepted for publication 09.02.2021. 
About the authors:

Nadezhda D. Guskova, Professor, Department of Management, National Research Mordovia State University (68/1 Bolshevistskaya St., Saransk 430005, Russian Federation), Dr. Sci. (Economics), ORCID: https://orcid.org/0000-0002-2473-9657, Scopus ID: 56646366400,guskov4nd@yandex.ru

Alexandra V. Erastova, Associate Professor, Department of Management, National Research Mordovia State University (68/1 Bolshevistskaya St., Saransk 430005, Russian Federation), Cand. Sci. (Economics), ORCID: https://orcid.org/0000-0003-2920-7112, Scopus ID: 57191528367, erastova.74@inbox.ru

Daria V. Nikitina, Manager, Division of Contextual Advertising, Performance Advertising Department, SberMarketing (19 Vavilova St., Moscow 117997, Russian Federation), ORCID: https://orcid.org/0000-0002-4214-1210, nidaria96@mail.ru

Contribution of the authors:

N. D. Guskova - academic supervision; literature review on the issues under study; development of a model for integrated assessment of the level of sustainable development of small and medium-sized enterprises; generalization of the results.

A. V. Erastova - structural construction of the article; substantiation of the relevance of the problem under study; preparation of the initial version of the text of the article; critical analysis of the materials.

D. V. Nikitina - collection and processing of analytical information; development of a draft program for the introduction of the principles of sustainable development to the strategic management of JSC Leader-Compound.

The authors have read and approved the final version of the manuscript. 
ЭКОНОМИЧЕСКАЯ СОЦИОЛОГИЯ И ДЕМОГРАФИЯ / ECONOMIC SOCIOLOGY AND DEMOGRAPHY

УДК 338.121

DOI: $10.15507 / 2413-1407.115 .029 .202102 .328-354$

http://regionsar.ru

Оригинальная статья / Original article

ISSN 2587-8549 (Print)

ISSN 2413-1407 (Online)

\section{Трансформация бизнеса в условиях цифровой экономики: зарубежный подход и российские возможности}

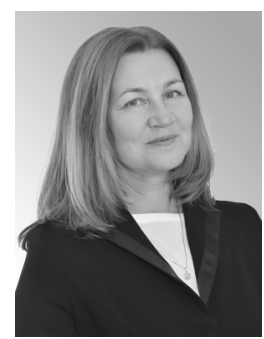

Т. А. Салимова

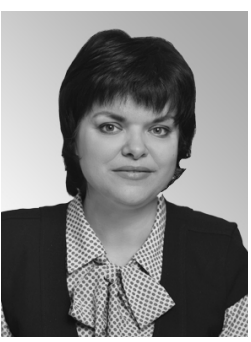

Л. И. Бирюкова*

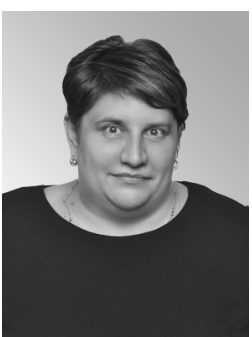

Н. В. Аникина

ФГБОУ ВО «МГУ им. Н. П. Огарёва» (г. Саранск, Российская Федерачия), *lbirukova@yandex.ru

Введение. Наметившийся в последние годы тренд на цифровую трансформацию бизнеса приобретает статус базового условия для эффективного развития российской экономики. В этой связи в фокус исследовательского интереса попадают вопросы готовности компаний к применению технологий Индустрии 4.0, а также вопросы управления рисками и возможностями диджитализации бизнеса. Цель статьи - на основе анализа и систематизации зарубежного опыта цифровой трансформации определить перспективы и ограничения перехода российских предприятий и организаций к Индустрии 4.0 , а также варианты их преодоления в рамках корпоративных стратегий устойчивого развития. Материалы и методы. Авторами проведены статистическая обработка и критический анализ мнений представителей российского бизнеса относительно уровня их осведомленности и видения рисков, возможностей и ограничений применения технологий Индустрии 4.0 в отечественной управленческой практике. Сбор исходных статистических данных был осуществлен в рамках опроса с использованием сервиса Google Docs. Обработка данных выполнена с использованием коэффициента конкордации, критерия согласия Пирсона - хи-квадрата и критерия Крамера.

Результаты исследования. Авторами подтверждена рабочая гипотеза о том, что в условиях цифровой экономики скорость реагирования на глобальные риски, эффективность мер по снижению их негативного влияния на результаты бизнеса зависят от сферы и инновационной направленности деятельности предприятия. При этом выявлена статистически значимая зависимость между отношением отечественных пред-

(C) Салимова Т. А., Бирюкова Л. И., Аникина Н. В., 2021 Контент доступен под лицензией Creative Commons Attribution 4.0 License. This work is licensed under a Creative Commons Attribution 4.0 License. 
приятий к технологиям Индустрии 4.0 и готовностью принимать выгоды и преимущества, связанные с ними. Авторами опровергнута гипотеза о наличии связи между уровнем влияния ключевых барьеров цифровой трансформации российского бизнеса и отношением предприятий к технологиям Индустрии 4.0. На основе обобщения зарубежного опыта предложены варианты разрешения сложившихся противоречий индустриализации российского бизнеса.

Обсуждение и заключение. Результаты исследования подтвердили, что российская экономика на пути перехода к цифровому обществу столкнулась с теми же проблемами и ограничениями, что и большинство стран мира. Их преодоление возможно только в рамках совместных усилий правительственных структур, бизнес-сообщества и социальных институтов. Результаты исследования могут быть использованы федеральными и региональными органами власти для продвижения Национальной программы «Цифровая экономика Российской Федерации» и Национальной технологической инициативы.

Ключевые слова: менеджмент качества, риски и возможности, цифровая трансформация, технологии Индустрии 4.0, устойчивое развитие бизнеса

Авторы заявляют об отсутствии конфликта интересов.

Финансирование. Статья подготовлена при финансовой поддержке гранта РФФИ № 19-010-00968 «Методология и инструментарий цифровизации управления качеством системы образования и обеспечения устойчивого развития экономических агентов».

Для цитирования: Салимова, Т. А. Трансформация бизнеса в условиях цифровой экономики: зарубежный подход и российские возможности / Т. А. Салимова, Л. И. Бирюкова, Н. В. Аникина. - DOI 10.15507/2413-1407.115.029.202102.328-354 // Регионология. $-2021 .-$ Т. 29, № 2. - С. 328-354.

\title{
Business Transformation in the Digital Economy: The Foreign Approach and Russian Opportunities
}

\author{
T. A. Salimova, L. I. Biryukova*, N. V. Anikina \\ National Research Mordovia State University (Saransk, Russian Federation), \\ *lbirukova@yandex.ru
}

Introduction. The trend of digital transformation of business that has emerged in recent years is gaining the status of a basic condition for the effective development of the Russian economy. In this regard, the focus of research interest is on the readiness of companies to use Industry 4.0 technologies, as well as issues of risk management and business digitalization opportunities. The purpose of the study is to analyze and systematize the foreign experience of digital transformation in order to assess the prospects and limitations of the transition of Russian enterprises and organizations to Industry 4.0, as well as the options for overcoming them in the framework of corporate strategies for sustainable development.

Materials and Methods. The authors carried out statistical processing and critical analysis of the opinions of Russian business people about their level of awareness and vision of the risks, opportunities, and limitations of the use of Industry 4.0 technologies in Russian management practice. The initial statistical data were collected as part of a survey using the Google Docs service. Data processing was performed using the concordance coefficient, the Pearson's chi-squared test, and the Cramér-von Mises criterion. 
Results. The authors have corroborated the hypothesis that in the digital economy, the speed of response to global risks, the effectiveness of measures to reduce their negative impact on business results depends on the scope and innovation focus of the enterprise. At the same time, a statistically significant relationship has been revealed between the attitude of Russian enterprises to Industry 4.0 technologies and their willingness to accept the benefits and advantages associated with them. The authors have refuted the hypothesis that there is a connection between the level of influence of the key barriers to the digital transformation of Russian business and the attitude of enterprises to Industry 4.0 technologies. On the basis of generalized foreign experience, the authors have proposed options for resolving the existing contradictions in the industrialization of Russian business.

Discussion and Conclusion. The results of the study have corroborated that the Russian economy faced the same problems and limitations as most countries of the world on the way to transition to a digital society. Overcoming them is possible only through joint efforts of governmental structures, the business community, and social institutions. The research results can be used by federal and regional authorities to promote the National Program "Digital Economy of the Russian Federation" and the National Technology Initiative.

Keywords: quality management, risks and opportunities, digital transformation, Industry 4.0 technologies, sustainable business development

\section{The authors declare that there is no conflict of interest.}

Funding. The article was done with the financial support from the Russian Foundation for Basic Research, grant No. 19-010-00968 "Methodology and Tools for Digitalization of Quality Management of the Education System and Ensuring Sustainable Development of Economic Agents".

For citation: Salimova T.A., Biryukova L.I., Anikina N.V. Business Transformation in the Digital Economy: The Foreign Approach and Russian Opportunities. Regionology $=$ Russian Journal of Regional Studies. 2021; 29(2):328-354. DOI: https://doi.org/10.15507/24131407.115.029.202102.328-354

Введение. Неопределенность внешней среды, высокая скорость и непрерывность технологических изменений, новые научные открытия, казавшиеся невозможными в XX в., стали частью повседневной жизни общества и бизнеса вне зависимости от его масштаба, сферы деятельности и территориальной локации. Начиная с 2010 г. главной движущей силой важнейших технологических, социально-экономических и экологических преобразований в мире становится Четвертая промышленная революция и связанные с ней технологии. Тема цифровой трансформации вошла в стратегическую повестку большинства крупных корпораций, а пандемия коронавирусной инфекции COVID-19 придала дополнительный импульс проектам цифровизации в сегменте среднего и малого бизнеса.

Россия позже крупнейших западных экономик встала на путь цифровой трансформации. Тем не менее под влиянием нового технологического цикла отечественные предприятия и организации стали поэтапно включаться в программы индустриальных преобразований, перестройки бизнес-моделей и процессов. В декабре 2020 г. Президент Российской Феде- 
рации В. В. Путин придал этому движению системность, поручив Правительству подготовить стратегии цифровой трансформации для ключевых отраслей российской экономики, с тем чтобы технологии Индустрии 4.0 стали шире применяться в промышленности, коммунальном хозяйстве и транспорте.

На пути перехода к цифровой экономике отечественному бизнесу предстоит найти ответы на следующие вопросы: как запустить процесс трансформации и эффективно им управлять; какие технологические решения смогут обеспечить рост операционной эффективности; когда окупятся инвестиции; какие компетенции необходимо формировать у персонала; как сохранить команду и ее готовность к непрерывным изменениям? При этом предприятия и организации должны быть готовы, с одной стороны, к управлению возникающими рисками, а с другой - к использованию возможностей и перспектив Индустрии 4.0.

Цель статьи - по результатам проведенного исследования определить пути перехода российских предприятий и организаций к Индустрии 4.0 на основе систематизации мер по управлению рисками и возможностями в рамках реализации корпоративных стратегий устойчивого развития.

Обзор литературы. Первое упоминание термина «Индустрия 4.0» имеет отношение к 2011 г. Немецкие ученые Х. Кагерманн, В.-Д. Лукас и В. Вальстер в своей статье, положившей основу исследований феномена Четвертой промышленной революции, рассмотрели процесс смены парадигмы в промышленности через переход к новым бизнес-моделям на основе киберофизических систем, ведущих к трансформации глобальных цепочек создания ценности $^{1}$. Исторический контекст, содержание, движущие факторы, ключевые технологии Четвертой промышленной революции, ее влияние на экономику, экологию, бизнес и общество нашли свое отражение в многочисленных исследованиях Всемирного экономического форума (WEF) и книгах К. Шваба «Четвертая промышленная революция» (2016) и «Технологии четвертой промышленной революции» (2019), ставших мировыми бестселлерами. К. Шваб описывает Индустрию 4.0 как «новые технологии, объединяющие физический, цифровой и биологический миры, влияющие на все дисциплины, экономики и отрасли. Эти технологии имеют большой потенциал для того, чтобы подключить миллиарды людей к сети и кардинально повысить эффективность бизнеса и организаций»².

${ }^{1}$ Kagermann H., Lukas W., Wahlster W. Industrie 4.0 - Mit dem Internet der Dinge auf dem Weg zur 4. industriellen Revolution [Электронный ресурс] // VDI Nachrichten. 2011. Issue 13. URL: https://www.dfki.de/fileadmin/user_upload/DFKI/Medien/News_Media/Presse/Presse-Highlights/ vdinach2011a13-ind4.0-Internet-Dinge.pdf (дата обращения: 20.01.2021).

${ }^{2}$ Шваб К. Четвертая промышленная революция. М.: Эксмо, 2016. 138 с.; Industry 4.0: The Future of Productivity and Growth in Manufacturing Industries [Электронный ресурс]. URL: https://www.bcg.com/publications/2015/engineered_products_project_business_industry_4_future productivity_growth_manufacturing_industries.aspx (дата обращения: $20.01 .202 \overline{1})$. 
Высокая скорость происходящих технологических изменений, реальность дизруптивного прорыва, возникновение принципиально новых конкурентоспособных бизнес-моделей, серьезное снижение затрат на вхождение в сегмент цифрового бизнеса обеспечили значительный рост исследовательского интереса в отношении перспектив развития современных промышленных производств, рисков и возможностей, преимуществ и ограничений их перехода к Индустрии 4.0. При этом ряд авторов фокусируют свои исследования на перспективах трансформации конкретных направлений деятельности предприятий и организаций - менеджмента качества, финансовой и производственной деятельности, уделяя особое внимание выявлению взаимосвязей между применением технологий Индустрии 4.0 и инновационной активностью, конкурентоспособностью и устойчивым развитием бизнеса.

Так, в работе Дж. М. Мюллера, Д. Киела, К.-И. Войта отмечается, что Четвертая промышленная революция трансформирует не только промышленное производство, но и направления экономического, экологического и социального характера как составляющие устойчивого развития общества [1]. По мнению Дж. Олаха и соавторов, стратегии организации в области устойчивого развития являются основой внедрения технологий Индустрии 4.0 [2].

В. С. Шин и коллектив авторов [3], Т. А. Салимова, Н. Ш. Ватолкина [4] в своих исследованиях идентифицировали предпосылки, вызовы и перспективы развития менеджмента качества и соответствующей системы предприятия в условиях цифровой трансформации. По мнению Й. Блстаковой и других ученых, цифровизация меняет подходы к управлению предприятием в два этапа: сначала в рамках трансформации действующей системы в цифровую, а затем в рамках переосмысления потребительских ценностей и предпочтений [5].

Особое внимание ученые и практики уделяют изучению реальных и потенциальных результатов развития Индустрии 4.0. Так, основными следствиями перехода к Четвертой промышленной революции для всех видов экономической деятельности К. Шваб называет изменения ожиданий потребителей; совершенствование качества продукции и услуг за счет данных, обеспечивающих рост производительности активов; формирование новых партнерств по мере осознания предприятиями и организациями значимости новых форм сотрудничества; трансформацию операционных моделей в новые цифровые модели ${ }^{3}$ Х. И. Вусканович, В. Куч, В. М. Мижучкович, Т. Герцег, исследуя движущие силы внедрения подходов, обусловленных Индустрией 4.0, в практику промышленных предприятий, определили, что рыночная конкуренция, повышение удовлетворенности потребителей, рост требований партнеров являются более значимыми факторами, нежели финансовые, в частности, потребность в оптимизации расходов и всех видов потерь [6]. Необходимость выживания, сохранения бизнеса и конкурентных

${ }^{3}$ Шваб К. Четвертая промышленная революция. 
позиций, а также обеспечения перехода от традиционных к инновационным бизнес-моделям как ключевых предпосылок перехода к технологиям Четвертой промышленной революции подчеркивается в работах Х. Лази, П. Феттке, Х. Кемпера [7], К. Бурмейстера, Д. Люттгенса, Ф. Т. Пиллера [8], С. Лаудиена, Б. Даксбока [9], А. В. Бабкина с соавторами [10; 11].

Л. Хугес с коллегами отмечают, что дорожная карта перехода к Индустрии 4.0 является сложным и многогранным процессом, поскольку производители, с одной стороны, стремятся к переходу к новым технологиям, а с другой - пытаются сохранить традиционный подход операционной эффективности и фокус на устойчивое развитие [12]. Авторы полагают, что переход к технологиям Четвертой промышленной революции может привести к дестабилизирующим изменениям в производственном секторе в течение следующего десятилетия при отсутствии соответствующих дорожных карт перехода на новые управленческие и организационные практики. По мнению Е. Ю. Андиевой, В. Д. Фильчаковой, рост автоматизации, зависимости от киберфизических систем, больших данных, интернета вещей и искусственного интеллекта отражают необходимость перехода к гибкому, адаптивному и умному производству [13]. Методы, экосистемы и технологии цифрового производства рассмотрены в монографии «Цифровое производство. Методы, экосистемы, технологии» ${ }^{4}$. При этом кардинально меняются подход к управлению персоналом и содержание производственных и обеспечивающих процессов за счет изменения требований к профессиональным компетенциям сотрудников, гибкости и автономности при принятии решений и управлением распределенными командами.

Б. Паньшин [14], Х. Фаторачиан и Х. Каземи [15] в качестве ключевых преимуществ Индустрии 4.0 и возможностей для развития бизнеса на основе применения соответствующих технологий называют следующие: возможность удовлетворения индивидуальных предпочтений потребителей при сокращении стоимости; рост адаптивности производственных процессов и предприятий в целом; улучшение систем коммуникации и обмена информацией, принятия решений, интеграционных процессов и партнерства; повышение производительности труда и ресурсоэффективности. Вопросы оптимизации стоимости производимой продукции и выполняемых работ за счет внедрения технологий Индустрии 4.0 рассмотрены М. Бреттелом, Н. Фредериксеном, Н. Келлером, М. Розенбергом [16], а также С. Эролом, А. Джагером, П. Холдом, К. Оттом, В. Сином [17]. Отдельные исследователи в качестве одной из перспектив развития Индустрии 4.0 выделяют трансформацию рынка труда, появление новых профессий, необходимость изменения подходов к подготовке специалистов. Данный аспект нашел свое отражение в трудах Л. И. Бонкампа и М. Сура [18], К. Отмейера и Е. Хофмана [19], А. И. Рудско-

${ }^{4}$ Цифровое производство. Методы, экосистемы, технологии: моногр. / А. И. Боровков, Л. В. Лысенко, П. Н. Биленко [и др.]. М., 2017. 80 с. 
го, А. И. Боровкова, П. И. Романова, О. В. Колосовой [20], Дж. Тортореллы, Р. Миорандо, Р. Кайядо, Д. Начименто и А. П. Стодачера [21].

Отдельное место в исследованиях занимает раскрытие причин, препятствующих активному внедрению цифровых технологий в практику деятельности предприятий. Так, Н. С. Батиста, Р. И. Мелисио и В. Мендес в качестве одного из барьеров называют необходимость трансформации существующей инфраструктуры предприятия [22]. Исследование, проведенное учеными Высшей школы экономки в 2020 г., рассматривает цифровизацию как фактор, влияющий на изменение организационной структуры крупных компаний ${ }^{5}$. Значительный объем инвестиций, необходимость и сложность изменения организационной культуры, нехватка новых «цифровых» лидеров и специалистов в исследовании Х. Контадора, В. Сатиро, Ж. Контадоpa, М. Спинола были отмечены как факторы, препятствующие цифровой трансформации [23].

В. Л. Да Силва с соавторами выделили барьеры на пути Индустрии 4.0, связанные с недостаточной государственной финансовой поддержкой, слабой технологической инфраструктурой организации, неготовностью менеджмента к организационным изменениям, низким уровнем партнерских отношений с заинтересованными сторонами, нехваткой знаний и опыта персонала [24].

Таким образом, проведенный обзор литературных источников позволил выявить и систематизировать преимущества, получаемые предприятиями и организациями при переходе к Индустрии 4.0, а также барьеры и ограничения на пути к осуществлению данного процесса. Результаты систематизации послужили основой для формулировки и проработки рабочих гипотез настоящего исследования.

Материалы и методы. Методология исследовательской работы основана на использовании общенаучных методов, а также методов сбора, систематизации, статистической обработки и критического анализа мнений представителей российских предприятий и организаций относительно уровня их осведомленности и видения рисков, возможностей и ограничений применения положений концепций Индустрии 4.0 в отечественной управленческой практике.

Рабочими гипотезами, определившими ход и этапы настоящего исследования, стали:

- Н1 - глобальные риски влияют на деятельность любого предприятия и/или организации вне зависимости от территориальной локации, масштаба и сферы деятельности;

- Н2 - скорость реагирования на рисковые события, эффективность программ и мер по снижению негативного влияния на результаты бизнеса за-

${ }^{5}$ Ответ на вызовы цифровизации: госуправление, основанное на данных, «штабная» модель управления и структурный маневр в численности госслужащих: Доклад НИУ ВШЭ [Электронный ресурс] / А. Б. Жулин (рук. авт. кол.), Я. И. Кузьминов; Нац. исслед. ун-т «Высшая школа экономики». М.: Изд. дом Высш. шк. экономики, 2020. URL: https:/www.hse.ru/mirror/pubs/ share/427045188.pdf (дата обращения: 10.02.2021). 
висят от сферы и инновационной направленности деятельности предприятия и/или организации;

- Н3 - существует взаимозависимость между уровнем отношения к технологиям Индустрии 4.0 и готовностью предприятий и/или организаций принимать и использовать связанные с данными технологиями преимущества;

- Н4 - существует взаимозависимость между уровнем отношения к технологиям Индустрии 4.0 и восприимчивостью предприятиями и/или организациями барьеров, сдерживающих цифровую трансформацию общества.

При этом авторы основывались на выводах, полученных по результатам проведенного литературного обзора (табл. 1).

Т а б л и ц а 1. Преимущества и ограничения на пути перехода предприятий и организаций к Индустрии 4.0

$\mathrm{T}$ a b l e 1. Advantages and limitations in the transition of enterprises and organizations to Industry 4.0

Преимущества / Advantages

1. Обеспечение конкурентоспособности в долгосрочной перспективе / Ensuring long-term competitiveness

2. Выход на новые рынки сбыта / Entering new markets

3. Рост производительности труда / Labor productivity growth

4. Обеспечение непрерывности бизнеса / Ensuring business continuity

5. Обеспечение экологической безопасности / Ensuring environmental safety

6. Обеспечение социальной ответственности и социального поведения бизнеса / Ensuring social responsibility and social behavior of business

7. Развитие сетей партнерского взаимодействия со стейкхолдерами / Establishing networks of partnership interaction with stakeholders

8. Возможность противостояния рискам / Ability to withstand risks

9. Внедрение перспективных управленческих подходов / Introduction of advanced management approaches

10. Оптимизация различных видов затрат / Optimization of various types of costs 11. Рост доходности бизнеса / Business profitability growth

12. Усиление влияния потребителей на бизнес-процессы / Growing influence of consumers on business processes
Ограничения / Limitations

1. Отсутствие влияния технологий на производственный процесс и результаты деятельности / No impact of technology on the production process and performance 2. Необходимость значительного объема капиталовложений / Need for a significant amount of capital investment

3. Необходимость значительных организационных/административных усилий / Need for significant organizational / administrative effort

4. Низкий уровень автоматизации и цифровизации процессов / Low level of automation and digitalization of processes

5. Нехватка квалифицированных специалистов / Lack of qualified specialists

6. Низкая цифровая культура руководства / Low digital culture of the management

7. Сопротивление со стороны персонала / Resistance from the staff 
Сбор исходных статистических данных был осуществлен в январе марте 2020 г. в рамках опроса, проведенного с использованием сервиса GoogleDocs. Основными критериями формирования целевой группы респондентов послужили:

а) принадлежность предприятия и/или организации к реальному сектору экономики;

б) отражение пропорций и структуры российской промышленности, а также тренда на увеличение количества малых и средних предприятий и их вклада в ВВП страны до 32,5 \% к 2024 г., заданного в рамках национального проекта «Малое и среднее предпринимательство и поддержка индивидуальной предпринимательской инициативы»;

в) территориальная принадлежность респондентов к регионам с высоким уровнем развития промышленности и торговли.

Ссылка на онлайн-анкету была разослана на 650 официальных электронных адресов предприятий и организаций. В ответ было получено 154 действительных отклика из Республики Мордовия, Республики Татарстан, Тамбовской, Воронежской, Калужской, Свердловской, Нижегородской, Ульяновской, Пензенской и Самарской областей, Пермского края, а также городов Москвы и Санкт-Петербурга.

Качественные характеристики участников опроса представлены в таблице 2. Мнения респондентов можно считать показательными в силу того, что ключевые критерии формирования целевой выборки были соблюдены. Об объективности суждений участников опроса свидетельствует тот факт, что все они так или иначе задействованы в процессах формирования и реализации корпоративных стратегий устойчивого развития, цифровизации и трансформации бизнеса.

Т а б л и ц а 2. Характеристики участников опроса, \%

$\mathrm{T}$ a $\mathrm{b} 1 \mathrm{e}$ 2. Characteristics of the survey participants, $\%$

\begin{tabular}{|c|c|}
\hline $\begin{array}{l}\text { Вид экономической деятельности / Tyре of } \\
\text { economic activity }\end{array}$ & $\begin{array}{c}\text { Процентное соотношение / } \\
\text { Percentage ratio }\end{array}$ \\
\hline 1 & 2 \\
\hline Машиностроение / Mechanical engineering & 42 \\
\hline $\begin{array}{l}\text { Химическая промышленность / Chemical } \\
\text { industry }\end{array}$ & 12 \\
\hline $\begin{array}{l}\text { Пищевая промышленность и АПК / Food } \\
\text { industry and agroindustrial complex }\end{array}$ & 12 \\
\hline $\begin{array}{l}\text { IT и телекоммуникации / IT and } \\
\text { telecommunications }\end{array}$ & 11 \\
\hline Энергетика / Power engineering & 7 \\
\hline Металлургия / Metallurgy & 4 \\
\hline
\end{tabular}


Окончание табл. 2 / End of table 2

\begin{tabular}{l|l}
\hline \multicolumn{1}{c|}{1} & 2 \\
\hline $\begin{array}{l}\text { Проектирование и строительство / Design and } \\
\text { construction }\end{array}$ & 3 \\
Услуги / Services & 9 \\
\hline
\end{tabular}

Размер бизнеса / Size of business

Процентное соотношение /

Percentage ratio

Крупный / Big

Средний / Medium

Малый / Small
31

41

28

Процентное соотношение /

Percentage ratio

Топ-менеджер / Top Manager 49

Руководитель среднего звена / Middle Manager 34

Специалист / Specialist

Респондентам была предложена структурированная анкета из 19 вопросов, объединенных в два раздела. Вопросы раздела А (6 вопросов) использовались для определения качественных параметров опрашиваемой аудитории для целей ее сегментации и контроля за обеспечением репрезентативности выборки. Раздел В содержал 13 вопросов, позволивших выявить наиболее значимые риски, оказывающие влияние на результаты бизнеса, а также систематизировать мероприятия по управлению ими; дать оценку практических аспектов применения инновационных технологий, методов, принципов и подходов, характерных для Индустрии 4.0; определить возможности и ограничения, перспективы и последствия интеграции ключевых положений концепции Индустрии 4.0 в деятельность российских предприятий и организаций разных сфер.

Для статистической обработки полученных в ходе опроса данных были использованы:

- коэффициент конкордации $(W)$ как инструмент оценки согласованности экспертных мнений;

- критерий согласия Пирсона - хи-квадрат $\left(\chi^{2}\right)$, позволяющий подтвердить наличие или отсутствие связи между двумя качественными признаками;

- критерий Крамера $(V)$ как инструмент количественной оценки степени (силы) связи между двумя качественными признаками.

Полученные в ходе исследования результаты были доведены до сведения респондентов с целью разработки рекомендаций по цифровой трансформации систем менеджмента и бизнеса предприятий и организаций в целом.

Результаты исследования. Сценарий исследовательской работы был выбран исходя из поставленных целей и рабочих гипотез. Первоначально респондентам было предложено определить ключевые для их отрасли и/или бизнеса 
риски и оценить степень их влияния на результаты деятельности предприятия в условиях цифровой трансформации общества. Основой для разработки данного раздела анкеты послужил рейтинг корпоративных рисков, составленный Allianz Global Corporate \& Specialty ${ }^{6}$. Для обеспечения полноты исследования в число оцениваемых были включены риски физического воздействия (пожары или ураганы), а также инциденты в IT-сфере; риски, носящие преднамеренный характер, и случайные риски; риски, являющиеся результатом деятельности самого предприятия, его клиентов и партнеров, а также внешние риски, источники которых относятся к геополитической и макроэкономической сферам. Основным критерием включения того или иного риска в анкету стала масштабность возможных финансовых потерь из-за прерывания бизнеса ${ }^{7}$

Обобщая мнения респондентов относительно рисков, входящих в Allianz Risk Barometer, авторам в первую очередь удалось оценить уровень сформированности мнения российской предпринимательской и производственной среды по данному вопросу, а также степень его согласованности с мнением международного бизнес-сообщества.

Результаты ранжирования ключевых бизнес-рисков с точки зрения влияния на деятельность российских предприятий - участников опроса представлены в таблице 3. Рассчитанный коэффициент конкордации ( $W=0,667)$ позволяет сделать вывод о высокой согласованности мнений респондентов относительно степени влияния глобальных рисков на деятельность предприятия. Вычисленное значение $\chi^{2}(924,65)$ превышает табличное значение $\chi^{2}(183,96)$ при уровне значимости 5 \%. Найденный коэффициент конкордации является статистически значимым и позволяет подтвердить гипотезу (H1) о влиянии глобальных рисков на деятельность предприятий и организаций вне зависимости от их территориальной локации, масштаба и сферы деятельности.

Риски, с которыми сегодня сталкиваются российские предприятия и организации, становятся все более сложными. Наибольшие опасения вызывают изменения в законодательстве (средний ранг 8,21), новые технологии $(7,96)$, макроэкономические события $(7,96)$, утрата репутации или ценности бренда $(7,21)$ и прерывание бизнеса $(7,16)$. Полученные ранги позволяют сделать вывод о том, что именно развитие новых технологий в условиях перехода к цифровой экономике в сочетании с экономической и правовой нестабильностью способствует трансформации традиционных для российских предприятий бизнес-моделей, заставляет приспосабливаться к новым реалиям и отвечать на вызовы современности.

${ }^{6}$ Allianz Risk Barometer 2020 [Электронный pecypc]. URL: https://www.agcs.allianz.com/ content/dam/onemarketing/agcs/agcs/reports/Allianz-Risk-Barometer-2020-Appendix.pdf (дата обращения: 20.01.2021).

7 The Global Risks Report 2020 [Электронный ресурc]. URL: http://www3.weforum.org/docs/ WEF Global Risk_Report 2020.pdf; Political Risk Map 2020: Trade Tensions Threaten Political Stability [Электронный ресурc]. URL: https://www.marsh.com/us/insights/research/political-riskmap-2020.html (дата обращения: 15.01.2021). 
Т а б л и ц а 3. Оценка степени влияния глобальных рисков на деятельность предприятия

$\mathrm{T} \mathrm{a} \mathrm{b}$ l e 3. Assessment of the impact of global risks on the company's activities

\begin{tabular}{|c|c|c|c|c|c|c|c|c|c|c|c|}
\hline $\begin{array}{l}\text { Вид риска / } \\
\text { Tyре of risk }\end{array}$ & & & $\begin{array}{l}\text { Личч } \\
\text { Num }\end{array}$ & $\begin{array}{l}\text { ств } \\
\text { per o }\end{array}$ & $\begin{array}{l}\text { paH } \\
\text { f ran }\end{array}$ & $\begin{array}{l}\text { говь } \\
\mathrm{k} \text { ass }\end{array}$ & $\begin{array}{l}\text { IX ol } \\
\text { essn }\end{array}$ & $\begin{array}{l}\text { eeноr } \\
\text { ents }\end{array}$ & & & $\begin{array}{l}\text { Средний } \\
\text { ранг / } \\
\text { Average } \\
\text { rank }\end{array}$ \\
\hline $\begin{array}{l}\text { Киберриски } \\
\text { и киберинциденты / Cyber } \\
\text { risks and cyber incidents }\end{array}$ & 6 & 15 & 53 & 50 & 8 & 4 & 2 & 6 & 6 & 4 & 3,99 \\
\hline $\begin{array}{l}\text { Прерывание бизнеса, } \\
\text { включая цепочки поставок / } \\
\text { Business interruption, } \\
\text { including supply chain } \\
\text { disruption }\end{array}$ & 1 & 1 & 1 & 10 & 15 & 29 & 29 & 30 & 16 & 22 & 7,16 \\
\hline $\begin{array}{l}\text { Изменения } \\
\text { в законодательстве / } \\
\text { Changes in the legislation }\end{array}$ & 0 & 0 & 1 & 0 & 4 & 14 & 27 & 37 & 38 & 33 & 8,21 \\
\hline $\begin{array}{l}\text { Природные катастрофы / } \\
\text { Natural disasters }\end{array}$ & 61 & 44 & 15 & 19 & 8 & 3 & 0 & 1 & 1 & 2 & 2,37 \\
\hline $\begin{array}{l}\text { Высокая волатильность } \\
\text { рынка / High market } \\
\text { volatility }\end{array}$ & 1 & 1 & 8 & 22 & 80 & 29 & 10 & 2 & 1 & 0 & 5,09 \\
\hline $\begin{array}{l}\text { Техногенные катастрофы } \\
\text { (пожары, взрывы) / Man- } \\
\text { made disasters (fires, } \\
\text { explosions) }\end{array}$ & 46 & 39 & 19 & 34 & 13 & 2 & 1 & 0 & 0 & 0 & 2,60 \\
\hline $\begin{array}{l}\text { Изменение климата / } \\
\text { Climate change }\end{array}$ & 37 & 53 & 48 & 8 & 2 & 1 & 1 & 1 & 3 & 0 & 2,45 \\
\hline $\begin{array}{l}\text { Утрата репутации или } \\
\text { ценности бренда / Loss of } \\
\text { reputation or brand value }\end{array}$ & 2 & 0 & 3 & 4 & 11 & 37 & 32 & 23 & 22 & 20 & 7,21 \\
\hline $\begin{array}{l}\text { Новые технологии / New } \\
\text { technologies }\end{array}$ & 0 & 1 & 4 & 0 & 6 & 25 & 25 & 22 & 29 & 42 & 7,96 \\
\hline $\begin{array}{l}\text { Макроэкономические } \\
\text { coбытия / Macroeconomic } \\
\text { developments }\end{array}$ & 0 & 0 & 2 & 7 & 7 & 10 & 27 & 32 & 38 & 31 & 7,96 \\
\hline
\end{tabular}

Большинство респондентов отметили, что так или иначе предпринимают действия, направленные на противостояние рискам (рис. 1). В первую очередь речь идет о тех из них, что непосредственно относятся к зонам ответственности и влияния предприятия (новые технологии $-43,4 \%$ peспондентов, прерывание бизнеса, включая цепочки поставок - 30,3, утрата репутации или ценности бренда $-27,6$, киберриски и киберинциденты $-18,4 \%)$. 
Новые технологии / New technologies

Прерывание бизнеса, включая цепочки поставок / Business interruption, including supply chain disruption

Утрата репутации или ценности бренда / Loss of reputation or brand value

Киберриски и киберинциденты / Cyber risks and cyber incidents

Изменения в законодательстве / Changes in the legislation

Макроэкономические события / Macroeconomic developments

Техногенные катастрофы (пожары, взрывы) / Man-made disasters (fires, explosions)

Высокая волатильность рынка / High market volatility

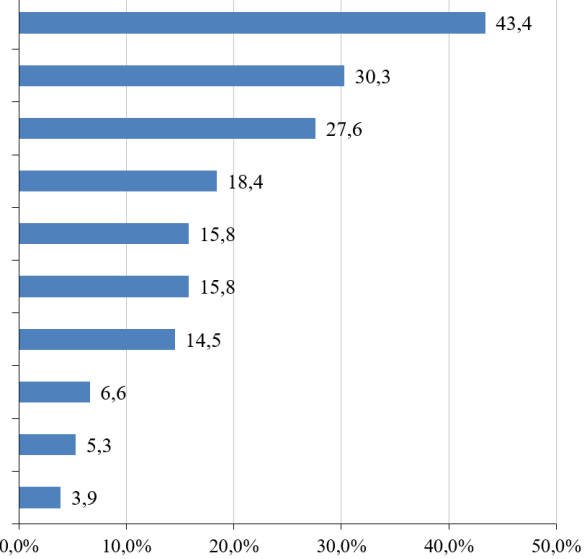

Природные катастрофы / Natural disasters

Изменение климата / Climate change

$0,0 \%$

$10,0 \%$

$20,0 \%$

$30,0 \%$

$50,0 \%$

Р и с. 1. Распределение ответов на вопрос об управлении рисками в деятельности предприятий, \%

F i g. 1. Distribution of answers to the question about risk management in the activities of enterprises, $\%$

В то же время готовность предприятий инновационного сектора к управлению рисками и изменениям, связанным с переходом к технологиям Индустрии 4.0, значительно выше, чем у предприятий традиционных отраслей. Об этом свидетельствует подтвержденная в рамках исследования гипотеза (H2) о том, что скорость реагирования на рисковые события, эффективность программ и мероприятий по снижению их негативного влияния на результаты бизнеса во многом зависит от отраслевой специфики предприятия.

Для анализа нами были использованы критерий хи-квадрат ( $\chi 2)$ на 5-процентном уровне значимости и V-критерий (табл. 4).

Полученные в результате расчетов данные свидетельствуют о том, что такие высокотехнологичные отрасли, как IT и телекоммуникации, машиностроение и химическая промышленность, в большей степени подвержены влиянию разнообразных видов рисков. В целях сохранения непрерывности и устойчивости своего бизнеса они готовы на системной основе разрабатывать и реализовывать стратегии и тактики риск-менеджмента. Для предприятий традиционных сфер деятельности, таких как сельское хозяйство, металлургия, энергетика, это менее характерно.

Особое внимание предприятиям инновационных сфер деятельности приходится обращать на такие виды рисков, как «новые технологии» и «киберриски и киберинциденты», поскольку вероятные потери от нарушения неприкосновенности данных, хакерских атак, перерывов в производстве вследствие IT-инцидентов или ошибок в использовании новых технологий, материалов и искусственного интеллекта крайне высоки для данного типа бизнеса. 


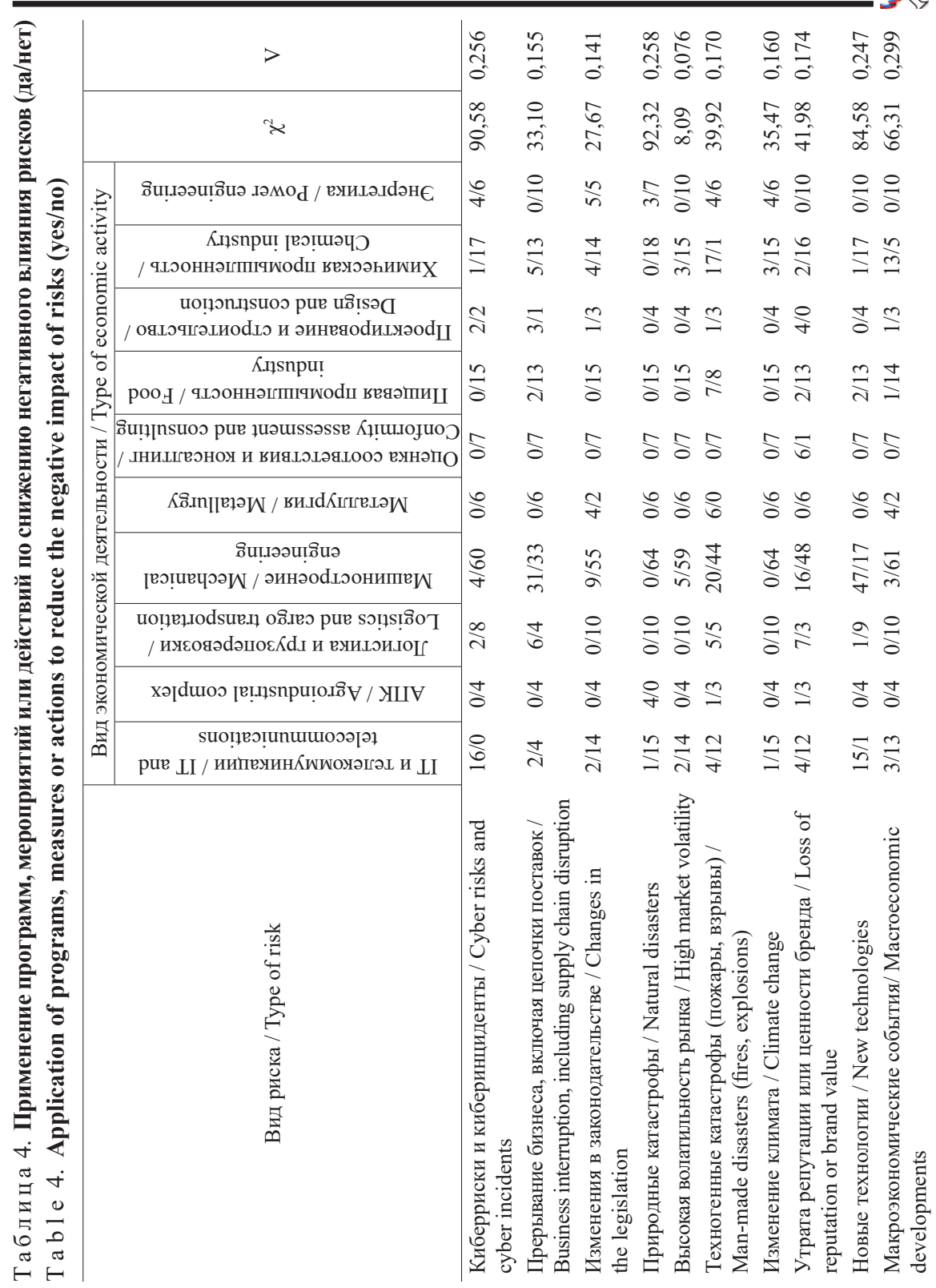


В эпоху цифровизации менеджмент риска в сфере информационной и технологической безопасности - это одновременно вопросы конкурентных преимуществ и устойчивости бизнеса.

Вычисленные значения $\chi^{2}$ для данных видов рисков $(90,58$ - киберриски и киберинциденты и 84,58 - новые технологии) превышают табличное значение $\chi^{2}(16,92)$ при уровне значимости $5 \%$, что подтверждает наличие связи между оценками рисков, разработкой и реализацией программам в области риск-менеджмента и видом экономической деятельности того или иного субъекта хозяйствования (гипотеза Н2).

Для обеспечения устойчивости бизнеса предприятия на системной основе применяют инструменты менеджмента качества (59,2 \%), бережливого производства и управления талантами (по 36,8 \% соответственно), рискменеджмента $(34,2 \%)$, а также совершенствуют механизмы внутреннего контроля в рамках интегрированных систем менеджмента $(31,6 \%)$ и партнерских отношений с различными группами заинтересованных сторон (26,3\%) (рис. 2).

Менеджмент качества / Quality management Привлечение и удержание талантов / Attracting and retaining top talent

Бережливое производство / Lean production

Управление рисками / Risk management

Интегрированные системы менеджмента / Integrated management systems

Партнерство со стейкхолдерами / Partnership with stakeholders

Менеджмент знаний и инноваций / Knowledge and innovation management

Социальная ответственность / Social responsibility

Экологический менеджмент / Environmental management

Системное лидерство / Systemic leadership

Развитие организационной культуры / Development of organizational culture

Менеджмент непрерывности бизнеса / Business continuity management

Затрудняюсь ответить / Not sure

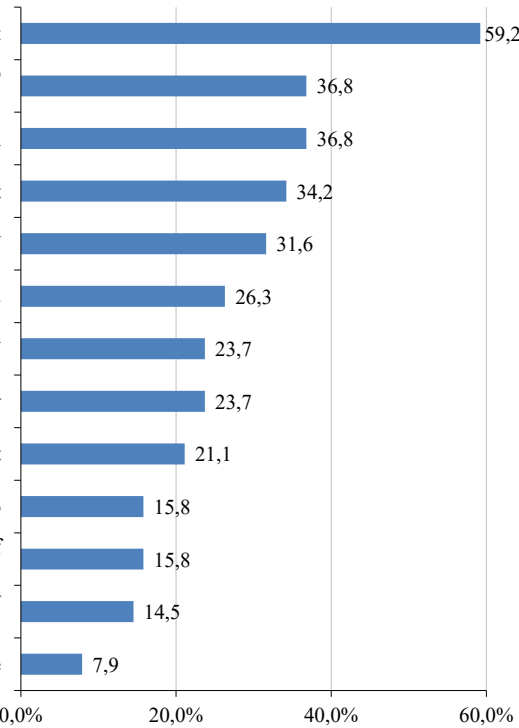

Р и с. 2. Распределение ответов на вопрос о применении управленческих подходов, принципов и практик в деятельности предприятий, \%

F i g. 2. Distribution of the answers to the question about the application of managerial approaches, principles, and practices in the activities of enterprises, $\%$ 
Применение данных практик российские предприятия связывают в первую очередь с концепциями устойчивого развития $(40,8 \%)$ и устойчивой конкурентоспособности (35,5 \%). Данная ситуация закономерна ввиду практического их использования с момента вступления в силу Указа Президента Российской Федерации № 440 от 01.04.1996 «О Концепции перехода Российской Федерации к устойчивому развитию». Применение положений концепций Индустрии 4.0 в отечественной управленческой практике носит ограниченный, фрагментарный характер. Тем не менее понимание у российского бизнес-сообщества того, что Четвертая промышленная революция неизбежна, на сегодняшний день практически сформировано. Об этом свидетельствует тот факт, что 75 \% опрошенных рассматривают технологические вызовы Индустрии 4.0 в качестве возможностей для развития предприятия и результатов его деятельности, $6,6-$ в качестве потенциальных угроз, а 18,4 \% респондентов считают, что вызовы носят нейтральный по отношению к их бизнесу характер.

Основываясь на данном факте, дальнейший анализ общности и различий в оценках потенциальных выгод от применения технологий Индустрии 4.0 в практике деятельности российских предприятий (гипотеза Н3) и значимости причин, сдерживающих их инновационные преобразования (гипотеза Н4), был проведен для трех групп респондентов, демонстрирующих положительное, нейтральное или отрицательное отношение к Индустрии 4.0. Результаты, полученные с использованием критерия хи-квадрат $(\chi 2)$ на 5-процентном уровне значимости, а также метода группировки, представлены в таблицах 5 и 6.

Вычисленные значения $\chi^{2}$ для всех трех групп респондентов по всем типам потенциальных выгод (табл. 5) превышают табличное значение $\chi^{2}(15,51)$ при уровне значимости 5 \%, что подтверждает гипотезу (H3) о наличии статистически значимой зависимости между уровнем отношения к технологиям Индустрии 4.0 и готовностью принимать и использовать связанные с ними преимущества. При этом чем четче респондент демонстрирует свое отношение к вопросам индустриальной трансформации, тем более осознанными являются его знания об инновационных технологиях, материалах, практиках и подходах, а значит выше способность получать положительный эффект от их применения.

Так, средний ранг восприятия потенциальных выгод, связанных с Индустрией 4.0, у респондентов с позитивным настроем составил 3,499; у респондентов с негативным настроем - 2,378; у респондентов с нейтральным настроем - 2,122. При этом позитивно настроенные респонденты связывают технологии Индустрии 4.0 в первую очередь с ростом производительности труда (средний ранг - 4,061), долгосрочным обеспечением конкурентоспособности бизнеса $(4,043)$ и возможностью расширения рынка сбыта $(3,974)$. Негативно настроенные респонденты, осознавая всю полноту рисков и угроз, ждут от Индустрии 4.0 оптимизации управленческих подходов (средний ранг - 3,000); структуры и объема операционных затрат $(2,818)$, в том числе за счет роста производительности труда $(2,727)$. 


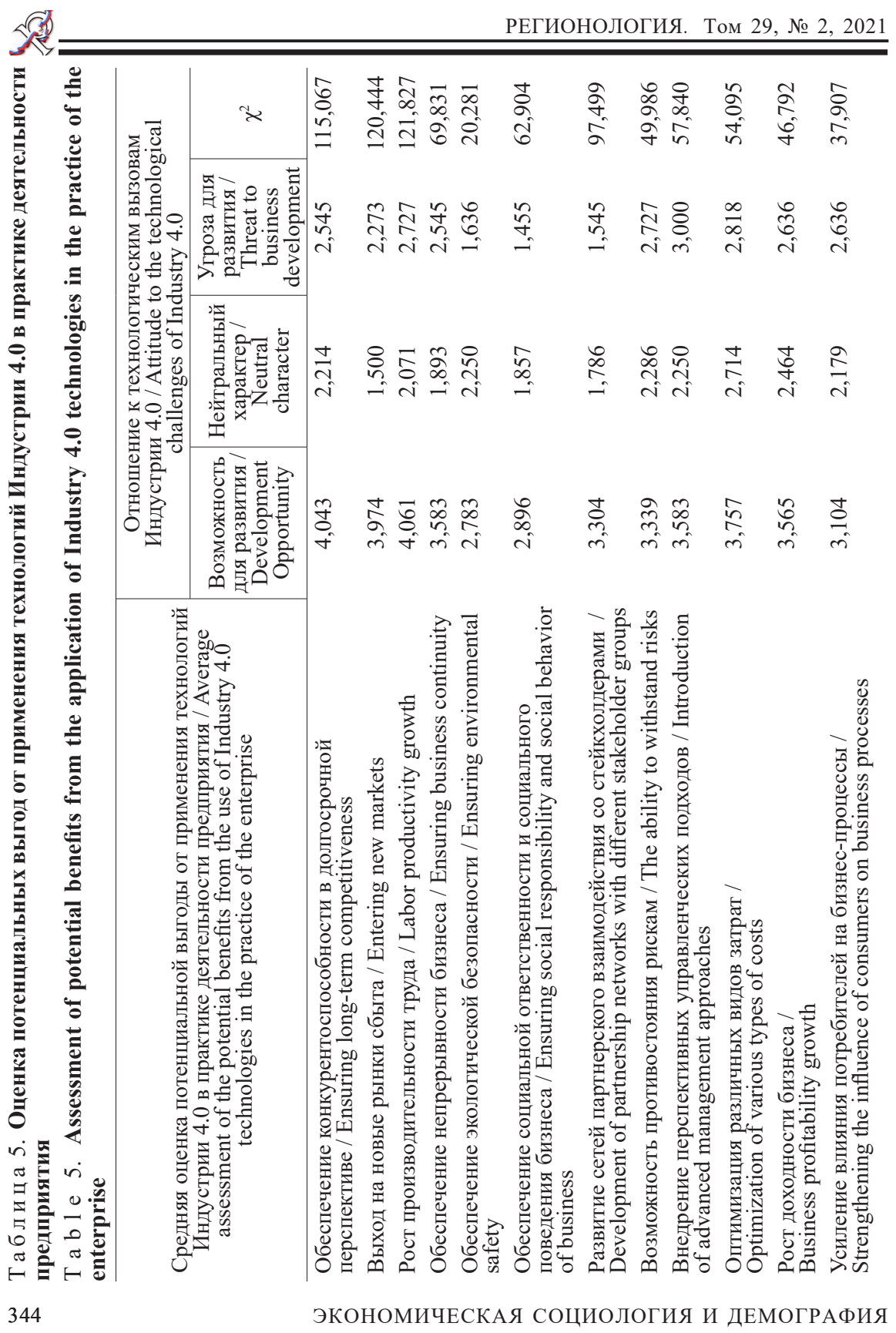


Оценки третьей группы респондентов, считающих, что вызовы Индустрии 4.0 носят нейтральный по отношению к их бизнесу характер, по всем типам потенциальных выгод можно интерпретировать как хаотичные / нестабильные / разнонаправленные. На наш взгляд, за нейтральным отношением к вызовам Индустрии 4.0 в большей мере стоит незнание, непонимание или отсутствие практического опыта применения новых технологий, материалов и подходов. Об этом свидетельствует тот факт, что средний ранг потенциальных выгод у данной группы респондентов значительно ниже, чем у респондентов с негативным настроем относительно Индустрии 4.0. Исключение составляют только выгоды, ставшие уже традиционными для российского бизнеса: обеспечение экологической безопасности - 2,250, обеспечение социальной ответственности и социального поведения бизнеса $-1,857$, развитие сетей партнерского взаимодействия с различными группами заинтересованных сторон $-1,786$.

Тем не менее во многом благодаря особой роли государства в выборе и поддержке курса на построение цифровой экономики большинство предприятий осведомлены о сущности и содержании передовых технологий и элементов цифровизации, характерных для Индустрии 4.0. В первую очередь речь идет об искусственном интеллекте (50,0\% респондентов), BigData $(48,7 \%$ ), роботизации и Internet of things (IоT) (по 44,7 \% соответственно). Однако реальный уровень вовлеченности в Четвертую промышленную революцию и практическое применение ее ключевых технологий остается крайне низким. Более половины опрошенных считают свидетельством цифровой трансформации своей работы хранение и статистическую обработку данных $(36,8 \%)$, а также применение передовых материалов и технологий аддитивного производства $(14,5 \%)$. При этом $35,5 \%$ респондентов не смогли или затруднились назвать применяемые ими технологии Индустрии 4.0.

Интересно, что топ-менеджмент оценивает уровень использования цифровых технологий в работе своих компании значительно выше, нежели руководители среднего звена и рядовые специалисты. На наш взгляд, это может указывать на необоснованный оптимизм менеджеров высшего звена относительно технологий Индустрии 4.0 либо на низкий уровень осведомленности персонала о реализуемых в компаниях цифровых проектах и стратегиях. Иными словами, результаты проведенного опроса еще раз подтвердили, что глубина проникновения цифровой трансформации в российских компаниях сильно переоценена. Большинство предприятий находится на начальном этапе разработки такой стратегии и пересмотра системы управления бизнесом на основе технологий Индустрии 4.0, рассчитывая в первую очередь улучшить системные факторы производства, включая производительность труда, структуру и численность занятых, конкурентную ситуацию и др. В этой связи ждать быстрых изменений как минимум некорректно. Однако процесс цифровой перестройки российского бизнеса неизбежен, поскольку это единственный способ его адаптации к изменениям, происходящим в мире. 
Для проработки гипотезы Н4 сгруппируем мнения респондентов, исходя из их отношения к Индустрии 4.0 по вопросам, касающимся ключевых причин, сдерживающих и/или создающих барьеры для цифровой трансформации российского бизнеса (табл. 6).

Вычисленные значения $\chi^{2}$ для всех трех групп респондентов по сдерживающим причинам/барьерам (табл. 6) неоднородны: для четырех причин они превышают табличное значение $\chi^{2}(15,51)$ при уровне значимости $5 \%$, а для трех причин - не превышают. Это опровергает гипотезу (H4) о наличии связи между оценкой степени влияния причин, препятствующих индустриальной трансформации бизнеса, и уровнем отношения респондентов к технологиям Индустрии 4.0.

Респонденты считают, что ключевыми барьерами цифровой трансформации российского бизнеса являются:

a) необходимость значительных инвестиций в программное обеспечение, технику, НИОКР. Для данной причины расчетное значение $\chi^{2}(6,372)$ ниже табличного значения $(15,51)$, при этом средние ранги у всех трех групп респондентов являются максимальными или близки к максимальным $(3,878,3,536$ и 3,636 соответственно). Это подтверждает серьезные опасения российских предприятий по поводу того, что в условиях ограниченных объемов свободных денежных средств без соответствующей государственной поддержки интенсивность запуска механизма цифровой трансформации и внедрения инноваций будет осуществляться крайне медленно и неэффективно;

б) нехватка квалифицированных специалистов, опыта внедрения технологий и компетенций в сфере ИКТ. Расчетное значение $\chi^{2}(8,199)$ ниже табличного значения $(15,51)$, средние ранги у всех трех групп респондентов близки к максимальным (3,383; 3,429 и 3,455 соответственно). Наличие данной проблемы признали представители предприятий как традиционного, так и инновационного секторов производства, с позитивным, негативным и нейтральным отношением к технологиям Индустрии 4.0. Только $15 \%$ респондентов считают, что обладают компетенциями, необходимыми для продвижения новых цифровых технологий, 64 - не подтвердили наличие подобных компетенций, а 21 \% и вовсе затруднились дать такую оценку;

в) низкий уровень автоматизации и цифровизации управленческих и производственных процессов. Расчетное значение $\chi^{2}(32,664)$ превышает табличное значение $(15,51)$; анализируемые переменные связаны между собой, при этом разброс в уровне средних рангов оценок разных групп респондентов незначителен $(3,113,4,107,3,182$ соответственно). Полученные расчеты коррелируют с информацией о практическом применении технологий, поддерживающих развитие Индустрии 4.0: на сегодняшний день предприятия-участники опроса освоили лишь базовые и относительно простые цифровые технологии, к глубокой автоматизации и реструктуризации бизнес-процессов на основе передовых цифровых технологий приступили лишь единицы из них; 


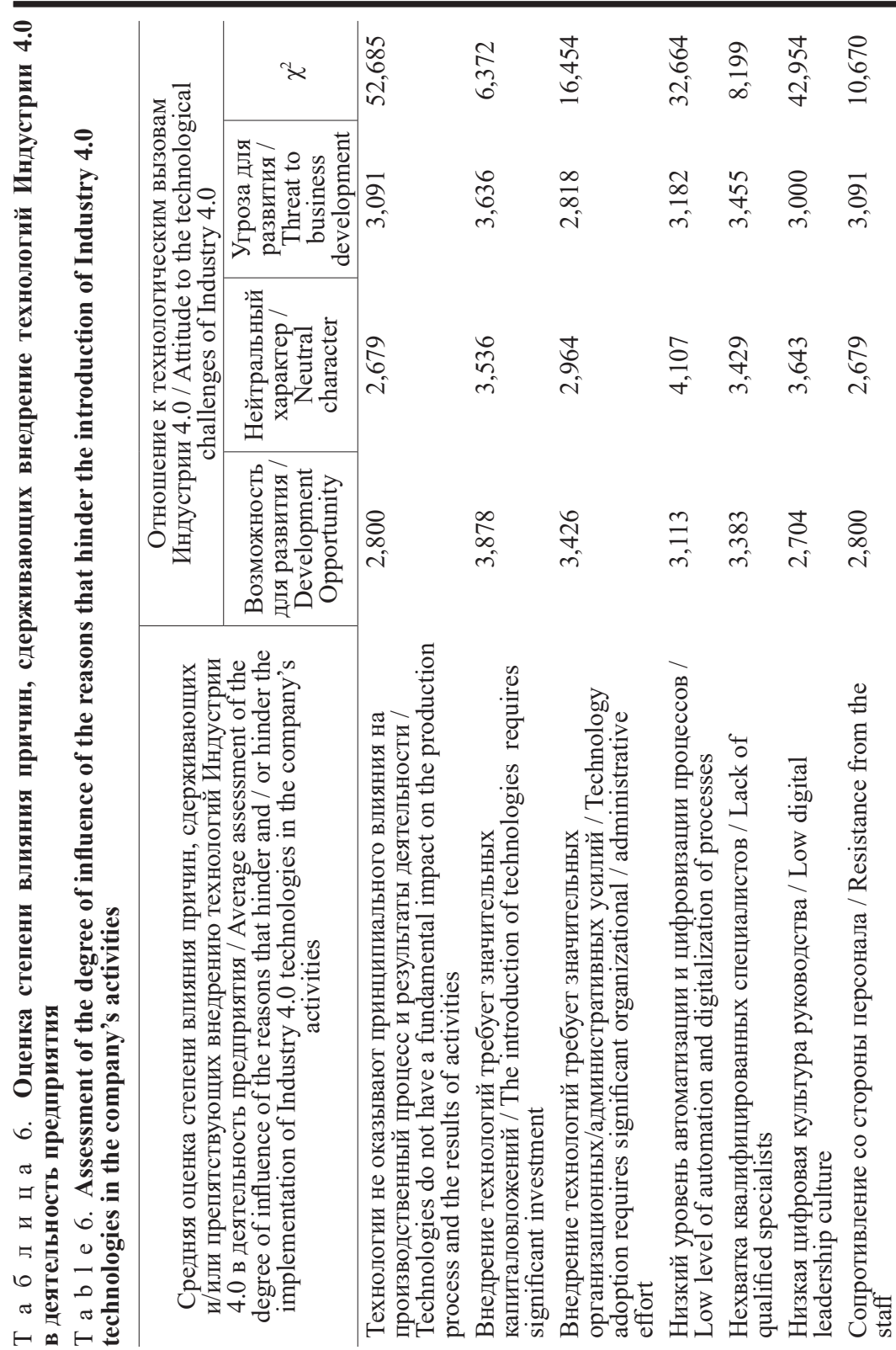


г) необходимость значительных организационных/административных усилий для внедрения новых технологий. Расчетное значение $\chi^{2}(16,454)$ превышает табличное значение $(15,51)$; анализируемые переменные связаны между собой, при этом средние ранги оценок полностью соответствуют уровню отношения и готовности к применению технологий Индустрии 4.0, характерному для соответствующей группы респондентов (от 3,426 у респондентов с позитивным отношением до 2,818 у респондентов с негативным отношением). Все опрошенные сошлись во мнении, что даже при наличии необходимых ресурсов скорость цифровой трансформации их компаний будет ограничена внутренней резистентностью, а также трудностями, связанными с изменениями существующих бизнес-процессов и интеграцией цифровых технологий с «традиционными» подходами к принятию управленческих решений. Преодоление данного барьера возможно только при условии серьезной заинтересованности со стороны руководства, вовлеченности персонала предприятий и организаций, а также повышения цифровой культуры и грамотности. Иными словами, по мнению представителей российских предприятий инновационных секторов экономики успех их цифрового скачка будет зависеть не только от оптимизации процессов и применяемых технологий, но и от целостности и аутентичности корпоративной культуры, обеспечивающей гармонизацию действий персонала и применяемых им технологий. Участникам опроса видится, что развитие корпоративной культуры в данном ключе, а также снятие административных, социальных и иных барьеров для самореализации человека можно будет обеспечить за счет социализации и гуманизации практики управления как на уровне отдельных предприятий и организаций, так и на отраслевом и государственном уровнях.

Обсуждение и заключение. По результатам проведенного исследования можно сделать вывод о том, что экономика Российской Федерации в лице ее бизнес-сообщества на пути перехода к цифровому обществу будущего столкнулась с теми же проблемами и ограничениями, что и большинство стран мира. Это отсутствие инвестиций, необходимых для проведения технологического перевооружения и цифровизации производств; недостаток кадров, готовых работать со smart-системами; необходимость оперативного изменения законодательства, регулирующего общественные и экономические отношения в условиях всеобщей диджитализации; неготовность общества к принятию и активному участию в продвижении данной доктрины в социуме, в том числе в части этических аспектов и вопросов кибербезопасности взаимоотношений «человек - машина» и др. Сегодня Россия делает первые шаги по их преодолению в рамках реализации Стратегии развития информационного общества на период до 2030 г. и инициатив Национальной программы «Цифровая экономика Российской Федерации». При этом прогресс в вопросах цифровой трансформации на национальном уровне может быть достигнут только за счет применения госструктурами и бизнес-сообществом 
комплексных решений и практик как в части внедрения цифровых технологий, так и в части формирования цифровой культуры в обществе.

Результаты данного исследования могут быть использованы всеми участниками трансформационного процесса в части идентификации и развития институциональных, кадровых, финансовых, инфраструктурных и иных условий и факторов цифровизации экономики Российской Федерации. Направления дальнейших исследований будут сосредоточены на институциональных вопросах индустриализации и диджитализации российского бизнеса в рамках корпоративных стратегий устойчивого развития.

\section{СПИСОК ИСПОЛЬЗОВАННЫХ ИСТОЧНИКОВ}

1. Müller, J. M. What Drives the Implementation of Industry 4.0? The Role of Opportunities and Challenges in the Context of Sustainability / J. M. Müller, D. Kiel, K.-I. Voigt. DOI 10.3390/su10010247 // Sustainability. - 2018. - Vol. 10, issue 1. - URL: https://www. mdpi.com/2071-1050/10/1/247 (дата обращения: 20.01.2021).

2. Impact of Industry 4.0 on Environmental Sustainability / J. Oláh, N. Aburumman, J. Popp [et al.]. - DOI 10.3390/su12114674 // Sustainability. - 2020. - Vol. 12, issue 11. URL: https://www.mdpi.com/2071-1050/12/11/4674 (дата обращения: 20.01.2021).

3. A Quality Scorecard for the Era of Industry 4.0 / W. S. Shin, J. J. Dahlgaard, S. M. Dahlgaard-Park, M. G. Kim. - DOI 10.1080/14783363.2018.1486536 // Total Quality Management \& Business Excellence. - 2018. - Vol. 29, issue 9-10. - Pp. 959-976. - URL: https:// www.tandfonline.com/doi/abs/10.1080/14783363.2018.1486536? journalCode $=$ ctqm 20 (дата обращения: 20.01.2021).

4. Салимова, Т. А. Менеджмент качества в условиях перехода к Индустрии 4.0 / Т. А. Салимова, Н. Ш. Ватолкина // Стандарты и качество. - 2018. - № 6. C. 58-62. - URL: https://ria-stk.ru/stq/adetail.php?ID=169077 (дата обращения: 20.01.2021). - Рез. англ.

5. Reflection of Digitalization on Business Values: The Results of Examining Values of People Management in a Digital Age / J. Blštáková, Z. Joniaková, N. Jankelová [et al.]. DOI 10.3390/su12125202 // Sustainability. - 2020. - Vol. 12, issue 12. - URL: https://www. mdpi.com/2071-1050/12/12/5202 (дата обращения: 20.01.2021).

6. Challenges and Driving Forces for Industry 4.0 Implementation / I. Vuksanović Herceg, V. Kuč, V. M. Mijušković, T. Herceg. - DOI 10.3390/su12104208 // Sustainability. 2020. - Vol. 12, issue 10. - URL: https://www.mdpi.com/2071-1050/12/10/4208 (дата обращения: 20.01.2021).

7. Industry 4.0 / H. Lasi, P. Fettke, H. G. Kemper [et al.]. - DOI 10.1007/s12599-0140334-4 // Business \& Information Systems Engineering. - 2014. - Vol. 6. - Pp. 239-242. URL: https://link.springer.com/article/10.1007/s12599-014-0334-4 (дата обращения: 20.01.2021).

8. Burmeister, C. Business Model Innovation for Industrie 4.0: Why the "Industrial Internet" Mandates a New Perspective on Innovation / C. Burmeister, D. Lüttgens, F. T. Piller. - DOI 10.5771/0042-059X-2016-2-124 // Die Unternehm. - 2016. - Vol. 70, issue 2. - 
Pp. 124-152. - URL: https://www.nomos-elibrary.de/10.5771/0042-059X-2016-2-124/ business-model-innovation-for-industrie-4-0-why-the-industrial-internet-mandates-a-newperspective-on-innovation-volume-70-2016-issue-2 (дата обращения: 20.01.2021).

9. Laudien, S. M. Business Model Innovation Processes of Average Market Players: A Qualitative Empirical Analysis / S. M. Laudien, B. Daxböck. - DOI 10.1111/radm.12208 // R\&D Management. - 2017. - Vol. 47, issue 3. - Pp. 420-430. - URL: https://onlinelibrary. wiley.com/doi/abs/10.1111/radm.12208 (дата обращения: 20.01.2021).

10. Формирование цифровой экономики в России: сущность, особенности, техническая нормализация, проблемы развития / А. В. Бабкин, Д. Д. Буркальцева, Д. Г. Костень, Ю. Н. Воробьев. - DOI 10.18721/JE.10301 // Научно-технические ведомости Санкт-Петербургского государственного политехнического университета. Экономические науки. - 2017. - Т. 10, № 3. - C. 9-25. - URL: https://economy.spbstu.ru/article/2017.65.1/ (дата обращения: 20.01.2021). - Рез. англ.

11. Бабкин, А. В. Цифровая экономика и ее влияние на конкурентоспособность предпринимательских структур / А. В. Бабкин, О. В. Чистякова. - DOI 10.18334/ rp.18.24.38670// Российское предпринимательство. - 2017. - Т. 18, №24.-С. 4087-4102.URL: https://creativeconomy.ru/lib/38670 (дата обращения: 20.01.2021). - Рез. англ.

12. Perspectives on the Future of Manufacturing within the Industry 4.0 Era / L. Hughes, Y. K. Dwivedi, N. P. Rana [et al.]. - DOI 10.1080/09537287.2020.1810762 // Production Planning \& Control. - 2020. - URL: https://www.tandfonline.com/doi/full/10.1080/095372 87.2020.1810762 (дата обращения: 20.01.2021).

13. Андиева, Е. Ю. Цифровая экономика будущего, Индустрия 4.0 / Е. Ю. Андиева, В. Д. Фильчакова // Прикладная математика и фундаментальная информатика. 2016. - № 3. - C. 214-218. - URL: https://www.elibrary.ru/item.asp?id=26598296 (дата обращения: 20.01.2021).

14. Паньшин Б. Цифровая экономика: особенности и тенденции развития / Б. Паньшин // Наука и инновации. - 2016. - № 3 (157). - C. 17-20. - URL: http://innosfera.by/ node/3787 (дата обращения: 20.01.2021). - Рез. англ.

15. Fatorachian, H. A Critical Investigation of Industry 4.0 in Manufacturing: Theoretical Operationalisation Framework / H. Fatorachian, H. Kazemi. - DOI 10.1080/09537287.2 018.1424960 // Production Planning \& Control. - 2018. - Vol. 29, issue 8. - Pp. 633-644. URL: $\quad$ https://www.tandfonline.com/doi/abs/10.1080/09537287.2018.1424960?journalCode=tppc20 (дата обращения: 20.01.2021).

16. How Virtualization, Decentralization and Network Building Change the Manufacturing Landscape: An Industry 4.0 Perspective / M. Brettel, N. Friederichsen, M. Keller, M. Rosenberg. - DOI 10.5281/zenodo.1336426 // International Journal of Mechanical, Industrial and Aerospace Sciences. - 2014. - Vol. 8. - Pp. 37-44. - URL: https://zenodo.org/ record/1336426\#.YHZ-qB8zaUk (дата обращения: 20.01.2021).

17. Tangible Industry 4.0: A Scenario-Based Approach to Learning for the Future of Production / S. Erol, A. Jäger, P. Hold [et al.]. - DOI 10.1016/j.procir.2016.03.162 // Procedia CIRP. - 2016. - Vol. 54. - Pp. 13-18. - URL: https://www.sciencedirect.com/science/ article/pii/S2212827116301500 (дата обращения: 20.01.2021).

18. Bonekamp, L. Consequences of Industry 4.0 on Human Labor and Work Organization / L. Bonekamp, M. Sure // Journal of Business and Media Psychology. - 2015. Vol. 6. - Pp. 33-40. - URL: https://www.semanticscholar.org/paper/Consequences-of-In- 
dustry-4.0-on-Human-Labour-and-Bonekamp-Sure/79c21635cee1aec94bc5ca44be369bb129556256\#related-papers (дата обращения: 20.01.2021).

19. Oettmeier, K. Additive Manufacturing Technology Adoption: An Empirical Analysis of General and Supply Chain-Related Determinants / K. Oettmeier, E. Hofmann. DOI 10.1007/s11573-016-0806-8 // Journal of Business Economics. - 2017. - Vol. 87. Pp. 97-124. - URL: https://link.springer.com/article/10.1007/s11573-016-0806-8 (дата обращения: 20.01.2021).

20. Пути снижения рисков при построении в России цифровой экономики. Образовательный аспект / А. И. Рудской, А. И. Боровков, П. И. Романов, О. В. Колосова. - DOI 10.31992/0869-3617-2019-28-2-9-22 // Высшее образование в России. 2019. - Т. 28, № 2. - C. 9-22. - URL: https://vovr.elpub.ru/jour/article/view/1609 (дата обращения: 20.01.2021).

21. The Mediating Effect of Employees' Involvement on the Relationship between Industry 4.0 and Operational Performance Improvement / G. Tortorella, R. Miorando, R. Caiado [et al.]. - DOI 10.1080/14783363.2018.1532789 // Total Quality Management \& Business Excellence. - 2021. - Vol. 32, issue 1-2. - Pp. 119-133. - URL: https://www. tandfonline.com/doi/full/10.1080/14783363.2018.1532789 (дата обращения: 20.01.2021).

22. Batista, N. C. Services Enabler Architecture for Smart Grid and Smart Living Services Providers under Industry 4.0 / N. C. Batista, R. Melı'cio, V. M. F. Mendes. - DOI 10.1016/j.enbuild.2017.02.039 // Energy and Buildings. - 2017. - Vol. 141. - Pp. 16-27. URL: https://www.sciencedirect.com/science/article/pii/S0378778816316358?via\%3Dihub (дата обращения: 20.01.2021).

23. Flexibility in the Brazilian Industry 4.0: Challenges and Opportunities / J. C. Contador, W. Cardoso Satyro, J. L. Contador, M. de Mesquita Spinola. - DOI: 10.1007/s40171020-00240-y // Global Journal of Flexible Systems Management. - 2020. - Vol. 21. Pp 15-31. - URL: https://link.springer.com/article/10.1007\%2Fs40171-020-00240-у (дата обращения: 20.01.2021).

24. Implementation of Industry 4.0 Concept in Companies: Empirical Evidences / V. L. Da Silva, J. L. Kovaleski, R. Negri Pagani [et al.]. - DOI 10.1080/0951192x.2019.1 699258 // International Journal of Computer Integrated Manufacturing. - 2020. - Vol. 33, issue 4. - Pp. 325-342. - URL: https://www.tandfonline.com/doi/full/10.1080/095119 2X.2019.1699258 (дата обращения: 20.01.2021).

Поступила 25.02.2020; одобрена после рецензирования 18.03.2021; принята к публикации 26.03.2021.

\section{Об авторах:}

Салимова Татьяна Анатольевна, декан экономического факультета, заведующий кафедрой управления качеством ФГБОУ ВО «МГУ им. Н. П. Огарёва» (430005, Российская Федерация, г. Саранск, ул. Большевистская, д. 68/1), доктор экономических наук, профессор, ORCID: https://orcid.org/0000-0003-4050-2702, tasalimova@yandex.ru

Бирюкова Людмила Ивановна, доцент кафедры управления качеством ФГБОУ ВО «МГУ им. Н. П. Огарёва» (430005, Российская Федерация, г. Саранск, ул. Большевистская, д. 68/1), кандидат экономических наук, ORCID: https:// orcid.org/0000-0002-5088-6909, lbirukova@yandex.ru 
Аникина Наталья Васильевна, доцент кафедры статистики, эконометрики и информационных технологий в управлении ФГБОУ ВО «МГУ им. Н. П. Огарёва» (430005, Российская Федерация, г. Саранск, ул. Большевистская, д. 68/1), кандидат педагогических наук, ORCID: https://orcid.org/0000-0001-8760-8710, anikinanb@mail.ru

\section{Заявленный вклад авторов:}

Т. А. Салимова - постановка научной проблемы; формирование научной гипотезы исследования; научное руководство; определение методологии исследования; интерпретация полученных результатов.

Л. И. Бирюкова - критический анализ результатов исследования; формулировка выводов; разработка практических рекомендаций.

Н. В. Аникина - сбор и систематизация аналитической информации; подготовка графического материала; построение эконометрической модели.

Авторы прочитали и одобрили окончательный вариант рукописи.

\section{REFERENCES}

1. Müller J.M., Kiel D., Voigt K.-I. What Drives the Implementation of Industry 4.0? The Role of Opportunities and Challenges in the Context of Sustainability. Sustainability. 2018; 10(1). (In Eng.) DOI: https://doi.org/10.3390/su10010247

2. Oláh J., Aburumman N., Popp J., Khan M.A., Haddad H., Kitukutha N. Impact of Industry 4.0 on Environmental Sustainability. Sustainability. 2020; 12(11). (In Eng.) DOI: https://doi.org/10.3390/su12114674

3. Shin W.S., Dahlgaard J.J., Dahlgaard-Park S.M., Kim M.G. A Quality Scorecard for the Era of Industry 4.0. Total Quality Management \& Business Excellence. 2018; 29(9-10):959-976. (In Eng.) DOI: https://doi.org/10.1080/14783363.2018.1486536

4. Salimova T.A., Vatolkina N.Sh. Quality Management under the Transition to the Industry 4.0. Standarty $i$ kachestvo $=$ Standards and Quality. 2018; (6):58-62. Available at: https:// ria-stk.ru/stq/adetail.php?ID=169077 (accessed 20.01.2021). (In Russ., abstract in Eng.)

5. Blštáková J., Joniaková Z., Jankelová N., Stachová K., Stacho Z. Reflection of Digitalization on Business Values: The Results of Examining Values of People Management in a Digital Age. Sustainability. 2020; 12(12). (In Eng.) DOI: https://doi.org/10.3390/su12125202

6. Vuksanović Herceg I., Kuč V., Mijušković V.M., Herceg T. Challenges and Driving Forces for Industry 4.0 Implementation. Sustainability. 2020; 12(10). (In Eng.) DOI: https:// doi.org/10.3390/su12104208

7. Lasi H., Fettke P., Kemper H.G., et al. Industry 4.0. Business \& Information Systems Engineering. 2014; 6:239-242. (In Eng.) DOI: https://doi.org/10.1007/s12599-014-0334-4

8. Burmeister C., Lüttgens D., Piller F.T. Business Model Innovation for Industrie 4.0: Why the "Industrial Internet" Mandates a New Perspective on Innovation. Die Unternehm. 2016; 70(2):124-152. (In Eng.) DOI: https://doi.org/10.5771/0042-059X-2016-2-124

9. Laudien S.M., Daxböck B. Business Model Innovation Processes of Average Market Players: A Qualitative Empirical Analysis. R\&D Management. 2017; 47(3):420-430. (In Eng.) DOI: https://doi.org/10.1111/radm.12208 
10. Babkin A.V., Burkaltseva D.D., Kosten D.G., Vorobev Yu.N. Formation of Digital Economy in Russia: Essence, Features, Technical Normalization, Development Problems. Nauchno-tekhnicheskie vedomosti Sankt-Peterburgskogo gosudarstvennogo politekhnicheskogo universiteta. Ehkonomicheskie nauki = St. Petersburg State Polytechnical University Journal. Economics. 2017; 10(3):9-25. (In Russ., abstract in Eng.) DOI: https://doi.org/10.18721/JE.10301

11. Babkin A.V., Chistyakova O.V. Digital Economy and Its Impact on the Competitiveness of Business Structures. Rossijskoe predprinimatelstvo = Russian Journal of Entrepreneurship. 2017; 18(24):4087-4102. (In Russ., abstract in Eng.) DOI: https://doi. org/10.18334/rp.18.24.38670

12. Hughes L., Dwivedi Y.K., Rana N.P., Williams M.D., Raghavan V. Perspectives on the Future of Manufacturing within the Industry 4.0 Era, Production Planning \& Control. 2020. (In Eng.) DOI: https://doi.org/10.1080/09537287.2020.1810762

13. Andieva E.Yu., Filchakova V.D. Digital Economy of the Future, Industry 4.0. Prikladnaya matematika $i$ fundamentalnaya informatika = Applied Mathematics and Fundamental Computer Science. 2016; (3):214-218. Available at: https:/www.elibrary.ru/item. asp?id=26598296 (accessed 20.01.2021). (In Russ.)

14. Panshin B. Digital Economy: Features and Development Trend. Nauka $i$ innovatsii $=$ Science and Innovations. 2016; (3):17-20. Available at: http://innosfera.by/node/3787 (accessed 20.01.2021). (In Russ., abstract in Eng.)

15. Fatorachian H., Kazemi H. A Critical Investigation of Industry 4.0 in Manufacturing: Theoretical Operationalisation Framework. Production Planning \& Control. 2018; 29(8):633-644. (In Eng.) DOI: https://doi.org/10.1080/09537287.2018.1424960

16. Brettel M., Friederichsen N., Keller M., Rosenberg M. How Virtualization, Decentralization and Network Building Change the Manufacturing Landscape: An Industry 4.0 Perspective. International Journal of Mechanical, Industrial and Aerospace Sciences. 2014; 8:37-44. (In Eng.) DOI: https://doi.org/10.5281/zenodo.1336426

17. Erol S., Jäger A., Hold P., Ott K., Sihn W. Tangible Industry 4.0: A Scenario-Based Approach to Learning for the Future of Production. Procedia CIRP. 2016; 54:13-18. (In Eng.) DOI: https://doi.org/10.1016/j.procir.2016.03.162

18. Bonekamp L., Sure M. Consequences of Industry 4.0 on Human Labor and Work Organization. Journal of Business and Media Psychology. 2015; 6:33-40. Available at: https://www.semanticscholar.org/paper/Consequences-of-Industry-4.0-on-Human-Labour-and-Bonekamp-Sure/79c21635cee1aec94bc5ca44be369bb129556256\#related-papers (accessed 20.01.2021). (In Eng.)

19. Oettmeier K., Hofmann E. Additive Manufacturing Technology Adoption: An Empirical Analysis of General and Supply Chain-Related Determinants. Journal of Business Economics. 2017; 87:97-124. (In Eng.) DOI: https://doi.org/10.1007/s11573-016-0806-8

20. Rudskoy A.I., Borovkov A.I., Romanov P.I., Kolosova O.V. Ways to Reduce Risks When Building the Digital Economy in Russia. Educational Aspect. Higher education in Russia. 2019; 28(2):9-22. (In Russ., abstract in Eng.) DOI: https://doi.org/10.31992/08693617-2019-28-2-9-22

21. Tortorella G., Miorando R., Caiado R., Nascimento D., Staudacher A.P. The Mediating Effect of Employees' Involvement on the Relationship between Industry 4.0 and Operational Performance Improvement. Total Quality Management \& Business Excellence. 2021; 32(1-2):119-133. (In Eng.) DOI: https://doi.org/10.1080/14783363.2018.1532789 
22. Batista N.C., Mel1'cio R., Mendes V.M.F. Services Enabler Architecture for Smart Grid and Smart Living Services Providers under Industry 4.0 Energy and Buildings. 2017; 141:16-27. (In Eng.) DOI: https://doi.org/10.1016/j.enbuild.2017.02.039

23. Contador J.C., Cardoso Satyro W., Contador J.L., de Mesquita Spinola M. Flexibility in the Brazilian Industry 4.0: Challenges and Opportunities Global. Journal of Flexible Systems Management. 2020; 21:15-31. (In Eng.) DOI: https://doi.org/10.1007/s40171-02000240-y

24. Da Silva V.L., Kovaleski J.K., Negri Pagani R., De Matos Silva J., Corsi A. Implementation of Industry 4.0 Concept in Companies: Empirical Evidences. International Journal of Computer Integrated Manufacturing. 2020; 33(4):325-342. (In Eng.) DOI: https://doi. org/10.1080/0951192x.2019.1699258

Submitted 25.02.2020; approved after reviewing 18.03.2021; accepted for publication 26.03.2021.

About the authors:

Tatiana A. Salimova, Dean of the Faculty of Economics, Head of the Department of Quality Management, National Research Mordovia State University (68/1 Bolshevistskaya St., Saransk 430005, Russian Federation), Dr. Sci. (Economics), Full Professor, ORCID: https://orcid.org/0000-0003-4050-2702, tasalimova@yandex.ru

Lyudmila I. Biryukova, Associate Professor, Department of Quality Management, National Research Mordovia State University (68/1 Bolshevistskaya St., Saransk 430005, Russian Federation), Cand. Sci. (Economics), ORCID: https://orcid.org/0000-0002-5088-6909, lbirukova@yandex.ru

Natalya V. Anikina, Associate Professor, Department of Statistics, Econometrics and Information Technology in Management, National Research Mordovia State University (68/1 Bolshevistskaya St., Saransk 430005, Russian Federation), Cand. Sci. (Pedagogy) ORCID: https://orcid.org/0000-0001-8760-8710, anikinanb@mail.ru

Contribution of the authors:

T. A. Salimova - statement of the research problem; construction of the scientific hypothesis of the study; academic supervision; choice of research methodology; interpretation of the results.

L. I. Biryukova - critical analysis of the results; drawing conclusions; production of practical recommendations.

N. V. Anikina - collection and systematization of analytical information; preparation of graphical materials; building an econometric model.

The authors have read and approved the final version of the manuscript. 
УДК 336.722.117.7(470+571)

DOI: $10.15507 / 2413-1407.115 .029 .202102 .355-379$

Оригинальная статья / Original article http://regionsar.ru

ISSN 2587-8549 (Print)

ISSN 2413-1407 (Online)

\section{Детерминанты кредитных рейтингов регионов России}

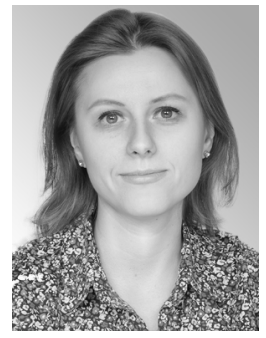

А. А. Михайлова ${ }^{1 *}$

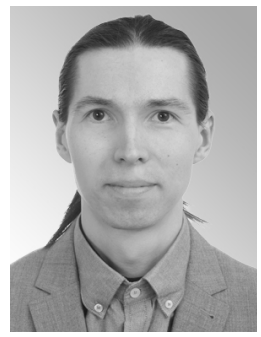

Е. Н. Тимушев ${ }^{2}$

${ }^{1}$ Институт прикладных экономических исследований ФГБОУ ВО «Российская академия народного хозяйства и государственной службы при Президенте Российской Федерацииџ (г. Москва, Российская Федераџия), *aam@irof.ru

2 Институт социиально-экономических и энергетических проблем Севера ФГБУН ФИЦ «Коми научный центр Уральского отделения Российской академии наук» (г. Сыктывкар, Российская Федерация)

Введение. Кредитный рейтинг отражает степень долговой устойчивости региона, однако вопрос о его факторах именно на региональном уровне плохо изучен в научной литературе. Цель статьи - на основе проведенного исследования определить факторы, оказавшие основное влияние при присвоении российскими и международными рейтинговыми агентствами кредитных рейтингов регионам России.

Материалы и методы. Проанализирована методология российских (АКРА и «Эксперт PA») и зарубежных (Fitch Ratings, S\&P Global Ratings и Moody's Investors Service) рейтинговых агентств. С помощью факторного и корреляционного анализа были сгруппированы факторы, к ним подобраны количественные показатели. С помощью простой и мультиномиальной логит-регрессии была проверена объясняющая сила факторов.

Результаты исследования. Подтверждено отрицательное влияние на рейтинг факторов долга, дефицита и величины госсектора и положительное - размера и динамики экономики региона. Найдено отрицательное влияние бедности и положительное ожидаемой продолжительности жизни и размера капитальных бюджетных расходов. Выявлен разный подход к показателю дотационности субъекта: для международных агентств она является незначимым фактором, но для российских - отрицательным.

Обсуждение и заключение. Установлено, что российские агентства при оценке дают приоритет количественным бюджетным, а международные - традиционным экономическим индикаторам. Особенно ценный результат заключается в обнаружении значимости показателей ожидаемой продолжительности жизни и бедности, так как

(C) Михайлова А. А., Тимушев Е. Н., 2021 Контент доступен под лицензией Creative Commons Attribution 4.0 License. This work is licensed under a Creative Commons Attribution 4.0 License. 
он свидетельствует о прямой зависимости кредитного рейтинга от качества жизни в регионе. Полученные результаты позволяют сформулировать меры региональной бюджетной политики, направленные на уменьшение кредитного риска, расширение долгового финансирования и увеличение эффективности бюджетной политики. Результаты исследования будут востребованы не только в практике госуправления, но и в дальнейших научных работах, так как открывают путь к анализу взаимосвязи кредитного рейтинга и мер контрциклической бюджетной политики, а также уточнению роли иных факторов кредитоспособности, особенно институционального характера.

Ключевые слова: долговая устойчивость, методология рейтинговых агентств, дотационность региона, факторный анализ, мультиномиальная логит-регрессия

Авторы заявляют об отсутствии конфликта интересов.

Финансирование. Статья подготовлена в рамках реализации государственного задания РАНХиГС на 2021 г.

Для цитирования: Михайлова, А. А. Детерминанты кредитных рейтингов регионов России / А. А. Михайлова, Е. Н. Тимушев. - DOI 10.15507/24131407.115.029.202102.355-379 // Регионология. - 2021. - Т. 29, № 2. - С. 355-379.

\title{
Determinants of Credit Ratings of Russia's Regions
}

\author{
A. A. Mikhaylova ${ }^{a^{*}}$, E. N. Timushev \\ a Institute for Applied Economic Research, Russian Presidential Academy \\ of National Economy and Public Administration (Moscow, Russian Federation), \\ *aam@irof.ru \\ ${ }^{b}$ Institute of Socio-Economic \& Energy Problems, Komi Science Centre of the \\ Ural Branch of the Russian Academy of Sciences (Syktyvkar, Russian Federation)
}

Introduction. A credit rating reflects the degree of debt sustainability of the region, but the issue of its factors at the regional level has been under-researched. The article is based on the conducted study and reveals the major factors that influenced the assignment of credit ratings by Russian and international rating agencies to the regions of Russia.

Materials and Methods. The methodology of both Russian (ACRA and Expert RA) and foreign (Fitch Ratings, S\&P Global Ratings, and Moody's Investors Service) rating agencies were analyzed. Factor and correlation analysis was used to group the factors; their quantitative indicators were selected. Ordinal and multinomial logistic regressions (logits) were used to test the explanatory power of the factors.

Results. The negative impact on the rating of the factors of debt, deficit, and the size of the public sector, as well as the positive impact of the size and dynamics of the region's economy has been corroborated. The negative impact of poverty, as well as the positive impact of life expectancy and the size of capital budget expenditures has been highlighted. Differences in using the indicator of the region's dependence on subsidies have been revealed: it has been regarded as an insignificant factor by international agencies, but as a negative one by Russian agencies.

Discussion and Conclusion. The authors have established that Russian agencies give priority to quantitative budget indicators, while international ones give priority to traditional economic indicators. The identified significance of the indicators of life expectancy and 
poverty has become a particularly valuable result as it indicates a direct dependence of the credit rating on the quality of life in the region. The results obtained make it possible to formulate regional budget policy measures aimed at reducing credit risk, expanding debt financing, and increasing the effectiveness of budget policy. The results of the study will be useful not only in the practice of public administration, but also in further scientific research, as they open the way to the analysis of the interdependence between the credit rating and countercyclical fiscal policy measures, as well as to clarify the role of other factors in creditworthiness, especially those of an institutional nature.

Keywords: debt sustainability, methodology of rating agencies, region's dependence on subsidies, factor analysis, multinomial logistic regression

The authors declare that there is no conflict of interest.

Funding. The article was done as part of the implementation of the government assignment to RANEPA for 2021.

For citation: Mikhaylova A.A., Timushev E.N. Determinants of Credit Ratings of Russia's Regions. Regionology = Russian Journal of Regional Studies. 2021; 29(2):355-379. DOI: https://doi.org/10.15507/2413-1407.115.029.202102.355-379

Введение. Долговая устойчивость - способность своевременного исполнения долговых обязательств - является важным условием общей бюджетной устойчивости (согласованности текущих действий государства и возможности достижения целей в будущем). Положительные эффекты долговой устойчивости - макростабильность и инклюзивность экономики [1]. Напротив, рост рисков долговой устойчивости снижает производительность труда ${ }^{1}$ и повышает вероятность финансового кризиса².

Сегодня долговая устойчивость находится под угрозой. Рост доли лиц старше трудоспособного возраста в общей численности населения и в мире, и в России вынуждает осуществлять масштабные бюджетные расходы. Текущий рост мирового долга снижает будущий потенциал заимствований. Продолжающийся коронакризис уменьшает налоговые доходы, но заставляет увеличивать расходы бюджетов.

Важным индикатором долговой устойчивости является кредитоспособность заемщика. Традиционным индикатором последней выступает кредитный рейтинг эмитента - информированное стороннее мнение о кредитоспособности (риске отказа от исполнения обязательств). Рейтингование позволяет увеличить доступность информации и, как следствие, ликвидность на долговом рынке. Суверенный рейтинг России на сегодняшний день сохраняется на весьма низком уровне (от «ВВВ-» до «ВВВ»). Это объясняется высокой ролью государства в экономике, неблагоприятными демографическими и институциональными факторами и внешнеполитической неопределенно-

\footnotetext{
${ }^{1}$ Global Economic Prospects. Slow Growth, Policy Challenges. January. World Bank, 2020.

${ }^{2}$ Debt. Use It Wisely. Fiscal Monitor Reports. IMF, 2016.
} 
стью ${ }^{3}$. При этом вопрос подходов, применяемых кредитными рейтинговыми агентствами при присвоении рейтингов на уровне регионов, а также сходства и отличия между данными подходами крайне мало изучен. Например, в обзорном труде специалистов Всемирного банка отсутствует сравнительный анализ факторов рейтинга в разрезе рейтинговых агентств [2].

По России в целом отечественный рейтинг есть лишь примерно у каждого третьего субъекта, зарубежный - лишь у каждого четвертого (рис. 1). Наибольший охват наблюдается в регионах Приволжского и Уральского федеральных округов. При этом вариация регионов по величине рейтинга велика ${ }^{4}$ и разница между оценками отечественных и зарубежных рейтинговых агентств весьма заметна (последние заметно ниже). Во многом это обусловлено «потолком» региональных рейтингов - рейтингом федеральных органов власти. Однако возможно существование и более глубоких причин. Их поможет выявить поиск детерминант рейтинга, предпринятый в данной работе.

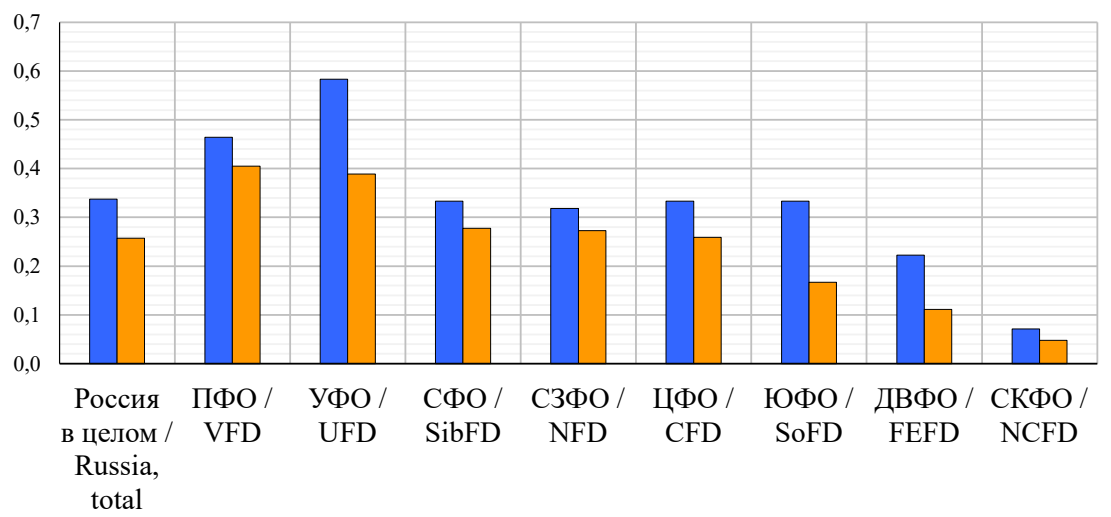

$\square$ Российские агентства / Russian agencies

$\square$ Международные агентства / International agencies

Р и с. 1. Среднее число рейтингов на единицу числа субъектов, ед. ${ }^{5}$

F i g. 1. Average number of ratings per constituent entity, units

${ }^{3}$ Fitch Affirms Russia at 'BBB-'; Positive Outlook [Электронный pecypc]. FitchRatings, 2019. February, 15. URL: https://www.fitchratings.com/site/pr/10063310 (дата обращения: 07.08.2020); Russian Federation. Summary Analysis. S\&P Global Ratings. 2019. July.

${ }^{4}$ Кредитные рейтинги каждого субъекта России не представлены в силу ограничений на объем работы.

${ }^{5}$ Рассчитано на единицу числа российских (2) и международных (3) рейтинговых агентств. Применяется обозначение федеральных округов России: ЦФО - Центральный (CFD - Central Federal District), СЗФО - Северо-Западный (NFD - Northwestern Federal District), ЮФО - Южный (SoFD - Southern Federal District), CКФО - Северо-Кавказский (NCFD - North Caucasian Federal District), ПФО - Приволжский (VFD - Volga Federal District), УФО - Уральский (UFD - Ural Federal District), СФО - Сибирский (SibFD - Siberian Federal District), ДВФО - Дальневосточный (FEFD - Far Eastern Federal District). 
Источником для рисунка 1 послужили данные, приведенные в таблице 1.

Т а б л и ц а 1. Источники данных для рисунка 1

$\mathrm{T}$ a b 1 e 1. Data sources for figure 1

\begin{tabular}{|c|c|c|}
\hline $\begin{array}{c}\text { Агентство / } \\
\text { Agency }\end{array}$ & Величина рейтинга / Rating Value & Методология / Methodology \\
\hline AKPA / ACRA & $\begin{array}{l}\text { URL: https://www.acra-ratings.ru/ratings/ } \\
\text { issuers? } \mathrm{q}=\& \text { subgroups } \% 5 \mathrm{~B} \% 5 \mathrm{D}=2 \#- \\
\text { search }\end{array}$ & $\begin{array}{l}\text { URL: https://www.acra-rat- } \\
\text { ings.ru/criteria (доступна } \\
\text { только зарегистрированным } \\
\text { пользователям) / (available } \\
\text { only to registered users) }\end{array}$ \\
\hline
\end{tabular}

«Эксперт URL: https://www.raexpert.ru/ratings/ PA»/ Expert regioncredit/

URL: https://www.raexpert. ru/docbank//19f/9a3/334/ b6700468ac19d78ea8cd08c. pdf

Fitch Ratings Не ранее января 2018 г. / January 2018 (Fitch) or later

S\&P Global Долгосрочные рейтинги регионов Ratings (S\&P) Российской Федерации / Long-term ratings of regions of the Russian Federation

Reuters. URL: https://fr.reuters.com/article/rating-idRUL8N15A371.

Рейтинги позднее января 2018 г. получены авторами посредством анализа официальных сайтов финансовых

Moody's

Investors

Service

(Moody's) ведомств регионов России и поисковых систем в интернете / Ratings later than January 2018 were obtained by the authors through an analysis of the official websites of the financial departments of Russia's regions, as well URL: https://www.fitchratings.com/site/re/10087140

URL: https://www.standardandpoors.com/en_US/web/ guest/ratings/ratings-criteria/-/ articles/criteria/governments/ filter/international-publicfinance (доступна только зарегистри рован ным пользователям) / (available only to registered users)

URL: https://www.moodys. com/ (доступна только зарегистрированным пользователям) / (available only to registered users) as through web search engines

Цель статьи - по материалам проведенного исследования определить детерминанты кредитных рейтингов, присваиваемых отечественными и международными агентствами регионам России. Для этого мы проанализировали методологию ведущих российских (АКРА и «Эксперт РА») и международных (Fitch Ratings, S\&P Global Ratings и Moody's Investors Service, далее - Fitch, S\&P и Moody's соответственно, вместе также - «большая тройка») кредитных рейтинговых агентств (табл. 1). Мы собрали большой набор показателей и для отбора наиболее важных из них применили регрессионный анализ, предварительно сузив количество показателей методами факторного и корреляционного анализа. Следует подчеркнуть, что при поиске детерминант мы строго следуем открытым методологиям агентств - соответственно, иные факторы, не отраженные в документах, остаются за пределами анализа. Так- 
же необходимо помнить ограничения рейтинга ${ }^{6}$ - он присваивается преимущественно на основе данных, которые предоставил объект оценки и/или которые доступны. Поэтому рейтинг показывает вероятность дефолта только относительно других объектов оценки (регионов), а за пределами внимания агентств остаются нераскрытые обстоятельства и трудно прогнозируемые события (например, экстренная финансовая помощь).

Актуальность проведенного нами исследования факторов (детерминант) кредитных рейтингов лежит как в теоретической, так и практической плоскости. Со стороны теории обнаружение существенных факторов обогатит понимание понятия кредитоспособности и определит, какие аспекты являются решающими с точки зрения внешнего наблюдателя-эксперта. С практической точки зрения идентификация значимых показателей укажет на аспекты бюджетной политики, улучшение которых благоприятно повлияет на кредитоспособность региона.

Обзор литературы. По вопросу подходов разных агентств к присвоению кредитного рейтинга в литературе до сих пор не сложилось единого мнения. С одной стороны, несмотря на применение схожих показателей, международные агентства используют разные подходы при их обработке и комбинации весов [3]. С другой стороны, итоговые рейтинги на инвестиционной шкале мало отличаются друг от друга ${ }^{7}$. Правда, возможны и разные подходы к рейтингованию разных объектов оценки, причем с неявным предубеждением по отношению к развивающимся экономикам [4; 5]. Последние исследования подтверждают важность рейтингов как проводников информации вне зависимости от объекта анализа и/или обязательности присвоения [6]. Неудивительно, что именно для менее развитых стран осуществляется наибольшее число исследований факторов рейтинга; впрочем, состав вскрываемых факторов почти не отличается от уже известных (в качестве примера можно привести свежие работы на основе статистики государств африканского континента [7; 8]).

Кредитные рейтинги изучаются во множестве разных аспектов, не связанных с государственными финансами или региональной повесткой, например, в теории контрактов [9] и в более широких институциональных исследованиях [10]. Интересны современные работы по влиянию рейтинга на масштаб антикризисных мер, направленных на борьбу с распространением коронавирусной инфекции COVID-19 и его последствиями (рейтинг оказывается важным фактором) [11].

Наша статья во многом похожа на публикацию О. Волковой и И. Львовой [12], однако мы анализируем субъекты России в качестве заемщиков на рынке капитала, тогда как в цитируемой работе объектом интереса авторов были российские банки. В отличие от методологии рейтингования банков, методологии рейтингования регионов, используемые как отечественными,

${ }^{6}$ IMF. Global Financial Stability Report: Sovereigns, Funding and Systemic Liquidity. 2010.

7 Там же. 
так и ведущими зарубежными агентствами, можно найти в открытом доступе (табл. 1). Это дало нам большое преимущество: при поиске детерминант рейтингов мы опираемся не только на результаты академических работ, но и на фактические руководства, применяемые специалистами кредитных агентств.

В академической литературе факторы суверенных кредитных рейтингов относительно широко изучены. Например, схожий с нашим подход - опора на методологию рейтингования - применяют в своей статье С. Ю. Чой, М. М. Чит, У. Л. Тео, которые анализируют (и подтверждают) значимость ряда статистических показателей для рейтингов федеральных правительств [13]. Напротив, детерминантам рейтингов регионов уделяется гораздо меньшее внимание. Из последних на эту тему можно выделить работы таких авторов, как Г. Лью, Р. Сунь [14], Э. Фоури, Т. Верстер, Г. У. Ван Вуурен [15], К. Ханниман [16]. Однако по своему предмету они довольно узки - рассматриваются влияние открытости экономики региона на размер заимствований, аспекты совершенствования региональной методологии и влияние на рейтинг характера межбюджетных отношений соответственно. В своей пионерской работе Р. Кантор и Ф. Пакер, анализируя факторы суверенных кредитных рейтингов от S\&P и Moody’s, выявили основные детерминанты, актуальные и сегодня, размер и динамику экономики, инфляцию, величину долга, прошлое долговое поведение [17]. Таким образом, была подтверждена гипотеза о том, что возможно существование небольшого числа основных факторов (предикторов) рейтингов из сферы традиционных социально-экономических показателей. Более того, их работа показала, что в дополнение к уже учтенному рынком риску долговых инструментов разных эмитентов спреды процентных ставок по соответствующим бумагам испытывают дополнительное (еще не учтенное рынком) влияние в силу появления новой информации на финансовом рынке в результате объявления рейтинга. Причем данный эффект наиболее силен для эмитентов, рейтинг которых находится ниже инвестиционной шкалы (эмитенты со спекулятивным рейтингом, non-investment grade).

Позднее были найдены иные экономические детерминанты кредитных рейтингов - размер и эффективность госсектора, конкурентоспособность экономики [18; 19], валюта заимствований [20], состояние банковского сектора [21], принадлежность к валютному союзу (Еврозоне) [22], а также бюджетные детерминанты - структура долга и особенности межбюджетных отношений [2], дефицит [17], доля капитальных расходов [23]. Выделяют также детерминанты географического характера [24], которые, впрочем, можно отнести к вышеупомянутым группам.

В отечественной литературе вопросы о различиях в подходах российских и международных рейтинговых агентств и факторах, играющих решающую роль при присвоении рейтинга регионам России, насколько нам известно, ранее не затрагивались. 
Материалы и методы. Поиск основных детерминант кредитных рейтингов субъектов России проводился по большим группам показателей, разделенных на показатели бюджетной сферы и экономики ${ }^{8}$. Бюджетные показатели мы разделили на (условно) качественные и количественные в соответствии с тем, как это делают рейтинговые агентства (обсуждается далее). Источником информации по бюджетным показателям стали данные Казначейства и Министерства финансов России, а также Центрального банка России в части развитости банковского кредитования в регионе. Источником большинства показателей развитости экономики региона стали данные Росстата, а для характеристики размера госсектора и диверсификации мы дополнительно использовали данные Федеральной налоговой службы (ФНС России). Для приведения величин в относительное выражение в сравнении с другими регионами мы пересчитали данные по ряду показателей к средней величине соответствующего показателя по России в целом. Были использованы годовые данные за 2018 г., в случае их отсутствия - за 2017 г.

С точки зрения эмпирического анализа, Р. Кантор и Ф. Пакер считают, что оценка значимости показателей рейтинга простым методом наименьших квадратов (МНК) хотя и довольно проста, но дает весьма достоверные результаты [17]. Причем, по их мнению, наиболее достоверные результаты дает именно линейная спецификация модели, а не, например, экспоненциальная или логарифмическая. Альтернативные техники оценки, такие как логит- или пробит-модели с небинарной зависимой переменной (мультиномиальные) также весьма часто встречаются в литературе [18; 25]. Они наиболее эффективны в случае большого числа наблюдений, например, при анализе корпоративных рейтингов. К сожалению, в случае с регионами России количество наблюдений существенно ограничено 9 . Однако важным преимуществом логит- и пробит-модели является возможность разграничить влияние факторов в разных группах объектов анализа (субъектов с разным рейтингом). Именно поэтому в данной работе мы используем оба подхода к количественному анализу.

Мы оцениваем простую аддитивную линейную модель формирования кредитного рейтинга региона (1) простым методом наименьших квадратов (МНК) и мультиномиальной логит-регрессией. Рейтинговые шкалы были переведены в целые числовые значения (мы основываемся на самых свежих данных о рейтингах). В отличие от других исследователей ${ }^{10}$ [12], мы применяем шкалу Trading Economics, когда «100» присваивается ситуации наивыс-

${ }^{8}$ Состав всех проанализированных показателей, источники данных и результаты применения факторного и корреляционного анализа не приводятся, но доступны от авторов по запросу.

9 Всего лишь 39 регионов с общим рейтингом как от российских, так и международных кредитных рейтинговых агентств, 45 - с рейтингом от международных агентств, 51 - с рейтингом от российских агентств.

${ }^{10}$ Карминский А. М. Модели корпоративных кредитных рейтингов. Препринт WP/2010/086. М.: Российская экономическая школа, 2010. 
шей кредитоспособности («ААА») (подробнее данная шкала описывается ниже по тексту). Рейтинги международных агентств были переведены в национальную шкалу ${ }^{11}$. Расчеты осуществлялись с использованием языка программирования R, версия 3.6.1.

$$
c r_{j}=a_{0}+\sum_{m=1}^{n} a_{m} * X_{m j}+\varepsilon,
$$

где $c r=\{$ cr.all, cr.rus, cr.int $\}$ - кредитный рейтинг. Для оценки МНК: рациональное число $\in[65 ; 100]$, перевод по шкале Trading Economics. Для оценки мультиномиальной логит-регрессией:

$$
c r_{j}=\left\{\begin{array}{l}
\text { "1", если [65;80], } \\
" 2 ", \text { если }(80 ; 90], \\
" 3 ", \text { если }(90 ; 100]
\end{array}\right.
$$

$X$ - вектор наиболее вероятных факторов по результатам факторного и корреляционного анализа, всего 19 показателей, первоначально включенных в регрессии.

Перед регрессионным анализом нами был проведен факторный анализ для каждой из трех групп первичных показателей, отобранных по результатам анализа методологии. Он позволил разбить каждую из трех групп на ряд подгрупп, из которых затем при помощи корреляционного анализа выбирались показатели, имевшие наиболее тесную взаимосвязь с кредитным рейтингом (crall). Показатели, не попавшие в подгруппы - с высокой уникальностью (uniqueness), - дополнительно проверялись по признаку парной корреляции с рейтингом и при высокой взаимосвязи также отбирались в регрессию.

Результаты исследования. Кредитные рейтинги имеют форму символьных обозначений. Без учета дополнений (modifiers) и специальных символов для преддефолтных состояний можно выделить девять статусов, присваиваемых эмитенту. Начиная с позиции «ВВ» (для рейтинга Moody's - с «ВBВ»), ценные бумаги обретают неформальный статус спекулятивных, т. е. бесполезных с точки зрения долгосрочного вложения средств. Методика Moody's также несколько отличается от традиционной символьной шкалы рейтингов, и иногда ее становится довольно трудно интерпретировать и сопоставлять. В рамках анализа же наиболее удобным является перевод всех символьных

${ }^{11}$ В целях сопоставимости рейтингов регионов России от российских и международных агентств, для рейтингов от Fitch, S\&P и Moody’s текущий кредитный рейтинг России («ВBВ») был приравнен к рейтингу «ААА», и региональный рейтинг пересчитывался по количеству ступеней отклонения от него. Для агенств АКРА и «Эксперт РА» текущий кредитный рейтинг России по умолчанию равен «ААА». 
шкал в количественные, например, по методике информационного портала Trading Economics ${ }^{12}$ (табл. 2).

\section{Т а б л и ц а 2. Сравнение рейтинговых шкал ${ }^{13}$}

$\mathrm{T}$ a b 1 e 2. Comparison of rating scales

\begin{tabular}{c|c|c}
\hline $\begin{array}{c}\text { TE (Trading Economics } \\
\text { Rating) }\end{array}$ & $\begin{array}{c}\text { AKPA, «Эксперт PA», } \\
\text { Fitch, S\&P / ACRA, Expert } \\
\text { RA, Fitch, S\&P }\end{array}$ & Moody’s Investors Service \\
\hline 15 & CCC & Caa2 \\
20 & CCC+** & Caa1 \\
25 & B- & B3 \\
30 & B & B2 \\
35 & B+ & B1 \\
40 & BB- & Ba3 \\
45 & BB & Ba2 \\
50 & BB+ & Ba1 \\
55 & BBB- & Baa3 \\
60 & BBB & Baa2 \\
65 & BBB + & Baa1 \\
70 & A- & A3 \\
75 & A & A2 \\
80 & A+ & A1 \\
85 & AA- & Aa3 \\
90 & AA & Aa2 \\
95 & AA+ & Aa1 \\
100 & AAA & Aaa \\
& &
\end{tabular}

По нашим оценкам, детерминанты кредитных рейтингов регионов условно можно разделить на несколько основных факторов (табл. 3). Все агентства обращают внимание на экономические и бюджетные показатели долговой устойчивости (дефицит, долг, расходы на обслуживание долга, ликвидность). Однако отечественные агентства придают повышенное внимание количественным показателям, а международные - качественным индикаторам, особенно состоянию институтов.

${ }^{12}$ Trading Economics [Электронный ресурс]. URL: https://tradingeconomics.com/russia/rating (дата обращения: 07.08.2020). Trading Economics Rating - количественный индикатор рейтинга одноименного портала, учитывающий рейтинги Fitch Ratings, S\&P Global Ratings, Moody's Investors Service, а также экономические и финансовые показатели (с равным весом 20 \%). Варьируется от 0 (дефолт) до 100 (отсутствие риска).

13 Russia - Credit Rating [Электронный pecypc] / Trading Economics. URL: https:// tradingeconomics.com/russia/rating (дата обращения: 07.08.2020). 
Т а б л и ц а 3. Структура методологии рейтинговых агентств ${ }^{14}$

$\mathrm{T}$ a b $1 \mathrm{e}$ 3. Structure of methodology of rating agencies

\begin{tabular}{|c|c|c|c|c|c|}
\hline Фактор / Factor & $\begin{array}{l}\text { AKPA / } \\
\text { ACRA }\end{array}$ & $\begin{array}{l}\text { «Эксперт } \\
\text { PA» } \\
\text { Expert RA }\end{array}$ & Fitch & S\&P & Moody's \\
\hline Экономика / Economy & + & + & + & + & + \\
\hline $\begin{array}{l}\text { Параметры бюджета / Budget } \\
\text { parameters }\end{array}$ & + & + & + & + & + \\
\hline $\begin{array}{l}\text { Институциональная сфера / } \\
\text { Institutional sphere }\end{array}$ & Hет / No & Нет / No & + & + & + \\
\hline $\begin{array}{l}\text { Стратегическое } \\
\text { планирование / Strategic } \\
\text { planning }\end{array}$ & Нет / No & + & + & Hет / No & Hет / No \\
\hline $\begin{array}{l}\text { Информационная } \\
\text { прозрачность / Information } \\
\text { transparency }\end{array}$ & Нет / No & + & + & + & + \\
\hline $\begin{array}{l}\text { Сравнительный анализ / } \\
\text { Comparative analysis }\end{array}$ & + & Нет / No & Нет / No & + & Hет / No \\
\hline
\end{tabular}

Агентства АКРА и «Эксперт РА» в сфере экономики отдают приоритет традиционным макроэкономическим показателям (табл. 4). Напротив, зарубежные агентства склонны анализировать общий социально-экономический профиль (без детализации конкретных индикаторов), характер лидирующей отрасли, правила бюджетного учета, а также учитывать прогноз развития экономики.

Т а б л и ц а 4. Экономика и иные факторы ${ }^{15}$

$\mathrm{T}$ a b $1 \mathrm{e}$ 4. Economy and other factors

\begin{tabular}{|c|c|c|c|c|c|}
\hline Фактор / Factor & $\begin{array}{l}\text { AKPA / } \\
\text { ACRA }\end{array}$ & $\begin{array}{l}\text { «Эксперт } \\
\text { PA»/ } \\
\text { Expert RA }\end{array}$ & Fitch & S\&P & Moody's \\
\hline 1 & 2 & 3 & 4 & 5 & 6 \\
\hline $\begin{array}{l}\text { ВРП на душу населения (в том } \\
\text { числе в сравнении с BBП) */ } \\
\text { GRP per capita (including in } \\
\text { comparison with GDP) * }\end{array}$ & Да / Yes & $\begin{array}{l}\text { Да**/ } \\
\text { Yes** }\end{array}$ & $\ldots$ & Да / Yes & Да / Yes \\
\hline $\begin{array}{l}\text { Темп роста ВРП * / The growth } \\
\text { rate of GRP * }\end{array}$ & - & - & - & Да / Yes & - \\
\hline Заработная плата * / Wages * & $\begin{array}{l}\text { Да***/ } \\
\text { Үes*** }\end{array}$ & - & $\ldots$ & - & - \\
\hline
\end{tabular}

\footnotetext{
${ }^{14}$ Источником для таблицы послужили данные, приведенные в таблице 1.

${ }^{15}$ Там же.
} 
Окончание табл. 4 / End of table 4

\begin{tabular}{|c|c|c|c|c|c|}
\hline 1 & 2 & 3 & 4 & 5 & 6 \\
\hline $\begin{array}{l}\text { Доля налоговых доходов от } \\
\text { госсектора * / Share of tax } \\
\text { revenue from the public sector * }\end{array}$ & Да / Yes & - & $\ldots$ & - & - \\
\hline $\begin{array}{l}\text { Доля налоговых доходов } \\
\text { от доминирующей отрасли * / } \\
\text { Share of tax revenue from the } \\
\text { dominant industry * }\end{array}$ & Да / Yes & - & $\ldots$ & - & - \\
\hline $\begin{array}{l}\text { Доля крупнейшей отрасли } \\
\text { В BPП * / Share of the largest } \\
\text { industry in GRP * }\end{array}$ & - & Да / Yes & $\ldots$ & $\ldots$ & $\ldots$ \\
\hline $\begin{array}{l}\text { Уровень безработицы * / } \\
\text { Unemployment rate * }\end{array}$ & - & Да / Yes & $\ldots$ & - & - \\
\hline $\begin{array}{l}\text { Показатели социально- } \\
\text { экономической сферы региона } \\
\text { в сравнении с национальными } \\
\text { показателями * / Indicators of } \\
\text { the socio-economic sphere of the } \\
\text { region in comparison with the } \\
\text { national indicators * }\end{array}$ & $\ldots$ & $\ldots$ & $\ldots$ & Да / Yes & $\ldots$ \\
\hline $\begin{array}{l}\text { Прогноз макроиндикаторов } \\
\text { и роста диверсификации / } \\
\text { Forecast of macroeconomic } \\
\text { indicators and growth of } \\
\text { diversification }\end{array}$ & - & - & - & - & Да / Yes \\
\hline $\begin{array}{l}\text { Прогноз бюджетных } \\
\text { параметров / Forecast of budget } \\
\text { parameters }\end{array}$ & - & - & - & - & Да / Yes \\
\hline \multicolumn{6}{|l|}{ Иные факторы / Other factors: } \\
\hline $\begin{array}{l}\text { Динамика численности } \\
\text { населения * / Population } \\
\text { dynamics * }\end{array}$ & - & Да / Yes & Да / Yes & - & Да / Yes \\
\hline $\begin{array}{l}\text { Уровень демографической } \\
\text { нагрузки * / Level of } \\
\text { demographic burden * }\end{array}$ & - & Да / Yes & Да / Yes & - & Да / Yes \\
\hline $\begin{array}{l}\text { Нормы бюджетного } \\
\text { бухгалтерского учета / } \\
\text { Budget accounting standards }\end{array}$ & - & - & Да / Yes & $\ldots$ & $\ldots$ \\
\hline
\end{tabular}

Примечания / Note: * - в данной работе подобран соответствующий количественный показатель / in this paper, the corresponding quantitative indicator has been selected; ** - также применяется показатель «Объем отгруженных товаров» / indicator "Volume of shipped goods" has also been applied; *** - осуществляется корректировка на прожиточный минимум / adjustment to the cost of living has been made; «...» - однозначное наличие или отсутствие фактора не определено, так как он не встречается в представленной формулировке, но может быть скрыт в других показателях/ группах показателей / unambiguous presence or absence of a factor has not been identified, since it does not occur in the presented formulation, but may be hidden in other indicators/groups of indicators. 
Агентства Fitch, S\&P и Moody's менее активно, чем российские AКРА и «Эксперт РА», используют количественные показатели, характеризующие бюджет региона (табл. 5). Однако все анализируемые агентства, включая зарубежные, придают довольно большое значение различным индикаторам дефицита, долга и издержкам на его обслуживание. Кроме того, во всех методиках большой вес принадлежит показателям ликвидности.

Т а б л и ц а 5. Количественные параметры бюджета ${ }^{16}$

$\mathrm{T}$ a b 1 e 5. Quantitative parameters of the budget

\begin{tabular}{c|c|c|c|c|c}
\hline Фактор / Factor & $\begin{array}{c}\text { AKРA / } \\
\text { ACRA }\end{array}$ & $\begin{array}{c}\text { «Эксперт } \\
\text { PA»/ } \\
\text { Expert RA }\end{array}$ & Fitch & S\&P & Moody's \\
\hline 1 & 2 & 3 & 4 & 5 & 6 \\
\hline
\end{tabular}

Доходы и расходы / Revenue and expenses

[Налоговые и неналоговые доходы / Доходы минус субвенции] / [Tax and non-tax revenue / Revenue minus subventions]

[Налоговые доходы, полученные от крупнейшего налогоплательщика / Налоговые доходы] / [Revenue from taxes received from the largest taxpayer / Revenue from taxes]

[Капитальные расходы / Расходы минус субвенции] / [Capital expenditure / Expenditure minus Да / Yes Да**/ subventions]

[Дотации / Безвозмездные - Да / Yes поступления] / [Subsidies / Gratuitous receipts]

Дефищит и обслуживание долга / Deficit and the debt service

[Текущие доходы ${ }^{1}$ минус текущие расходы $/$ Текущие доходы] / [Current revenue minus current expenditure / Current revenue]

[Текущие доходы минус текущие расходы / Процентные расходы] / [Current revenue minus current expenditure / Interest expense]

[Дефицит / Текущие доходы] / Да / Yes [Deficit / Current revenue]

Да / Yes _ _ - Да / Yes Да/Yes $-\quad \quad-\quad$ Да $/$ Yes

16 Там же. 
Окончание табл. 5 / End of table 5

\begin{tabular}{l|c|c|c|c|c}
\hline \multicolumn{1}{c|}{1} & 2 & 3 & 4 & 5 & 6 \\
\hline [Процентные расходы / Нало- & - & Да/Yes & - & - & - \\
говые и неналоговые доходы] / \\
[Interest expense / Тах and non-
\end{tabular}
Долг / Debt

[Долг / Текущие доходы] / Да/Yes - Да/Yes Да/Yes Да/Yes [Debt / Current revenue] [Долг / ВРП] / [Debt / GRP] Да / Yes _ - Да / Yes Ликвидность / Liquidity

[Остатки на счетах / Кратко- Да/Yes Да/Yes Да/Yes Да/Yes Да/Yes срочный долг] (и иные схожие показатели ликвидности) / [Account balances / Short-term debt] (and other similar liquidity indicators)

Примечания / Note: ${ }^{* *}$ - но без вычета субвенций / without deducting subventions; ${ }^{1}$ - за исключением доходов от продажи активов, доходов от размещения средств бюджета / with the exception of income from the sale of assets, income from the placement of budget funds; ${ }^{2}$ - расходы некапитального характера / non-capital expenditure.

Менее однозначные выводы можно сделать по отношению к использованию агентствами качественных параметров бюджета (табл. 6). Если АКРА пристально изучает состояние межбюджетных отношений, особенности планирования, характер долга и кредитную историю, то Fitch основное внимание уделяет иным аспектам - условным обязательствам, забалансовым счетам, бюджетным правилам и характеру их соблюдения. Если S\&P и Moody’s применяют небольшое количество показателей, то «Эксперт РА», по нашим оценкам, вовсе не анализирует качественные аспекты.

Т а б л и ц а 6 . Качественные параметры бюджета ${ }^{17}$ $\mathrm{T}$ a b 1 e 6. Quantitative parameters of the budget

\begin{tabular}{c|c|c|c|c|c}
\hline Фактор / Factor & $\begin{array}{c}\text { AKРA / } \\
\text { ACRA }\end{array}$ & $\begin{array}{c}\text { «Эксперт } \\
\text { PA» } \\
\text { Expert RA }\end{array}$ & Fitch & S\&P & Moody’s \\
\hline 1 & 2 & 3 & 4 & 5 & 6 \\
\hline
\end{tabular}

Развитость внутрирегионального финансового рынка и банковского сектора * / Development of the intraregional financial market and banking sector*

\section{${ }^{17}$ Там же.}


Окончание табл. 6 / End of table 6

\begin{tabular}{l|c|c|c|c|c}
\hline 1 & 2 & 3 & 4 & 5 & 6 \\
\hline $\begin{array}{l}\text { Соблюдение бюджетного зако- Да / Yes } \\
\text { нодательства / Сompliance with } \\
\text { the budget legislation }\end{array}$ & - & - & - & - \\
Соблюдение бюджетной децен- Да / Yes & - & - & - & - \\
трализации * / Compliance with \\
fiscal decentralization *
\end{tabular}

Зависимость от межбюджетных трансфертов и их стабильность (негативный фактор, особенно в случае волатильности трансфертов) * / Dependence on inter-budget transfers and their stability (a negative factor, especially in the case of transfer volatility) ${ }^{*}$

Планирование параметров бюд- Да / Yes жета / Planning budget parameters Финансирует ли долг текущие Да / Yes расходы / Does the debt finance current expenditure?

Качество кредитной истории / Да/Yes Quality of the credit history

Раскрыты ли условные обязательства / Are contingent liabilities disclosed?

Финансовое состояние бюджетных организаций, учет условных обязательств / Financial condition of budgetary organizations, accounting for contingent liabilities

Примечание / Note. * - в данной работе подобран соответствующий количественный показатель / in this paper, the corresponding quantitative indicator has been selected.

Мы постарались подобрать количественный показатель к каждому фактору, описанному в методологиях агентств. Затем в целях сокращения их числа к ним были применены факторный и корреляционный анализы. По их результатам было отобрано 11 бюджетных и 8 экономических показателей. К бюджетным показателям относятся: 1) доля банковских кредитов в ВРП; 2) внутрирегиональная бюджетная децентрализация; 3) (безвозмездные поступления / доходы всего) (дотационность субъекта); 4) долг в части банковских кредитов (доля от собственных доходов); 5) (просроченная кредиторская задолженность бюджета и учреждений субъекта / расходы); 6) (капитальные расходы бюджета / расходы минус субвенции); 7) (дотации / безвозмездные поступления); 8) (сальдо текущих доходов и текущих расходов / текущие доходы); 9) (сальдо текущих доходов и текущих расходов / расходы на обслу- 
живание долга); 10) (долг / сальдо текущих доходов и текущих расходов); 11) (долг / налоговые и неналоговые доходы). К экономическим показателям относятся: 1) ВРП на душу населения по отношению к среднему показателю по России; 2) темп роста ВРП; 3) доля налоговых доходов от отраслей госсектора (госуправление, образование, здравоохранение) (размер госсектора); 4) коэффициент вариации отраслевой структуры налоговых доходов (диверсификация экономики); 5) доля частных инвестиций в ВРП (размер частных инвестиций); 6) среднедушевые денежные доходы по отношению к средней величине по России; 7) ожидаемая продолжительность жизни по отношению к средней величине по России; 8) доля социальных выплат в доходах по отношению к средней величине по России (уровень бедности).

Анализ методологии рейтинговых агентств доказал свою важность: с опорой только на академическую литературу были бы упущены многие показатели, которые «прошли» этап факторного и корреляционного анализа: доля банковских кредитов в ВРП (размер банковского кредитования в экономике); внутрирегиональная бюджетная децентрализация; просроченная кредиторская задолженность; диверсификация экономики; ожидаемая продолжительность жизни; размер частных инвестиций; уровень бедности (доля социальных выплат в доходах).

Оценки по модели (1) с наполнением ее отобранными показателями объясняют существенную долю вариации рейтингов (табл. 7).

Результаты тестов на устойчивость полученных коэффициентов говорят о достоверности оценок:

1) велики нормированные коэффициенты детерминации, в том числе псевдо-коэффициент (McFadden) для мультиномиального логита;

2) соблюдаются основные характеристики случайных ошибок - нормальность распределения (Jarque-Bera test), гомоскедастичность (Breusch-Pagan test) и отсутствие автокорреляции (Durbin-Watson test);

3) риск эндогенного характера объясняющих переменных крайне мал, исходя из характера взаимосвязи: например, крайне маловероятно, что значение рейтинга влияет на величину долга субъекта или долю налоговых доходов от отраслей госсектора, а не наоборот.

По нашим расчетам, рейтинг формируют равное количество бюджетных и экономических показателей (по 6). Вне зависимости от конкретного кредитного агентства наиболее значимое влияние на оценку кредитоспособности оказывают дотационность субъекта (положительное влияние), величина долга, размер госсектора в регионе и уровень бедности (все - отрицательное влияние). Долг на единицу собственных доходов является единственным общим фактором для рейтингов как российских, так и мировых агентств.

Рейтинги от AКРА и «Эксперт РА» в основном формируются в ответ на значения количественных бюджетных индикаторов - дотационности, сальдо текущих доходов и расходов (аналог размера дефицита) и долга. 


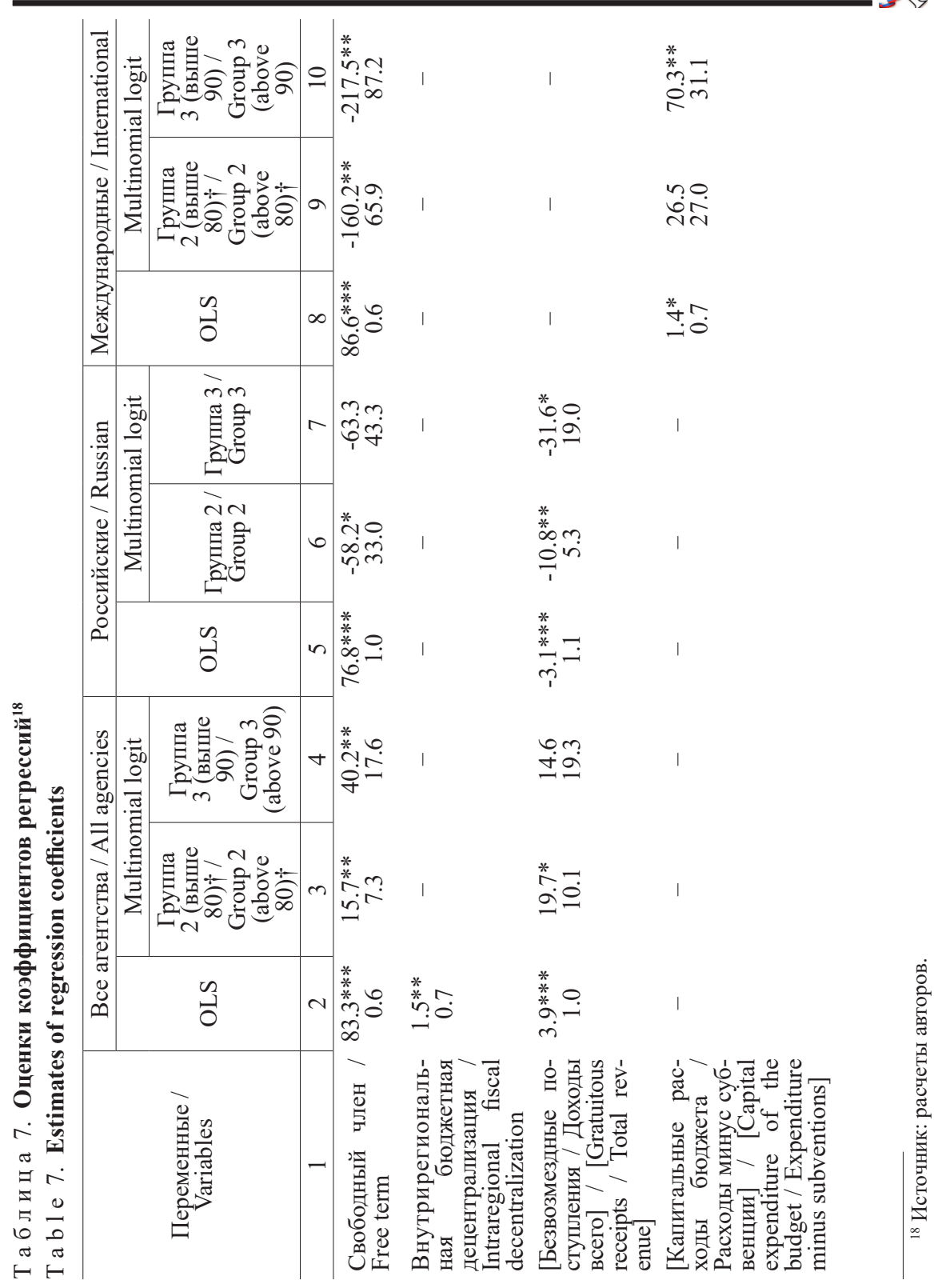




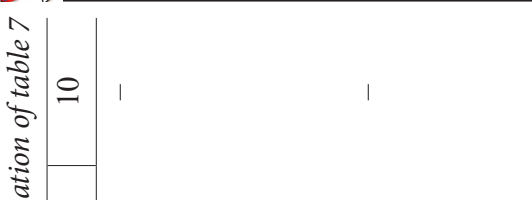

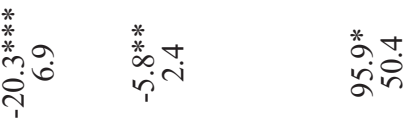

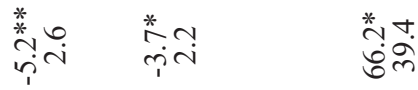

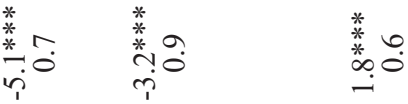

$\stackrel{*}{*} \underset{7}{*}$

भिं

$\underset{\substack{* \\ \infty}}{*} \underset{1}{*}$

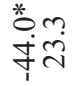

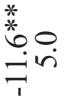

$\stackrel{*}{*} \underset{*}{*}$

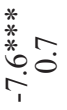

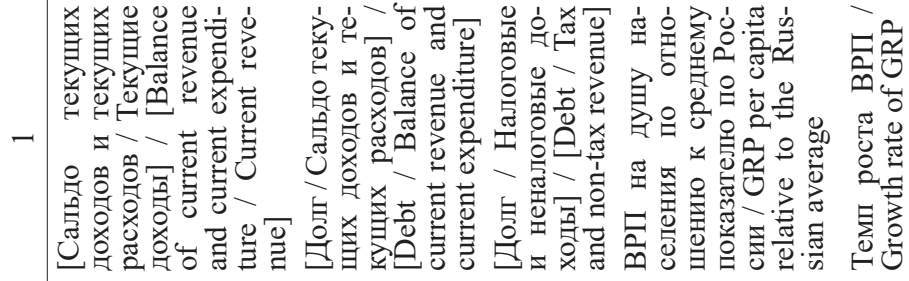




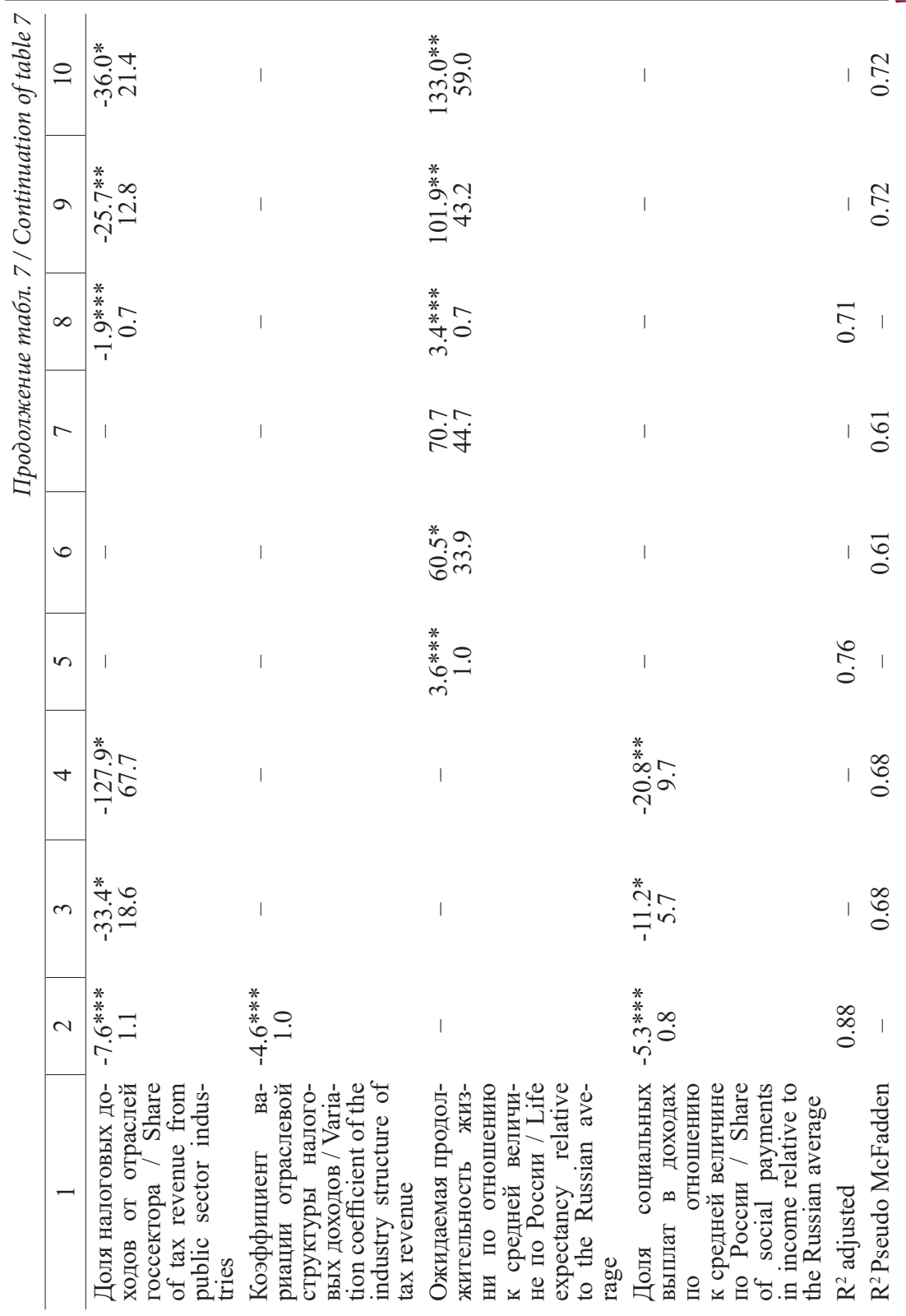




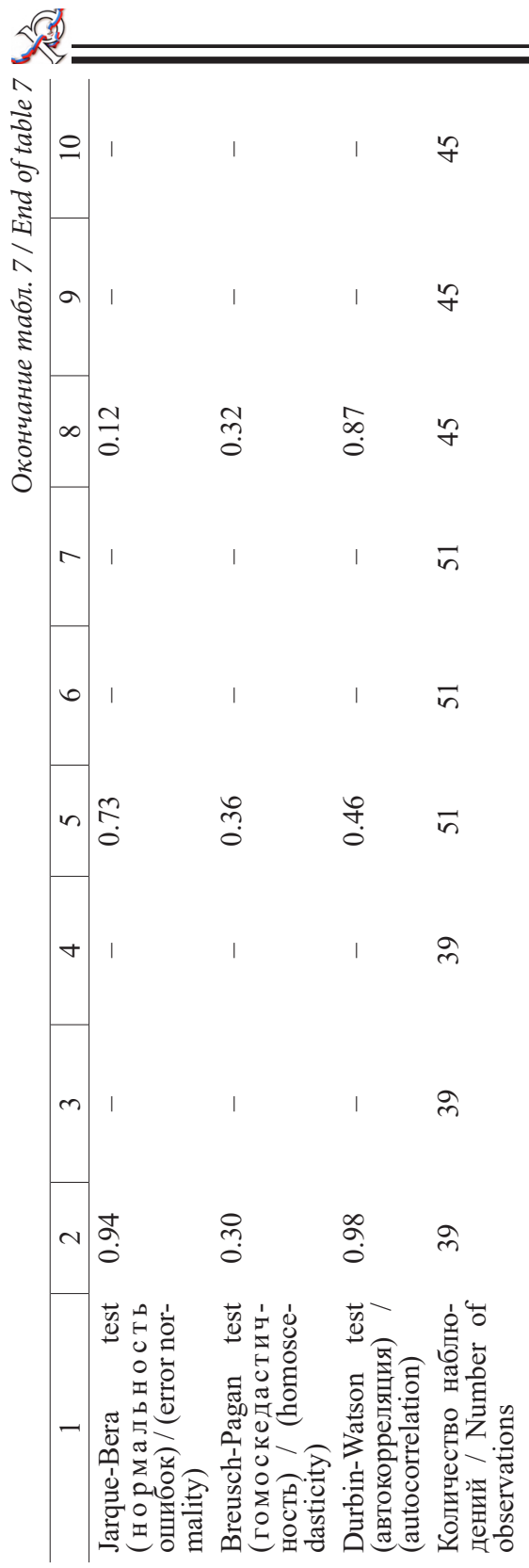

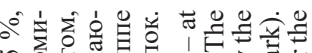

n

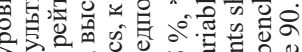

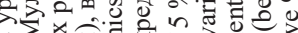

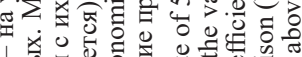

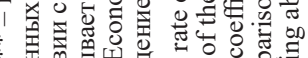

*

○

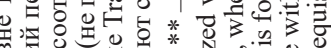

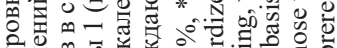

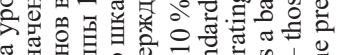

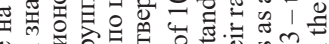

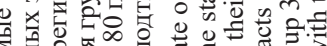

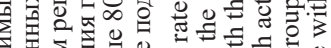

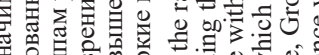

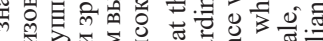

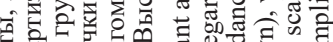

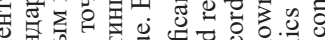

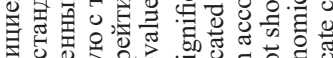

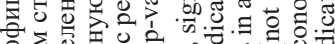

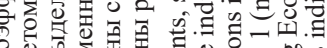

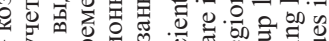

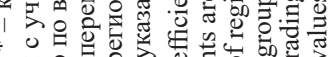

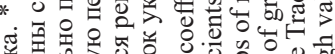

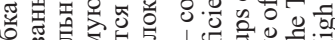

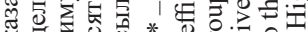

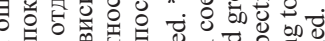

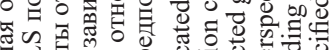

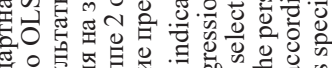

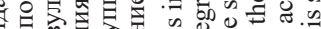

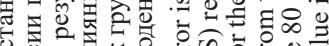

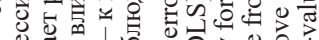

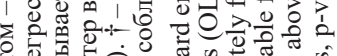

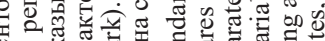
政

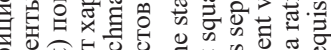

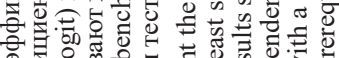

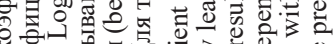

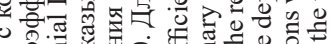
৩

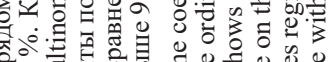

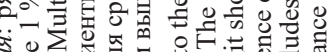

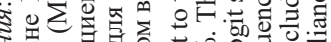

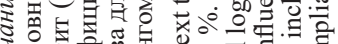

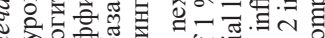

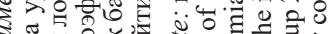

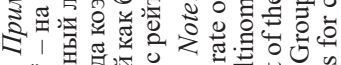

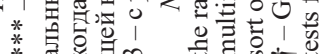


Напротив, рейтинги «большой тройки» намного сильнее зависят от экономических показателей - ВРП на душу населения по отношению к среднему показателю по России и темпа роста ВРП, размера госсектора и ожидаемой продолжительности жизни. Международные агентства также учитывают размер капитальных расходов на единицу общих расходов (но без субвенций) (положительный фактор).

Дотационность субъекта представляется наиболее интересным индикатором. Российские агентства считают долю безвозмездных поступлений в доходах (дотационность) отрицательным фактором кредитоспособности. Напротив, расчеты только по международным рейтингам не указывают на ее значимость, а для общего пула данных она способствует росту рейтинга, но только для средних оценок («А», «АА») (табл. 7). Полагаем, что «большая тройка» имеет намного бо́льшую уверенность в осуществлении дискреционной федеральной финансовой помощи в адрес менее обеспеченных бюджетов в России, чем АКРА и «Эксперт РА». Возможно, последние не рассматривают вероятность подобных событий, полагаясь только на количественные индикаторы.

Обсуждение и заключение. В рамках бюджетной политики долговой устойчивости уделяется достаточно большое внимание, так как она вносит существенный вклад в экономическое развитие. Важным способом оценки долговой и общей бюджетной устойчивости является кредитный рейтинг региона. Поэтому странно, что вопрос о факторах кредитного рейтинга на региональном уровне получает столь мало внимания в научной литературе. Известны только самые общие детерминанты - размер экономики, доходов и госсектора; величины долга и дефицита, прошлое долговое поведение.

Опираясь на доступные материалы о методологии российских (АКРА и «Эксперт РА») и зарубежных (Fitch Ratings, S\&P Global Ratings и Moody's Investors Service) кредитных рейтинговых агентств, нам удалось найти ранее не известные факторы (точнее, учитываемые только узкими специалистами) и проверить их объясняющую силу. Мы подтвердили негативное влияние на кредитоспособность размеров долга, дефицита и госсектора, выявили отрицательное влияние уровня бедности и неоднозначность дотационности субъекта. Дотационность выглядит отрицательной чертой только для российских агентств, что мы связываем с недоучетом с их стороны возможности экстренной федеральной помощи. Мы также установили, что российские и международные агентства используют разные подходы в оценке: первые отдают приоритет количественным бюджетным индикаторам, вторые - традиционным экономическим, а также ожидаемой продолжительности жизни в регионе и размеру капитальных бюджетных расходов (на единицу расходов, но без полученных субвенций).

Полученные результаты значимы как с теоретической, так и практической точек зрения, и поэтому будут полезны как академическому сообществу, так и практикующим специалистам органов государственного управления. 
Со стороны теории установление детерминант рейтингов обогащает понимание понятия кредитоспособности и проясняет его существенные признаки. Перспективными направлениями дальнейшей разработки затронутой темы представляются влияние полученного кредитного рейтинга на потенциал и проведение контрциклической бюджетной политики, а также уточнение роли иных факторов рейтингов, напрямую не связанных с бюджетными и экономическими показателями - факторов институциональной сферы, стратегического планирования и прозрачности бюджетной отчетности. С практической точки зрения, мы можем рекомендовать органам власти регионов уделить приоритетное внимание тем аспектам бюджетного процесса и экономического развития, которые наиболее тесно связаны с показателями - детерминантами кредитного рейтинга. В частности, в сфере долговой политики необходимо обеспечить безопасный (с возможностью своевременного исполнения всех обязательств) уровень долга. В политике бюджетных расходов следует рассмотреть возможность увеличения доли производительных бюджетных расходов, не ограниченных социальной сферой, а социальные расходы сконцентрировать на таких направлениях роста человеческого капитала, как здравоохранение и борьба с бедностью, причем прямая финансовая поддержка должна быть увеличена с усилением адресности социальной помощи. Капитальные бюджетные расходы должны осуществляться максимально эффективно, но отказ от них в пользу текущих расходов крайне нежелателен. Принятие данных мер будет способствовать развитию частного сектора экономики региона и повышению уровня доходов. Это может позитивно сказаться не только на уровне риска, который воспринимают фактические и потенциальные кредиторы в отношении данного региона на долговом рынке, но и непосредственно эффективности бюджетной политики.

\section{REFERENCES}

1. Bloch D., Fournier J.-M. The Deterioration of the Public Spending Mix during the Global Financial Crisis. OECD Economics Department Working Papers. 2018; (1465). (In Eng.) DOI: https://doi.org/10.1787/2f6d2e8f-en

2. Liu L., Tan K.S. Subnational Credit Ratings: A Comparative Review. World Bank Policy Research Working Papers. 2009; (5013). (In Eng.) DOI: https://doi.org/10.1596/1813-9450-5013

3. Tennant D., Tracey M. Sovereign Debt and Credit Rating Bias. Palgrave Macmillan US, 2016. Available at: https://www.researchgate.net/publication/286456424_Sovereign_ Debt_and_Credit_Rating_Bias (accessed 02.08.2020). (In Eng.)

4. Tennant D.F., Tracey M.R., King D.W. Sovereign Credit Rating: Evidence of Bias against Poor Countries. The North American Journal of Economics and Finance. 2020; (51). (In Eng.) DOI: https://doi.org/10.1016/j.najef.2018.11.006

5. Barta Z., Makszin K. The Politics of Creditworthiness: Political and Policy Commentary in Sovereign Credit Rating Reports. Journal of Public Policy. 2020. (In Eng.) DOI: https://doi.org/10.1017/S0143814X20000033 
6. Cornaggia J., Cornaggia K.J., Israelsen R.D. Credit Ratings and the Cost of Municipal Financing. The Review of Financial Studies. 2018; 31(6):2038-2079. (In Eng.) DOI: https:// doi.org/10.1093/rfs/hhx094

7. Pretorius M., Botha I. A Panel Ordered Response Model for Sovereign Credit Ratings in Africa. African Finance Journal. 2016; 18(1):20-33. Available at: https://ideas.repec. org/a/afj/journl/v18y2016i1p20-33.html (accessed 02.08.2020). (In Eng.)

8. Pretorius M., Botha I. The Determinants of Sovereign Credit Ratings in Africa: A Regional Perspective. Advances in Applied Economic Research. 2017. (In Eng.) DOI: https:// doi.org/10.1007/978-3-319-48454-9_36.

9. Parlour C.A., Rajan U. Contracting on Credit Ratings: Adding Value to Public Information. The Review of Financial Studies. 2020; 33(4):1412-1444. (In Eng.) DOI: https://doi. org/10.1093/rfs/hhz083

10. Kruck A. Resilient Blunderers: Credit Rating Fiascos and Rating Agencies' Institutionalized Status as Private Authorities. Journal of European Public Policy. 2016; 23(5):753-770. (In Eng.) DOI: https://doi.org/10.1080/13501763.2015.1127274

11. Balajee A., Tomar S., Udupa G. COVID-19, Fiscal Stimulus, and Credit Ratings. SSRN Electronic Journal. 2020. (In Eng.) DOI: https://doi.org/10.2139/ssrn.3577115

12. Volkova O., Lvova I. How Russian Banks' Financial Performance Affects Their International Ratings. Ehkonomicheskaya Politika = Economic Policy. 2016; 11(1):177-195. Available at: http://ecpolicy.ru/pdf/2016-1/volkova.pdf (accessed 02.08.2020). (In Rus., abstract in Eng.)

13. Choy S.Y., Chit M.M., Teo W.L. Sovereign Credit Ratings: Discovering Unorthodox Factors and Variables. Global Finance Journal. 2021; 48. (In Eng.) DOI: https://doi. org/10.1016/j.gfj.2020.100548

14. Liu G., Sun R. Economic Openness and Subnational Borrowing. Public Budgeting \& Finance. 2016; 36(2):45-69. (In Eng.) DOI: https://doi.org/10.1111/pbaf.12088

15. Fourie E., Verster T., Van Vuuren G.W. A Proposed Quantitative Credit-Rating Methodology for South African Provincial Departments. South African Journal of Economic and Management Sciences. 2016; 19(2):192-214. (In Eng.) DOI: https://doi.org/10.4102/ sajems.v19i2.1260

16. Hanniman K. Are Transfer-Dependent Governments More Creditworthy? Reassessing the Fiscal Federal Foundations of Subnational Default Risk. British Journal of Political Science. 2020; 50(4):1381-1403. (In Eng.) DOI: https://doi.org/10.1017/ S000712341800042X

17. Cantor R., Packer F. Determinants and Impact of Sovereign Credit Ratings. FRBNY Economic Policy Review. 1996; 2(2):37-54. Available at: https://faculty.nps.edu/relooney/3040_2.pdf (accessed 02.08.2020). (In Eng.)

18. Affonso A., Gomes P., Rother P. Short- and Long-Run Determinants of Sovereign Debt Credit Ratings. International Journal of Finance and Economics. 2011; 16(1):1-15. (In Eng.) DOI: https://doi.org/10.1002/ijfe.416

19. Chee S.W., Fah C.F., Nassir A.M. Macroeconomics Determinants of Sovereign Credit Ratings. International Business Research. 2015; 8(2):118-125. (In Eng.) DOI: https:// doi.org/10.5539/ibr.v8n2p42

20. Amstad M., Packer F., Shek J. Does Sovereign Risk in Local and Foreign Currency Differ? Journal of International Money and Finance. 2020; 101. (In Eng.) DOI: https://doi. org/10.1016/j.jimonfin.2019.102099 
21. Cuadros-Solas P.J., Salvador Muñoz C. Potential Spillovers from the Banking Sector to Sovereign Credit Ratings. Applied Economics Letters. 2020. (In Eng.) DOI: https:// doi.org/10.1080/13504851.2020.1796910

22. Stawasz-Grabowska E. Sovereign Credit Rating Determinants of the EU Countries: The Role of the Euro Area Crisis and Its Legacy. Entrepreneurial Business and Economics Review. 2020; 8(2):47-69. (In Eng.) DOI: https://doi.org/10.15678/EBER.2020.080203

23. Poghosyan T. Long-Run and Short-Run Determinants of Sovereign Bond Yields in Advanced Economies. IMF Working Papers. 2012; (271). (In Eng.) DOI: https://doi. org/10.5089/9781475529142.001

24. Botha I., Pretorius M. The Geographical and Income Differences in the Determinants of African Sovereign Credit Ratings. African Journal of Economic and Management Studies. 2020; 11(4):609-624. (In Eng.) DOI: https://doi.org/10.1108/AJEMS-08-2018-0228

25. De Moor L., Luitel P., Sercu P., Vanpee R. Subjectivity in Sovereign Credit Ratings. Journal of Banking and Finance. 2018; 88:366-392. (In Eng.) DOI: https://doi. org/10.1016/j.jbankfin.2017.12.014

Поступила 30.11.2020; одобрена после рецензирования 21.12.2020; принята к публикации 11.01.2021.

Submitted 30.11.2020; approved after reviewing 21.12.2020; accepted for publication 11.01.2021.

\section{Об авторах:}

Михайлова Анна Александровна, старший научный сотрудник Института прикладных экономических исследований ФГБОУ ВО «Российская академия народного хозяйства и государственной службы при Президенте Российской Федерации» (119571, Российская Федерация, г. Москва, Проспект Вернадского, д. 82, стр. 1), кандидат экономических наук, доцент, ORCID: https://orcid.org/0000-0003-0831-2554, Researcher ID: AAG-1958-2019, Scopus ID: 57202034126, aam@irof.ru

Тимушев Евгений Николаевич, младший научный сотрудник Института социально-экономических и энергетических проблем Севера ФГБУН ФИЦ «Коми научный центр Уральского отделения Российской академии наук» (167982, Российская Федерация, г. Сыктывкар, ул. Коммунистическая, д. 26), ORCID: https:/orcid. org/0000-0002-5220-3841, Researcher ID: U-3491-2018, Scopus ID: 57201315444, evgeny_timushev@mail.ru

Заявленный вклад авторов:

А. А. Михайлова - постановка проблемы, разработка концепции и программы исследования; научное руководство; структурирование и анализ результатов; критический анализ первичных материалов; научная доработка текста.

Е. Н. Тимушев - формирование основной концепции; анализ современной литературы; сбор данных; представление результатов и формулирование выводов; подготовка первоначального варианта текста.

Авторы прочитали и одобрили окончательный вариант рукописи. 
About the authors:

Anna A. Mikhaylova, Senior Researcher, Institute for Applied Economic Research, Russian Presidential Academy of National Economy and Public Administration (Bldg 1, 82 Vernadskogo Ave., Moscow 119571, Russian Federation), Cand. Sci. (Economics), Associate Professor, ORCID: https://orcid.org/0000-0003-0831-2554, Researcher ID: AAG-1958-2019, Scopus ID: 57202034126, aam@irof.ru

Evgeny N. Timushev, Junior Researcher, Institute of Socio-Economic \& Energy Problems, Komi Science Centre of the Ural Branch of the Russian Academy of Sciences (26 Kommunisticheskaya St., Syktyvkar 167982, Russian Federation), ORCID: https:// orcid.org/0000-0002-5220-3841, Researcher ID: U-3491-2018, Scopus ID: 57201315444, evgeny_timushev@mail.ru

Contribution of the authors:

A. A. Mikhaylova - problem statement, development of the concept and program of the research; academic supervision; structuring and analysis of the results; critical analysis of primary materials; scientific revision of the text.

E. N. Timushev - formulation of the basic concept of the study; analysis of the modern literature; data collection; evaluation of the results; drawing conclusions; preparation of the initial version of the text.

The authors have read and approved the final version of the manuscript. 


\section{Развитие крестьянских (фермерских) хозяйств как фактор стабилизации и улучшения качества жизни сельского населения}

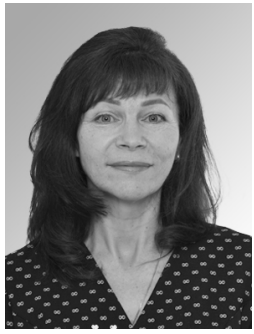

Н. Ф. Колесник

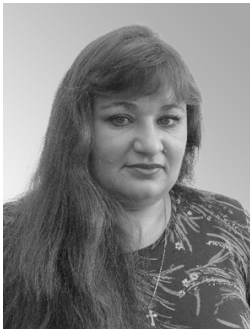

В. В. Акашева

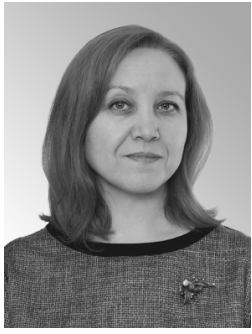

О. В. Шибилева

\section{ФГБОУ ВО «МГУ им. Н. П. Огарёва» (2. Саранск, Российская Федерация), "kolesniknf@mail.ru}

Введение. Поступательное развитие крестьянских (фермерских) хозяйств требует дальнейшего совершенствования применяемых методов государственной финансовой поддержки, необходимости полностью реализовать потенциал крестьянских (фермерских) хозяйств как наилучшего инструмента в использовании бюджетных средств, направляемых на повышение качества жизни сельского населения. Цель статьи - на основе проведенного исследования выявить ресурсы крестьянских (фермерских) хозяйств в увеличении занятости и росте доходов населения и определить систему приоритетных мер по долговременной государственной финансовой поддержке.

Материалы и методы. В ходе исследования проанализированы официальные данные Мордовиястата и Министерства сельского хозяйства и продовольствия Республики Мордовия. При обработке эмпирического материала применялись экономико-математические методы, а также методы сравнения, группировок, абсолютных разниц. Совокупность применяемых методов позволила охарактеризовать динамику и главные тенденции развития крестьянских (фермерских) хозяйств Республики Мордовия, исследовать изменения в их структуре и специализации по уровню концентрации производства и его эффективности, а также оценить взаимосвязь величины полученных грантов с объемами дополнительно полученной продукции.

Результаты исследования. Посредством анализа организационно-экономических условий функционирования крестьянских (фермерских) хозяйств Республики Мордовия дана оценка эффективности их грантовой поддержки. Обоснована необходимость увеличения государственной финансовой поддержки крестьянских (фермерских) хозяйств в виде грантов и агростартапов, способствующих росту доходов, расширению потребительского спроса и увеличению занятости сельского населения.

(C) Колесник Н. Ф., Акашева В. В., Шибилева О. В., 2021 Контент доступен под лицензией Creative Commons Attribution 4.0 License. This work is licensed under a Creative Commons Attribution 4.0 License. 
Обсуждение и заключение. Предложенные рекомендации по совершенствованию государственного регулирования будут способствовать повышению эффективности функционирования крестьянских (фермерских) хозяйств Республики Мордовия в целях повышения качества жизни сельского населения. Результаты исследования будут полезны региональным и муниципальным органами власти при разработке территориальных программ развития аграрного сектора экономики.

Ключевые слова: сельскохозяйственная организация, крестьянское (фермерское) хозяйство, личное подсобное хозяйство, стоимость продукции, доля рынка, объем продукции скотоводства, темп роста, государственное регулирование, грант

Авторы заявляют об отсутствии конфликта интересов.

Финансирование. Статья подготовлена при финансовой поддержке РФФИ (проект № 20-010-00113 А «Повышение эффективности функционирования фермерских хозяйств Республики Мордовия в условиях экономических санкций»).

Для цитирования: Колесник, Н. Ф. Развитие крестьянских (фермерских) хозяйств как фактор стабилизации и улучшения качества жизни сельского населения / Н. Ф. Колесник, В. В. Акашева, О. В. Шибилева. - DOI 10.15507/24131407.115.029.202102.380-400 // Регионология. - 2021. - Т. 29, № 2. - С. 380-400.

\title{
Development of Peasant Farm Enterprises as a Factor in Stabilizing and Improving the Quality of Life of the Rural Population
}

\author{
N. F. Kolesnik*, V. V. Akasheva, O. V. Shibileva \\ National Research Mordovia State University (Saransk, Russian Federation), \\ *kolesniknf@mail.ru
}

Introduction. The progressive development of peasant farm enterprises requires further improvement of the methods of state financial support to completely fulfil the potential of peasant farm enterprises as the best tool in using budgetary funds allocated to improve the quality of life of the rural population. This article is based on the study conducted and aims to identify the resources of peasant farm enterprises to increase employment and incomes of the population, as well as to develop a system of priority measures for long-term state financial support.

Materials and Methods. The study analyzed the official data from the territorial body of the Federal State Statistics Service in the Republic of Mordovia and the Ministry of Agriculture and Food of the Republic of Mordovia. To process the empirical material, economic and mathematical methods were used, as well as the those of comparison, groupings, and absolute differences. The set of methods used made it possible to characterize the dynamics and main trends in the development of peasant farm enterprises in the Republic of Mordovia, to study changes in their structure and specialization in terms of production concentration and efficiency, and also to assess the correlation between the amount of grants received and the volume of additional production.

Results. The analysis of the organizational and economic conditions for the functioning of peasant farm enterprises in the Republic of Mordovia made it possible to assess the effectiveness of their grant support. The necessity of broadening state financial support in the form of grants and agro-startups for peasant farm enterprises, contributing to income growth, expanding consumer demand and increasing employment of the rural population, has been substantiated. 
Discussion and Conclusion. The proposed recommendations for improving state regulation will contribute to increasing the efficiency of the functioning of peasant farm enterprises in the Republic of Mordovia in order to improve the quality of life of the rural population. The results of the study will be useful to regional and municipal authorities when establishing territorial programs for the development of the agrarian sector of the economy.

Keywords: agricultural organization, peasant farm enterprise, personal subsidiary plot, cost of production, market share, volume of livestock products, growth rate, government regulation, grant

The authors declare that there is no conflict of interest.

Funding. The article was done with the financial support from the Russian Foundation for Basic Research as part of the scientific project No. 20-010-00113 A "Increasing the efficiency of the functioning of farms in the Republic of Mordovia in the context of economic sanctions".

For citation: Kolesnik N.F., Akasheva V.V., Shibileva O.V. Development of Peasant Farm Enterprises as a Factor in Stabilizing and Improving the Quality of Life of the Rural Population. Regionology = Russian Journal of Regional Studies. 2021; 29(2):380-400. DOI: https:// doi.org/10.15507/2413-1407.115.029.202102.380-400

Введение. Важнейшими задачами современного этапа развития нашей страны являются увеличение занятости и рост доходов населения, снижение удельного веса бедных слоев, повышение качества жизни населения ${ }^{1}$.

Наиболее значимыми ресурсами в целях повышения качества жизни населения являются рост благосостояния, повышение доходов, занятости, развития социальной инфраструктуры. Большая роль в решении этих задач принадлежит крестьянским (фермерским) хозяйствам, тем самым возрастает актуальность исследования их возможностей и ресурсов в повышении доходов населения, в расширении налогооблагаемой базы местных бюджетов, в решении социальных проблем.

Для сельского населения, где доля бедных слоев продолжает оставаться самой высокой, наиболее перспективным видом бизнеса является производство сельскохозяйственной продукции с организацией крестьянского (фермерского) хозяйства. Это связано с наличием неиспользуемых земельных ресурсов, а также с тем, что для бизнеса в сфере услуг у населения нет достаточного потребительского спроса вследствие невысоких доходов. Однако и сельскохозяйственное производство вступило в новую макроэкономическую ситуацию, когда закончился длительный период постоянного дефицита продовольствия в стране и наступило время переизбыточного производства большинства продовольственных товаров. Возникающие сложности с реализацией продовольственных товаров складываются как в результате стабильно

\footnotetext{
${ }^{1}$ Послание Президента Российской Федерации Федеральному Собранию 15 января 2020 г. [Электронный ресурc]. URL: http://www.consultant.ru/document/cons_doc_LAW_342959/ (дата обращения: 30.10 .2020$)$.
} 
высоких темпов роста объемов производства в сельскохозяйственных организациях и крестьянских (фермерских) хозяйствах, так и в результате стагнации доходов населения, особенно в сельских поселениях [1].

Потребление основных продуктов питания на душу населения пока не достигло дореформенных уровней и не соответствует рекомендуемым в нашей стране медицинским нормам, особенно в малодоходных группах населения. Важнейшей первоочередной задачей остается обеспечение экономической доступности продовольствия на основе повышения доходов большинства населения. Необходимо отметить, что постоянное увеличение потребительского спроса на отечественные продовольственные и непродовольственные товары является основой для роста всей экономики, наполнения бюджетов всех уровней, повышения качества жизни населения [2].

В современный период крестьянские (фермерские) хозяйства могут и должны взять на себя функцию стабилизации и роста доходов основной массы сельского населения за счет расширения объемов производства сельскохозяйственной продукции и увеличения своей доли в получаемых от агробизнеса доходах. В крупных сельскохозяйственных организациях работает небольшая группа сельских жителей в активном трудоспособном возрасте, а основная часть получаемой прибыли поступает в распоряжение собственников и инвесторов. Для большой группы сельского населения, подростков, пенсионеров, а также работников с традиционными компетенциями, которые не смогут встроиться в предприятия нового технологического уклада, основными источниками заработка и дохода остаются работа по найму в крестьянских (фермерских) хозяйствах или формирование высокотоварного личного подсобного хозяйства [3].

В ближайший период в стране будет существенно возрастать численность слабо востребованных трудовых ресурсов в связи с повышением пенсионного возраста, со стагнацией производства и высвобождением работников в традиционных отраслях промышленности, в особенности в моногородах. На эту ситуацию сильное влияние оказывает увеличение объемов импортных товаров, которые традиционно производились в нашей стране.

Вследствие действия всех отрицательных факторов на уровень доходов населения возрастает актуальность исследования возможностей и ресурсов крестьянских (фермерских) хозяйств в увеличении занятости и росте доходов населения, решения социальных проблем и определения системы приоритетных мер по долговременной государственной финансовой поддержке. При этом необходимо определить возможности применения обширного зарубежного опыта в российских социально-экономических условиях.

Цель статьи - на основе проведенного исследования российского и зарубежного опыта разработать предложения по повышению эффективности крестьянских (фермерских) хозяйств и их государственной поддержке в целях улучшения качества жизни сельского населения. 
Обзор литературы. Научные исследования условий и эффективности функционирования фермерских хозяйств проводятся с момента их возникновения в высокоразвитых странах, в которых разнообразные фермерские хозяйства и их интеграционные объединения получили наивысшее развитие. В этих странах постоянно совершенствуются методы государственного регулирования, предлагаются новые, более эффективные, в дополнение к существующей системе, но не разрушающие ее основы. Эти проблемы исследуют, например, Н. Робсон, Р. Гассон, Б. Хилл², Т. Кизос с соавторами [4].

Необходимо отметить, что наибольшего развития фермерские хозяйства и система государственного регулирования (а также и научные исследования в этой сфере) достигли в США. В современный период рассматривается проблема сохранения мелких по масштабам сельхозпроизводства фермерских хозяйств с целью повышения доходов сельских жителей, особенно в регионах с плохой социально-экономической обстановкой для развития других видов бизнеса. Для фермерских хозяйств, работающих в сложных природно-экономических условиях, разрабатываются дополнительные инструменты повышения доходов к уже существующим долговременным мерам, которые позволяют фермерам успешно реализовывать свои бизнес-проекты. При этом предлагаются направления совершенствования кооперационных взаимосвязей и развития интеграционных объединений $[5 ; 6]$.

В исследованиях зарубежных ученых не ставится вопрос о необходимости государственной финансовой поддержки, а сельскохозяйственное производство не называют «черной дырой», в которой без видимой отдачи пропадают выделяемые средства. Финансовые ресурсы направляют фермерским хозяйствам с целью сохранения и роста доходов сельского населения, но не в виде пособий, а посредством расширения производственной деятельности. Вследствие этого разработки ученых направлены на совершенствование методов и инструментов государственной финансовой поддержки применительно к разным регионам, видам деятельности и различным хозяйствам. В каждом случае рассматривается эффективность поддержки либо на единицу полученной продукции, либо на единицу используемых ресурсов, т. е. на гектар посевной площади, на одну голову животных. Эти вопросы нашли отражение в трудах таких авторов, как Д. Коллин, Д. Лагакос, В. Во [7], С. Северини, А. Тантари [8], Л. Коуэн, Дж. Кейн, В. Райт [9] и других исследователей.

Необходимо отметить, что наиболее развитая система регулирования фермерских хозяйств работает в США, где имеется четкая цель на сохранение и рост доходов фермерских хозяйств. На достижение этой цели направлен весь комплекс применяемых методов (от прямых дотаций до контрактных закупок по гарантированным ценам). Цены рассчитываются по формулам в полном соответствии с используемым ресурсным потенциалом фермер-

${ }^{2}$ Robson N., Gasson R., Hill B. Part Time Farming Complications for farm Family Inhome // The Journal of Agricultural Economics. 1987. Vol. 38, issue 2. Pp. 167-192. 
ских хозяйств данной территории. Однако уровень этих цен не гарантирует тепличных условий: если фермер из-за своей бесхозяйственности имеет издержки выше гарантированных цен, то компенсировать убытки ему никто не будет, придется брать кредит ${ }^{3}[10]$.

В исследованиях российских ученых также нашли отражение этапы становления фермерских хозяйств в нашей стране. В первые годы рыночных преобразований главная идея состояла в том, что получившие правовой статус крестьянские (фермерские) хозяйства на основе частной собственности на землю и другие средства производства, опираясь на трудолюбие, бережливость, инициативу, предприимчивость, смогут опередить по эффективности коллективные хозяйства. Однако вместо производственных проблем возникли проблемы по формированию эквивалентных отношений с поставщиками ресурсов, перерабатывающими предприятиями, торговлей [11].

В следующем периоде наибольшее развитие получили крупные сельскохозяйственные предприятия, животноводческие комплексы, а также агрохолдинги, которые объединили производство, переработку и реализацию продовольственной продукции. Ряд ученых, например Д. Б. Эпштейн ${ }^{4}$, в своих работах стали защищать теорию устойчивости и эффективности крупных сельскохозяйственных предприятий, другие - приходили к выводу о неперспективности даже американских ферм (Б. А. Черняков ${ }^{5}$ ).

Естественно, что производственная эффективность крупных предприятий и высокомеханизированных животноводческих комплексов выше, чем мелких животноводческих форм, мелких по площади крестьянских хозяйств. Если же сопоставлять уровень технологических, экологических и экономических рисков, то приоритеты изменятся [12].

К числу актуальных проблем развития аграрного сектора относятся импортозамещение, обеспечение продовольственной независимости страны, a также экономической доступности продовольствия для малодоходных групп населения, формирование экономических условий расширенного воспроизводства и эквивалентных взаимоотношений сельского хозяйства со всеми отраслями агропромышленного комплекса. Этому посвящены работы А. Г. Папцова [10], И. Г. Ушачева, В. С. Чекалина ${ }^{6}$, Д. В. Швандар, Е. М. Фро-

${ }^{3}$ Попова О. В. Теоретические основы и методы регулирования агропромышленного производства: зарубежные модели и их адаптация к условиям России: моногр. / О. В. Попова, В. Г. Садков. М.: Изд. группа «Прогресс», 2007. 257 с.

4 Эпштейн Д. Б. Об устойчивости и эффективности крупных сельскохозяйственных предприятий // Проблемы повышения эффективности производства в агропромышленном комплексе: сб. науч. тр. СПб.; Пушкин: СЗНИЭСХ, 2003. С. 120-127.

5 Черняков Б. А. Американское фермерство: XXI век. М.: Художественная литература, 2002. 399 c.

6 Импортозамещение в АПК России: проблемы и перспективы: моногр. / И. Г. Ушачев, А. И. Алтухов, Г. В. Беспахотный и др. М.: ВНИИЭСХ, 2015. 447 с.; Ушачев И. Г., Маслова В. В., Чекалин В. С. Устойчивое развитие и повышение конкурентоспособности сельского хозяйства России в условиях углубления интеграции в ЕАЭС: моногр. М.: Научный консультант, 2019. 300 с. 
ловой, Т. Ф. Буровой [13], В. В. Милосердова ${ }^{7}$ [14], А. Н. Асаула [15] и др. Так, в исследованиях А. Г. Папцова, В. В. Милосердова, И. Г. Ушачева на первый план выдвигается анализ макроэкономической эффективности от развития каждого из трех секторов аграрной экономики и их влияние на рост доходов сельского населения и сокращение численности бедных слоев $[10 ; 14 ; 16]$.

Наиболее острой проблемой в настоящее время является сохранение и увеличение доходов сельских жителей, среди которых наиболее высокий удельный вес бедных слоев. Необходимо выделить такие исследования российских ученых, где на основе макроэкономического подхода рассматриваются и оцениваются возможности и ресурсы крестьянских (фермерских) хозяйств, личных подсобных хозяйств населения в изменении демографической ситуации на селе, прекращении оттока населения, возвращении неиспользуемых земель в сельскохозяйственный оборот. Наибольший вклад в решение этой проблемы внесли российские исследователи из научных школ, возглавляемых такими учеными, как В. Ф. Башмачников [3], В. Я. Узун [12], А. И. Алтухов [2], А. В. Чаянов ${ }^{8}$ и др. В частности, в трудах И. Н. Буздалова [17], А. В. Петрикова [18], А. П. Любимова [19] раскрывается новая макроэкономическая задача для крестьянских (фермерских) хозяйств по сохранению и росту доходов населения, по увеличению занятости, расширению количества рабочих мест, созданию более благоприятных условий для бизнеса и для работников, высвобождаемых из отраслей промышленности.

Таким образом, несмотря на широкий спектр исследований в области развития и эффективности функционирования фермерских хозяйств, представленных в отечественной и зарубежной научной литературе, имеется ряд нерешенных задач, в частности, отсутствует четкий механизм регулирования их деятельности на региональном уровне, обеспечивающий эффективное развитие фермерских хозяйств с учетом новых приоритетов в социальной сфере.

Материалы и методы. В качестве материалов исследования использовались официальные данные Росстата, Мордовиястата, ведомственная отчетность Министерства сельского хозяйства и продовольствия Республики Мордовия, а также результаты расчетов, приведенные в работах российских и зарубежных авторов. В целях совершенствования системы государственного регулирования и финансовой поддержки крестьянских (фермерских) хозяйств исследованы действующие законодательные и нормативные акты, а также практика их применения на региональном и местных уровнях, что позволило определить приоритетные направления по совершенствованию нормативной базы.

В работе применялись методы теоретических обобщений, абстрактно-логического и статистико-экономического анализа, методы группировок, цеп-

${ }^{7}$ Агропромышленный комплекс: стратегические инициативы: моногр. / В. В. Милосердов [и др.]. М.: Кадровый резерв. 2016. 630 с.

8 Чаянов А. И. Основные идеи и формы организации сельскохозяйственной кооперации: моногр. М.: Наука, 1991. 454 с. 
ных последовательных подстановок, абсолютных разниц. Для определения тенденций и перспектив развития крестьянских (фермерских) хозяйств в Республике Мордовия на основе официальных данных Территориального органа Федеральной службы государственной статистики по Республике Мордовия проведен факторный анализ изменения их доли в общей стоимости сельскохозяйственной продукции в течение пяти лет. На основе метода абсолютных разниц получена оценка объемов высвобождаемого ежегодно рынка сельскохозяйственной продукции в результате сокращения объемов продукции в личных подсобных хозяйствах населения. Анализ производства и потребления молока и мяса на душу населения показал многократное превышение производимой продукции над потреблением внутри республики, что формирует затруднения в реализации продукции для малых форм хозяйствования.

На основе аналитических группировок получена оценка влияния уровня концентрации отрасли на ее эффективность, а также исследована взаимосвязь между суммой выданных грантов и объемами полученной продукции в отобранной однородной совокупности хозяйств, занимающихся исключительно молочно-мясным скотоводством, что позволило скорректировать методику отбора хозяйств на получение грантов.

Необходимо отметить, что действующая усеченная система показателей в отчетности крестьянских (фермерских) хозяйств затрудняет анализ производственной деятельности, тем более невозможно построить значимые для органов управления экономически обоснованные статистико-математические модели, для которых необходимо собрать дополнительную информацию как минимум по 100 хозяйствам.

Результаты исследования. Регионы Российской Федерации многократно различаются по уровню бюджетной обеспеченности, налогооблагаемой базе, объемам средств, направленных в экономику, по демографической ситуации, по развитию инфраструктуры. Вследствие важности региональных условий для развития крестьянских (фермерских) хозяйств необходимо в каждом регионе проводить совместный анализ в трех секторах аграрной экономики в сельскохозяйственных организациях (СХО), крестьянских (фермерских) хозяйствах (КФХ), личных подсобных хозяйствах населения (ЛПХ). В производстве сельскохозяйственной продукции все они ориентируются на жителей региона, существующий и перспективный платежеспособный спрос, возможности и перспективы конкурентов из соседних регионов. Регионы Российской Федерации разделяются на дефицитные и профицитные по каждому виду продовольствия, что требует исследования межрегиональных поставок продукции [13]. Рассмотрим данный вопрос на примере Республики Мордовия.

В Мордовии производится молока в 1,9 раза, а мясной продукции в 3,5 раза больше, чем потребляют ее жители. Крупные сельскохозяйственные организации и агрохолдинги расширяют выпуск готовых к реализации товаров и стремятся увеличивать свою долю на рынках соседних регионов. 
Только в течение пятилетнего периода стоимость продукции в СХО в фактически действовавших ценах возросла более чем в 1,5 раза (табл. 1).

Таким образом, физический объем всей продукции ЛПХ снизился на 22,4 \%. Если бы в 2018 г. в ЛПХ произвели столько же продукции, как в 2014 г., то ее стоимость в фактически действовавших ценах составила бы 18,04 млрд руб., или на 4,04 млрд руб. больше. Это означает, что ежегодно стоимость продукции ЛПХ в фактически действовавших ценах сокращалась на 1 млрд руб., такой объем продовольственного рынка высвобождается в республике для сельхозорганизаций и крестьянских (фермерских) хозяйств (а это почти полностью касается двух видов продукции - молока и мяса).

Необходимо отметить, что по востребованности продукции главной отраслью в республике является молочно-мясное скотоводство, для развития которого в крестьянских (фермерских) хозяйствах создана хорошая ресурсная база. В них содержится 9,0 \% от всего поголовья крупного рогатого скота, в том числе $10,6 \%$ от всего поголовья коров.

В анализируемом периоде в республике происходили разнонаправленные изменения в эффективности молочно-мясного скотоводства в трех основных секторах аграрной экономики (табл. 2).

В сельскохозяйственных организациях объем производства молока увеличился на 20,4 \%, а их доля в общем объеме возросла с 69,1 до 78,2 \%. В крестьянских (фермерских) хозяйствах производство молока возросло на 37,3 \%, а их доля увеличилась с 5,7 до 7,4 \%. В этот же период доля личных подсобных хозяйств населения снизилась с 25,2 до $14,4 \%$, а объемы производства уменьшились на 40,0 \%.

В выращивании скота и птицы на мясо аналогичная тенденция: доля ЛПХ снизилась с 11,8 до 3,7 \%, а доля КФХ возросла с 0,9 до 1,3 \%. Доля сельскохозяйственных организаций в производстве мяса возросла с 87,3 до 95,2 \%, что связано с рекордными темпами роста объемов мяса птицы (в 1,7 раза), а также высокими темпами роста объемов производства свинины (в 1,3 раза) при уменьшении производства говядины на 18,5 \%. Эта ситуация является благоприятной для крестьянских (фермерских) хозяйств, занимающихся выращиванием крупного рогатого скота на мясо.

В результате перераспределения объемов производства продукции очень существенно для КФХ расширяется рынок сбыта своей продукции, в основном это касается реализации молока и говядины. Следовательно, необходимо проанализировать возможности тех крестьянских (фермерских) хозяйств, которые занимаются разведением крупного рогатого скота.

В 2020 г. в республике функционируют 203 КФХ, занимающиеся разведением крупного рогатого скота. 70 из них содержат мясных коров, предназначенных только для получения мяса, в 9 хозяйствах - смешанное производство, где содержатся и мясные, и молочно-мясные породы коров, предназначенные для одновременного получения молока и мясной продукции. 


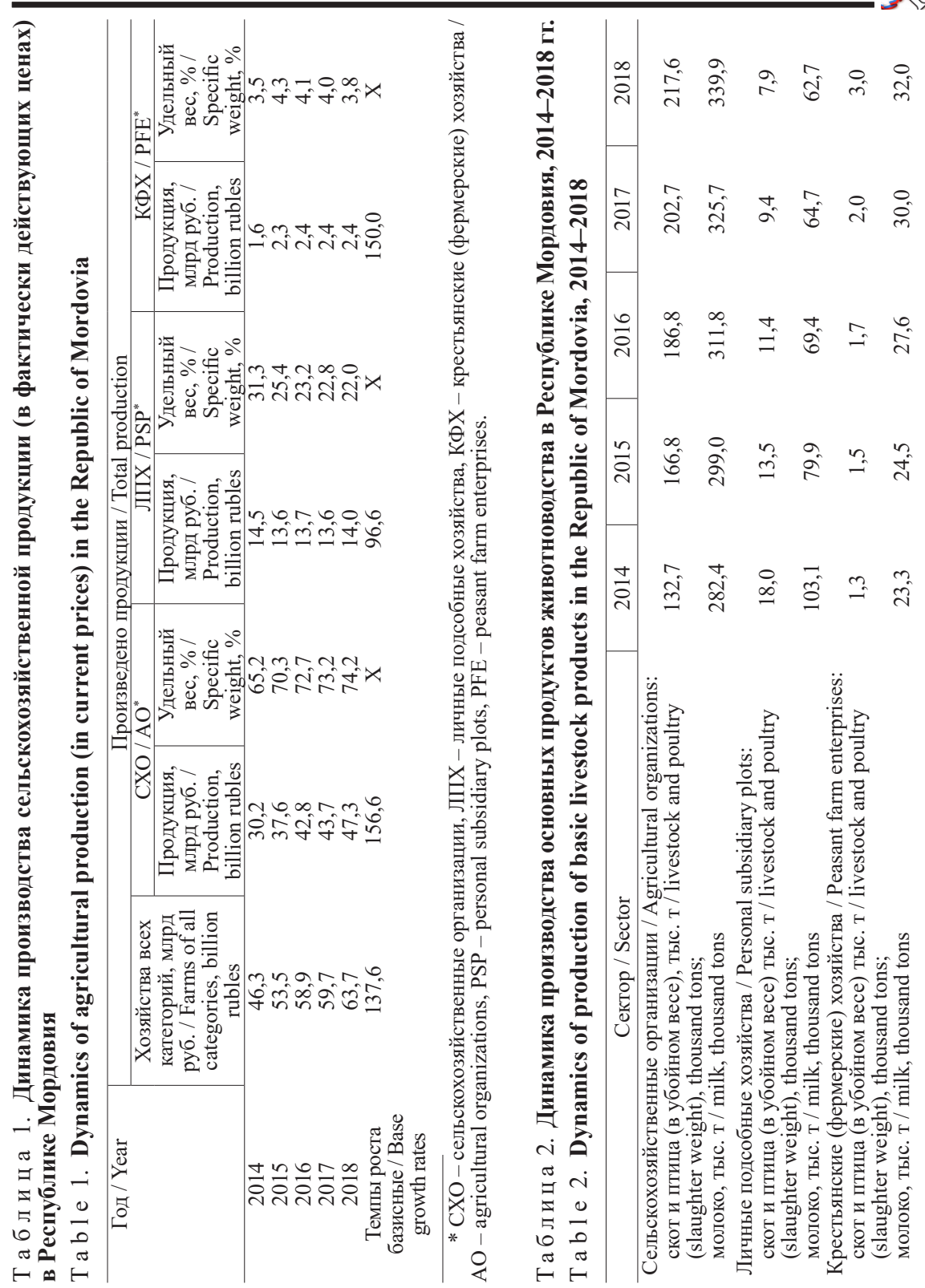


Разведением исключительно традиционных молочно-мясных пород занимаются в 124 КФХ, которые образуют одну типичную группу для углубленного анализа в целях определения возможностей и ресурсов малого бизнеса по сохранению и росту доходов сельского населения.

Одной из важных задач в анализе эффективности сельскохозяйственного производства является оценка влияния концентрации отрасли на результативные показатели, выявление наиболее перспективных производственных типов хозяйств по сочетанию отраслей и их размерам. Уровень концентрации по общему поголовью крупного рогатого скота показывает улучшение основных показателей от первой группы к восьмой. Так, продуктивность коров возросла с 3,85 до 6,13 т молока на одну корову (табл. 3).

С ростом концентрации скотоводства возрастает продуктивность коров и выход мясной продукции на одну голову общего поголовья крупного рогатого скота, увеличивается выход продукции с единицы посевной площади. Наиболее крупные хозяйства стали репродукторами молодняка животных, реализуют его на доращивание населению и другим КФХ. Крупные хозяйства становятся ресурсной базой для расширенного воспроизводства в скотоводстве, они способны обеспечивать молодняком животных другие хозяйства и, что очень важно, могут реализовывать излишки кормов 9 .

На наш взгляд, не оправдались два тезиса: это первоначальный тезис при реформировании аграрного сектора о преимуществах небольших семейных ферм перед крупными коллективными хозяйствами и подход о преимуществах укрупнения, а в итоге гигантомании в строительстве крупнейших животноводческих комплексов. Каждая из форм организации производства имеет свои преимущества и недостатки. Задача повышения эффективности сельскохозяйственного производства состоит в нахождении оптимальных размеров отраслей, а самое главное - в нахождении их оптимального сочетания и формировании производственных типов хозяйств определенной специализации и уровня концентрации основных, дополнительных и вспомогательных отраслей [14].

Необходимо отметить, что повышение концентрации скотоводства, увеличение поголовья животных, их продуктивности, объемов продукции тесно взаимосвязано с грантовой поддержкой крестьянских (фермерских) хозяйств в республике, которая начала активно реализовываться с 2012 г. За этот период КФХ получили 89 грантов на общую сумму 418,3 млн руб., которые и привели к росту объемов продукции скотоводства. Для оценки взаимосвязи количества полученных грантов, их размера в среднем на хозяйство, необходимо исключить две крайние малочисленные группы, полученные гранты которых по размерам не соответствуют принятой методике их распределения, поскольку отражают только специфические условия их получения (табл. 3).

${ }^{9}$ Агропромышленный комплекс: стратегические инициативы: моногр. / В. В. Милосердов [и др.]. М.: Кадровый резерв. 2016. 630 с. 
При оценке взаимосвязей от второй группы к седьмой отчетливо видна прямолинейная взаимосвязь средней суммы гранта на хозяйство с поголовьем скота, в том числе с поголовьем коров, и с объемом получаемой продукции. Поэтому важнейшей задачей является совершенствование системы регулирования грантовой поддержки, чтобы повышать отдачу от вложенных средств.

За период с 2012 по 2019 г. гранты получили и продолжают работу 89 крестьянских (фермерских) хозяйств, которые занимаются разведением крупного рогатого скота молочно-мясных пород для получения молока и откорма молодняка на мясо. Размеры полученных грантов различаются значительно - от 0,5 млн руб. до 37,0 млн руб. Это представляет затруднение при образовании интервалов, но выход существует при формировании интервалов с разрывом (табл. 4).

При оценке эффективности грантовой поддержки необходимо отметить снижение отдачи с возрастанием суммы гранта. Это отчетливо проявляется при сравнении четырех верхних групп, получивших гранты от 7,0 до 37,0 млн руб., куда относятся 20 КФХ. Вместе они получили 74,0 \% от всей суммы выделенных грантов, но ими произведено только $60,0 \%$ от объема молока, $52,1 \%$ от мясной продукции и лишь 25,3 \% от объема полученного зерна. В них содержится 47,0 \% от всего поголовья крупного рогатого скота и столько же от всего поголовья коров.

Наиболее крупные гранты выделены, как правило, для самых крупных хозяйств, однако соотношение размеров грантов и достигнутых результатов нарушено. В среднем на одно хозяйство в этой совокупности из двадцати хозяйств получено молока и мяса в пять раз больше, зерна - в 1,2 раза больше, поголовье коров и общее поголовье - в три раза выше, а средний размер гранта выше уже в 9,8 раза. Необходимо отметить, что крупные суммы грантов не привели к пропорциональному росту объемов продукции, чем несколько мелких грантов на эту же сумму. В то же время мелкое товарное производство на слабо регулируемом рынке имеет повышенную рискованность. Отдельные хозяйства разоряются, а другие получают прибыль в большей степени за счет резкого изменения конъюнктуры рынка, и в меньшей - за счет эффективного хозяйствования. В этой связи следует отметить, что необходимо усовершенствовать методику начисления баллов претендентам на гранты, чтобы сократить влияние субъективного фактора на возможности получения, а также на суммы грантовой поддержки.

Обсуждение и заключение. В ходе исследования было установлено, что в решении большого количества сложных макроэкономических задач значительная роль принадлежит крестьянским (фермерским) хозяйствам, так как они предоставляют возможности для трудоустройства высвобождаемых из других отраслей работников с традиционными компетенциями, создают рабочие места для маломобильных групп сельского населения, что приводит к повышению доходов и сокращению численности и удельного веса бедных слоев. 


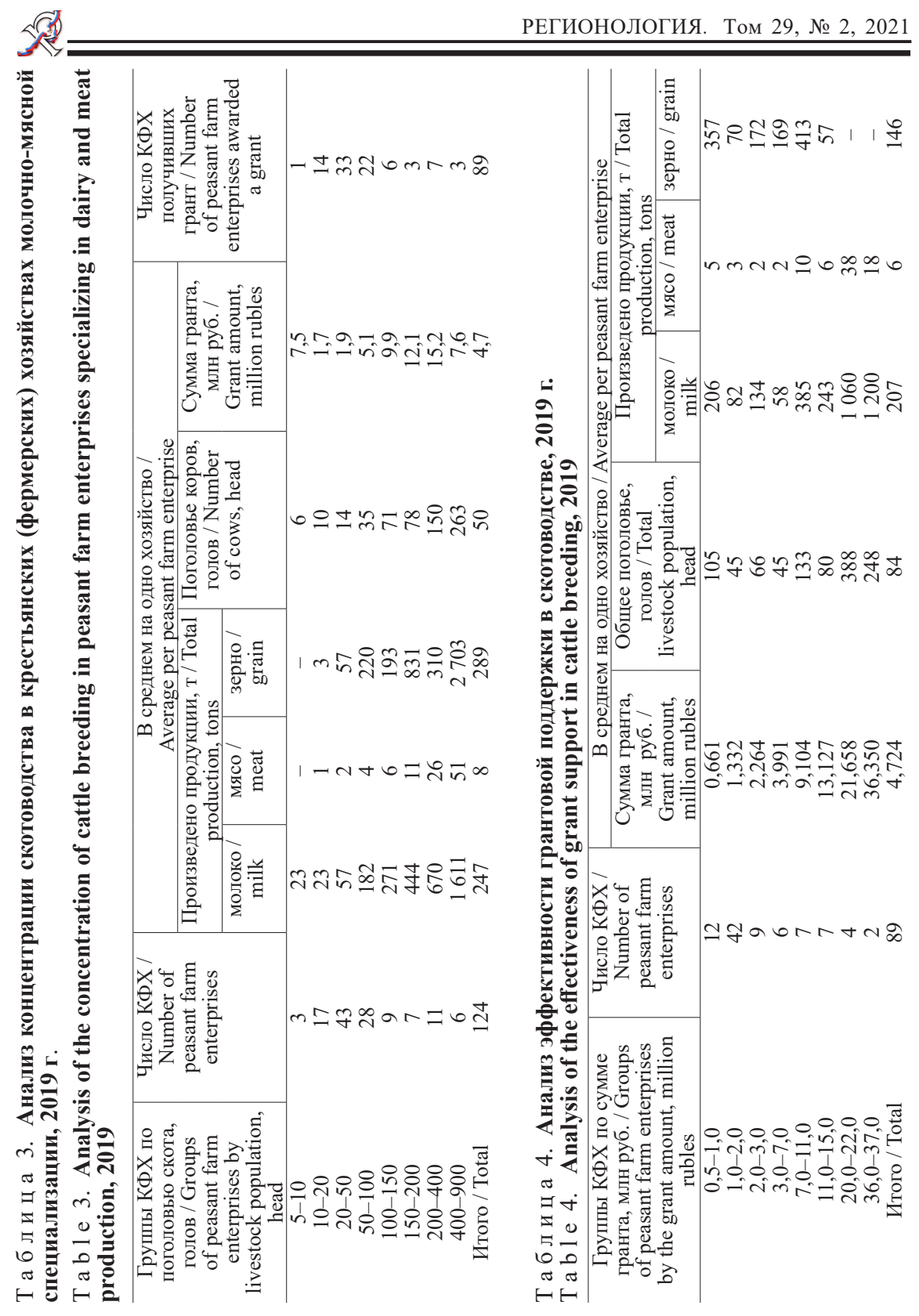


Необходимо отметить, что увеличение числа хозяйств и объемов производства расширяет потребительский спрос на производственные ресурсы, вырабатываемые на отечественных предприятиях, в то время как на крупных животноводческих комплексах оборудование, запчасти, корма покупаются за валюту в других государствах. Таким образом, крестьянские (фермерские) хозяйства способствуют увеличению доходов работников многих отраслей и поэтому являются драйвером развития всей экономики. Вследствие этих причин вложения бюджетных средств в развитие крестьянских (фермерских) хозяйств приносят несопоставимый с другими сферами колоссальный экономический и социальный эффект, этот процесс имеет совершенно другую главную цель, чем увеличение объемов сельскохозяйственной продукции.

В качестве рекомендации по совершенствованию финансовой поддержки и в целях повышения отдачи от выделяемых грантов для крестьянских (фермерских) хозяйств, занимающихся скотоводством, предлагается скорректировать методики отбора кандидатов. Необходимо стремиться к увеличению количества грантов, а не к увеличению размера гранта, так как меньшие суммы более эффективно используются. Кроме того, это позволяет вовлекать в активную деятельность большее количество населения и способствовать росту их доходов. Увеличение государственной финансовой поддержки, в том числе в виде грантов, приведет к образованию новых крестьянских (фермерских) хозяйств, увеличению объемов производимой продукции, укреплению налогооблагаемой базы местных бюджетов и расширению потребительского спроса на отечественное продовольствие.

В заключение хотелось бы остановиться на следующих моментах. В современный период развития нашей страны сокращается необходимость в переливе трудовых ресурсов из села в город, так как происходит стагнация в традиционных отраслях промышленности, которую усиливает расширяющийся импорт самых простых товаров. Начинают ускоренно развиваться предприятия нового технологического уклада с небольшой численностью работников, имеющих традиционные компетенции, но требующие сотрудников высокой квалификации в цифровой экономике.

Важная макроэкономическая задача состоит в том, где использовать высвобождаемых работников старшего поколения, за счет чего обеспечивать сохранение их доходов. В перспективе увеличится количество высвобождаемых работников в связи с повышением пенсионного возраста, соответственно, усилится движение трудовых ресурсов из города в село.

В сельских поселениях наиболее перспективным видом является аграрный бизнес из-за постоянной востребованности продовольствия, но необходимо подчеркнуть, что полностью обеспечить потребности населения могут крупные сельскохозяйственные организации и агрохолдинги. При современных технологиях они способны без фермерских хозяйств решить первую задачу продовольственной безопасности, т. е. обеспечить физическую 
доступность продовольствия. При этом остается нерешенной вторая задача продовольственной безопасности по обеспечению экономической доступности продовольствия - такого соотношения между ценами на продовольствие и доходами граждан, которое позволяет низкодоходным группам населения потреблять продукты не ниже рекомендуемых медицинских норм.

В стране складывается новая экономическая ситуация, совершенно незнакомая в предыдущие десятилетия, так как произошло превышение производства мясной и молочной продукции над потребительским спросом вследствие стагнации доходов основной массы населения. Значительная часть населения потребляет недостаточное количество продуктов не вследствие отсутствия их в шаговой доступности, а из-за низкого уровня доходов.

Экономическая ситуация в стране побуждает производителей колбасных изделий разбавлять в сложной пропорции дорогое мясо более дешевой соей и другими наполнителями. Это позволяет снизить цену реализации и получить конкурентное преимущество по сравнению с чисто мясной продукцией. Вторым приемом является удлинение сроков реализации за счет более глубокой консервации. Точно такая же ситуация в производстве молочной продукции, когда вместо натурального молочного жира применяются различные заменители.

Крестьянские (фермерские) хозяйства в состоянии производить высококачественную и экологически чистую продукцию, но они не смогут долго продавать ее по тем низким ценам, которых требует большинство покупателей. Однако потребители молочной продукции плохо представляют, что уже более полувека действует четкая экономическая пропорция или соотношение между ценой тонны дизельного топлива и ценой тонны получаемого сырого молока. Наиболее сильное влияние на издержки крестьянских (фермерских) хозяйств оказывают цены на другие производственные ресурсы, на газ, электроэнергию и т. д. При этом главным направлением государственной поддержки является выделение льгот на закупку этих ресурсов, цены на которые регулируются государственными органами. Уровень цен, как правило, зависит от цены ресурсов, а не от трудолюбия и бережливости крестьян.

Дальнейшее эффективное развитие всех сельскохозяйственных товаропроизводителей, перерабатывающих предприятий зависит от расширения потребительского спроса, так как в настоящее время продовольственные рынки наполнены, а доходы основной массы населения не растут. Главной проблемой для мелкого производства, тем более в условиях товарного насыщения, является сбыт всей продукции по ценам, обеспечивающим минимально необходимую рентабельность. Самостоятельно решать эту проблему могут не крестьянские (фермерские) хозяйства, а только их кооперативные объединения или государственные продовольственные корпорации. Этот вопрос является стержнем для решения многих макроэкономических проблем и требует своего решения. Первоочередной задачей агростартапов должно являться 
увеличение числа рачительных тружеников и опытных предпринимателей, не только прошедших теоретическую подготовку, но и закаленных суровым российским опытом. Они являются кадровым резервом при формировании кооперативных объединений и интеграционных образований, создаваемых крестьянскими (фермерскими) хозяйствами. В этом отличие агростартапов от научных стартапов, задача которых - выявление прорывных технологий, и при этом продолжают развиваться три стартапа из десяти, а семь закрываются. Кроме того, благосостояние фермеров-производителей зависит от технической оснащенности хозяйств. Другими словами, улучшение благосостояния повышает техническую эффективность, а более высокий показатель технической эффективности приводит к улучшению благосостояния. Поэтому следует усилить политику субсидирования фермерских хозяйств [20].

В этих целях необходимо продолжать разработку механизмов государственной поддержки при формировании кооперативных объединений крестьянских (фермерских) хозяйств различного профиля и направления, но самое главное - по закупке продукции хозяйств, которые обеспечат и гарантированный сбыт, и минимально необходимый уровень доходности. При этом следует сосредоточить все бюджетные средства, направленные на поддержку крестьянских (фермерских) хозяйств, в одном инструменте - в расчете экономически обоснованных цен закупки и объемах закупаемой сельскохозяйственной продукции.

Для успешного решения главных задач государственной социальной политики по повышению качества жизни населения необходимо полностью использовать потенциал крестьянских (фермерских) хозяйств, но для этого административным путем следует сформировать кооперативные объединения с государственным участием, которые станут основой для взаимоотношений государства и крестьянских (фермерских) хозяйств и распределителями бюджетных средств. Если опираться на опыт зарубежных стран, где кооперативы сформировались самостоятельно, в том числе кооперативные банки («Райфайзенбанк»), то пройдет несколько десятилетий, а проблемы бедности надо решать уже сегодня. Для сокращения бедных слоев населения более эффективно направлять бюджетные средства в стабилизацию доходов крестьянских (фермерских) хозяйств, а в меньших объемах - на оказание продовольственной помощи малоимущим слоям населения, хотя, как показало исследование, в высокоразвитых странах финансовые средства распределяются в равных долях.

Практическая значимость исследования определяется возможностью использования рекомендаций по совершенствованию механизма финансовой поддержки крестьянских (фермерских) хозяйств, способствующих их дальнейшему развитию и улучшению качества жизни сельского населения. Результаты исследования могут быть использованы региональными и муниципальными органами власти при разработке стратегии и программ 
развития крестьянских (фермерских) хозяйств региона с целью повышения их эффективности. В перспективе исследования по данной тематике будут направлены на решение социальных проблем сельского населения Республики Мордовия.

\section{СПИСОК ИСПОЛЬЗОВАННЫХ ИСТОЧНИКОВ}

1. Зинченко, А. П. Хозяйства населения по итогам Всероссийских сельскохозяйственных переписей / А. П. Зинченко. - DOI 10.34677/0021-342x-2019-2-119-128 // Известия Тимирязевской сельскохозяйственной академии. - 2019. - № 2. - С. 119-128. URL: http:/elib.timacad.ru/dl/full/09-2019-2.pdf/info (дата обращения: 27.10.2020). Рез. англ.

2. Алтухов, А. И. Совершенствование организационно-экономического механизма устойчивого развития агропромышленного производства / А. И. Алтухов // Экономика сельскохозяйственных и перерабатывающих предприятий. - 2016 - № 7. - С. 2-11. URL: http://www.eshpp.ru/abstract/2016-07_abst.htm (дата обращения: 27.10.2020). Рез. англ.

3. Башмачников, В. Ф. Вовлечение крестьянских хозяйств в решение задач импортозамещения / В. Ф. Башмачников, В. В. Дрокин, А. С. Журавлев. - DOI 10.17059/2018-2-26 // Экономика региона. - 2018. - Т. 14, вып. 2. - С. 663-675. - URL: https://economyofregion. ru/arhiv/vovlechenie-krestyanskih-hozyajstv-v-reshenie-zadach-importozameshheniya/ (дата обращения: 27.10.2020). - Рез. англ.

4. Survival Strategies of Farm Households and Multifunctional Farms in Greece // T. Kizos, J. I. Marin-Guirao, M.-E. Georgiadi [et al.]. - DOI 10.1111/j.1475-4959.2011.00403.x // Geographical Journal. - 2011. - Vol. 177, issue 4. - Pp. 335-346. - URL: https://rgs-ibg.onlinelibrary.wiley.com/doi/full/10.1111/j.1475-4959.2011.00403.x (дата обращения: 27.10.2020).

5. Young, A. Inequality, the Urban-Rural Gap and Migration/A. Young. - DOI 10.1093/qje/ qjt025 // The Quarterly Journal of Economics. - 2013. - Vol. 128, issue 4. - Pp. 1727-1789. URL: https:/academic.oup.com/qje/article-abstract/128/4/1727/1850694?redirectedFrom=fulltext (дата обращения: 27.10.2020).

6. Agricultural Decisions after Relaxing Credit and Risk Constraints / D. Karlan, R. Osei, I. Osei-Akoto, C. Udry. - DOI 10.1093/qje/qju002 // The Quarterly Journal of Economics. 2014. - Vol. 129, issue 2. - Pp. 597-652. - URL: https://academic.oup.com/qje/article-abstract/129/2/597/1867065?redirectedFrom=fulltext (дата обращения: 27.10.2020).

7. Collin, D. The Agricultural Productivity Gap / D. Collin, D. Lagakos, V. Waugh. DOI 10.3386/w19628 // National Bureau of Economic Research Working Paper Series. 2013. - Working Paper 19628. - Pp. 1-45. - URL: https://www.nber.org/system/files/working papers/w19628/w19628.pdf (дата обращения: 27.10.2020).

8. Severini, S. The Impact of Agricultural Policy on farm Income Concentration: The Case of Regional Implementation of the CAP Direct Payments in Italy / S. Severini, A. Tantari. - DOI 10.1111/agec.12010 // Agricultural Economics. - 2013. - Vol. 44, issue 3. Pp. 275-286. - URL: https://onlinelibrary.wiley.com/doi/full/10.1111/agec.12010 (дата обращения: 27.10.2020). 
9. Cawan, L. The Role of Strategic and Tactical Flexibility in Managing Input Variability on Farms / L. Cawan, G. Kane, V. Wright. - DOI 10.1002/sres.2137 // Systems Research and Behavioral Science. - 2015. - Vol. 30, issue 4. - Pp. 470-494. - URL: https://onlinelibrary. wiley.com/doi/full/10.1002/sres.2137 (дата обращения: 27.10.2020).

10. Папцов, А. Г. Роль государства в аграрном секторе развитых стран / А. Г. Папцов // АПК: экономика, управление. - 2017. - № 4. - С. 83-87. - URL: https://www. elibrary.ru/item.asp?id=28938306 (дата обращения: 27.10.2020).

11. Гайсин, Р. С. Причины диспаритета цен между сельским хозяйством и промышленностью в свете теории межотраслевого рыночного равновесия / Р. С. Гайсин // Экономика сельскохозяйственных и перерабатывающих предприятий. - 2015. № 10. - C. 18-23. - URL: http://www.eshpp.ru/abstract/2015-10 abst.htm (дата обращения: 27.10.2020). - Рез. англ.

12. Узун, В. Я. Госпрограмма комплексного развития территорий: анализ проекта / В. Я. Узун // Экономическое развитие России. - 2019. - № 5. - С. 30-34. - URL: http://edrussia.ru/images/pdf/2019/05/red 0519_Uzun.pdf (дата обращения: 27.10.2020). - Рез. англ.

13. Швандар, Д. В. Перспективы стабилизации российского рынка молока / Д. В. Швандар, Е. М. Фролова, Т. Ф. Бурова. - DOI 10.24891/fa.10.12.1362 // Финансовая аналитика: проблемы и решения. - 2017. - Т. 10, № 12. - C. 1362-1379. - URL: https:/www.fin-izdat.ru/journal/fa/detail.php?ID=72011 (дата обращения: 27.10.2020). Рез. англ.

14. Милосердов, В. В. Проблемы импортозамещения в системе продовольственной безопасности России / В. В. Милосердов // Известия Международной академии аграрного образования. - 2016. - № 29. - C. 41-47. - URL: https:/www.elibrary.ru/item. asp?id=26932276 (дата обращения: 27.10.2020). - Рез. англ.

15. Асаул, А. Н. Перспективы кластерной организации предпринимательства в агропромышленном комплексе Тувинской Республики / А. Н. Асаул, Б. А. Донгак // Научные труды Вольного экономического общества России. - 2016. - Т. 199, № 3. C. 375-393. - URL: http://veorus.ru/upload/iblock/761/199_veor.pdf (дата обращения: 27.10.2020). - Рез. англ.

16. Ушачев, И. Г. Импортозамещение в агропромышленном комплексе России. Тенденция, проблемы, пути развития / И. Г. Ушачев // Экономика сельскохозяйственных и перерабатывающих предприятий. - 2016. - № 1. - C. 2-10. - URL: http://www. eshpp.ru/abstract/2016-01_abst.htm (дата обращения: 27.10.2020). - Рез. англ.

17. Буздалов, И. Н. О фундаментальных основах аграрной политики / И. Н. Буздалов // Агропродовольственная политика России. - 2016. - № 1. - C. 2-12. - URL: https:/www.elibrary.ru/item.asp?id=26154314 (дата обращения: 27.10.2020).

18. Петриков, А. В. Основные направления и механизмы реализации современной агропродовольственной политики / А. В. Петриков // Экономика сельскохозяйственных и перерабатывающих предприятий. - 2016. - № 1. - C. 11-18. - URL: http://www. eshpp.ru/abstract/2016-01_abst.htm (дата обращения: 27.10.2020). - Рез. англ.

19. Приоритетные направления повышения эффективности малых форм хозяйствования / А. П. Любимов, И. В. Васильева, В. Г. Шафиров [и др.] // Представительная власть - XXI век: законодательство, комментарии, проблемы. - 2019. № 4. - C. 30-33. - URL: http://www.pvlast.ru/archive/index.1293.php (дата обращения: 27.10.2020). - Рез. англ. 
20. Danso-Abbeam, G. Do Farm-Level Technical Efficiency and Welfare Complement Each Other? Insight from Ghana's Cocoa Industry / G. Danso-Abbeam, L. J. S. Baiyegunhi. - DOI 10.1186/s40008-020-00200-w // Journal of Economic Structures. - 2020. Vol. 9. - URL: https://journalofeconomicstructures.springeropen.com/articles/10.1186/ s40008-020-00200-w (дата обращения: 27.10.2020).

Поступила 06.11.2020; одобрена после рецензирования 14.12.2020; принята к публикации 23.12.2020.

Об авторах:

Колесник Наталья Федоровна, профессор кафедры бухгалтерского учета, анализа и аудита ФГБОУ ВО «МГУ им. Н. П. Огарёва» (430005, Российская Федерация, г. Саранск, ул. Большевистская, д. 68/1), доктор экономических наук, ORCID: https:// orcid.org/0000-0003-2323-6799, kolesniknf@mail.ru

Акашева Валентина Вячеславовна, доцент кафедры бухгалтерского учета, анализа и аудита ФГБОУ ВО «МГУ им. Н. П. Огарёва» (430005, Российская Федерация, г. Саранск, ул. Большевистская, д. 68/1), кандидат экономических наук, ORCID: https:// orcid.org/0000-0003-3635-7629, valakasheva@mail.ru

Шибилева Ольга Викторовна, доцент кафедры бухгалтерского учета, анализа и аудита ФГБОУ ВО «МГУ им. Н. П. Огарёва» (430005, Российская Федерация, г. Саранск, ул. Большевистская, д. 68/1), кандидат экономических наук, ORCID: https:// orcid.org/0000-0001-7628-3527, o.shibileva@rambler.ru

Заявленный вклад авторов:

Н. Ф. Колесник - постановка проблемы исследования; научное руководство; формулирование основной концепции исследования; формулирование результатов исследования и выводов; критический анализ и доработка текста.

В. В. Акашева - подготовка текста статьи; проведение критического анализа материалов, формулирование выводов и рекомендаций.

О. В. Шибилева - подготовка текста статьи; проведение критического анализа материалов; формулирование выводов и рекомендаций.

Авторы прочитали и одобрили окончательный вариант рукописи.

\section{REFERENCES}

1. Zinchenko A.P. Private Farm Enterprises according to the Results of All-Russian Agricultural Censuses. Izvestiya Timiryazevskoj selskokhozyajstvennoj akademii = Izvestiya of Timiryazev Agricultural Academy. 2019; (2):119-128. (In Russ., abstract in Eng.) DOI: https://doi.org/10.34677/0021-342x-2019-2-119-128

2. Altukhov A.I. Improving the Organizational-Economic Mechanism for Stable Development of the Agroindustrial Production. Ehkonomika selskokhozyajstvennykh i pererabatyvayushhikh predpriyatij = Economy of Agricultural and Processing Enterprises. 2016; (7):2-11. Available at: http://www.eshpp.ru/abstract/2016-07_abst.htm (accessed 27.10.2020). (In Russ., abstract in Eng.) 
3. Bashmachnikov V.F., Drokin V.V., Zhuravlev A.S. Involvement of Rural Households in Solving the Problems of Import Substitution. Ehkonomika regiona = Economy of Region. 2018; 14(2):663-675. (In Russ., abstract in Eng.) DOI: https://doi.org/10.17059/2018-2-26

4. Kizos T., Marin-Guirao J.I., Georgiadi M.-E., et al. Survival Strategies of Farm Households and Multifunctional Farms in Greece. The Geographical Journal. 2011; 177(4):335346. (In Eng.) DOI: https://doi.org/10.1111/j.1475-4959.2011.00403.x

5. Young A. Inequality, the Urban-Rural Gap and Migration. The Quarterly Journal of Economics. 2013; 128(4):1727-1789. (In Eng.) DOI: https://doi.org/10.1093/qje/qjt025

6. Karlan D., Osei R., Osei-Akoto I., Udry C. Agricultural Decisions after Relaxing Credit and Risk Constraints. The Quarterly Journal of Economics. 2014; 129(2):597-652. (In Eng.) DOI: https://doi.org/10.1093/qje/qju002

7. Collin D., Lagakos D., Waugh V. The Agricultural Productivity Gap. National Bureau of Economic Research Working Paper Series. 2013. p. 1-45. (In Eng.) DOI: https:// doi.org/10.3386/w19628

8. Severini S., Tantari A. The Impact of Agricultural Policy on farm Income Concentration: The Case of Regional Implementation of the CAP Direct Payments in Italy. Agricultural Economics. 2013; 44(3):275-286. (In Eng.) DOI: https://doi.org/10.1111/agec.12010

9. Cawan L., Kane G., Wright V. The Role of Strategic and Tactical Flexibility in Managing Input Variability on Farms. Systems Research and Behavioral Science. 2015. 30(4):470-494. (In Eng.) DOI: https://doi.org/10.1002/sres.2137

10. Paptsov A.G. The Role of the State in the Agrarian Sector of Developed Countries. APK: ehkonomika, upravlenie = Agro-Industrial Complex: Economy, Management. 2017; (4):83-87. Available at: https://www.elibrary.ru/item.asp?id=28938306 (accessed 27.10.2020). (In Russ.)

11. Gaisin R.S. Reasons of Price Disparity between Agriculture and Industry in the Light of the Theory of Interbranchial Market Balance. Ehkonomika selskokhozyajstvennykh i pererabatyvayushhikh predpriyatij = Economy of Agricultural and Processing Enterprises. 2015; (10):18-23. Available at: http://www.eshpp.ru/abstract/2015-10_abst.htm (accessed 27.10.2020). (In Russ., abstract in Eng.)

12. Uzun V.Ya. State Program of Integrated Development of Rural Territories: Project Analysis. Ehkonomicheskoe razvitie Rossii = Russian Economic Developments. 2019; (5):30-34. Available at: http://edrussia.ru/images/pdf/2019/05/red_0519_Uzun.pdf (accessed 27.10.2020). (In Russ., abstract in Eng.)

13. Shvandar D. V., Frolova E.M., Burova T.F. The Prospects of Stabilization of the Russian Milk Market. Finansovaya analitika: problemy $i$ resheniya $=$ Financial Analytics: Science and Experience. 2017; 10(12):1362-1379. (In Russ., abstract in Eng.) DOI: https:// doi.org/10.24891/fa.10.12.1362

14. Miloserdov V.V. Problems of Import Substitution in the System of Food Security of Russia. Izvestiya Mezhdunarodnoj akademii agrarnogo obrazovaniya = Proceedings of the International Academy of Agrarian Education. 2016; (29):41-47. Available at: https://www. elibrary.ru/item.asp?id=26932276 (accessed 27.10.2020). (In Russ., abstract in Eng.)

15. Asaul A.N., Dongak B.A. Prospects of the Cluster Form of Entrepreneurship in the Agro-Industrial Complex of the Tuva Republic. Nauchnye trudy Volnogo ehkonomicheskogo obshhestva Rossii = Scientific Works of the Free Economic Society of Russia. 2016; 199(3):375-393. Available at: https://www.elibrary.ru/item.asp?id=26932276 (accessed 27.10.2020). (In Russ., abstract in Eng.) 
16. Ushachev I.G. Import Substitution in Agroindustrial Complex of Russia: Trends, Problems, Ways of Development. Ehkonomika selskokhozyajstvennykh i pererabatyvayushhikh predpriyatij = Economy of Agricultural and Processing Enterprises. 2016; (1):2-10. Available at: http://www.eshpp.ru/abstract/2016-01 abst.htm (accessed 27.10.2020). (In Russ., abstract in Eng.)

17. Buzdalov I.N. On the Fundamental Foundations of Agrarian Policy. Agroprodovolstvennaya politika Rossii = Agri-Food Policy in Russia. 2016; (1):2-12. Available at: https:// www.elibrary.ru/item.asp?id=26154314 (accessed 27.10.2020). (In Russ.)

18. Petrikov A.V. Main Lines and Mechanisms for Realizing Modern Agrifood Policy. Ehkonomika selskokhozyajstvennykh $i$ pererabatyvayushhikh predpriyatij = Economy of Agricultural and Processing Enterprises. 2016; (1):11-18. Available at: http:/www.eshpp. ru/abstract/2016-01_abst.htm (accessed 27.10.2020). (In Russ., abstract in Eng.)

19. Lyubimov A.P., Vasilieva I.V., Shafirov V.G., Mozhaev E.E., Markov A.K. Priority Areas for Improving the Efficiency of Small Businesses. Predstavitelnaya vlast - XXI vek: zakonodatelstvo, kommentarii, problemy $=$ Representative Power $-21^{\text {st }}$ Century: Legislation, Comments, Problems. 2019; (4):30-33. Available at: http://www.pvlast.ru/archive/index.1293.php (accessed 27.10.2020). (In Russ., abstract in Eng.)

20. Danso-Abbeam G., Baiyegunhi L.J.S. Do Farm-Level Technical Efficiency and Welfare Complement Each Other? Insight from Ghana's Cocoa Industry. Journal of Economic Structures. 2020; 9. Article 23. (In Eng.) DOI: https://doi.org/10.1186/s40008-020-00200-W

Submitted 06.11.2020; approved after reviewing 14.12.2020; accepted for publication 23.12.2020.

About the authors:

Natalya F. Kolesnik, Professor, Department of Accounting, Analysis and Audit, National Research Mordovia State University (68/1 Bolshevistskaya St., Saransk 430005, Russian Federation), Dr. Sci. (Economics), ORCID: https://orcid.org/0000-0003-2323-6799, kolesniknf@mail.ru

Valentina V. Akasheva, Associate Professor, Department of Accounting, Analysis and Audit, National Research Mordovia State University (68/1 Bolshevistskaya St., Saransk 430005, Russian Federation), Cand. Sci. (Economics), ORCID: https://orcid.org/00000003-3635-7629, valakasheva@mail.ru

Olga V. Shibileva, Associate Professor, Department of Accounting, Analysis and Audit, National Research Mordovia State University (68/1 Bolshevistskaya St., Saransk 430005, Russian Federation), Cand. Sci. (Economics), ORCID: https://orcid.org/0000-0001-76283527, o.shibileva@rambler.ru

\section{Contribution of the authors:}

N. F. Kolesnik - statement of the research problem; academic supervision; formulation of the basic concept of the study; evaluation of the results; drawing conclusions; critical analysis and revision of the text.

V. V. Akasheva - preparation of the text of the article; critical analysis of the materials; drawing conclusions; putting forward recommendations.

O. V. Shibileva - preparation of the text of the article; critical analysis of the materials; drawing conclusions; putting forward recommendations.

The authors have read and approved the final version of the manuscript. 
УдК 330.16

DOI: $10.15507 / 2413-1407.115 .029 .202102 .401-426$

Оригинальная статья / Original article http://regionsar.ru

ISSN 2587-8549 (Print)

ISSN 2413-1407 (Online)

\section{Экономическая безопасность в границах экономической сложности}

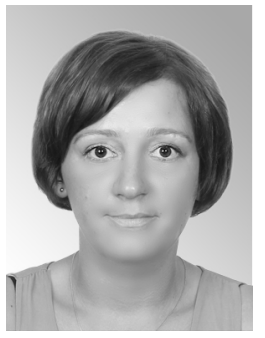

К. Ю. Волошенко

ФГАОУ ВО «Балтийский федеральный университет имени Иммануила Канта» (г. Калининград,

Российская Федерачия), kvoloshenko@kantiana.ru

Введение. Новую научную проблему в изучении экономической безопасности регионов, особенно отличающихся специфическим положением, составляют вопросы ее обеспечения с учетом влияния экономической сложности. Развитие регионов, прежде всего приграничных, обусловлено действием двух разнонаправленных процессов: ростом экономической сложности, определяемой внешними ограничениями или возможностями, против экономической безопасности, связанной с внутренним потенциалом и ресурсами региона. Цель статьи - на основе проведенного исследования установить особенности взаимосвязи экономической безопасности с экономической сложностью, формирующей инновационно-технологические границы роста и развития территорий.

Материалы и методы. Проведены семантический анализ и тематическая кластеризация экономической безопасности с использованием данных библиографических и реферативных баз публикаций: англоязычных (Web of Science) и русскоязычных (eLIBRARY.RU). Измерение экономической сложности основано на анализе внешнеторговой статистики Комтрейд OOH (UN Comtrade). В оценке экономической безопасности использованы официальные данные, публикуемые Росстатом.

Результаты исследования. Определена терминологическая связь экономической безопасности и экономической сложности, дано теоретическое представление отношений и взаимообусловленности категорий. Разработаны методические положения изучения обеспечения экономической безопасности приграничного региона с учетом выбора направлений роста его экономической сложности.

Обсуждение и заключение. В условиях действия системных ограничений в развитии региона экономическая безопасность в значительной мере определяется как имеющимися внутренним потенциалом и ресурсами, так и возможностями их использования. Однако новые компетенции региона формируются в процессе роста сложности экономики, поэтому экономическая безопасность устанавливается в ее границах. Собственно приоритет между поддержанием уровня экономической безопасности или ростом экономической сложности обусловливает выбор ключевых направлений структурной трансформации экономики региона. Рассмотренные в работе механизм и критерии, а также методические положения такого выбора важны с позиций развития теории экономической безопасности и экономической сложности на региональном уровне и имеют практическое значение для регионального управления.

(C) Волошенко К. Ю., 2021

Контент доступен под лицензией Creative Commons Attribution 4.0 License. This work is licensed under a Creative Commons Attribution 4.0 License. 
Ключевые слова: экономическая безопасность, экономическая сложность, приграничный регион, индикатор, абсорбционная способность

Автор заявляет об отсутствии конфликта интересов.

Финансирование. Исследование выполнено при финансовой поддержке РФФИ и Правительства Калининградской области в рамках научного проекта № 19-410-390002.

Для цитирования: Волошенко, К. Ю. Экономическая безопасность в границах экономической сложности / К. Ю. Волошенко. - DOI 10.15507/2413-1407.115.029.202102.401426 // Регионология. - 2021. - Т. 29, № 2. - С. 401-426.

\title{
Economic Security within the Limits of Economic Complexity
}

\author{
K. Yu. Voloshenko \\ Immanuel Kant Baltic Federal University (Kaliningrad, Russian Federation), \\ kvoloshenko@kantiana.ru
}

Introduction. The issues of ensuring economic security of regions (especially of those with a specific situation) taking into account the influence of economic complexity are a novel research problem. The development of regions, primarily the border ones, is determined by two divergent processes: growing economic complexity, determined by external constraints or opportunities, and economic security, associated with the internal potential and resources of the region. Based on the study conducted, the article reveals the features of the interconnection between economic security and economic complexity, the latter determining the innovative and technological limitations to the growth and development of territories.

Materials and Methods. The author has conducted semantic analysis and thematic clustering of economic security using data from bibliographic and reference databases of publications in English (Web of Science) and in Russian (eLIBRARY.RU). The assessment of economic complexity was based on the conducted analysis of the UN Comtrade foreign trade statistics, that of economic security - on the official data published by Rosstat.

Results. The author has identified the terminological connection between economic security and economic complexity, and has provided a theoretical representation of the relations and interdependence of these categories. The paper presents the methodological provisions for studying the economic security of border regions, taking into consideration the possibilities for increasing their economic complexity.

Discussion and Conclusion. In the context of systemic constraints in the development of the region, economic security is largely determined by both the available internal potential and resources, and the possibilities of their use. However, the region gains new capabilities with the increase in its economic complexity, the latter also limiting its economic security. In fact, the choice of key areas for the structural transformation of the region's economy depends on whether priority is given to maintaining the level of economic security or increasing economic complexity. The mechanism and criteria discussed in this paper, as well as the methodological provisions of such a choice, contribute to further development of the theory of economic security and economic complexity at the regional level and are of practical importance for regional governance.

Keywords: economic security, economic complexity, border region, indicator, absorption capacity

The author declares that there is no conflict of interest. 
Funding. The study was conducted with the financial support from the Russian Foundation for Basic Research and the Government of the Kaliningrad Region as part of the scientific project No. 19-410-390002.

For citation: Voloshenko K.Yu. Economic Security within the Limits of Economic Complexity. Regionology = Russian Journal of Regional Studies. 2021; 29(2):401-426. DOI: https://doi.org/10.15507/2413-1407.115.029.202102.401-426

Введение. В условиях новых вызовов и происходящих изменений на уровне отдельных стран и регионов, продиктованных непростой международной ситуацией, сложными внутренними условиями их развития и усугубляемых влиянием пандемии коронавирусной инфекции COVID-19, актуализируются вопросы обеспечения экономической безопасности. В работах зарубежных и отечественных авторов сформированы теоретические основы экономической безопасности, несмотря на то, что само понятие до сих пор остается сложным и неоднозначным ${ }^{1}$. Применительно к территориям различных иерархических уровней экономическая безопасность получила большую проработанность именно в российских исследованиях [1]. Однако по отношению к регионам, характеризующимся специфическими условиями развития в качестве приграничных территорий, проблематика экономической безопасности практически не изучена. Системное исследование указанных вопросов, по сути, было начато в 2018-2020 гг. группой ученых из Калининграда, Санкт-Петербурга, Смоленска, Ростова-на-Дону². В процессе разработки теоретико-методологических основ экономической безопасности применительно к приграничным регионам было установлено, что ее уровень отличается изменчивостью ${ }^{3}$. Ранее нами было выявлено, что значительное влияние на возникновение новых внешних или внутренних угроз, способных существенно изменить позиции региона по экономической безопасности, оказывают современные технологические тренды, а также смена парадигмы создания стоимости (ценности) [1]. Играя главенствующую роль, инновационно-технологическая компонента, изменяя число, структуру и масштабы организаций, влияет на появление новых производств и отраслей, государственное регулирование, политику стран и регионов. Ответом на современные технологические вызовы стало появление новой научной концепции экономической сложности - способность территории, накапливая компетенции, производить больше разнообразной продукции, которая отличается более высоким

${ }^{1}$ Карпов В. В., Кораблева А. А. Теория и практика оценки экономической безопасности (на примере регионов Сибирского федерального округа). Новосибирск, 2017. 146 с.

2 Западное порубежье России: моделирование развития и обеспечение экономической безопасности: моногр. / Г. М. Федоров [и др.]. Калининград: Изд-во БФУ им. И. Канта, 2020. 319 с.; Проблемы экономической безопасности регионов Западного порубежья России / Г. М. Федоров [и др.]. Калининград: Изд-во БФУ им. И. Канта, 2019. 267 с.

${ }^{3}$ Волошенко К. Ю. Экономическая сложность и безопасность в выборе отраслевых стратегий новой промышленной политики // Проблемы регионального развития в начале XXI века : материалы международ. науч. конф. Калининград: Изд-во БФУ им. И. Канта, 2019. С. 103-117. 
уровнем сложности. Под компетенциями понимаются «...технологии, способы или методы работы, ноу-хау, законы и право, институты и инфраструктура, организационные способности, отношенческий капитал и др.» ${ }^{4}$.

На основе результатов проведенных ранее исследований ${ }^{5}$ установлено, что развитие приграничных регионов находится под воздействием разнонаправленных процессов. Во-первых, регионы стремятся к увеличению уровня сложности экономики, что отвечает современным научно-технологическим изменениям рынков, производств, секторов и поддерживается активным их включением в международные экономические отношения. Формируется внешний вектор развития. Во-вторых, все большее значение приобретают вопросы экономической безопасности. Обостряются традиционные и появляются новые угрозы и опасности в связи с сохранением геополитической напряженности и глобальными изменениями. Формируется внутренний вектор развития, поэтому реализация интересов приграничного региона происходит под действием разновекторных сил, в зависимости от соотношения которых выявляются возможности и направления его развития. Это определяет научную проблему взаимосвязи экономической безопасности и экономической сложности.

Цель статьи - на основе результатов проведенного исследования разработать методические положения изучения экономической безопасности приграничных регионов с учетом ее взаимообусловленности с экономической сложностью в обосновании выбора ключевых направлений развития.

Логика исследования предполагает уточнение содержания категории экономической безопасности на основе семантического анализа посредством измерения с использованием авторских подходов экономической безопасности и экономической сложности (на примере Калининградской области), выявление методических особенностей их изучения. На этой основе устанавливается их связь и взаимообусловленность и проводится последующая разработка методических положений в части реализации модели экономической безопасности региона с учетом требований экономической сложности.

Обзор литературы. Теоретический обзор отечественных и зарубежных работ проводился нами в более ранних исследованиях по экономической безопасности региона [1] и экономической сложности [2]. Учитывая слабую изученность указанных вопросов на уровне приграничных регионов, рассмотрим их подробнее.

Проблемы соотношения между безопасностью и открытостью границы изучаются учеными Института географии РАН (В. А. Колосовым, В. А. Шупером), Института экономики РАН (Л. Б. Вардомским), Института Европы РАН (Н. М. Межевичем) и МГУ им. М. В. Ломоносова (Н. С. Мироненко, А. Н. Пилясовым, В. Н. Стрелецким). Ими обосновывается преодоление

\footnotetext{
${ }^{4}$ Там же. С. 107.

${ }^{5}$ Проблемы экономической безопасности регионов Западного порубежья России / Г. М. Федоров [и др.]. 2019; Волошенко К. Ю. Экономическая сложность и безопасность в выборе отраслевых стратегий новой промышленной политики.
} 
противоречий между интересами безопасности и выгодами свободных взаимодействий, исследуется вопрос «экономической автаркии» ${ }^{6}[3$, с. 70$]$.

Проблематика пространственной дифференциации территориальных структур хозяйства представлена в исследованиях ученых Тихоокеанского института географии ДВО РАН (П. Я. Бакланова, С. С. Ганзея, А. В. Мошкова) и Института экономических исследований ДВО РАН (Д. С. Вишневского, А. Н. Демьяненко, О. М. Прокапало) ${ }^{7}$ [4]. Применительно к территориям Дальнего Востока России изучаются внутренние детерминанты, которые в значительной степени определяют уровень их экономической безопасности.

Причины территориальных различий в уровнях экономической безопасности приграничных регионов анализируются в работах ученых Российской академии народного хозяйства и государственной службы при Президенте Российской Федерации ${ }^{8}$. Развитие приграничных субъектов России, направления приграничных взаимодействий, стратегические перспективы исследуются учеными Южно-Уральского государственного университета 9 .

Помимо общих вопросов теории экономической безопасности особое внимание уделяется формированию ее экономико-правовых положений. Проблематика представлена в публикациях ученых Московского и СанктПетербургского институтов МВД России ${ }^{10}$.

Необходимо отметить работы исследователей Вологодского научного центра Российской академии наук (Н. В. Ворошиловой, В. А. Ильиной, И. А. Кондаковой, Т. В. Усковой $)^{11}$. Учеными проводится идентификация вызовов и угроз, подрывающих экономическую безопасность регионов, проблем разорванности экономического пространства и неоднородности развития территорий.

Механизмы сбалансированного и экономически безопасного развития приграничных регионов прорабатывались Советом по изучению производительных сил при Министерстве экономического развития России и Российской академии наук (В. В. Котилко, Ф. С. Пашенных) совместно с Оренбургским государственным университетом (Г. И. Немировой $)^{12}[5]$.

Исследование экономической сложности регионов представлено преимущественно в зарубежных публикациях. Изучаются вопросы ее измерения

\footnotetext{
${ }^{6}$ Колосов В. А., Володин А. Б. Российское пограничье: проблемы развития в новых геополитических условиях. М.: Институт географии РАН, 2019. 180 с.

${ }^{7}$ Бакланов П. Я., Тулохонов А. К. Приграничные и трансграничные территории Азиатской России и сопредельных стран (проблемы и предпосылки устойчивого развития). Новосибирск: Изд-во СО РАН, 2010. 610 с.

${ }^{8}$ Романова Ю. А. Угрозы экономической безопасности современной России: опыт и последствия. М.: Научный консультант, 2017. 175 с.

${ }^{9}$ Карпушкина А. В. Проблемы экономической безопасности: новые решения в условиях ключевых трендов экономического развития. Челябинск: Изд. центр ЮУрГУ, 2020. 461 с.

10 Экономическая безопасность: концептуальные подходы и вызовы времени. СПб.: Изд-во С.-Петерб. ун-та МВД России, 2017. 148 с.

${ }^{11}$ Ильин В. А., Ускова Т. В. Национальная безопасность России: проблемы обеспечения экономического роста. Вологда: ИСЭРТ РАН, 2016. 300 с.

12 Немирова Г. И. Социально-экономическое развитие приграничного региона: теория и практика. М.: Экономика, 2009. 381 с.
} 
и оценки влияния на отдельные сферы и протекающие в региональных системах процессы. Так, Д. Непельски и Дж. Де Прато оценили связь между технологической сложностью городов и их позициями в сети глобально распределенных центров НИОКР [6]. П.-А. Балланд и Д. Ригби для анализа экономической сложности США использовали базу данных патентов и товарных знаков [7]. Т. Буччеллато и Дж. Коро для европейских городов проанализировали кластеры в зависимости от функциональной принадлежности и производственных особенностей территорий [8]. К. Рейнольдс с соавторами на примере Австралии исследуют экспортируемые товары и услуги, которые имеют выявленное сравнительное преимущество [9]. Й. Руус с коллективом авторов изучает применение анализа экономической сложности для обоснования отраслевой политики государства, бизнеса и отдельных сфер [10].

В практическом плане оценка экономической сложности используется для изучения проблем неравенства доходов и ее влияния на экономическое развитие регионов [11]. М. Бандейра Мораис, Дж. Сварт и Дж. А. Джордаан на примере Бразилии установили, что взаимосвязь между экономической сложностью и неравенством доходов имеет перевернутую U-образную форму [12]. И. Ли и Р. Ф.-Й. Лин исследуют выявленные сравнительные преимущества секторов экономики [13].

В других публикациях зарубежных авторов анализируется влияние экономической сложности на рынок труда ${ }^{13}$ [14], взаимосвязь между экономической сложностью и производительностью [15], изучается связь плотности населения в городах и сложности продукции [16]. В отдельных работах рассматривается действие принципа связанности, его влияние на диверсификацию экономики и диффузию знаний [17; 18$]$.

В России в последние годы также растет интерес к теме экономической сложности: исследуются проблемы усложнения экономики регионов [19], структурная трансформация и отраслевая производительность [20], возможности диверсификации экспорта в российских регионах [21-23]. Предпринимались попытки составить карту производственных возможностей регионов России $^{14}$ и атлас экономической сложности регионов России [24]. Серия статей по результатам разработки алгоритма и метода измерения экономической сложности на уровне приграничного региона опубликована коллективом ученых БФУ им. И. Канта ${ }^{15}[2 ; 25-27]$.

${ }^{13}$ Antonis A., Antonios G., Athanasios L. Economic Complexity and Jobs: An Empirical Analysis. MPRA. Paper № 92401. Germany: University Library of Munich, 2019. 27 p.

${ }^{14}$ Improving Regional Performance in Russia: A Capability-Based Approach / F. Farra, N. Klos, U. Schober [et al.]. European Bank for Reconstruction and Development. Working Paper № 155. 2013. 46 p.

${ }^{15}$ Волошенко, К. Ю. Экономическая сложность и безопасность в выборе отраслевых стратегий новой промышленной политики // Проблемы регионального развития в начале XXI века: Материалы междунар. науч. конф. Калининград: Изд-во БФУ им. И. Канта, 2019. C. 103-117; Structural Holes in the Economic Complexity mapping of the Kaliningrad Region / G. Roos, H. Gamble, K. Yu. Voloshenko [et al.] // Балтийский регион - регион сотрудничества. Регионы в условиях глобальных изменений: материалы IV междунар. науч.-практ. конф. Калининград: Изд-во БФУ им. И. Канта, 2020. Т. 4, ч. 3. С. 62-79. 
Вышеупомянутые исследования улучшили понимание экономической безопасности и экономической сложности. Однако они не рассмотрели все возможности и особенности развития региона в соответствии с задачами обеспечения экономической безопасности, а в части экономической сложности - возможности будущего экономического роста за счет развития технологических экосистем и компетенций. Кроме того, указанные подходы сосуществуют независимо, когда с точки зрения развития региона обнаруживается их сильная обусловленность.

Материалы и методы. Изучение связи экономической безопасности и экономической сложности в данной работе проводится на основе результатов: 1) семантического анализа категории экономической безопасности для установления ее терминологической связи с экономической сложностью; 2) формирования теоретического представления отношений экономической безопасности и экономической сложности; 3 ) измерения экономической безопасности с учетом действия фактора приграничности и анализа экономической сложности на примере Калининградской области.

Проведено построение семантических сетей и тематическая кластеризация публикаций (1975-2019 гг.). Источником выступали библиографические и реферативные базы: для англоязычных работ - Web of Science Core Collection (WoS), для русскоязычных - база Научной электронной библиотеки eLIBRARY.RU. Обработка производилась с применением свободно распространяемых программ VOSViewer и Gephi. Общее число анализируемых публикаций по результатам поисковых запросов составило: англоязычных 19685 ед., русскоязычных - 12260 ед.

На основе семантических сетей проводилось построение стратегической диаграммы [28]. Координаты векторов для каждого термина использованы для оценки плотности $(d)$ и центральности $(c)$, характеризующие их связность соответственно внутри и вне кластеров. В первом квадранте содержатся центральные и наиболее заметные темы ( $c>0$ и $d>0)$; второй квадрант включает изолированные темы, которые являются узкоспециальными $(c \leq 0$ и $d>0$ ); третий квадрант - периферийные темы, только появляющиеся или исчезающие $(c<0$ и $d<0)$; четвертый квадрант - неструктурированные темы, которые важны, но слабо развиты ( $c>0$ и $d \leq 0)$.

Методический подход к оценке экономической безопасности представлен в коллективной монографии под редакцией $Г$. М. Федорова ${ }^{16}$, а экономической сложности - в исследовании Й. Рууса, К. Ю. Волошенко, Т. Е. Дрок, Ю. Ю. Фарафоновой [26]. Здесь дадим лишь краткую характеристику применяемых алгоритмов. В соответствии с территориальными особенностями оценки экономической безопасности анализируются факторы экономической безопасности: 1 - общие (для всех регионов), 2 - базовые или основные (для группы

${ }^{16}$ Проблемы экономической безопасности регионов Западного порубежья России / Г. М. Федоров [и др.]. Калининград: Изд-во БФУ им. И. Канта, 2019. 267 с. 
приграничных регионов), 3 - дополнительные или индивидуальные (для отдельных подгрупп или видов регионов в составе приграничных территорий). На этой основе выделяют соответствующие им виды опасностей и угроз, которым противопоставляются общие, частные или специальные индикаторы и устанавливаются их пороговые значения. Далее проводится нормирование индикаторов и рассчитываются их интегральные индексы. В зависимости от значений индексов фиксируется принадлежность региона к зонам экономической безопасности: до 0,25 - катастрофический риск, от 0,25 до 0,50 - критический риск, от 0,50 до 0,75 - значительный риск, от 0,75 до 1,0 - умеренный риск, более 1,0 - стабильность.

В соответствии с разработанным авторским подходом к измерению экономической сложности региона [26] проводится оценка распространенности и дифференциации экспортной корзины региона в мировом продуктовом пространстве. Базы данных мировой торговли перед расчетом показателей экономической сложности подлежат корректировке и дополнению: 1) отражаются торговые потоки искомого региона с каждой отдельной страной; 2) очищаются экспортно-импортные торговые потоки страны искомого региона на экспортно-импортные операции п. 1; 3) в базу включаются вывоз и ввоз продукции межрегиональной торговли. Указанные технические меры позволяют измерить возможности роста разнообразия и сложности продукции за счет товаров, участвующих как во внешней, так и во внутренней торговле. Далее с использованием разработанной базы мировой торговой статистики проводится ее программная обработка и расчет показателей экономической сложности $[9 ; 29]$.

Материалы по результатам измерения экономической безопасности и экономической сложности на примере Калининградской области послужили основанием для разработки методического обеспечения реализации модели экономической безопасности региона с учетом роста его экономической сложности.

Результаты исследования. По итогам тематической кластеризации были установлены современные направления изучения экономической безопасности. В составе англоязычных публикаций выделено 4 кластера (рис. 1a), русскоязычных - 14 (рис. 1б).

В стратегической диаграмме получено распределение включенных в них тем (рис. 2, таблица): центральные - $\mathrm{K}_{2}, \mathrm{~K}_{8}, \mathrm{~K}_{14}, \mathrm{~K}_{2}$ (WoS), $\mathrm{K}_{4}(\mathrm{WoS})$; изолированные - $\mathrm{K}_{5}, \mathrm{~K}_{7}, \mathrm{~K}_{10}, \mathrm{~K}_{12}$; периферийные - $\mathrm{K}_{3}, \mathrm{~K}_{9}, \mathrm{~K}_{11}$; неструктурированные $\mathrm{K}_{1}, \mathrm{~K}_{4}, \mathrm{~K}_{6}, \mathrm{~K}_{13}, \mathrm{~K}_{1}(\mathrm{WoS}), \mathrm{K}_{3}(\mathrm{WoS})$.

С точки зрения развития теории экономической безопасности, в том числе для установления ее связи с экономической сложностью, наиболее важное значение имеют именно периферийные и неструктурированные темы. По итогам анализа к ним относятся общие теоретические и методологические вопросы, а также проблемы управления и обеспечения экономической безопасности. 


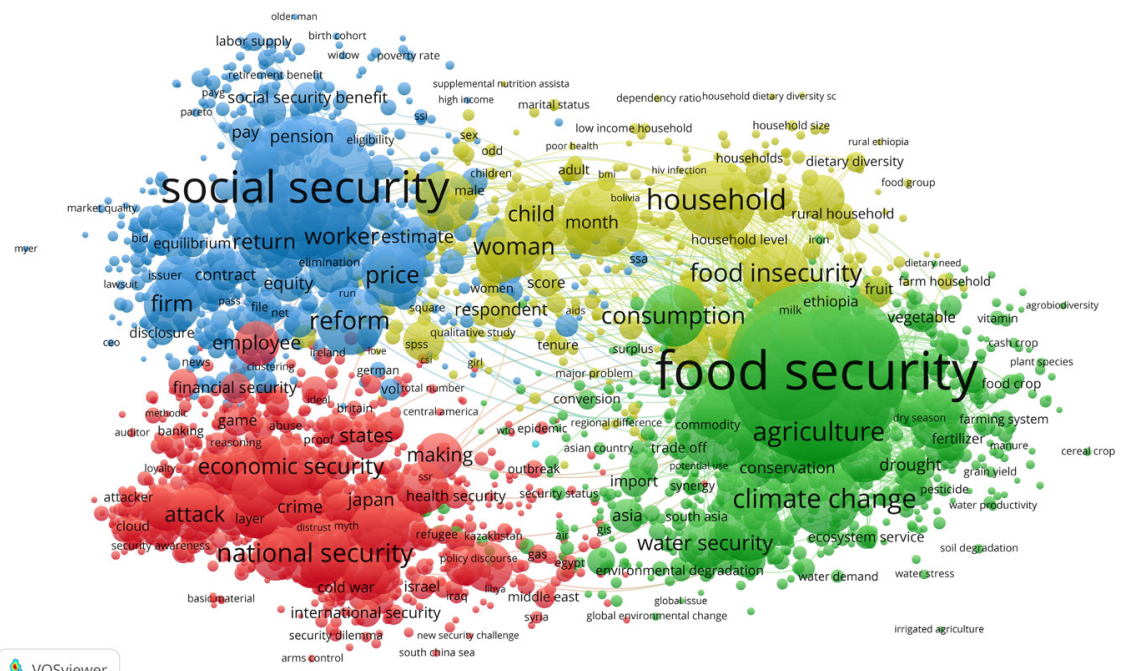

\& vosviewer

a) англоязычные публикации (Web of Science) / Publications in English (Web of Science)

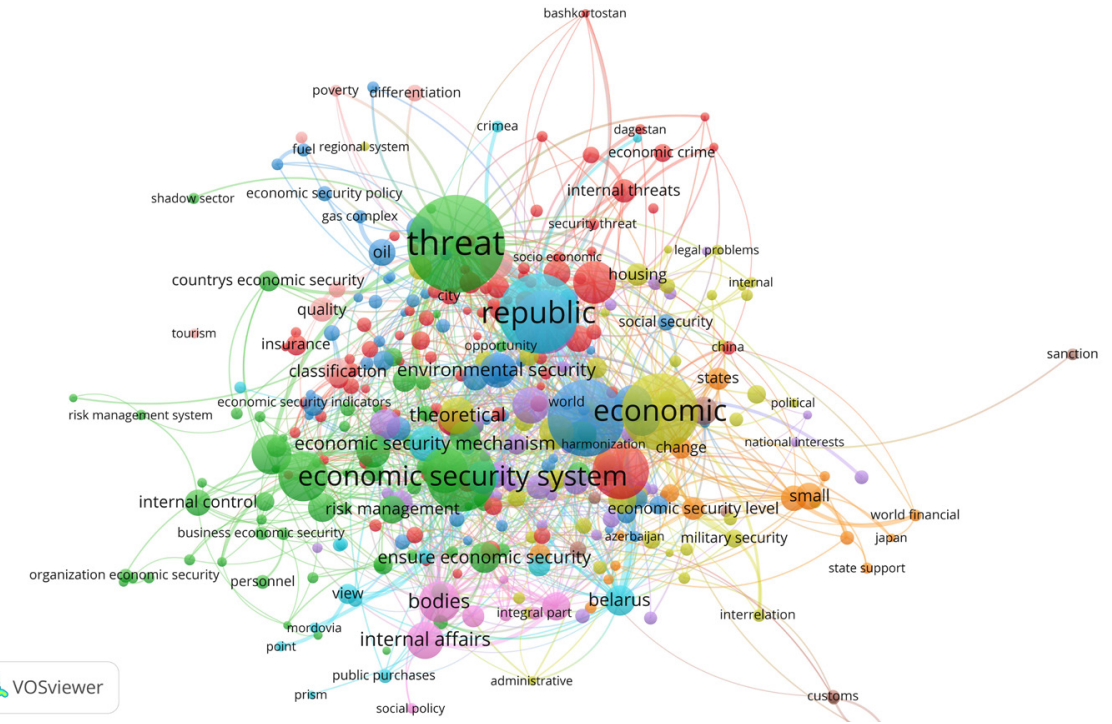

б) русскоязычные публикации (eLIBRARY.RU) / Publications in Russian (eLIBRARY.RU)

Р и с. 1. Семантические сети по экономической безопасности

F i g. 1. Semantic networks for economic security 
Включают термины, связанные с управлением и развитием знаний (текущих, новых и локальных), торговой либерализацией, формированием новых производственных возможностей, экономической интеграцией и сотрудничеством, а также технологиями (информационными, коммуникационными, цифровыми и др.) и инновационным развитием. Состав ключевых тем по результатам семантического анализа подтверждает, что для экономической безопасности значение приобретает способность региона генерировать новые знания, исходя из сложившегося инновационно-технологического уровня, а также степени его вовлеченности в международные отношения.

Именно указанные проблемы доминируют в теории экономической сложности. Отношения экономической безопасности и экономической сложности ставят вопросы об их качестве и содержании. Каковы механизмы, формирующие их взаимосвязь? Что для региона является приоритетным - развитие экономической сложности или поддержание экономической безопасности? Что из них является целью и ограничением, при каких условиях происходит смена приоритетов? d, плотность / density

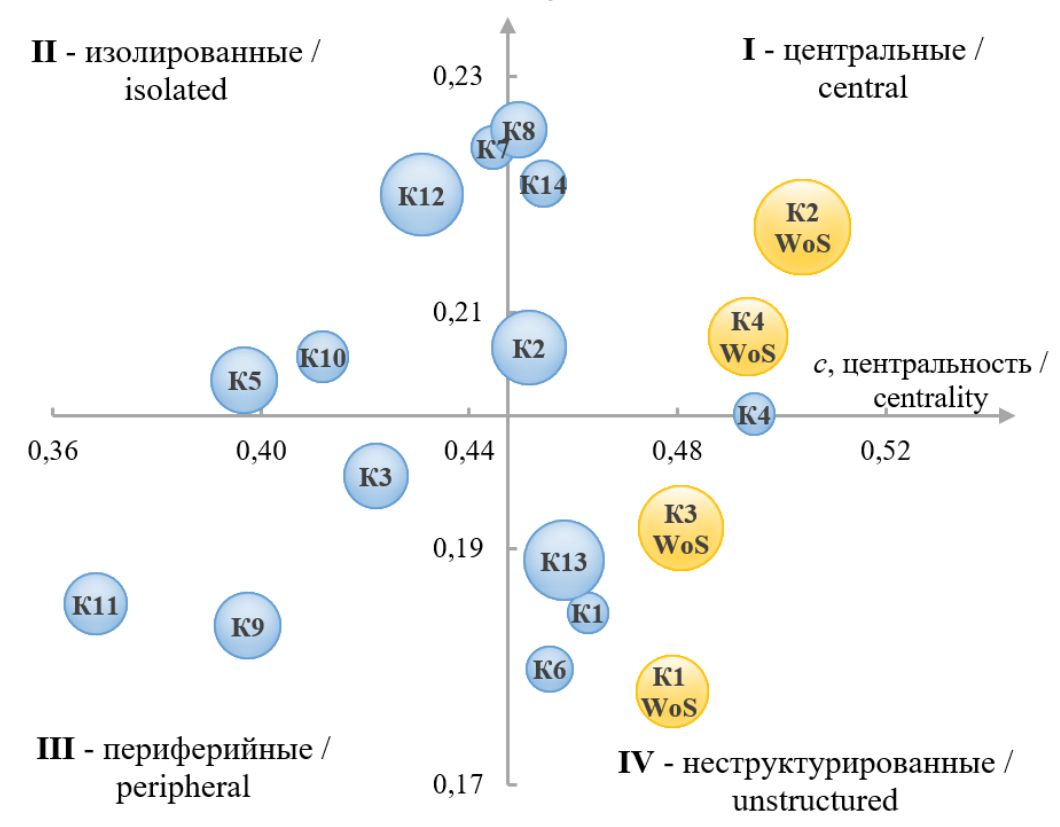

Р и с. 2. Стратегическая диаграмма терминов

F i g. 2. Strategic diagram of terms 
T а б л и ц а. Содержание кластеров семантических сетей (eLIBRARY.RU и Web of Science)

$\mathrm{T}$ a b 1 e. Content of Semantic Network Clusters (eLIBRARY.RU and Web of Science)

\begin{tabular}{|c|c|c|}
\hline $\begin{array}{c}\text { Кластер / } \\
\text { Cluster }\end{array}$ & $\begin{array}{c}\text { Размер кластера } \\
\text { (по релевантным } \\
\text { терминам)/ } \\
\text { Cluster size (by } \\
\text { relevant terms) }\end{array}$ & Тематика кластера / Cluster topic \\
\hline $\mathrm{K}_{1}$ & 45 & $\begin{array}{l}\text { Методические вопросы экономической безопасности / } \\
\text { Methodological issues of economic security }\end{array}$ \\
\hline $\mathrm{K}_{2}$ & 38 & $\begin{array}{l}\text { Экономическая безопасность России / Economic secu- } \\
\text { rity of Russia }\end{array}$ \\
\hline $\mathrm{K}_{3}$ & 35 & $\begin{array}{l}\text { Экономическая безопасность личности и бизнеса } \\
\text { Economic security of individuals and businesses }\end{array}$ \\
\hline $\mathrm{K}_{4}$ & 31 & $\begin{array}{l}\text { Преступления и коррупция в экономической безопас- } \\
\text { ности / Crime and corruption in economic security }\end{array}$ \\
\hline $\mathrm{K}_{5}$ & 30 & $\begin{array}{l}\text { Современные проблемы экономической безопасности / } \\
\text { Modern problems of economic security }\end{array}$ \\
\hline $\mathrm{K}_{6}$ & 28 & $\begin{array}{l}\text { Управление и обеспечение экономической безопасно- } \\
\text { сти / Management and ensuring economic security }\end{array}$ \\
\hline $\mathrm{K}_{7}$ & 27 & $\begin{array}{l}\text { Экономические интересы и безопасность / Economic } \\
\text { interests and security }\end{array}$ \\
\hline $\mathrm{K}_{8}$ & 25 & $\begin{array}{l}\text { Экономические кризисы, санкции и безопасность } \\
\text { Economic crises, sanctions, and security }\end{array}$ \\
\hline $\mathrm{K}_{9}$ & 24 & $\begin{array}{l}\text { Продовольственная безопасность: теория и практика / } \\
\text { Food security: theory and practice }\end{array}$ \\
\hline $\mathrm{K}_{10}$ & 20 & $\begin{array}{l}\text { Законодательные и правовые вопросы безопасности / } \\
\text { Legislative and legal security issues }\end{array}$ \\
\hline $\mathrm{K}_{11}$ & 20 & $\begin{array}{l}\text { Экологическая безопасность и экономические интере- } \\
\text { сы / Environmental safety and economic interests }\end{array}$ \\
\hline $\mathrm{K}_{12}$ & 15 & $\begin{array}{l}\text { Экономическая безопасность конкретных территорий / } \\
\text { Economic security of specific territories }\end{array}$ \\
\hline $\mathrm{K}_{13}$ & 12 & $\begin{array}{l}\text { Государственные органы власти и безопасность / Pub- } \\
\text { lic authorities and security }\end{array}$ \\
\hline $\mathrm{K}_{14}$ & 9 & $\begin{array}{l}\text { Международные аспекты экономической безопасно- } \\
\text { сти / International issues of economic security }\end{array}$ \\
\hline $\mathrm{K}_{1}(\mathrm{WoS})$ & 1094 & $\begin{array}{l}\text { Общие проблемы обеспечения национальной безопас- } \\
\text { ности / General problems of ensuring national security }\end{array}$ \\
\hline $\mathrm{K}_{2}(\mathrm{WoS})$ & 665 & Продовольственная безопасность / Food security \\
\hline $\mathrm{K}_{3}(\mathrm{WoS})$ & 616 & Социальная безопасность / Social security \\
\hline $\mathrm{K}_{4}(\mathrm{WoS})$ & 387 & $\begin{array}{l}\text { Узкие темы и вопросы экономической безопасности / } \\
\text { Specific topics and issues of economic security }\end{array}$ \\
\hline
\end{tabular}


Конечно, это лишь часть возникающих вопросов и во многом они выходят за границы данного исследования. Однако для решения поставленных задач в работе необходимо привести их общее теоретическое представление (рис. 3).

Взаимосвязь экономической безопасности и экономической сложности, на наш взгляд, определяется механизмом устойчивости. Последняя предполагает способность региональной системы оставаться относительно неизменной вопреки внутренним и внешним возмущениям. Неизменность определяется динамическим равновесием.

Так, ослабление или усиление влияния угроз и опасностей продуцируют дисбалансы. Для их устранения внутри региональной системы происходят преобразования, посредством которых устанавливается равновесие более высокого уровня, как следствие, формируется устойчивость нового типа. Если устойчивость обеспечивается через рост защищенности региональной системы, то ключевое значение приобретает экономическая безопасность. Экономическая сложность здесь сопровождает структурные изменения.

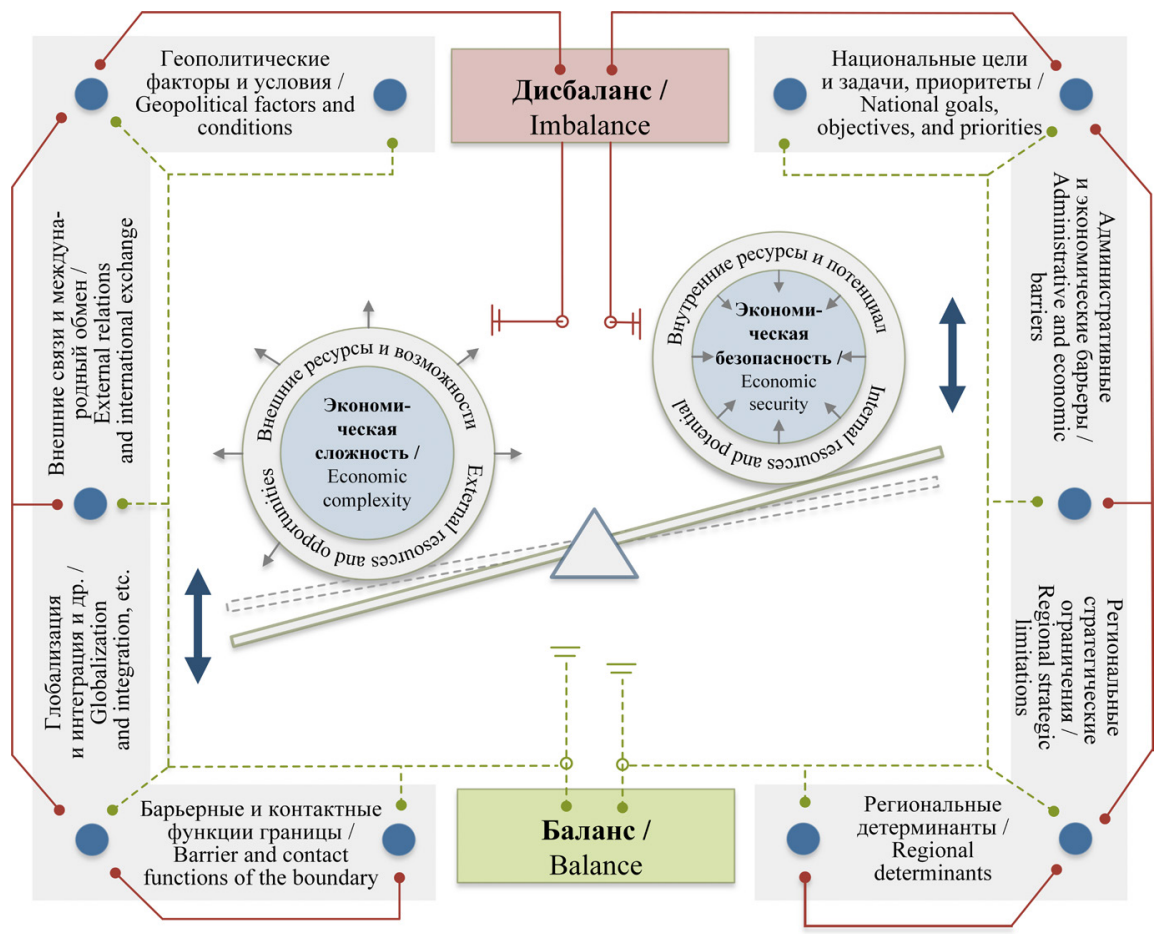

Р и с. 3. Связь экономической безопасности и экономической сложности

F i g. 3. Connection between economic security and economic complexity 
Если устойчивость региона зависит от роста и расширения потенциала, то основная роль переходит к экономической сложности, а экономическая безопасность выступает в качестве ограничения. В описанных вариантах отношений экономическая сложность устанавливает границы для экономической безопасности: чем больше возможностей для роста сложности экономики, тем шире и границы экономической безопасности, верно и обратное. Данная зависимость объясняется ведущей ролью научно-технологического и инновационного векторов экономического роста и его обусловленностью, согласно терминологии экономической сложности, широтой и глубиной базы производственных возможностей и компетенций региона. Поэтому приоритизация экономической безопасности и экономической сложности происходит в конкретных пространственно-временных условиях. Они различны для регионов, зависят от действия определенных факторов и для изучаемого нами типа регионов представлены «центральными силами» приграничья. На рисунке 3 обозначены наиболее значимые факторы: соотношение барьерных и контактных функций границы, глобализация и интеграция, интенсивность внешних связей и включенность региона в международный обмен, геополитические факторы и условия (турбулентность), региональные детерминанты, национальные цели, задачи и приоритеты, региональные стратегические ограничения, административные и экономические барьеры. Bсе факторы могут иметь разнонаправленное действие: при положительном (зеленый контур) - способствуют достижению или поддержанию баланса, при отрицательном (красный контур) - вызывают или усиливают дисбалансы.

Очевидно, что в современных условиях напряженной геополитической обстановки и сложной ситуации в мировой экономике в целом, когда наблюдается изменение географии связей, усиливаются протекционистские настроения стран, растут барьеры входа на рынки, сокращаются цепочки поставок, актуализируется поддержка экономической безопасности приграничных регионов. Экономическая сложность выполняет функции в части роста компетенций и потенциала региона, который может быть задействован в будущем при более благоприятной международной обстановке за счет расширения объемов экспорта более сложной продукции.

Для подтверждения приведенных выше положений и последующей разработки методического обеспечения экономической безопасности в границах экономической сложности учитывались результаты ее оценки на примере Калининградской области. Проведен анализ влияния «центральных сил» приграничья, на основе которых были идентифицированы опасности и угрозы, факторы экономической безопасности, разработана система индикаторов [1]. Результаты представлены на рисунке 4.

Уровень экономической безопасности Калининградской области изменялся в течение исследуемого периода в границах умеренного и значительного рисков. Причем лучшие значения наблюдались по общим показателям, установленным для всех регионов России, а с учетом влияния приграничной специфики были гораздо хуже. 


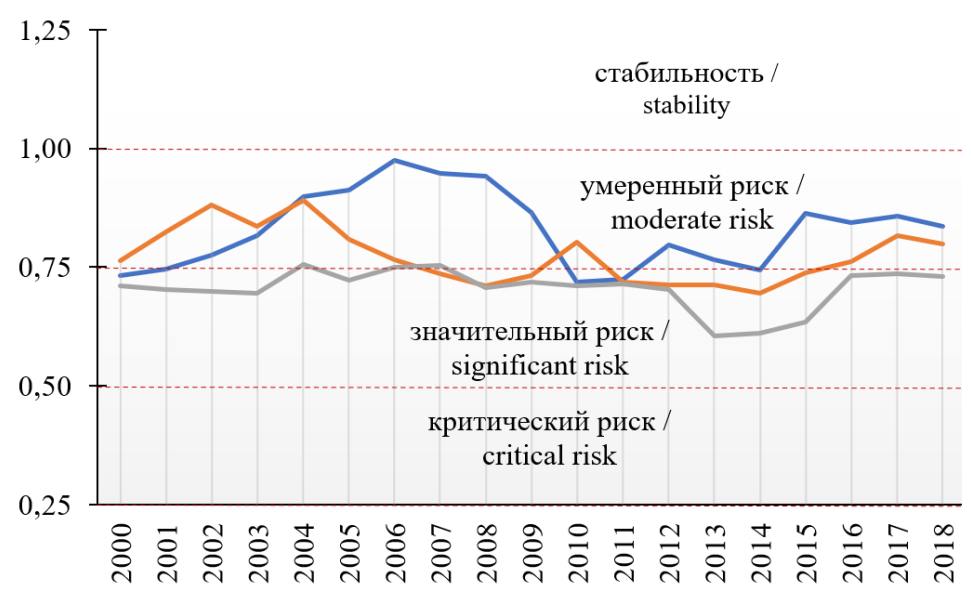

— Общий субиндекс / General sub-index

— Частный субиндекс / Separate sub-index

Специальный субиндекс / Special sub-index

a) значения субиндексов / sub-indices
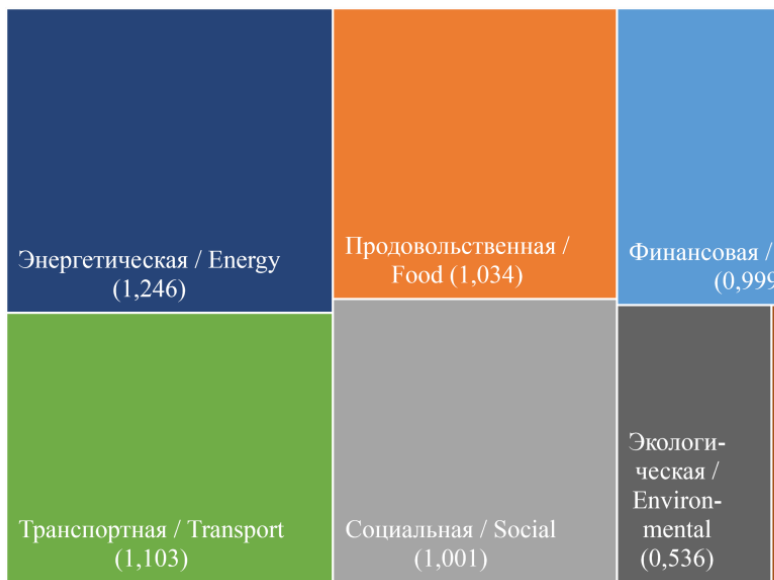

.


При анализе структуры специального индекса (рис. 4б), у нас вызывает опасение ситуация в области инновационной, внешнеэкономической, экологической, демографической безопасности. Прочие индикаторы безопасности характеризуют готовность региона к цифровизации и технологическому прорыву, которые находятся в зоне критического риска. За исключением демографических и экологических условий, все они касаются действующей модели развития региона. Влияние оказывают импортная зависимость, высокая внешнеэкономическая составляющая и низкий инновационно-технологический уровень. Согласно предложенной нами теоретической модели взаимосвязи безопасности и сложности, в настоящее время для Калининградской области стоит цель поддержания экономической безопасности.

Сложность экономики устанавливает ее границы с позиций получения новых знаний и компетенций, развития его абсорбционных способностей. Выявление указанных направлений развития осуществлялось в рамках анализа экономической сложности региона.

Анализ экономической сложности на примере Калининградской области проведен по состоянию на 2018 г. [26] в связи с присутствием временного лага в публикации данных мировой торговли. Оценка продуктового пространства для Калининградской области по показателю сложности продукции (PCI) и плотности компетенций (ICD) дана на рисунке 5.

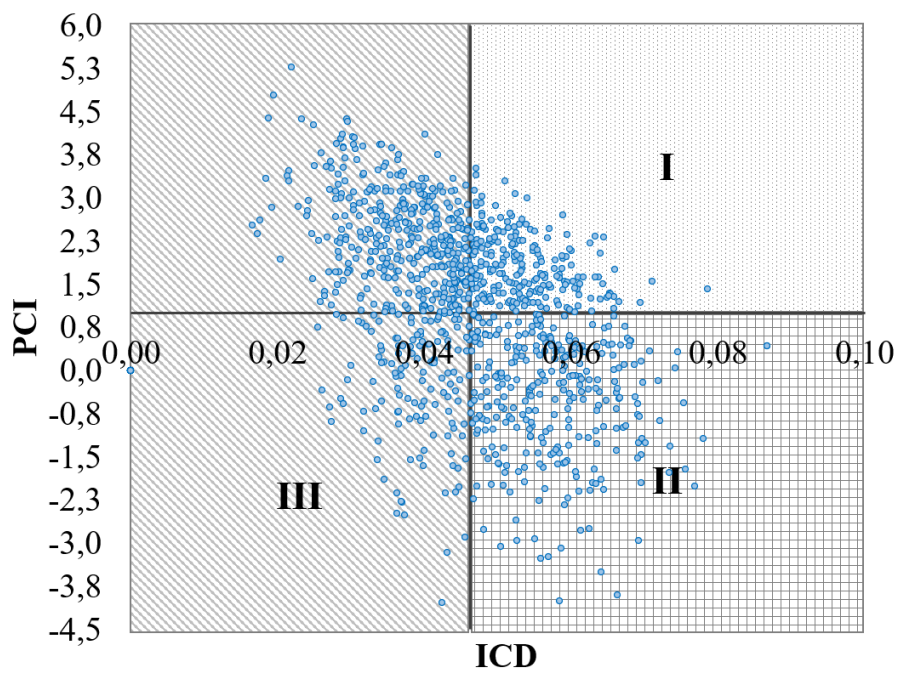

Р и с. 5. Измерение продуктового пространства на основе PCI и ICD

F i g. 5. Product opportunity space plotted on the PCI (Product Complexity Index) and ICD (Implied Capability Density) dimensions 
Для анализа представленной информации необходимо принимать во внимание следующее: чем выше PCI, тем больше возможность для производства новых сложных продуктов, а чем выше ICD, тем выше доля существующих в экономике компетенций, необходимых для их производства. В зависимости от значений PCI и ICD образуются три квадранта: «I - категории продуктов, на которых должен сфокусироваться регион; II - регион получает незначительные выгоды, так как ценность от производства новых более сложных продуктов меньше 1; III - для этих категорий продуктов нет достаточных компетенций и/или их выпуск не будет способствовать росту абсорбционных способностей региона» [26, с. 172].

Большая часть продукции, производимой в Калининградской области, по показателям сложности попадает во II и III квадранты. Обнаруживается низкий уровень минимальной плотности компетенций (ICD) для получения сравнительного преимущества (RCA больше 1). Его средневзвешенное значение составляет только 4,6 \% (справочно: в среднем по России $-10,1 \%$, у большинства развитых экономик - более 20,0 \%). Основная причина связана с тем, что организации зависят от передаваемых, импортируемых или представленных по лицензии производственных компетенций, которые формируются за пределами, а не внутри региона.

Результаты анализа экономической сложности свидетельствуют о необходимости увеличения внутренней базы производственных возможностей Калининградской области. Однако происходящие изменения в регионе в результате роста экономической сложности могут оказывать негативное влияние на состояние и развитие производств, отраслей, секторов, которые важны с точки зрения обеспечения экономической безопасности. Указанная проблема может в определенных границах оперативно решаться в рамках интенсификации межрегиональных торговых отношений. Однако долгосрочное видение и стратегия роста региона требуют учета взаимообусловленности экономической безопасности и сложности. Для этих целей нами разработаны методические положения для анализа обеспечения экономической безопасности приграничного региона с учетом выбора направлений роста его экономической сложности (рис. 6).

На первом этапе проводится подготовка исходной базы данных для оценки экономической сложности и последующей отраслевой приоритизации. На втором этапе осуществляется расчет показателей экономической сложности и производных метрик: выявленное сравнительное преимущество (RCA), индекс экономической сложности (ECI), продуктовая сложность (PCI), потенциал усложнения экономики (OV и COI), относительная потенциальная выгода (OG и COG). На третьем этапе проводится анализ полученных показателей, оценивается продуктовое пространство региона, выявляются ключевые производства и отрасли с точки зрения выпуска сложной продукции. Далее проводится моделирование и прогнозирование 
уровня экономической безопасности, где отражаются ключевые стратегические решения и новые приоритеты в развитии региона. На основе прогнозных макроэкономических показателей измеряется уровень экономической безопасности. Делается вывод о возможных направлениях роста экономической сложности, которые способствуют укреплению позиций региона по экономической безопасности.

С учетом результатов, полученных в монографии под редакцией $Г$. М. Федорова $^{17}$, нами дополнительно проведено моделирование экономической безопасности Калининградской области в границах экономической сложности с использованием ситуационного прогнозирования и стратегирования ${ }^{18}$ (рис. 7). Оценивался сценарий, который характеризует ускоренное социально-экономическое развитие региона посредством усложнения экономики для достижения порогового уровня экономической безопасности. Выявлено, что внутреннего потенциала даже при наиболее вероятном активном развитии производственных возможностей будет недостаточно для достижения порогового уровня экономической безопасности. Регион остается в зоне умеренного риска.

Обсуждение и заключение. Результаты проведенного исследования доказывают необходимость изучения экономической безопасности региона с учетом пространственно-территориальных особенностей во взаимосвязи с экономической сложностью.

При этом в отношении приграничных регионов, что подтверждается как результатами оценки и моделирования экономической безопасности на примере Калининградской области, так и анализом других регионов Западного порубежья России ${ }^{19}$, обнаруживается ситуация, когда пороговый уровень экономической безопасности не достигается в силу наличия системных ограничений. Таким образом, можно сделать вывод об отсутствии абсолютной экономической безопасности и пороговых значений даже в пределах одного типа регионов, попытки по разработке которых предпринимаются на протяжении последних лет многими учеными. Необходимо вести речь только о приближении территории к уровню экономической безопасности, соответствующего границе риска нанесения минимального ущерба при условии использования внутреннего потенциала и ресурсов, а также внешних возможностей. В отношении выявления последних в настоящей работе установлена связь и обусловленность с экономической сложностью.

Поэтому в развитии регионов необходимо учитывать следующие положения изучения экономической безопасности в границах экономической сложности.

17 Западное порубежье России: моделирование развития и обеспечение экономической безопасности: моногр. / Г. М. Федоров [и др.]. Калининград: Изд-во БФУ им. И. Канта, 2020. 319 с.

${ }^{18}$ Свидетельство о госрегистрации программы для ЭВМ № 2016617454 от 06 июля 2016 г., авторы: Волошенко К. Ю., Цыбатов В. А., Павлов Л. П.

19 Западное порубежье России: моделирование развития и обеспечение экономической безопасности: моногр. / Г. М. Федоров [и др.]. Калининград, 2020. 


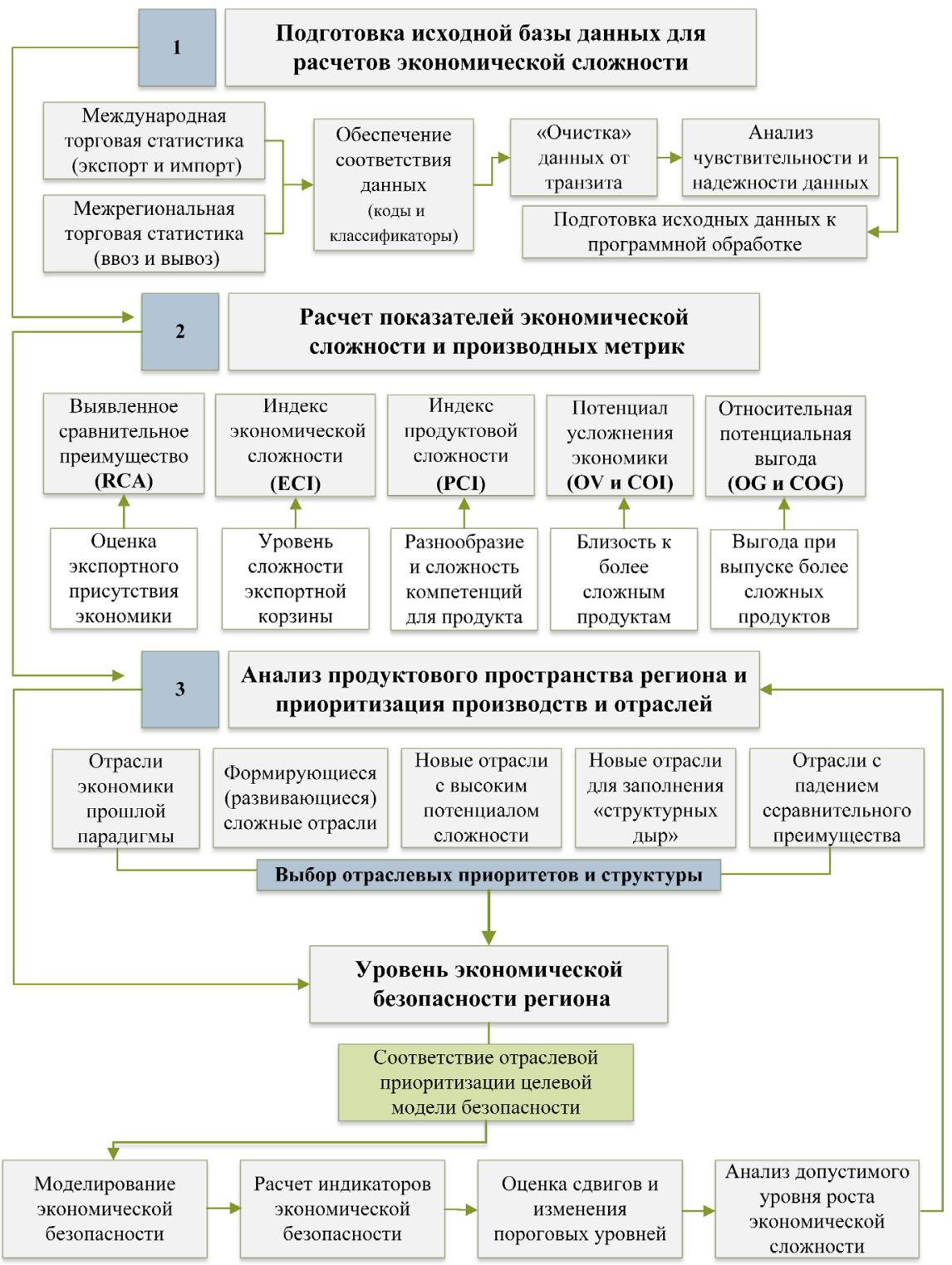

Р и с. 6. Анализ экономической безопасности в границах экономической сложности 


\section{Preparation of the source database to calculate} the economic complexity
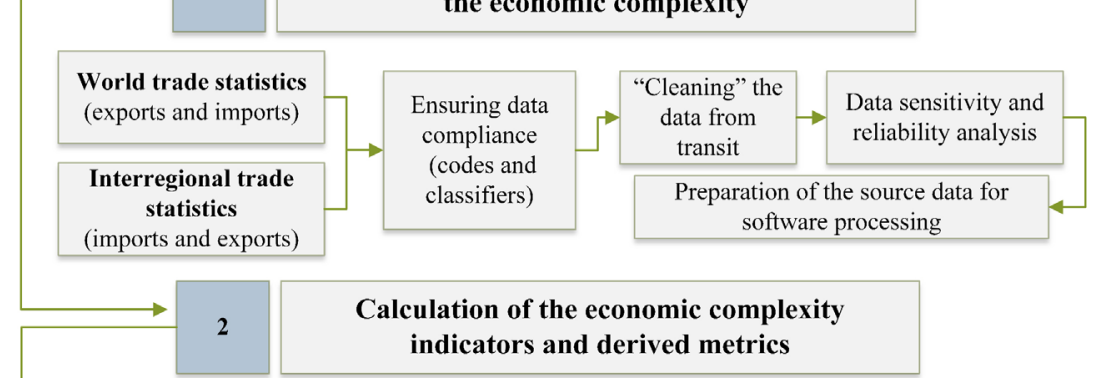

\section{Calculation of the economic complexity indicators and derived metrics}
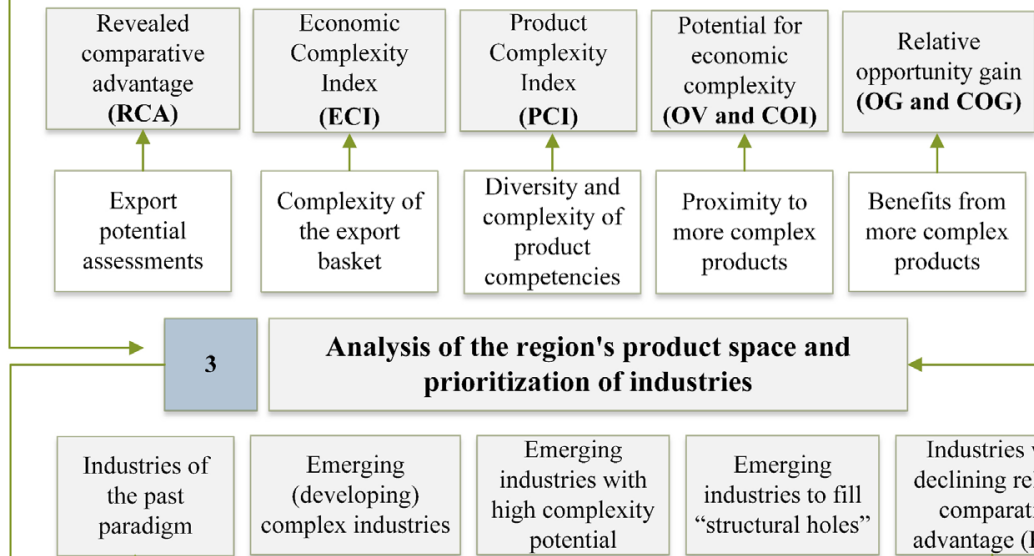

Industries with declining relative comparative advantage (RCA)

\section{of the region's product space and prioritization of industries}

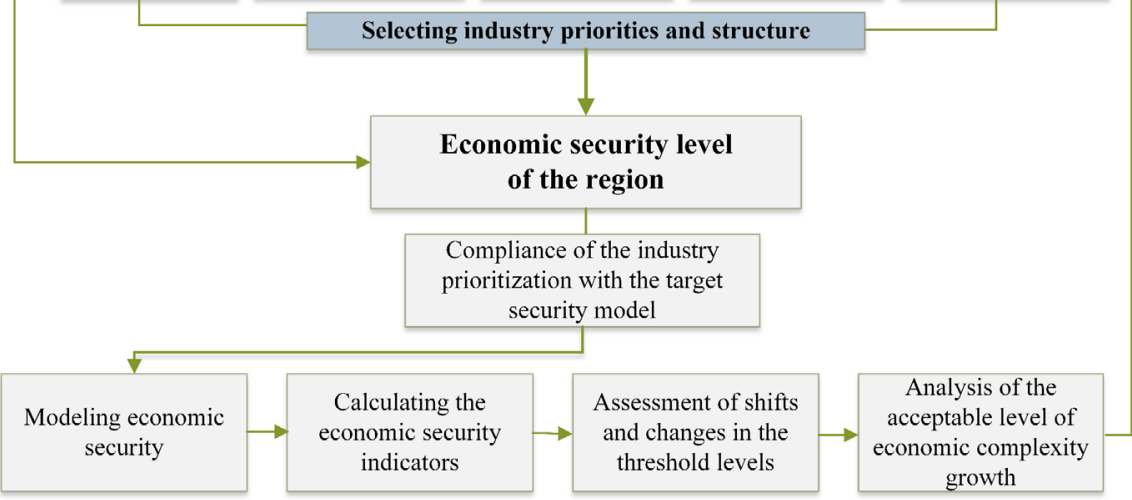

F i g. 6. Analysis of economic security within the limits of economic complexity 


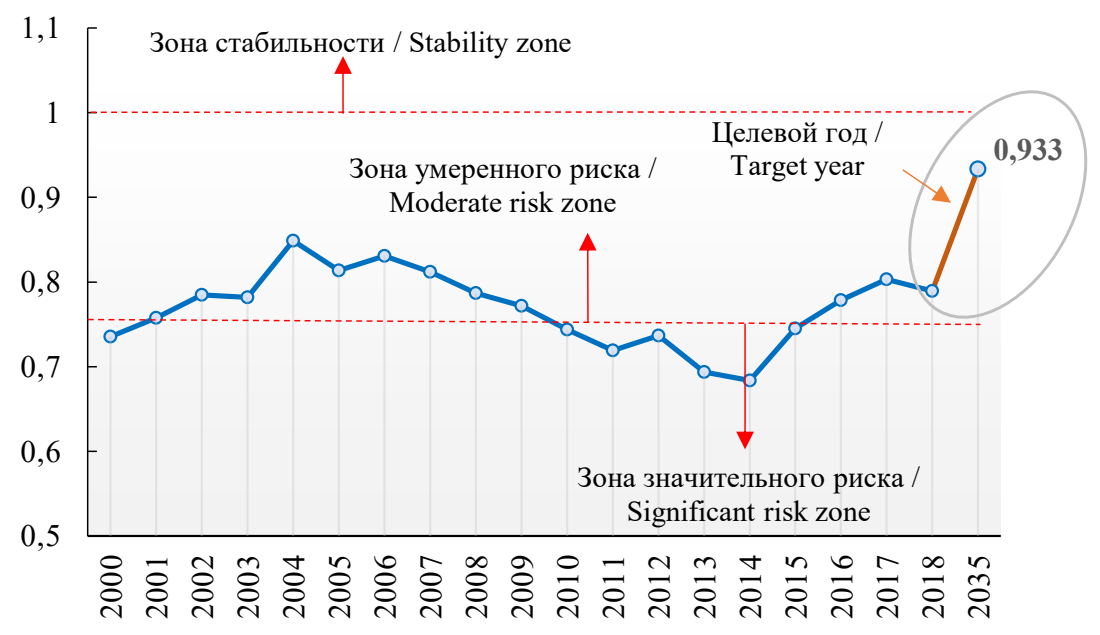

Р и с. 7. Динамика интегрального индекса экономической безопасности

F i g. 7. Dynamics of the integral index of economic security

Во-первых, анализ экономической сложности региона позволяет оценить его позиции в мировом продуктовом пространстве и измерить достаточность компетенций для роста разнообразия и сложности продукции. С учетом интересов обеспечения экономической безопасности на этой основе прорабатываются ключевые направления развития региона, в том числе в рамках отраслевой структурной трансформации.

Во-вторых, экономическая безопасность региона не может быть обеспечена независимо от экономической сложности. Выбор внутреннего или внешнего векторов развития определяется с учетом специфических условий и факторов развития конкретного региона, характеристик его внутреннего потенциала и ресурсов с точки зрения возможностей их использования в присутствии рисков экономического развития.

В-третьих, модель экономической безопасности региона формируется в границах экономической сложности. Состояние защищенности от внешних и внутренних угроз достигается за счет накопления новых знаний и компетенций, а также с учетом развития и абсорбционных способностей региона.

Разработанные в исследовании механизм и критерии, а также методические положения выбора между поддержанием уровня экономической безопасности или ростом экономической сложности имеют важное значение с практической точки зрения при формировании ключевых направлений структурной трансформации экономики региона. Это позволяет решить 
актуальную задачу для региональных органов государственной власти в области отраслевой приоритизации промышленной политики. В целом полученные новые результаты важны и с позиций дальнейшего развития теории экономической безопасности и экономической сложности на региональном уровне.

\section{СПИСОК ИСПОЛЬЗОВАННЫХ ИСТОЧНИКОВ}

1. Волошенко, Е. В. Оценка и измерение экономической безопасности приграничных регионов России: теория и практика / Е. В. Волошенко, К. Ю. Волошенко. - DOI 10.5922/2079-8555-2018-3-6 // Балтийский регион. - 2018. - Т. 10, № 3. C. 96-118. - URL: https://journals.kantiana.ru/baltic_region/4018/11459/ (дата обращения: 15.02.2021). - Рез. англ.

2. Волошенко, К. Ю. Экономическая сложность на субнациональном уровне инновационная парадигма регионального развития / К. Ю. Волошенко, Т. Е. Дрок, Ю. Ю. Фарафонова. - DOI 10.18334/vinec.9.3.40822 // Вопросы инновационной экономики. - 2019. - Т. 9, № 3. - C. 735-752. - URL: https://1economic.ru/lib/40822 (дата обращения: 15.02.2021). - Рез. англ.

3. Межевич, Н. М. Приграничное сотрудничество: новое положение в системе факторов регионального развития Северо-Запада России / Н. М. Межевич, С. А. Ткачев // Корпоративное управление и инновационное развитие экономики Севера: Вестник Научно-исследовательского центра корпоративного права, управления и венчурного инвестирования Сыктывкарского государственного университета. - 2017. № 1. - C. 69-74. - URL: http://vestnik-ku.ru/ru/arkhiv/2017-rus/vestnik-1-2017-rus/15publikatsii/197-prigranichnoe-sotrudnichestvo-novoe-polozhenie-v-sisteme-faktorovregionalnogo-razvitiya-severo-zapada-rossii (дата обращения: 15.02.2021). - Рез. англ.

4. Демьяненко, А. Н. Экономическое пространство Дальнего Востока: посткризисная динамика и экономическая безопасность / А. Н. Демьяненко, О. М. Прокапало. DOI 10.14530/reg.2018.5.25 // Регионалистика. - 2018. - T. 5, № 5. - С. 25-32. - URL: http://regionalistica.org/archive/20-2018/2018-5/127-reg-2018-5-3-rus (дата обращения: 15.02.2021). - Рез. англ.

5. Котилко, В. В. Конкурентоспособность и экономическая безопасность приграничных регионов: реалии и перспективы / В. В. Котилко, Г. И. Немирова, Ф. С. Пашенных // Национальные интересы: приоритеты и безопасность. - 2013. - Т. 9, № 46. C. 2-7. - URL: https://www.fin-izdat.ru/journal/national/detail.php?ID=59721 (дата обращения: 15.02.2021). - Рез. англ.

6. Nepelski, D. Corporate Control, Location and Complexity of ICT R\&D: A Network Analysis at the City Level / D. Nepelski, G. De Prato. - DOI 10.1177/0042098014534735 // Urban Studies. - 2015. - Vol. 52, issue 4. - Pp. 721-737. - URL: https://journals.sagepub. com/doi/10.1177/0042098014534735 (дата обращения: 15.02.2021).

7. Balland, P.-A. The Geography of Complex Knowledge / P.-A. Balland, D. Rigby. DOI 10.1080/00130095.2016.1205947 // Economic Geography. - 2017. - Vol. 93, issue 1. Pp. 1-23. - URL: https://www.tandfonline.com/doi/full/10.1080/00130095.2016.1205947 (дата обращения: 15.02.2021). 
8. Buccellato, T. Structural Change and Convergence Across European Regions / T. Buccellato, G. Corò. - DOI 10.2139/ssrn.3197017. - University Ca' Foscari of Venice, Dept. of Economics Research Paper Series № 16. - 2018. - 22 p. - URL: https://papers.ssrn. com/sol3/Delivery.cfm/SSRN_ID3197017_code576529.pdf?abstractid=3197017\&mirid=1 (дата обращения: 15.02.2021).

9. Reynolds, C. A. Sub-National Economic Complexity Analysis of Australia's States and Territories / C. Reynolds, M. Agrawal, I. Lee [et al.]. - DOI 10.1080/00343404.2017.1 283012 // Regional Studies. - 2018. - Vol. 52, issue 5. - Pp. 715-726. - URL: https://www. tandfonline.com/doi/abs/10.1080/00343404.2017.1283012 (дата обращения: 15.02.2021).

10. Roos, G. Smart Specialisation - Insights for a Future Industry Policy. Economic Development Board of South Australia - Main Report / G. Roos, Z. Shroff, H. Gamble [et. al]. - DOI 10.13140/RG.2.2.25616.92168. - Government of South Australia. Adelaide, South Australia. - 2018. - 68 p. - URL: http://nla.gov.au/anbd.aut-an35319270 (дата обращения: 13.02.2021).

11. Gao, J. Quantifying China's Regional Economic Complexity / J. Gao, T. Zhou. DOI 10.1016/j.physa.2017.11.084 // Physica A: Statistical Mechanics and its Applications. 2018. - Vol. 492. - Pp. 1591-1603. - URL: https://www.sciencedirect.com/science/article/ abs/pii/S0378437117311378 (дата обращения: 13.02.2021).

12. Bandeira Morais, M. Economic Complexity and Inequality: Does Regional Productive Structure Affect Income Inequality in Brazilian States? / M. Bandeira Morais, J. Swart, J. A. Jordaan. - DOI 10.3390/su13021006 // Sustainability. - 2021. - Vol. 13, issue 2. URL: https:/www.mdpi.com/2071-1050/13/2/1006 (дата обращения: 13.02.2021).

13. Lee, I. Economic Complexity of the City Cluster in Guangdong-Hong Kong-Macao Greater Bay Area, China / I. Lee, R.F.-Y. Lin. - DOI 10.3390/su12145639 // Sustainability. - 2020. - Vol. 12, issue 4.- URL: https://www.mdpi.com/2071-1050/12/14/5639 (дата обращения: 13.02.2021).

14. Roos, G. What will Happen to the Jobs? Technology Enabled Productivity Improvement - Good for Some, Bad for Others / G. Roos, Z. Shroff. - DOI 10.1080/10301763.2017. 1359817 // Labour \& Industry: A Journal of the Social and Economic Relations of Work. 2017. - Vol. 27, issue 3. - Pp. 165-192. - URL: https://www.tandfonline.com/doi/abs/10.1 080/10301763.2017.1359817 (дата обращения: 13.02.2021).

15. Sweet, C. Do Patent Rights Matter? 40 Years of Innovation, Complexity and Productivity / C. Sweet, D. Eterovic. - DOI 10.1016/j.worlddev.2018.10.009 // World Development. - 2019. - Vol. 115. - Pp. 78-93. - URL: https://www.sciencedirect.com/science/ article/abs/pii/S0305750X18303954 (дата обращения: 13.02.2021).

16. Díaz-Lanchas, J. Cities Export Specialization / J. Díaz-Lanchas, C. Llano, A. Minondo, F. Requena. - DOI 10.1080/13504851.2017.1290784 // Applied Economics Letters. 2018. - Vol. 25, issue 1. - Pp. 38-42. - URL: https://www.tandfonline.com/doi/abs/10.108 0/13504851.2017.1290784 (дата обращения: 13.02.2021).

17. Hartmann, D. International Trade, Development Traps, and the Core-Periphery Structure of Income Inequality / D. Hartmann, M. Bezerra, B. Lodolo, F. L. Pinheiro. - DOI 10.2139/ssrn.3312097. - Stuttgart: University of Hohenheim, 2019. - 37 p. - URL: https:// papers.ssrn.com/sol3/papers.cfm?abstract_id=3312097 (дата обращения: 13.02.2021).

18. Hidalgo, C. A. The Principle of Relatedness / C. A. Hidalgo, P.-A. Balland, R. Boschma [et. al]. - DOI 10.1007/978-3-319-96661-8 46 // Unifying Themes in Complex Systems IX / A. Morales, C. Gershenson, D. Braha [et al.]. Springer, Cham., 2018. - 
Pp 451-457. - URL: https://link.springer.com/chapter/10.1007/978-3-319-96661-8_46\#citeas (дата обращения: 13.02.2021).

19. Любимов, И. Л. Как сделать экономику сложнее? Поиск причин усложнения / И. Л. Любимов, А. Г. Оспанова. - DOI 10.32609/0042-8736-2019-2-36-53 // Вопросы экономики. - 2019. - № 2. - C. 36-53. - URL: https://www.vopreco.ru/jour/article/ view/2142 (дата обращения: 13.02.2021). - Рез. англ.

20. Любимов, И. Л. Структурная трансформация и отраслевая производительность: учет направлений экспорта в индексе экономической сложности / И. Л. Любимов, И. В. Якубовский. - DOI 10.31737/2221-2264-2020-47-3-1 // Журнал новой экономической ассоциации. - 2020. - № 3 (47). - C. 12-39. - URL: http://www.econorus.org/ repec/journl/2020-47-12-39r.pdf (дата обращения: 13.02.2021). - Рез. англ.

21. Кадочников, С. М. Динамика экспортной диверсификации в условиях экономического роста: эмпирический анализ для российских регионов 2003-2010 гг. / С. М. Кадочников, А. А. Федюнина // Вестник Уральского федерального университета. - 2013. - № 5. - С. 73-89. - URL: https://elar.urfu.ru/handle/10995/55011 (дата обращения: 13.02.2021).

22. Кравченко, Н. А. Диверсификация экономики: институциональные аспекты / Н. А. Кравченко, С. Д. Агеева. - DOI 10.17835/2076-6297.2017.9.4.052-067 // Journal of Institution Studies. - 2017. - № 4. - C. 52-67. - URL: http://www.hjournal.ru/en/journals/ journal-of-institutional-studies/2017/186-no-4/1593-diversification-of-the-economyinstitutional-aspects.html (дата обращения: 13.02.2021). - Рез. англ.

23. Любимов, И. Л. Сложность экономики и возможность диверсификации экспорта в российских регионах / И. Л. Любимов, М. А. Гвоздева, М. В. Казакова, К. В. Нестерова. - DOI 10.31737/2221-2264-2017-34-2-4 // Журнал Новой экономической ассоциации. - 2017. - № 2 (34). - C. 94-123. - URL: http://journal.econorus.org/pdf/NEA-34. pdf (дата обращения: 13.02.2021). - Рез. англ.

24. Любимов, И. Л. Атлас экономической сложности российских регионов / И. Л. Любимов, М. В. Лысюк, М. А. Гвоздева. - DOI 10.32609/0042-8736-2018-671-91 // Вопросы экономики. - 2018. - № 6. - C. 71-91. - URL: https://www.vopreco.ru/ jour/article/view/411 (дата обращения: 13.06.2019).

25. Волошенко, К. Ю. Эконометрический анализ влияния интенсивности трансграничности на уровень экономической сложности на примере стран Европы / К. Ю. Волошенко, Т. Е. Дрок. - DOI 10.15507/2413-1407.109.027.201904.602-632 // Peгионология. - 2019. - Т. 27, № 4. - С. 602-631. - URL: http://regionsar.ru/ru/node/1810 (дата обращения: 13.06.2019). - Рез. англ.

26. Анализ экономической сложности Калининградской области - выбор отраслевых приоритетов в новой парадигме создания ценности / Й. Руус, К. Ю. Волошенко, Т.Е.Дрок, Ю. Ю. Фарафонова. - DOI 10.5922/2079-8555-2020-1-9 // Балтийский регион. - 2020. - Т. 12, № 1. - С. 156-180. - URL: https://journals.kantiana.ru/baltic_ region/4416/13003/ (дата обращения: 13.06.2019). - Рез. англ.

27. Roos G. European Countries' Typology by the Intensity of Transboundary Cooperation and its Impact on the Economic Complexity Level / G. Roos, K. Yu. Voloshenko, T. E. Drok, Y. M. Zverev. - DOI 10.24057/2071-9388-2019-66 // Geography, Environment, Sustainability. Special issue: «Border and Coastal Areas of Greater Eurasia: Environmental and Socio-economic Challenges». - 2020. - Vol. 13, no. 1. - Pp. 6-15. - URL: https://ges. rgo.ru/jour/article/view/1020 (дата обращения: 13.06.2019). 
28. Callon, M. Co-word Analysis as a Tool for Describing the Network of Interaction between Basic and Technological Research: The Case of Polymer Chemistry / M. Callon, J. P. Courtial, F. Laville. - DOI 10.1007/BF02019280 // Scientometrics. - 1991. - Vol. 22. - Pp. 155-205. URL: https://link.springer.com/article/10.1007\%2FBF02019280 (дата обращения: 13.06.2019).

29. Hidalgo, C. A. The Building Blocks of Economic Complexity / C. A. Hidalgo, R. Hausmann. - DOI 10.1073/pnas.0900943106 // PNAS. - 2009. - № 106 (26). - Pp. 10570-10575. URL: https://www.pnas.org/content/106/26/10570 (дата обращения: 15.02.2021).

Поступила 19.02.2021; одобрена после рецензирования 23.03.2021; принята к публикации 31.03.2021.

Об авторе:

Волошенко Ксения Юрьевна, директор центра социально-экономических исследований региона ФГАОУ ВО «Балтийский федеральный университет имени Иммануила Канта» (236016, Российская Федерация, г. Калининград, ул. А. Невского, д. 14), кандидат экономических наук, доцент, ORCID: https:/orcid.org/0000-0002-2624-0155, kvoloshenko@kantiana.ru

Автор прочитал и одобрил окончательный вариант рукописи.

\section{REFERENCES}

1. Voloshenko E.V., Voloshenko K.Yu. Evaluating and Measuring the Security of Russia's Border Regions: Theory and Practice. Baltijskij region = Baltic Region. 2018; 10(3):96-118. (In Russ., abstract in Eng.) DOI: https://doi.org/10.5922/2079-8555-2018-3-6

2. Voloshenko K.Yu., Drok T.E., Farafonova Yu.Yu. The Economic Complexity at the Sub-National Level as an Innovative Paradigm for Regional Development. Voprosy innovacionnoj ehkonomiki = Russian Journal of Innovation Economics. 2019; 9(3):735-752. (In Russ., abstract in Eng.) DOI: https://doi.org/10.18334/vinec.9.3.40822

3. Mezhevich N.M., Tkachev S.A. Cross-border Cooperation: A New Position in System of Factors of Regional Development of the North-West Russia. Korporativnoe upravlenie i innovacionnoe razvitie jekonomiki Severa: Vestnik Nauchno-issledovatelskogo centra korporativnogo prava, upravlenija i venchurnogo investirovanija Syktyvkarskogo gosudarstvennogo universiteta $=$ Corporate Governance and Innovative Economic Development of the North. Bulletin of Research Center of Corporate Law, Management and Venture Investment of Syktyvkar State University. 2017; (1):69-74. Available at: http://vestnik-ku.ru/ru/ arkhiv/2017-rus/vestnik-1-2017-rus/15-publikatsii/197-prigranichnoe-sotrudnichestvo-novoe-polozhenie-v-sisteme-faktorov-regionalnogo-razvitiya-severo-zapada-rossii (accessed 15.02.2021). (In Russ., abstract in Eng.).

4. Demyanenko A.N., Prokapalo O.M. Economic Space of the Russian Far East: Post-Crisis Dynamics and Economic Security. Regionalistika = Regionalistica. 2018; 5(5):25-32. (In Russ., abstract in Eng.) DOI: https://doi.org/10.14530/reg.2018.5.25

5. Kotilko V.V., Nemirova G.I., Pashennykh F.S. Competitiveness and Economic Safety of Frontier Regions: Realities and Prospects. Nacionalnye interesy: prioritety $i$ bezopasnost $=$ 
National Interests: Priorities and Security. 2013; 9(46):2-7. Available at: https://www.fin-izdat. $\mathrm{ru} /$ journal/national/detail.php? ID=59721 (accessed 15.02.2021). (In Russ., abstract in Eng.)

6. Nepelski D., De Prato G. Corporate Control, Location and Complexity of ICT R\&D: A Network Analysis at the City Level. Urban Studies. 2015; 52(4):721-737. (In Eng.) DOI: https://doi.org/10.1177/0042098014534735

7. Balland P.-A., Rigby D. The Geography of Complex Knowledge. Economic Geography. 2017; 93(1):1-23. (In Eng.) DOI: https://doi.org/10.1080/00130095.2016.1205947

8. Buccellato T., Corò G. Structural Change and Convergence Across European Regions. University Ca' Foscari of Venice. 2018. (In Eng.) DOI: https://doi.org/10.2139/ssrn.3197017

9. Reynolds C.A., Agrawal M., Lee I., et al. Sub-National Economic Complexity Analysis of Australia's States and Territories. Regional Studies. 2018; 52(5):715-726. (In Eng.) DOI: https://doi.org/10.1080/00343404.2017.1283012

10. Roos G., Shroff Z., Gamble H., et al. Smart Specialisation - Insights for a Future Industry Policy. Economic Development Board of South Australia. Government of South Australia. Adelaide, South Australia; 2018. (In Eng.) DOI: https://doi.org/10.13140/ RG.2.2.25616.92168

11. Gao J., Zhou T. Quantifying China's Regional Economic Complexity. Physica A: Statistical Mechanics and its Applications. 2018; 492:1591-1603. (In Eng.) DOI: https://doi. org/10.1016/j.physa.2017.11.084

12. Bandeira Morais M., Swart J., Jordaan J.A. Economic Complexity and Inequality: Does Regional Productive Structure Affect Income Inequality in Brazilian States? Sustainability. 2021; 13(2). (In Eng.) DOI: https://doi.org/10.3390/su13021006

13. Lee I., Lin R.F.-Y. Economic Complexity of the City Cluster in Guangdong-Hong Kong-Macao Greater Bay Area, China. Sustainability. 2020; 12(4). (In Eng.) DOI: https:// doi.org/10.3390/su12145639

14. Roos G., Shroff Z. What Will Happen to the Jobs? Technology Enabled Productivity Improvement - Good for Some, Bad for Others. Labour \& Industry: A Journal of the Social and Economic Relations of Work. 2017; 27(3):165-192. (In Eng.) DOI: https://doi.org/10.1 080/10301763.2017.1359817

15. Sweet C., Eterovic D. Do Patent Rights Matter? 40 Years of Innovation, Complexity and Productivity. World Development. 2019; 115:78-93. (In Eng.) DOI: https://doi. org/10.1016/j.worlddev.2018.10.009

16. Díaz-Lanchas J., Llano C., Minondo A., Requena F. Cities Export Specialization. Applied Economics Letters. 2018; 25(1):38-42. (In Eng.) DOI: https://doi.org/10.1080/135 04851.2017 .1290784

17. Hartmann D., Bezerra M., Lodolo B., Pinheiro F.L. International Trade, Development Traps, and the Core-Periphery Structure of Income Inequality. Stuttgart: University of Hohenheim; 2019. (In Eng.) DOI: https://doi.org/10.2139/ssrn.3312097

18. Hidalgo C.A., Balland P.-A., Boschma R., et al. The Principle of Relatedness. In: Unifying Themes in Complex Systems IX. Springer Proceedings in Complexity. Springer, Cham; 2018. p. 451-457. (In Eng.) DOI: https://doi.org/10.1007/978-3-319-96661-8_46

19. Lyubimov I.L., Ospanova A.G. How to Make an Economy More Complex? The Determinants of Complexity in Historical Perspective. Voprosy ehkonomiki = Issues of Economics. 2019; (2):36-53. (In Russ., abstract in Eng.) DOI: https://doi.org/10.32609/00428736-2019-2-36-53 
20. Lyubimov I.L., Iakubovskii I.G. How to Make Economic Complexity Index More Complex: Taking Export Geography into Account. Zhurnal Novoj ehkonomicheskoj assotsiatsii $=$ The Journal of the New Economic Association. 2020; (3):12-39. (In Russ., abstract in Eng.) DOI: https://doi.org/10.31737/2221-2264-2020-47-3-1

21. Kadochnikov S.M., Fedyunina A.A. The Dynamics of Export Diversification and Economic Growth: Empirical Analysis for Russian Regions, 2003-2010. Vestnik Uralskogo federalnogo universiteta $=$ Bulletin of Ural Federal University. 2013; (5):73-89. Available at: https://elar.urfu.ru/handle/10995/55011 (accessed: 13.02.2021). (In Russ.)

22. Kravchenko N.A., Ageeva S.D. Diversification of the Economy: Institutional Aspects. Journal of Institutional Studies. 2017; (4):52-67. (In Russ., abstract in Eng.) DOI: https://doi.org/10.17835/2076-6297.2017.9.4.052-067

23. Lyubimov I.L., Gvozdeva M.A., Kazakova M.V., Nesterova K.V. Economic Complexity of Russian Regions and their Potential to Diversify. Zhurnal Novoj ehkonomicheskoj assotsiatsii $=$ The Journal of the New Economic Association. 2017; (2):94-123. (In Russ., abstract in Eng.) DOI: https://doi.org/10.31737/2221-2264-2017-34-2-4

24. Lyubimov I.L., Lysyuk M.V., Gvozdeva M.A. Atlas of Economic Complexity, Russian Regional Pages. Voprosy ehkonomiki = Issues of Economics. 2018; (6):71-91. (In Russ., abstract in Eng.) DOI: https://doi.org/10.32609/0042-8736-2018-6-71-91

25. Voloshenko K.Yu., Drok T.E. Econometric Analysis of the Impact of the Intensity of Transboundary Activities on the Level of Economic Complexity: The Case Study of European Countries. Regionology = Russian Journal of Regional Studies. 2019; 27(4):602-632. (In Russ., abstract in Eng.) DOI: https://doi.org/10.15507/2413-1407.109.027.201904.602-632

26. Roos G., Voloshenko K. Yu., Drok T.E., Farafonova Yu. Yu. An Economic Complexity Analysis of the Kaliningrad Region: Identifying Sectoral Priorities in the Emerging Value Creation Paradigm. Baltijskij region = Baltic Region. 2020; 12(1):156-180. (In Russ., abstract in Eng.) DOI: https://doi.org/10.5922/2079-8555-2020-1-9

27. Roos G., Voloshenko K.Yu., Drok T.E., Zverev Y.M. European Countries' Typology by the Intensity of Transboundary Cooperation and its Impact on the Economic Complexity Level. Geography, Environment, Sustainability. Special issue: "Border and Coastal Areas of Greater Eurasia: Environmental and Socio-Economic Challenges". 2020; 13(1):6-15. (In Eng.) DOI: https://doi.org/10.24057/2071-9388-2019-66

28. Callon M., Courtial J.P., Laville F. Co-Word Analysis as a Tool for Describing the Network of Interaction between Basic and Technological Research: The Case of Polymer Chemistry. Scientometrics. 1991; 22:155-205. (In Eng.) DOI: https://doi.org/10.1007/BF02019280

29. Hidalgo C.A., Hausmann R. The Building Blocks of Economic Complexity. PNAS. 2009; (106):10570-10575. (In Eng.) DOI: https://doi.org/10.1073/pnas.0900943106

Submitted 19.02.2021; approved after reviewing 23.03.2021; accepted for publication 31.03.2021.

About the author:

Ksenia Yu. Voloshenko, Director, Center for Regional Socio-Economic Research, Immanuel Kant Baltic Federal University (14 A. Nevskogo St., Kaliningrad 236016, Russian Federation), Cand. Sci. (Economics), Associate Professor, ORCID: https://orcid.org/00000002-2624-0155, kvoloshenko@kantiana.ru

The author has read and approved the final version of the manuscript. 
СОЦИАЛЬНАЯ СТРУКТУРА, СОЦИАЛЬНЫЕ ИНСТИТУТЫ И ПРОЦЕССЫ / SOCIAL STRUCTURE, SOCIAL INSTITUTIONS AND PROCESSES

УДК 331.52(470+571)

DOI: $10.15507 / 2413-1407.115 .029 .202102 .427-446$

Оригинальная статья / Original article http://regionsar.ru

ISSN 2587-8549 (Print)

ISSN 2413-1407 (Online)

\section{Долгосрочные тенденции региональных рынков труда в России}

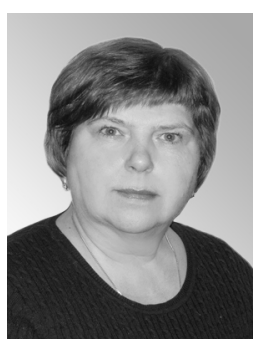

\author{
А. Е. Курило \\ Институт экономики - обособленное подразделение \\ Федерального исследовательского иентра "Карельский \\ научный иентр Российской академии наук» \\ (2. Петрозаводск, Российская Федераиия), \\ akurilo@mail.ru
}

нах Российской Федерации.

Введение. Безработица является одним из фундаментальных вопросов макроэкономики и оказывает существенное влияние на социально-экономическое развитие регионов и страны в целом. Цель статьи - по результатам проведенного исследования определить взаимосвязи безработицы и объемов производства в регио-

Материалы и методы. В работе использованы открытые статистические данные по 79 субъектам Российской Федерации. Для выявления тенденций развития региональных рынков труда применялись методы компаративного, экономического и статистического анализа. На основе экономико-статистических данных российских регионов за 1997-2017 гг. исследованы тенденции рынка труда, включая взаимосвязи валового регионального продукта и уровня безработицы.

Результаты исследования. Определено усиление расхождения агрегированных показателей рынка труда - уровня зарегистрированной безработицы и уровня безработицы по материалам проведения выборочных обследований населения. Представлена инертность показателя «уровень зарегистрированной безработицы», связанная с институциональными ограничениями рынка труда. Выявлена слабая реакция валового регионального продукта на изменение агрегированных показателей безработицы. Не наблюдается четкая закономерность выполнения взаимосвязи объемов выпуска и изменения уровня безработицы согласно методологии Международной организации труда по данным выборочных обследований рабочей силы.

Обсуждение и заключение. Усиление расхождения агрегированных показателей безработицы свидетельствует об искажении формальной институциональной среды рынка труда и обусловлено финансовыми ограничениями органов власти. Дальнейшие исследования будут направлены на определение влияния отраслевой структуры экономики на тесноту связи изменения валового регионального продукта и агрегированных

(C) Курило А. Е., 2021

Контент доступен под лицензией Creative Commons Attribution 4.0 License. This work is licensed under a Creative Commons Attribution 4.0 License. 
индикаторов рынка труда. Понимание тенденций развития рынка труда необходимо для проведения взвешенной политики управления его трансформацией и социальноэкономическим развитием регионов и страны в целом.

Ключевые слова: уровень безработицы, валовой региональный продукт, закон Оукена, регрессионная модель, экономический рост

Автор заявляет об отсутствии конфликта интересов.

Финансирование. Статья подготовлена в рамках государственного задания Института экономики Карельского научного центра РАН, тема НИР «Выявление синергетических закономерностей региональных социо-эколого-экономических систем и моделирование динамических процессов устойчивого развития в многокомпонентных системах различной природы».

Благодарности. Автор выражает благодарность рецензентам, чьи комментарии позволили улучшить качество статьи.

Для иитирования: Курило, А. Е. Долгосрочные тенденции региональных рынков труда в России / А. Е. Курило. - DOI 10.15507/2413-1407.115.029.202102.427-446 // Регионология. - 2021. - Т. 29, № 2. - С. 427-446.

\title{
Long-Term Trends in Regional Labor Markets in Russia
}

\author{
A. E. Kurilo \\ Institute of Economics, Karelian Research Centre of the Russian Academy of Sciences \\ (Petrozavodsk, Russian Federation), \\ akurilo@mail.ru
}

Introduction. Unemployment is one of the fundamental issues of macroeconomics and has a significant impact on the socio-economic development of regions and the country as a whole. Based on the results of the conducted study, the article identifies the correlation between unemployment and volumes of output in the regions of the Russian Federation.

Materials and Methods. The paper used open statistical data for 79 constituent entities of the Russian Federation. The methods of comparative, economic, and statistical analysis were used to identify the trends in the development of regional labor markets. The trends of the labor market, including the correlation between the gross regional product and the unemployment rate, were studied based on the economic and statistical models and the statistical data for Russian regions for 1997-2017.

Results. The study has revealed the increasing discrepancy between the aggregates of the labor market - the registered unemployment rate and the unemployment rate according to the conducted sample surveys of the population. The inertia of the indicator of "the registered unemployment rate", associated with the institutional constraints of the labor market, has been shown. The slow response of the gross regional product to the change in the aggregates of unemployment has been revealed. No clear correlation has been observed between volumes of output and changes in the unemployment rate according to the methodology of the International Labour Organization based on the data from the sample labor force surveys.

Discussion and Conclusion. The increasing divergence of aggregates of unemployment reveals a distortion of the formal institutional environment of the labor market and is due to the financial constraints of public authorities. Further research will focus on the assessment 
of the impact of the sectoral structure of the economy on the closeness of the correlation between changes in the gross regional product and the aggregates of the labor market. Understanding the trends in the development of the labor market is necessary for conducting a balanced policy of managing its transformation and the socio-economic development of the regions and the country as a whole.

Keywords: unemployment rate, gross regional product, Okun's law, regression model, economic growth

The author declares that there is no conflict of interest.

Funding. The article was done as part of the implementation of the government assignment to the Institute of Economic of the Karelian Research Centre of the Russian Academy of Sciences, the research topic "Revealing the synergetic patterns of regional socio-ecologicaleconomic systems and modeling of dynamic processes of sustainable development in multicomponent systems of different nature".

Acknowledgements. The author expresses gratitude to the reviewers whose comments helped to improve the quality of the article.

For citation: Kurilo A.E. Long-Term Trends in Regional Labor Markets in Russia. Regionology $=$ Russian Journal of Regional Studies. 2021; 29(2):427-446. DOI: https://doi. org/10.15507/2413-1407.115.029.202102.427-446

Введение. Безработица в рыночной экономике является одной из важных макроэкономических проблем, поскольку оказывает существенное влияние на социально-экономическое развитие. Одним из макроэкономических индикаторов экономической системы считается рынок труда, состояние которого во многом отражает функционирование экономики страны. По мнению некоторых ученых, безработица выступает самым значительным риском, с которым сталкиваются люди, и с течением времени она может привести к росту бедности и неравенства [1]. В связи с этим безработица продолжает оставаться одним из фундаментальных вопросов макроэкономики, исследованием которого занимаются ученые.

Растет понимание того, что рынки труда недостаточно эффективно распределяют плоды экономического роста, и возникающее в результате этого неравенство создает угрозу социальной сплоченности ${ }^{1}$. Потеря работы оказывает негативное воздействие на субъективное восприятие социальной интеграции, удовлетворенность жизнью, доступ к экономическим ресурсам и психическое здоровье [2]. Оценка тенденций трансформации рынка труда необходима для разработки взвешенной социальной и экономической политики, способной формировать инклюзивный и устойчивый путь развития.

Цель статьи - на основе проведенного исследования выявить долгосрочные тенденции развития региональных рынков труда и взаимосвязи безработицы и объемов производства.

${ }^{1}$ World Employment and Social Outlook: Trends 2020 International Labour Office. Geneva: ILO, 2020. 127 p. 
Обзор литературы. Эмпирическая зависимость экономических показателей, характеризующих объем производства и тенденции рынка труда, была сформулирована А. Оукеном более полувека назад. На статистических данных Соединенных Штатов Америки за 1954-1962 гг. было показано, что изменение валового внутреннего продукта на 1 процентный пункт изменяет безработицу на $n$ процентных пунктов (для США $\mathrm{n}=3)^{2}$. Данная зависимость носит название «закон Оукена» и описывает эмпирическую связь между изменениями безработицы и объема производства на макроэкономическом уровне. Однако вопрос о тесноте взаимосвязи остается дискуссионным. А. Л. Грант в своей статье показывает, что для американской экономики существует значительная временная вариация коэффициента Оукена; это свидетельствует о значительной степени неопределенности в оценке объема производства и естественного уровня безработицы [3].

Исследователи проверяли выполнение этого закона на статистических данных разных стран. Например, в странах Большой семерки закон действует неравномерно: зависимость между ВВП и безработицей сильна только в США и Франции, менее проявляется в Канаде, Великобритании и Германии и является слабой в Италии и Японии. Н. Бенос и А. Ставракудис считают, что данные выводы повышают обоснованность закона Оукена, «не делая его недействительным в Италии и Японии, поскольку все еще существует отрицательная зависимость» [4]. Использование модифицированной версии Закона Оукена дает высокую точность зависимости для таких стран, как Австралия, Канада, Франция, Япония, Великобритания и США [5].

Для экономики Румынии была дана положительная оценка проверки действенности закона Оукена и выявлена связь между безработицей и экономическим ростом в период 1999-2008 гг. [6; 7]. В Бразилии соотношение между ВВП и уровнем занятости является значительным [8], а для пакистанской экономики «закон Оукена не существует» [9], наличие эмпирической зависимости не установлено. Авторы связывают невыполнение закона с разрывом между предложением рабочей силы и спросом на нее, что объясняется отсутствием достаточного уровня образования и квалификации безработных.

Данная эмпирическая зависимость проверялась на макроэкономическом уровне, а финские исследователи провели анализ взаимосвязи в открытых экономических системах мезоуровня. Они подтвердили наличие коинтеграции данных по финским регионам. Долгосрочная зависимость закона Оукена для регионов Финляндии подтверждает результаты, полученные для других стран на макроэкономическом уровне [10]. Для автономий Испании выявлены существенные региональные различия оценочных коэффициентов Оукена, что требует, как указывают авторы, проведения различной антициклической

${ }^{2}$ Okun A. M. Potential GNP: Its Measurement and Significance. Proceedings of the Business and Economic Statistics Section of the American Statistical Association. Alexandria, VA: American Statistical Association, 1962. 
политики, адаптированной с учетом территориальной специфики автономных сообществ (регионов страны) [11]. Американские ученые также провели оценку коэффициентов Оукена для штатов США, выявив показатели гибкости территориальных рынков труда: более высокий уровень образования населения, более низкий уровень объединения в профсоюзы и более высокую долю непроизводственной занятости [12].

На российских статистических данных проводилось мало аналогичных исследований. Для России за период 1994-2004 гг. выявлено слабое взаимное влияние ВВП и безработицы. Так, О. В. Ахундова, А. Г. Коровкин, И. Б. Королев пишут, что показатели «оказались довольно инертными», была выявлена неустойчивость проявления данной зависимости [13]. В интервале 1995-2013 гг. получено подтверждение взаимосвязи ВВП и безработицы, при этом коэффициент Оукена сопоставим со значениями данного показателя для стран с формирующимися рынками [14]. О. В. Баканач, Н. В. Проскурина полагают, что на уровне федеральных округов существует «умеренная отрицательная зависимость между уровнем фактической безработицы и индексом физического объема ВРП» [15].

На изменение уровня безработицы влияют и другие факторы, например низкая производительность труда [16]. Данную тенденцию можно преодолеть за счет повышения инвестиционной активности в регионах и обновления основных средств. В связи с этим актуализируется задача проведения взвешенной государственной региональной инвестиционной политики в части обновления производственных фондов и применения современных технологий [17], в том числе цифровых. Так, внедрение цифровых технологий позволит увеличить производительность труда в экономике [18] и в секторе госуправления [19], что в свою очередь позитивно отразится на росте производства в регионах. Наряду с этим процесс бурной цифровизации ведет к повышению мобильности работников и возникновению регулярной прерывистости процесса накопления специфического человеческого капитала, но пока такая тенденция проявляется медленно, и продолжает доминировать традиционная модель внутрифирменной стабильности [20].

При проведении государственной политики, направленной на снижение безработицы, необходимо принимать во внимание достаточно широкий спектр факторов (как экономических, так и социальных). Например, институциональные изменения увеличения пенсионного возраста потенциально искажают механизм понижения безработицы за счет снижения ротации рабочих мест претендентами более молодых возрастов. К тому же недостаточное количество мест для детей в дошкольных учреждениях образования влияет на увеличение уровня безработицы [21].

В современных условиях появляются различные формы прекаризации труда, которые сложно поддаются количественной оценке. Возникновение новых форм занятости имеет двойственный характер: способствуя повышению 
экономической активности, они снижают устойчивость положения работника, что негативно отражается на качестве трудовой жизни. На общественном уровне они проявляются через нарушение функционирования рынка труда, увеличивая неопределенность в отношении его конъюнктуры и росте безработицы, углублении социального неравенства и замедлении социально-экономического развития [22].

К тому же следует учитывать, что жесткая государственная политика поддержания занятости способствует повышению маргинализации общества в связи с падением уровня и качества жизни населения [23]. В данном контексте актуализируется необходимость совершенствования региональной политики в направлении создания высокопроизводительных и высокооплачиваемых рабочих мест. Повышение занятости за счет увеличения числа низкооплачиваемых рабочих мест ведет к деградации человеческого капитала и расширению границ бедности [24]. Как считает А. Бжезинский, государственные расходы на проведение активной политики на рынке труда генерируют позитивный синергетический эффект, выражающийся в повышении качества рабочей силы [25].

Кроме того, решение проблемы безработицы можно рассматривать в пространственном аспекте - «в смещении центров развития на периферию» [26] через формирование и совершенствование удаленных форм занятости, что должно положительно отразиться на повышении экономической активности населения и снижении дифференциации российских регионов.

Проведенный обзор научных источников показывает многоаспектность рынка труда и слабую изученность взаимосвязи безработицы и экономического роста на региональном уровне.

Материалы и методы. В ходе исследования проведен анализ взаимосвязи динамики ВРП и уровня безработицы в российских регионах. В работе использованы открытые статистические данные, предоставляемые Федеральной службой государственной статистики в статистических сборниках «Регионы России» ${ }^{3}$.

Для выявления тенденций развития региональных рынков труда применялись методы компаративного, экономического и статистического анализа данных. Прослежена динамика изменения уровней зарегистрированной безработицы и безработицы по данным выборочных обследований рабочей силы за период 1993-2019 гг. Были проанализированы тенденции, которые формируются в регионах Российской Федерации на региональных рынках труда.

Построены регрессионные модели за временной период 1997-2017 гг., включающие в себя данные по 79 субъектам Федерации. Из расчетов исключены Республика Крым, г. Севастополь и Чеченская Республика в силу

${ }^{3}$ Регионы России. Социально-экономические показатели [Электронный ресурс]. Стат. сб. / Росстат. М. 2002-2019. URL: https://rosstat.gov.ru/folder/210/document/13204 (дата обращения: 21.10.2020). 
отсутствия статистических показателей за весь рассматриваемый период. Расчеты проведены для совокупности субъектов Федерации за каждый год из данного интервала и по каждому субъекту за весь временной интервал и за период 2002-2017 гг.:

$$
\begin{aligned}
& \text { Index Physical Volume } G D P_{j}=A+B \times I L O \text { Unemployment Rate Dynamics }_{j}, \\
& \text { Index Physical Volume } G R P_{i j}=A+B \times I L O \text { Unemployment Rate Dynamics }_{i j} \text {, }
\end{aligned}
$$

где Index Physical Volume $G D P_{j}-$ индекс физического объема ВВП в Российской Федерации за $j$-тый период, $\% ; A$ - свободный член; $B$ - коэффициент; ILO Unemployment Rate Dynamics ${ }_{j}$ - изменение уровня безработицы (MOT) в Российской Федерации за ј-тый период, \%; Index Physical Volume GRP ${ }_{i j}-$ индекс физического объема ВРП в $i$-том субъекте Федерации за $j$-тый период, ILO Unemployment Rate Dynamics ${ }_{i j}$ - изменение уровня безработицы (МОT) в $i$-том субъекте Федерации за $j$-тый период, \%.

Использованы методы графического представления социально-экономической информации.

Результаты исследования. В России рынок труда начал формироваться в результате трансформации экономических отношений в начале 1990-х гг. Институционально государственная политика на рынке труда закреплена в Федеральном законе «О занятости населения в Российской Федерации», поскольку поддержание занятости является важной народнохозяйственной задачей ${ }^{4}$. Кроме того, уровень безработицы выступает как индикатор экономической безопасности при реализации региональной политики [27]. Изучение показателей, отражающих состояние безработицы на региональном уровне, позволяет выявить тенденции трансформации рынка труда.

Статистические показатели уровня безработицы отражаются в статистических сборниках с 1993 г. и дают возможность построения динамических рядов. В справочниках представлены показатели уровня зарегистрированной безработицы и безработицы по данным выборочных обследований рабочей силы.

Уровень зарегистрированной безработицы мало подвижен. В целом по России он сократился до 81,8 \% по отношению к 1993 г. Можно выделить регионы со снижением и увеличением данного показателя по сравнению с 1993 г. Инертность уровня безработицы можно объяснить спецификой ключевых институтов рынка труда: наличием минимальной заработной платы, формальных институтов, защищающих занятость, и т. д. Уровень безработицы по данным выборочных обследований хотя и «искажает реальную ситуацию» [28], но ведет себя более подвижно, что позволяет выявить тенденции развития рынка труда. На рисунке 1 представлена динамика изменения

${ }^{4}$ О занятости населения в Российской Федерации: Закон Российской Федерации от 19.04.1991 № 1032-1. 
уровня безработицы по данным выборочных обследований рабочей силы по регионам Российской Федерации по отношению к 1993 г. На графике приведены данные по России и примеры регионов, у которых уровень безработицы вырос к уровню 1993 г. до 150 \% и более и сократился до 50 \% и менее. У основной массы регионов этот показатель к уровню 1993 г. колеблется в диапазоне 50-150 \%. До 1998-1999 гг. этот показатель по большинству регионов увеличивался, а затем мы наблюдаем его снижение.

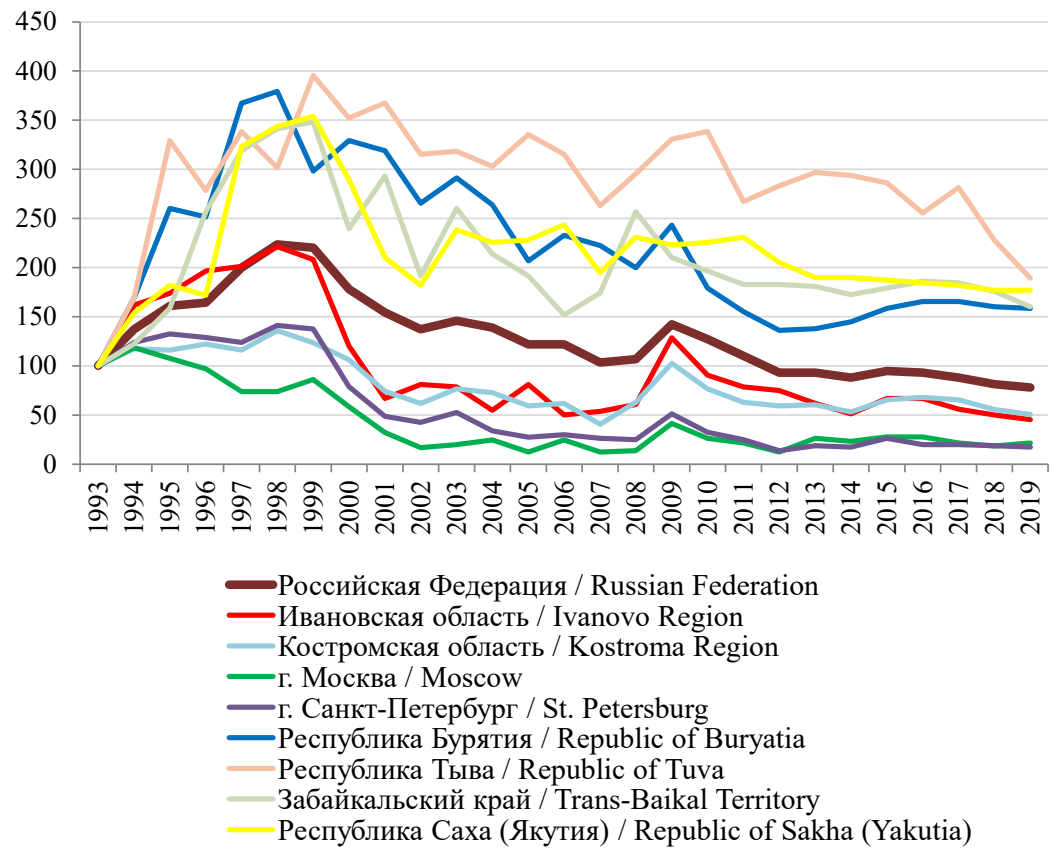

Р и с. 1. Уровень безработицы по данным выборочных обследований рабочей силы по регионам России за 1993-2019 гг., \% к 1993 г.

F i g. 1. Unemployment rate according to sample surveys of the labor force in the regions of Russia for $1993-2019, \%$ to 1993

В 2012 г. происходит увеличение уровня безработицы, и далее к 2018 г. опять фиксируется снижение показателя. К 2018 г. формируются две группы субъектов Российской Федерации: регионы с уровнем безработицы меньше, чем в 1993 г., и регионы, не достигающие данных показателей. Крайние нижние тренды демонстрируют снижение показателя в городах федерального значения - Москве и Санкт-Петербурге. Самые высокие темпы роста наблюдаются в Республике Тыва. С 1998 г. происходят колебания уровня безрабо- 
тицы, но в целом прослеживается тенденция к снижению этого показателя по данным выборочных обследований.

При расчете отношения уровня безработицы по данным обследований к уровню зарегистрированной безработицы за период 1993-2018 гг. выявлено несколько этапов сходимости данных показателей. С 1993 по 1996 г. происходит снижение различий в размере показателей, далее до 1999-2000 гг. увеличение расхождения, с 2000 г. с небольшими колебаниями - снижение со всплеском в 2009 г. С 2009 г. наблюдается усиление дифференциации регионов по данному критерию. Усиление расхождения уровней безработицы может свидетельствовать об искажении формальных институтов рынка труда. Динамика регистрируемой безработицы в большей степени связана с финансовыми ограничениями органов власти: при их ужесточении уровень зарегистрированной безработицы снижается, при ослаблении - увеличивается.

Для анализа взаимосвязи изменения ВРП и уровня безработицы использованы относительный показатель - индекс физического объема, отражающий изменение объема ВРП, и уровень безработицы согласно методологии Международной организации труда (MOT) - уровень безработицы по данным выборочных обследований рабочей силы за период 1997-2017 гг., поскольку они доступны в статистических сборниках.

На рисунке 2 представлена динамика ВВП и уровня безработицы по данным выборочных обследований. В периоды кризисов 1998 и 2009 гг. видны заметные всплески данных индекса физического объема ВВП и уровня безработицы в Российской Федерации, а изменение уровня безработицы по отношению к предыдущему году (реакция рынка труда) имеет очень неустойчивую тенденцию и в остальные годы. Взаимосвязь этих показателей по регрессионной модели (1) представлена на рисунке 3. На макроэкономическом уровне прослеживается заметная связь влияния изменения уровня безработицы на ВВП за период 1997-2017 гг. $\left(\mathrm{R}^{2}=0,51\right)$.

Для выявления зависимости на региональном уровне построены регрессионные модели (cross section) (2) за каждый год из данного диапазона по данным совокупности регионов Российской Федерации. Выявлено усиление взаимосвязи в 2002 г. $\left(\mathrm{R}^{2}=0,11\right), 2005$ г. $\left(\mathrm{R}^{2}=0,15\right)$ и 2009 г. $\left(\mathrm{R}^{2}=0,18\right)$, в остальные годы $\mathrm{R}^{2}<0,1$, что говорит о неустойчивости данной связи, но к концу интервала она проявляется с большей силой.

Построены регрессионные модели (2) для каждого региона за периоды 1997-2017 гг. и 2002-2017 гг. (исключены Республика Крым, г. Севастополь, Чеченская Республика). Информация о коэффициенте детерминации зависимостей представлена в таблице. Из 79 субъектов в первом интервале умеренная и заметная зависимость наблюдалась у 18 субъектов, а во втором - уже у 22. У большинства субъектов проявляется усиление взаимосвязи по данной регрессионной модели. 


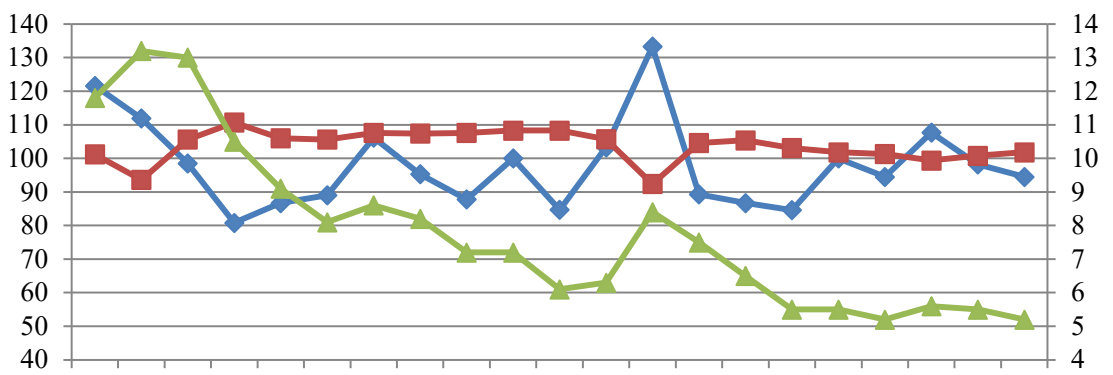

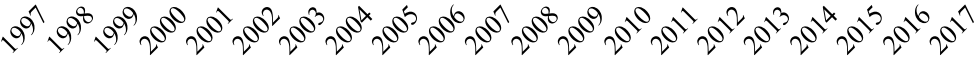

—Уровень безработицы (МОТ), \% к предыдущему году / Unemployment rate (ILO), \% to the previous year

- Индекс физического объема ВВП, \% к предыдущему году / Index of the physical volume of the GDP, $\%$ to the previous year

- Уровень безработицы (МОТ), \% (правая ось) / Unemployment rate (ILO), \% (right axis)

Р и с. 2. Индекс физического объема ВВП и уровень безработицы по данным выборочных обследований рабочей силы в России за 1997-2017 гг.

$\mathrm{F}$ i g. 2. Index of the physical volume of the GDP and the unemployment rate according to sample surveys of the labor force in Russia for 1997-2017
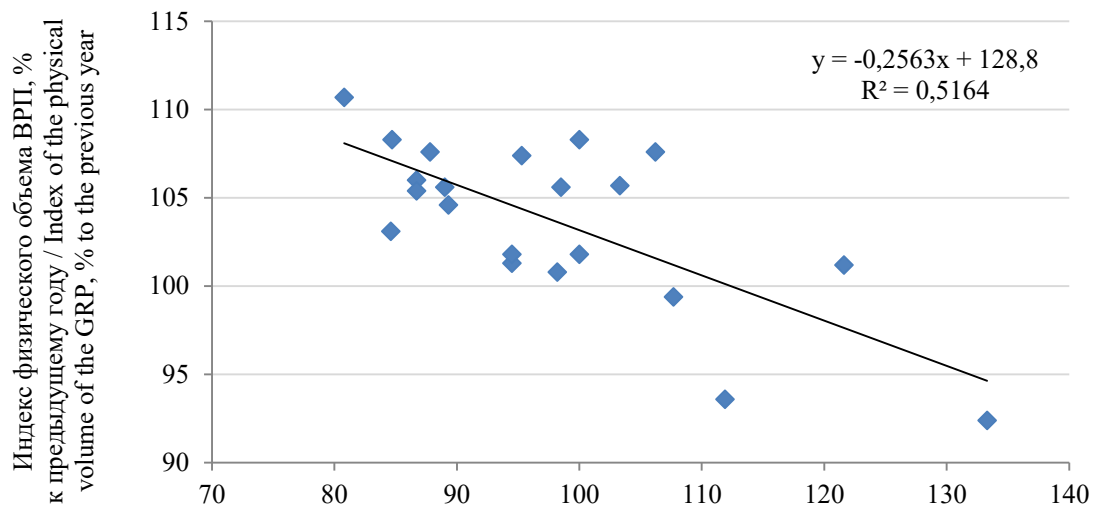

Прирост уровня безработицы (МОТ), \% к предыдущему году / Unemployment rate growth (ILO), $\%$ to the previous year

Р и с. 3. Зависимость индекса физического объема ВВП от изменения уровня безработицы (МОТ) в России по модели (1) за 1997-2017 гг.

F i g. 3. Dependence of the index of the physical volume of the GDP on the change in the unemployment rate (ILO) in Russia according to the model (1) for 1997-2017 
Т а б л и ц а. Коэффициенты детерминации зависимости (2) за периоды 1997-2017, 2002-2017 гг.*

$\mathrm{T}$ a $\mathrm{b} 1 \mathrm{e}$. Coefficients of determination of the dependence (2) for the periods of 1997-2017, 2002-2017

\begin{tabular}{|c|c|c|c|c|c|}
\hline Регион / Region & $\begin{array}{l}1997- \\
2017 \\
\end{array}$ & $\begin{array}{l}2002- \\
2017\end{array}$ & Регион / Region & \begin{tabular}{|l|}
$1997-$ \\
2017 \\
\end{tabular} & $\begin{array}{r}2002- \\
2017\end{array}$ \\
\hline \multicolumn{3}{|c|}{$\begin{array}{l}\text { Центральный федеральный округ / } \\
\text { Central Federal District }\end{array}$} & \multicolumn{3}{|c|}{$\begin{array}{c}\text { Приволжсский федеральный округ / } \\
\text { Volga Federal District }\end{array}$} \\
\hline $\begin{array}{l}\text { Брянская область / } \\
\text { Bryansk Region }\end{array}$ & 0,52 & 0,57 & $\begin{array}{l}\text { Республика Марий Эл / } \\
\text { Republic of Mari El }\end{array}$ & 0,12 & 0,41 \\
\hline $\begin{array}{l}\text { Владимирская область / } \\
\text { Vladimir Region }\end{array}$ & 0,25 & 0,40 & $\begin{array}{l}\text { Республика Мордовия / } \\
\text { Republic of Mordovia }\end{array}$ & 0,44 & 0,50 \\
\hline $\begin{array}{l}\text { Воронежская область / } \\
\text { Voronezh Region }\end{array}$ & 0,31 & 0,32 & $\begin{array}{l}\text { Республика Татарстан / } \\
\text { Republic of Tatarstan }\end{array}$ & 0,39 & 0,23 \\
\hline $\begin{array}{l}\text { Калужская область / } \\
\text { Kaluga Region }\end{array}$ & 0,39 & 0,44 & $\begin{array}{l}\text { Чувашская Республика / } \\
\text { Chuvash Republic }\end{array}$ & 0,35 & 0,40 \\
\hline $\begin{array}{l}\text { Костромская область / } \\
\text { Kostroma Region }\end{array}$ & 0,32 & 0,34 & $\begin{array}{l}\text { Кировская область / } \\
\text { Kirov Region }\end{array}$ & 0,31 & 0,20 \\
\hline $\begin{array}{l}\text { Kурская область / } \\
\text { Kursk Region }\end{array}$ & 0,29 & 0,33 & $\begin{array}{l}\text { Нижегородская область / } \\
\text { Nizhny Novgorod Region }\end{array}$ & 0,16 & 0,34 \\
\hline $\begin{array}{l}\text { Московская область / } \\
\text { Moscow Region }\end{array}$ & 0,32 & 0,36 & $\begin{array}{l}\text { Oренбургская область / } \\
\text { Orenburg Region }\end{array}$ & 0,05 & 0,35 \\
\hline $\begin{array}{l}\text { Орловская область / } \\
\text { Orel Region }\end{array}$ & 0,25 & 0,55 & $\begin{array}{l}\text { Самарская область / } \\
\text { Samara Region }\end{array}$ & 0,30 & 0,50 \\
\hline $\begin{array}{l}\text { Смоленская область / } \\
\text { Smolensk Region }\end{array}$ & 0,31 & 0,17 & \multicolumn{3}{|c|}{$\begin{array}{l}\text { Уральский федеральный округ / } \\
\text { Ural Federal District }\end{array}$} \\
\hline $\begin{array}{l}\text { Тульская область / } \\
\text { Tula Region }\end{array}$ & 0,39 & 0,43 & $\begin{array}{l}\text { Свердловская область / } \\
\text { Sverdlovsk Region }\end{array}$ & 0,50 & 0,54 \\
\hline $\begin{array}{l}\text { г. Москва / } \\
\text { Moscow }\end{array}$ & 0,23 & 0,30 & $\begin{array}{l}\text { Челябинская область / } \\
\text { Chelyabinsk Region }\end{array}$ & 0,46 & 0,48 \\
\hline \multicolumn{3}{|c|}{$\begin{array}{c}\text { Северо-Западный федеральный округ / } \\
\text { Northwestern Federal District }\end{array}$} & \multicolumn{3}{|c|}{$\begin{array}{l}\text { Cибирский федеральный округ / } \\
\text { Siberian Federal District }\end{array}$} \\
\hline $\begin{array}{l}\text { Псковская область / } \\
\text { Pskov Region }\end{array}$ & 0,20 & 0,36 & $\begin{array}{l}\text { Kрасноярский край / } \\
\text { Krasnoyarsk Territory }\end{array}$ & 0,34 & 0,27 \\
\hline \multicolumn{3}{|c|}{$\begin{array}{l}\text { Южный федеральный округ / } \\
\text { Southern Federal District }\end{array}$} & $\begin{array}{l}\text { Иркутская область / } \\
\text { Irkutsk Region }\end{array}$ & 0,33 & 0,42 \\
\hline $\begin{array}{l}\text { Краснодарский край / } \\
\text { Krasnodar Territory }\end{array}$ & 0,33 & 0,43 & $\begin{array}{l}\text { Новосибирская область / } \\
\text { Novosibirsk Region }\end{array}$ & 0,51 & 0,45 \\
\hline $\begin{array}{l}\text { Астраханская область / } \\
\text { Astrakhan Region }\end{array}$ & 0,31 & 0,23 & & & \\
\hline $\begin{array}{l}\text { Ростовская область / } \\
\text { Rostov Region }\end{array}$ & 0,43 & 0,50 & & & \\
\hline
\end{tabular}

* Субъекты Федерации, по которым коэффициент детерминации за оба периода показывает слабую зависимость $\left(\mathrm{R}^{2}<0,3\right)$, исключены из таблицы / Constituent entities of the Russian Federation, for which the coefficient of determination for both periods shows a weak dependence $\left(\mathrm{R}^{2}<0.3\right)$, are excluded from the table. 
Поскольку выявлено усиление зависимости в интервале 2002-2017 гг., была построена регрессионная модель (2) за 2017 г., учитывающая долгосрочный период, в которой использованы показатели изменения индекса физического объема ВРП и уровня безработицы (МОТ) в 2017 г. по отношению к 2002 г. В целом по регионам Российской Федерации такая зависимость не обнаружена. По регионам Центрального федерального округа выявлено наличие слабой зависимости $\left(\mathrm{R}^{2}=0,15\right)$, при этом степенная функция показывает более тесную связь $\left(\mathrm{R}^{2}=0,23\right)$ (рис. 4$)$.
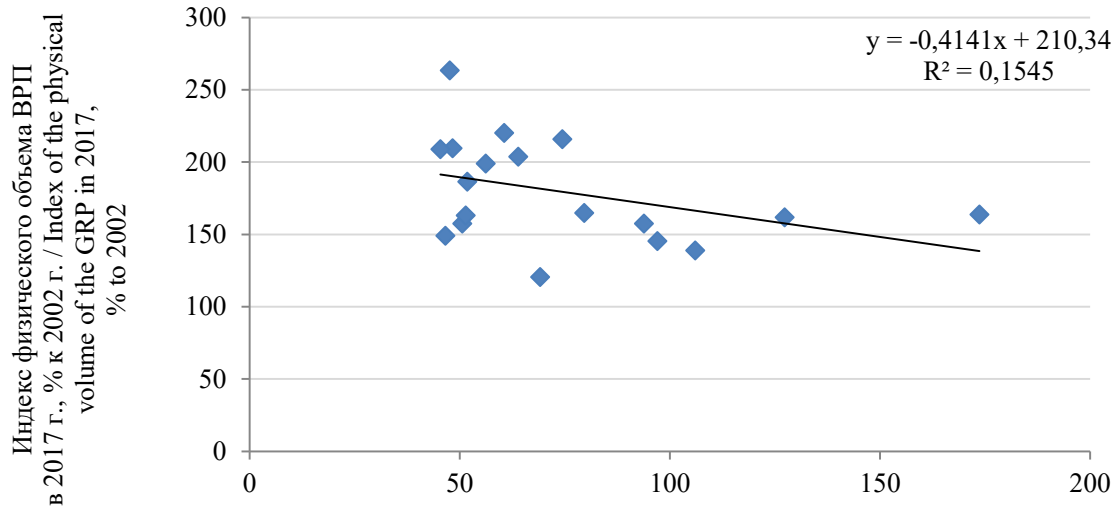

Изменение уровня безработицы (МОТ) в 2017 г., \% к 2002 г. / Change in the unemployment rate (ILO) in $2017, \%$ to 2002

Р и с. 4. Зависимость изменения индекса физического объема ВРП от изменения уровня безработицы (МОТ) в регионах Центрального федерального округа в 2017 г. по отношению к 2002 г.

F i g. 4. Dependence of the change in the index of the physical volume of the GRP on the change in the unemployment rate (ILO) in the regions of the Central Federal District in 2017 in relation to 2002

Таким образом, для российских регионов на основании модели (2) в долгосрочном интервале 2002-2017 гг. не выявлено значимой взаимосвязи экономического роста и изменения уровня безработицы (МОТ). При группировке регионов по признаку принадлежности к федеральным округам, слабая зависимость выявлена для субъектов Центрального федерального округа, что говорит о более высокой степени развития экономических систем регионов этого округа.

Обсуждение и заключение. В результате анализа показателей, отражающих трансформацию рынка труда, выявлены неоднозначные тенденции влияния безработицы на объемы выпуска продукции. Наблюдается слабая реакция ВРП на изменение агрегированных показателей безработицы. 
Данные интерпретации исследуемой зависимости позволяют судить о неравномерном развитии регионов и округов Российской Федерации. В слаборазвитых регионах зависимость не выполняется, а для регионов Центрального федерального округа взаимосвязь теснее, что свидетельствует о большем уровне развития рыночной экономики регионов, входящих в состав округа. Однако можно говорить об усилении рыночных тенденций в экономической системе Российской Федерации [29]. Слабое выполнение зависимости указывает на то, что увеличение или уменьшение в численности безработных не вызывает соответствующего изменения ВРП в противоположном направлении.

Для снижения диспропорций рынка труда и повышения качества рабочей силы следует стремиться к расширению таргетированных учебных программ для безработных, реализация которых повышает квалификацию и мотивированность людей, ищущих работу. Для снижения диспропорций молодежного рынка труда в учебных заведениях профессионального образования следует использовать практико-ориентированный подход, предполагающий внедрение модели дуального образования. В связи с этим необходимо расширение диалога органов региональной и муниципальной власти с работодателями. Данному процессу может способствовать закрепление интересной практики Амурской области по получению релевантной социологической информации с использованием QR-кода для выявления причин, по которым выпускники учебных заведений не планируют трудоустраиваться по специальности.

На региональном уровне необходимо активнее проводить работу по подготовке инвестиционных паспортов и инвестиционных площадок, а также по выявлению предпринимательских инициатив населения и удовлетворению запроса по созданию собственного дела. Такую работу по сбору и обработке информации, например, можно проводить через сайты региональных служб занятости. В регионах формируется потребность в расширении государственных субсидий на создание новых рабочих мест и возобновление программ поддержки самозанятых через выдачу грантов, а не только микрозаймов и льгот.

Таким образом, при проведении региональной политики по снижению безработицы необходимо решать сложную многофакторную задачу, учитывая как количественные, так и качественные трансформации рынка труда.

Исследование расширило понимание тенденций развития рынка труда в регионах России. Выявлено усиление расхождения агрегированных показателей безработицы - уровня зарегистрированной безработицы и уровня безработицы, определяемого по результатам выборочных обследований рабочей силы. Сложившаяся тенденция отражает искажение формальной институциональной среды рынка труда и обусловлена финансовыми ограничениями, накладываемыми органами власти. Прослеживается заметная связь макроэкономических показателей: индекса физического объема ВВП и темпов изменения уровня безработицы (МОТ) в Российской Федерации. 
Показано, что в современной России в период 1997-2017 гг. на региональном уровне наблюдается слабая реакция ВРП на изменение количественных показателей безработицы, при этом в целом для страны подтверждается заметная взаимосвязь данных критериев. Не выявлено устойчивой зависимости между уровнем фактической безработицы и физическим объемом ВРП, но происходит усиление зависимости между данными показателями с течением времени. Наблюдается слабая реакция ВРП на изменение агрегированных показателей безработицы. Долгосрочная зависимость закона Оукена на мезоэкономическом уровне для регионов Российской Федерации является неустойчивой. По характеру влияния можно говорить об усилении реакции ВРП, что отражает усиление рыночных тенденций на уровне открытых региональных экономических систем. Понимание взаимосвязи между данными показателями необходимо для проведения взвешенной политики управления трансформацией рынка труда и социально-экономическим развитием регионов и страны в целом.

Государственная региональная политика должна быть направлена на снижение уровня реальной безработицы и повышение объемов производства через содействие созданию высокопроизводительных рабочих мест, что позволит в итоге достичь увеличения темпов социально-экономического развития в регионах. Для успешного социально-экономического развития регионов и преодоления деструктивных тенденций, сформировавшихся на российском рынке труда, необходимо выстраивать системную работу по их преодолению.

Практическая значимость исследования заключается в возможности использования его результатов органами государственной власти при разработке мероприятий государственной политики снижения безработицы. Материалы могут быть полезны для исследователей, изучающих закономерности развития рынка труда. Дальнейшие исследования будут направлены на выявление зависимости экономического роста, безработицы и структуры экономики на региональном уровне.

\section{СПИСОК ИСПОЛЬЗОВАННЫХ ИСТОЧНИКОВ}

1. Stability with Growth. Macroeconomics, Liberalization, and Development / J. E Stiglitz, J. A. Ocampo, Sh. Spiegel [et al.]. - Oxford : Oxford University Press, 2006. - 339 p. - URL: http://www.library.fa.ru/files/Stiglitz-Stability.pdf (дата обращения: 21.10.2020).

2. Pohlan, L. Unemployment and Social Exclusion / L. Pohlan. - DOI 10.1016/j. jebo.2019.06.006 // Journal of Economic Behavior and Organization. - 2019. Vol. 164. - Pp. 273-299. - URL: https://www.sciencedirect.com/science/article/pii/ S0167268119301969?via\%3Dihub (дата обращения: 21.10.2020).

3. Grant, A. L. The Great Recession and Okun's Law / A. L. Grant. - DOI 10.1016/j. econmod.2017.10.002 // Economic Modelling. - 2018. - Vol. 69. - Pp. 291-300. - URL: 
https:/www.sciencedirect.com/science/article/pii/S0264999317308799?via\%3Dihub (дата обращения: 21.10.2020).

4. Benos, N. Okun's Law: Copula-Based Evidence from G7 Countries / N. Benos, A. Stavrakoudis. - DOI 10.1016/j.qref.2020.10.004 // The Quarterly Review of Economics and Finance. - 2020. - URL: https:/www.sciencedirect.com/science/article/pii/ S1062976920301216?via\%3Dihub (дата обращения: 21.12.2020).

5. Kitov, I. Modeling Unemployment and Employment in Advanced Economies: Okun's Law with a Structural Fracture / I. Kitov, O. Kitov // Theoretical and Practical Research in Economic Fields. - 2012. - Vol. 3, no. 1. - Pp. 26-41. - URL: https://journals.aserspublishing.eu/tpref/article/view/1167 (дата обращения: 21.10.2020).

6. Dinu, M. Testing of the Okun's Law in Romania / M. Dinu, M. C. Marinaş // Economic Computation and Economic Cybernetics Studies. - 2011. - No. 1. - Pp. 5-20. - URL: http:// www.ecocyb.ase.ro/12011\%20pdf/marin\%20dinu.pdf (дата обращения: 21.10.2020).

7. Simionescu, M. Improving Unemployment Rate Forecasts at Regional Level in Romania Using Google Trends / M. Simionescu. - DOI 10.1016/j.techfore.2020.120026 // Technological Forecasting and Social Change. - 2020. - Vol. 155. - URL: https://www.sciencedirect.com/science/article/pii/S004016251930455X?via\%3Dihub (дата обращения: 21.12.2020).

8. Jin, Zh. Okun's Law: an Empirical Test Using Brazilian Data / Zh. Jin, A. Harper // Research in Business and Economics Journal. - 2019. - Vol. 13. - URL: https://scholar. valpo.edu/cba fac pub/72/ (дата обращения: 21.10.2020).

9. An Empirical Estimation of Okun's Law in Context of Pakistan / M. Akram, Sh. Hussain, S. H. Raza, S. Masood. - DOI 10.12691/jfe-2-5-7 // Journal of Finance and Economics. - 2014. - Vol. 2, no. 5. - Pp. 173-177. - URL: http://pubs.sciepub.com/jfe/2/5/7/ index.html (дата обращения: 21.10.2020).

10. Kangasharju, A. Regional Growth and Unemployment: The Validity of Okun's Law for the Finnish Regions / A. Kangasharju, Ch. Tavera, P. Nijkamp. - DOI 10.1080/17421772.2012.694141 // Spatial Economic Analysis. - 2012. - Vol. 7, issue 3. Pp. 381-395. - URL: https:/www.tandfonline.com/doi/full/10.1080/17421772.2012.694141 (дата обращения: 21.10.2020).

11. Porras-Arena, M. S. Self-Employment and the Okun's Law / M. S. Porras-Arena, A. L. Martín-Románc. - DOI 10.1016/j.econmod.2018.09.006 // Economic Modelling. 2019. - Vol. 77. - Pp. 253-265. - URL: https://www.sciencedirect.com/science/article/pii/ S0264999318302360?via\%3Dihub (дата обращения: 21.10.2020).

12. A State-Level Analysis of Okun's Law / A. Y. Guisinger, R. Hernandez-Murillo, M. T. Owyang, T. M. Sinclair. - DOI 10.1016/j.regsciurbeco.2017.11.005 // Regional Science and Urban Economics. - 2018. - Vol. 68. - Pp. 239-248. - URL: https://www.sciencedirect. com/science/article/pii/S0166046217300327?via\%3Dihub (дата обращения: 21.10.2020).

13. Ахундова, О. В. Взаимосвязь динамики ВВП и безработицы: теоретический и практический анализ / О. В. Ахундова, А. Г. Коровкин, И. Б. Королев // Научные труды: Институт народнохозяйственного прогнозирования РАН. - 2005. - Т. 3. C. 471-495. - URL: https://ecfor.ru/publication/vzaimosvyaz-dinamiki-vvp-i-bezrabotitsy/ (дата обращения: 21.10.2020).

14. Вакуленко, Е. С. Взаимосвязь ВВП, безработицы и занятости: углубленный анализ закона Оукена для России / Е. С. Вакуленко, Е. Т. Гурвич. - DOI 10.32609/0042- 
8736-2015-3-5-27 // Вопросы экономики. - 2015. - № 3. - C. 5-27. - URL: https://www. vopreco.ru/jour/article/view/57 (дата обращения: 21.10.2020). - Рез. англ.

15. Баканач, О. В. Статистический анализ безработицы в Российской Федерации в разрезе федеральных округов / О. В. Баканач, Н. В. Проскурина // Системное управление. - 2016. - № 2 (31). - C. 4-11. - URL: http://sisupr.mrsu.ru/2016-2/PDF/Bakanach. pdf (дата обращения: 21.10.2020). - Рез. англ.

16. Рамазанов, Д. И. Взаимосвязь безработицы и валового регионального продукта в Ивановской области: опыт эмпирического анализа / Д. И. Рамазанов // Современные наукоемкие технологии. Региональное приложение. - 2019. - Т. 58, № 2. - C. 92-98. - URL: http:/journals.isuct.ru/snt/article/view/1504 (дата обращения: 21.10.2020). - Рез. англ.

17. Промахина, И. М. Эконометрический анализ взаимосвязи экономического роста и безработицы в Китае (1978-2006 гг.) / И. М. Промахина, Л. Ван // Вестник Российского университета дружбы народов. Серия: Экономика. - 2008. - № 3. C. 82-94. - URL: http://journals.rudn.ru/economics/article/view/12280 (дата обращения: 21.10.2020). - Рез. англ.

18. Дружинин, П. В. Оценка эффективности развития регионов Европейского севера на основе производственных функций / П. В. Дружинин, М. В. Морошкина. - DOI 10.17213/2312-6469-2019-5-217-231 // Друкеровский вестник. - 2019. - № 5 (31). - C. 218-231. - URL: http://drucker.npi-tu.ru/assets/files/dv-2019-5/21Druzhinin.pdf (дата обращения: 17.11.2020). - Рез. англ.

19. Курило, А. Е. Развитие электронного правительства в России: преимущества, барьеры и перспективы / А. Е. Курило, Е. А. Прокопьев. - DOI 10.33051/2500-23252019-4-015-027 // Проблемы рыночной экономики. - 2019. - № 4. - C. 15-27. - URL: http://www.market-economy.ru/archive/2019-04/2019-04-015-027-kurilo.pdf (дата обращения: 17.11.2020). - Рез. англ.

20. Токсанбаева, М. С. Масштабы, факторы и мотивы мобильности и стабильности на рынке труда / М. С. Токсанбаева. - DOI 10.24411/1999-9836-2019-10062 // Уровень жизни населения регионов России. - 2019. - № 2 (212). - C. 35-42. - URL: https:// doi.org/10.24411/1999-9836-2019-10062 (дата обращения: 17.11.2020). - Рез. англ.

21. Бакушева, Г. В. Эконометрический анализ воздействия факторов сферы образования на уровень безработицы в регионах России / Г. В. Бакушева // Хроноэкономика. - 2019. - № 3 (16). - C. 6-14. - URL: http://hronoeconomics.ru/journal_3.html (дата обращения: 17.11.2020). - Рез. англ.

22. Popov, A. V. Analyzing and Classifying the Implications of Employment Precarization: Individual, Organizational and Social Levels / A. V. Popov, T. S. Soloveva. - DOI 10.15838/esc.2019.6.66.10 // Economic and Social Changes: Facts, Trends, Forecast. 2019. - Vol. 12, no. 6. - Pp. 182-196. - URL: http://esc.vscc.ac.ru/article/28412?_lang=en (дата обращения: 21.10.2020).

23. Бартлин, Е. А. Об экономическом механизме реализации государственной политики занятости в России / Е. А. Бартлин. - DOI 10.24411/1999-9836-2018-10017 // Уровень жизни населения регионов России. - 2018. - № 2 (208). - C. 78-85. - URL: https:// doi.org/10.24411/1999-9836-2018-10017 (дата обращения: 17.11.2020). - Рез. англ.

24. Гимпельсон, В. Е. Низкооплачиваемые рабочие места на российском рынке труда: есть ли выход и куда он ведет? / В. Е. Гимпельсон, Р. И. Капелюшников, А. В. Шарунина. - DOI 10.17323/1813-8691-2018-22-4-489-530 // Экономический 
журнал ВШЭ. - 2018. - Т. 22, № 4. - C. 489-530. - URL: https://ej.hse.ru/2018-224/228581250.html (дата обращения: 17.11.2020). - Рез. англ.

25. Brzezinski, A. Synergies in Labour Market Institutions: the Nonlinear Effect of Minimum Wages on Youth Employment / A. Brzezinski. - DOI 10.1007/s11293-017-9537-7 // Atlantic Economic Journal. - 2017. - Vol. 45. - Pp. 251-263. - URL: https://ink.springer. com/article/10.1007/s11293-017-9537-7 (дата обращения: 21.10.2020).

26. Белов, В. И. Проблема безработицы в РФ и пути ее решения / В. И. Белов, А. Р. Биккулова // Меридиан. - 2020. - № 3 (37). - С. 9-11. - URL: http://meridian-journal.ru/site/article?id=2732 (дата обращения: 17.11.2020). - Рез. англ.

27. Безработица как индикатор экономической безопасности региона / В. В. Карпов, К. В. Петренко, Р. И. Чупин, А. О. Клишина. - DOI 10.25513/1812-3988.2019.17(3).39-47 // Вестник Омского университета. Серия: Экономика. - 2019. - Т. 17, № 3. - С. 39-47. URL: http://journal.omeco.ru/ru/archive/doc/2019_03.pdf\#page=39 (дата обращения: 17.11.2020). - Рез. англ.

28. Воловская, Н. М. Безработица как социально значимая проблема в России / Н. М. Воловская, Л. К. Плюснина // Общество: социология, психология, педагогика. 2016. - № 6. - C. 9-12. - URL: http://dom-hors.ru/rus/files/arhiv_zhurnala/spp/2016/6/ sociology/volovskaya-plyusnina.pdf (дата обращения: 17.11.2020). - Рез. англ.

29. Дубовских, К. И. Анализ взаимосвязи безработицы и ВВП в РФ / К. И. Дубовских, А. А. Смирнова // Приложение математики в экономических и технических исследованиях. - 2014. - № 1 (4). - C. 78-82. - URL: https://www.elibrary.ru/item. asp? id=21703305 (дата обращения: 17.11.2020). - Рез. англ.

Поступила 19.01.2021; одобрена после рецензирования 22.03.2021; принята к публикации 30.03.2021.

\section{Об авторе:}

Курило Анна Евгеньевна, ведущий научный сотрудник отдела моделирования и прогнозирования регионального развития Института экономики - обособленного подразделения Федерального исследовательского центра «Карельский научный центр Российской академии наук» (185030, Российская Федерация, г. Петрозаводск, пр. А. Невского, д. 50), доктор экономических наук, доцент, ORCID: https://orcid. org/0000-0002-7222-7832, akurilo@mail.ru

Автор прочитал и одобрил окончательный вариант рукописи.

\section{REFERENCES}

1. Stiglitz J.E., Ocampo J.A., Spiegel Sh., French-Davis R., Nayyar D. Stability with Growth. Macroeconomics, Liberalization, and Development. Oxford. New York: Oxford University Press; 2006. Available at: http://www.library.fa.ru/files/Stiglitz-Stability.pdf (accessed 21.10.2020). (In Eng.)

2. Pohlan L. Unemployment and Social Exclusion. Journal of Economic Behavior and Organization. 2019; 164:273-299. (In Eng.) DOI: https://doi.org/10.1016/j.jebo.2019.06.006 
3. Grant A.L. The Great Recession and Okun's Law. Economic Modelling. 2018; 69:291-300. (In. Eng.) DOI: https://doi.org/10.1016/j.econmod.2017.10.002

4. Benos N., Stavrakoudis A. Okun's Law: Copula-Based Evidence from G7 Countries. The Quarterly Review of Economics and Finance. 2020. (In. Eng.) DOI: https://doi. org/10.1016/j.qref.2020.10.004

5. Kitov I., Kitov O. Modeling Unemployment and Employment in Advanced Economies: Okun's Law with a Structural Fracture. Theoretical and Practical Research in Economic Fields. 2012; 3(1):26-41. Available at: https://journals.aserspublishing.eu/tpref/article/ view/1167 (accessed 21.10.2020). (In Eng.)

6. Dinu M., Marinaş M.C., Socol C., Socol G. Testing of the Okun's Law in Romania. Economic Computation and Economic Cybernetics Studies. 2011; (1):5-20. Available at: http://www.ecocyb.ase.ro/12011\%20pdf/marin\%20dinu.pdf (accessed: 21.10.2020). (In Eng.)

7. Simionescu M. Improving Unemployment Rate Forecasts at Regional Level in Romania Using Google Trends. Technological Forecasting and Social Change. 2020; 155. (In Eng.) DOI: https://doi.org/10.1016/j.techfore.2020.120026

8. Jin Zh., Harper A. Okun's Law: An Empirical Test Using Brazilian Data. Research in Business and Economics Journal. 2019; 13. Available at: https://scholar.valpo.edu/cba_fac $\mathrm{pub} / 72 /$ (accessed 21.10.2020). (In Eng.)

9. Akram M., Hussain Sh., Raza S.H., Masood S. An Empirical Estimation of Okun's Law in Context of Pakistan. Journal of Finance and Economics. 2014; 2(5):173-177. (In Eng.) DOI: https://doi.org/10.12691/jfe-2-5-7

10. Kangasharju A., Tavera Ch., Nijkamp P. Regional Growth and Unemployment: The Validity of Okun's Law for the Finnish Regions. Spatial Economic Analysis. 2012; 7(3):381-395. (In Eng.) DOI: https://doi.org/10.1080/17421772.2012.694141

11. Porras-Arena M.S., Martín-Románc Á.L. Self-Employment and the Okun's Law. Economic Modelling. 2019; 77:253-265. (In Eng.) DOI: https://doi.org/10.1016/j.econmod.2018.09.006

12. Guisinger A.Y., Hernandez-Murillo R., Owyang M.T., Sinclair T.M. A State-Level Analysis of Okun's Law. Regional Science and Urban Economics. 2018; 68:239-248. (In Eng.) DOI: https://doi.org/10.1016/j.regsciurbeco.2017.11.005

13. Akhundova O.V., Korovkin A.G., Korolev I.B. Interrelation of GDP Dynamics and Unemployment: A Theoretical and Practical Analysis. Nauchnye trudy: Institut narodnokhozyajstvennogo prognozirovaniya $R A N=$ Scientific Works: Institute for National Economic Forecasting of the RAS. 2005; 3:471-495. Available at: https://ecfor.ru/publication/vzaimosvyaz-dinamiki-vvp-i-bezrabotitsy/ (accessed 21.10.2020). (In Russ.)

14. Vakulenko E.S., Gurvich E.T. The Relationship of GDP, Unemployment Rateand Employment: In-Depth Analysis of Okun's Law for Russia. Voprosy ehkonomiki = Economic Issues. 2015; (3):5-27. (In Russ., abstract in Eng.) DOI: https://doi.org/10.32609/00428736-2015-3-5-27

15. Bakanach O.V., Proskurina N.V. Statistical Analysis of Unemployment in the Russian Federal Districts. Sistemnoe upravlenie = System Management. 2016; (2):4-11. Available at: http://sisupr.mrsu.ru/2016-2/PDF/Bakanach.pdf (accessed 21.10.2020). (In Russ., abstract in Eng.) 
16. Ramazanov D.I. The Relationship of Unemployment and Gross Regional Product in Ivanovo Region: Experience of Empirical Analysis. Sovremennye naukoemkie tekhnologii. Regionalnoe prilozhenie $=$ Modern High Technologies. Regional Application . 2019; 58(2):92-98. Available at: http://journals.isuct.ru/snt/article/view/1504 (accessed 21.10.2020). (In Russ., abstract in Eng.)

17. Promakhina I.M., Wang L. Econometric Analysis of Interdependence between Economic Growth and Unemployment in China (1978-2006). Vestnik Rossijskogo universiteta druzhby narodov. Seriya: Ehkonomika = RUDN Journal of Economics. 2008; (3):82-94. Available at: http://journals.rudn.ru/economics/article/view/12280 (accessed 21.10.2020). (In Russ., abstract in Eng.)

18. Druzhinin P.V. Moroshkina M.V. Assessment of the Development Efficiency of the European North Regions Based on Production Functions. Drukerovskij vestnik. 2019; (5):218-231. (In Russ., abstract in Eng.) DOI: https://doi.org/10.17213/2312-6469-2019-5217-231

19. Kurilo A.E., Prokopyev E.A. Development of E-Government in Russia: Advantages, Barriers and Prospects. Problemy rynochnoj ehkonomiki = Market Economy Problems. 2019; (4):15-27. (In Russ., abstract in Eng.) DOI: https://doi.org/10.33051/2500-23252019-4-015-027

20. Toksanbayeva M.S. The Scale, Factors and Mobility and Stability Motives in the Labour Market. Uroven zhizni naseleniya regionov Rossii = Living Standards of the Population in the Regions of Russia. 2019; (2):35-42. (In Russ., abstract in Eng.) DOI: https://doi. org/10.24411/1999-9836-2019-10062

21. Bakusheva G.V. Econometric Analysis of the Educational Factors Influence on the Russia's Regional Unemployment Rate. Khronoehkonomika = Chronoeconomics. 2019; (3):6-14. Available at: http://hronoeconomics.ru/journal_3.html (accessed 17.11.2020). (In Russ., abstract in Eng.)

22. Popov A.V., Soloveva T.S. Analyzing and Classifying the Implications of Employment Precarization: Individual, Organizational and Social Levels. Economic and Social Changes: Facts, Trends, Forecast. 2019; 12(6):182-196. (In Eng.) DOI: https://doi. org/10.15838/esc.2019.6.66.10

23. Bartlin E.A. The Economic Mechanism of the State Employment Policy in Russia. Uroven zhizni naseleniya regionov Rossii = Living Standards of the Population in the Regions of Russia. 2018; (2):78-85. (In Russ., abstract in Eng.) DOI: https://doi.org/10.24411/19999836-2018-10017

24. Gimpelson V.E., Kapeliushnikov R.I., Sharunina A.V. Low Paid Jobs in the Russian Labour Market: Does Exit Exist and Where Does It Lead to? Ehkonomicheskij zhurnal VSHE = Higher School of Economics Economic Journal. 2018; 22(4):489-530. (In Russ., abstract in Eng.) DOI: https://doi.org/10.17323/1813-8691-2018-22-4-489-530

25. Brzezinski A. Synergies in Labour Market Institutions: the Nonlinear Effect of Minimum Wages on Youth Employment. Atlantic Economic Journal. 2017; 45:251-263. (In Eng.) DOI: https://doi.org/10.1007/s11293-017-9537-7

26. Belov V.I., Bikkulova A.R. The Problem of Unemployment in Russia and Ways to Solve it. Meridian = Meridian. 2020; (3):9-11. Available at: http://meridian-journal.ru/site/ article?id=2732 (accessed 17.11.2020). (In. Russ., abstract in Eng.) 
27. Karpov V.V., Petrenko K.V., Chupin R.I., Klishina A.O. Unemployment as an Indicator of Economic Security of the Region. Vestnik Omskogo universiteta. Seriya "Ehkonomika" = Herald of Omsk University. Series "Economics". 2019; 17(3):39-47. (In Russ., abstract in Eng.) DOI: https://doi.org/10.25513/1812-3988.2019.17(3).39-47

28. Volovskaya N.M. Plyusnina L.K. Unemployment as a Socially Significant Problem in Russia. Obshchestvo: sotsiologiya, psikhologiya, pedagogika = Society: Sociology, Psychology, Pedagogics. 2016; (6):9-12. Available at: http://dom-hors.ru/rus/files/arhiv zhurnala/spp/2016/6/sociology/volovskaya-plyusnina.pdf (accessed 17.11.2020). (In Russ., abstract in Eng.)

29. Dubovskikh K.I., Smirnova A.A. Analysis of the Relationship of Unemployment and GDP in Russia. Prilozhenie matematiki v ehkonomicheskikh i tekhnicheskikh issledovaniyakh = Application of Mathematics in Economic and Technical Studies. 2014; (1):78-82. Available at: https://www.elibrary.ru/item.asp?id=21703305 (accessed 17.11.2020). (In Russ., abstract in Eng.)

Submitted 19.11.2021; approved after reviewing 22.03.2021; accepted for publication 30.03.2021.

About the author:

Anna E. Kurilo, Leading Researcher, Department of Modeling and Forecasting Regional Development, Institute of Economics, Karelian Research Centre of the Russian Academy of Sciences (50 A. Nevskogo Ave., Petrozavodsk 185030, Russian Federation), Dr. Sci. (Economics), Associate Professor, ORCID: https://orcid.org/0000-0002-7222-7832, akurilo@mail.ru

The author has read and approved the final version of the manuscript. 
УДК 316.344:616.853

DOI: $10.15507 / 2413-1407.115 .029 .202102 .447-469$

Оригинальная статья / Original article http://regionsar.ru

ISSN 2587-8549 (Print)

ISSN 2413-1407 (Online)

\section{Поселенческое неравенство и социальная эксклюзия людей с эпилепсией}

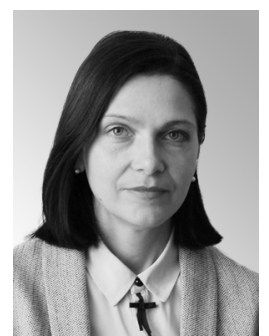

Н. П. Касаткина ${ }^{1,2}$

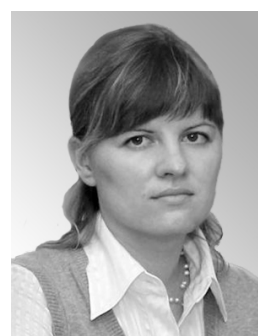

Н. В. Шумкова ${ }^{2 *}$

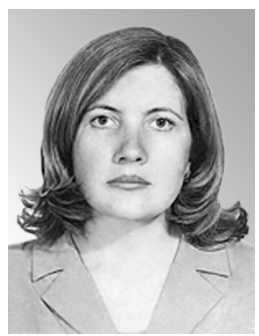

Н. Г. Токарева ${ }^{2}$

${ }^{1}$ ГКУ РМ «Научный изентр социально-экономического мониторинга» (2. Саранск, Российская Федераиия)

2 ФГБОУ ВО «МГУ им. Н. П. Огарёва» (г. Саранск, Российская Федераиия), *niiregion@mail.ru

Введение. Больные эпилепсией в силу наличия заболевания относятся к депривированным социальным группам. Результаты многих исследований подтверждают дискриминацию больных эпилепсией по разным социальным параметрам: доступности качественной лекарственной помощи, получения образования и рабочих мест. Поселенческий фактор усугубляет депривированное положение больных эпилепсией, что существенно влияет на их социально-психологическое самочувствие. Цель статьи - на основе материалов социологического исследования выявить связь между особенностями места проживания больного эпилепсией, показателями социальной эксклюзии и уровнем эмоционально-волевых и когнитивных расстройств.

Материалы и методы. Материалами для исследования послужили данные опроса 157 больных эпилепсией, состоящих на учете в психоневрологических диспансерах г. Пензы, г. Саранска и г. Алатыря. Опрос проведен по авторскому инструментарию в мае - декабре 2020 г. методом формализованного интервью. Результаты обработаны с использованием методов математической статистики в пакете программ SPSS.

Результаты исследования. Данные опроса подтверждают стигматизированность и депривацию больных эпилепсией: они реже вступают в брак, ограничены в возможности получения профессионального образования, чаще не имеют работы. Поселенческий фактор проявляется в неравном доступе к современным методам лечения эпилепсии и лекарственного обеспечения, инклюзивным образовательным программам и возможностям профессионально-трудовой социализации. Кластерный анализ данных позволил выделить три группы респондентов, существенно отличающихся по показателям и степени социальной эксклюзии: «образовательная депривация», «исключение на рынке труда» и «совладание со стигмой». Анализ указанных категорий с точки зрения

(C) Касаткина Н. П., Шумкова Н. В., Токарева Н. Г., 2021

Контент доступен под лицензией Creative Commons Attribution 4.0 License. This work is licensed under a Creative Commons Attribution 4.0 License. 
поселенческого фактора показывает, что доля наиболее депривированных групп находится в обратной зависимости от численности населения изучаемых городов.

Обсуждение и заключение. Формулируются выводы о том, что доступность механизмов социальной интеграции снижает вероятность развития негативных последствий заболевания, а соответствующие возможности во многом обусловлены размерами города. Полученные данные могут быть использованы для выделения категорий пациентов, имеющих сходные социальные проблемы, что позволит более целенаправленно осуществлять эмоциональную и инструментальную поддержку больных эпилепсией с учетом поселенческого фактора.

Ключевые слова: эпилепсия, социальная эксклюзия, стигматизация, рынок труда, система образования, регион, поселенческий фактор, депривация

Авторы заявляют об отсутствии конфликта интересов.

Финансирование. Статья подготовлена при финансовой поддержке РФФИ в рамках научного проекта «Факторы социальной эксклюзии в формировании психических расстройств у больных эпилепсией» (№ 20-013-00529 А).

Для циттирования: Касаткина, Н. П. Поселенческое неравенство и социальная эксклюзия людей с эпилепсией / Н. П. Касаткина, Н. В. Шумкова, Н. Г. Токарева. - DOI 10.15507/24131407.115.029.202102.447-469 // Регионология. - 2021. - Т. 29, № 2. - С. 447-469.

\title{
Settlement Inequality and Social Exclusion of People with Epilepsy
}

\author{
N. P. Kasatkina ${ }^{a, b}$, N. V. Shumkova ${ }^{b^{*}}$, N. G. Tokareva ${ }^{\text {b }}$ \\ a Scientific Center for Social and Economic Monitoring (Saransk, Russian Federation) \\ ${ }^{b}$ National Research Mordovia State University (Saransk, Russian Federation), \\ *niiregion@mail.ru
}

Introduction. Patients with epilepsy, due to the presence of the chronic disorder, belong to deprived social groups. The results of many studies confirm the discrimination of patients with epilepsy on various social parameters, such as the availability of high-quality medical care, education and jobs. The settlement factor aggravates the deprived situation of patients with epilepsy and significantly affects their socio-psychological well-being. Based on the materials of the study conducted, the article identifies the interconnection between the characteristics of the place of residence of a patient with epilepsy, indicators of social exclusion, and the level of emotional-volitional and cognitive disorders.

Materials and Methods. The data from a survey of 157 patients with epilepsy registered in neuropsychiatric dispensaries in Penza, Saransk, and Alatyr were used as materials for the study. The survey was conducted using the authors' tools in May - December 2020 as formalized interviews. The results were processed using mathematical statistics methods in the SPSS software package.

Results. The survey data have confirmed the stigmatization and deprivation of patients with epilepsy: they are less likely to marry, have limited opportunities for vocational education, and are more often unemployed. The settlement factor manifests itself in the unequal availability of modern medical services and provision of drugs, inclusive educational programs and opportunities for occupational socialization. The performed cluster analysis of the data has made it possible to single out three groups of respondents that differ significantly in terms of indicators and the degree of social exclusion: "educational deprivation", "exclusion in the labor market" and "coping with stigma". Analysis of these categories regarding the settlement factor shows that the share of the most deprived groups is inversely related to the population of the cities under study. 
Discussion and Conclusion. The authors have drawn the conclusions that the availability of social integration mechanisms reduces the likelihood of developing negative consequences of epilepsy, and the corresponding opportunities are largely due to the size of the city. The data obtained can be used to identify categories of patients with similar social problems, which will facilitate more targeted emotional and instrumental support for patients with epilepsy, with regard to the settlement factor.

Keywords: epilepsy, social exclusion, stigmatization, labor market, education system, region, settlement factor, deprivation

The authors declare that there is no conflict of interest.

Funding. The article was done with the financial support from the Russian Foundation for Basic Research as part of the scientific project "Social exclusion factors in the formation of mental disorders in patients with epilepsy" (No. 20-013-00529 A).

For citation: Kasatkina N.P., Shumkova N.V., Tokareva N.G. Settlement Inequality and Social Exclusion of People with Epilepsy. Regionology = Russian Journal of Regional Studies. 2021; 29(2):447-469. DOI: https://doi.org/10.15507/2413-1407.115.029.202102.447-469

Введение. Проблема социальной эксклюзии больных эпилепсией в современной российской действительности достаточно актуальна, о чем свидетельствуют данные научных исследований и упоминания соответствующих проблем в публичном дискурсе.

Больные эпилепсией - социальная группа с высоким риском относительной депривации. Многочисленные исследования свидетельствуют об ограничениях в различных сферах жизнедеятельности. Несмотря на отсутствие существенных физических и психологических нарушений, многие сталкиваются с барьерами, связанными с получением образования, трудоустройством, построением карьеры, созданием семьи. Ограничения в доступе к основным механизмам социальной интеграции провоцируют развитие депрессивного синдрома и, в конечном счете, ведут к инвалидизации, существенно ограничивающей социальные связи и снижающей качество жизни [1].

Доминирующими факторами формирования социальных барьеров для больных эпилепсией являются стигматизация, распространенность негативных социальных стереотипов, навешивание ярлыков. Эти социокультурные феномены воспроизводятся в образовательной, профессиональной, трудовой сферах общества и определяют дискриминацию этой социальной группы по признаку заболевания.

В то же время на неравенство людей с эпилепсией влияют факторы объективного характера. К ним, в частности, относится поселенческая дифференциация общества. В современной российской действительности с выраженным социально-экономическим различием территорий неравенство в зависимости от места проживания становится существенным фактором социального исключения.

Гипотезой статьи является предположение о том, что место проживания больного эпилепсией определяет степень его социальной эксклюзии 
и становится предиктором негативных последствий заболевания. Цель статьи - по результатам проведенного исследования выявить взаимосвязь между факторами социального неравенства больных с эпилепсией и выраженностью негативных последствий заболевания (эмоционально-волевые, когнитивные расстройства).

Обзор литературы. В зарубежной и отечественной литературе подчеркивается первоочередность социальных и психологических факторов течения заболевания у больных эпилепсией.

По мнению Л. И. Вассермана, В. А. Михайлова и С. Д. Табулиной, «социальные и психологические проблемы для больных эпилепсией нередко являются более серьезными, чем припадки и другие пароксизмальные проявления болезни» ${ }^{1}$.

Стигматизированность - ключевая характеристика эпилепсии как заболевания. Провести исчерпывающий анализ социального положения и качества жизни больных эпилепсией без учета этой составляющей вряд ли возможно. Многочисленные исследования из разных научных областей фиксируют взаимосвязи между особым самосознанием больных, специфическим отношением к ним общества и их социальным положением и качеством жизни. Наличие стигмы отчетливо свидетельствует о социальной эксклюзии, поскольку «идентификация и способность выделения “чужих"... лежит в основе этого феномена» [2, с. 5].

Стигматизация является значимым предиктором негативного течения болезни [3]. Выявляется прямая зависимость между воспринимаемой стигмой, качеством жизни и эффективностью лечения пациента. Так, высокий уровень самостигматизации отрицательно влияет на «управление режимами лечения и соблюдение режима приема лекарств» [4]. Кроме того, скрывая свое состояние, больные усугубляют течение своей болезни и делают ситуацию опасной не только для себя, но и для своего окружения.

Стигма возникает в результате столкновения с реальными эпизодами дискриминации из-за наличия нежелательного признака (например, судорог) или из-за постоянной боязни столкнуться с дискриминацией (об этом в своих публикациях пишут В. А. Михайлов [5], Г. В. Тюменкова ${ }^{2}$, Х. Дж. Ли с соавторами [6]). Стигматизация и самостигматизация объясняют низкие показатели брака и фертильности людей с эпилепсией [7], высокий уровень безработицы или неполной занятости [8], невысокий уровень материального благосостояния, проблемы с получением образования [9; 10] по сравнению с населением в целом.

В научной литературе проанализировано несколько сценариев, по которым может пойти процесс внутренней (личной) стигматизации (самостигматизации).

\footnotetext{
${ }^{1}$ Вассерман Л. И., Михайлов В. А., Табулина С. Д. Психологическая структура качества жизни больных эпилепсией. Пособие для врачей. СПб.: Психоневролог. инс-т им. В. М. Бехтерева, 2008. C. 89-95.

${ }^{2}$ Тюменкова Г. В. Стигматизация больных эпилепсией: автореф. дисс. ... канд. мед. наук. М., 2003. $21 \mathrm{c}$.
} 
Для тех, кому диагноз был поставлен в детском возрасте, основными предикторами стигматизации становятся семейные факторы, в частности высокая тревожность родителей [11]. По мнению исследователей, реакция родителей на заболевание закладывает основу для интерпретации заболевания ребенком [12]. Отрицательная реакция учит ребенка думать об эпилепсии как о чемто постыдном, беспокоиться по поводу враждебной реакции окружающих и, соответственно, скрывать свое заболевание. При манифестации заболевания во взрослом возрасте главной причиной самостигматизации служит основная деятельность (учеба в вузе или работа) и взаимоотношения в группе [13].

Самостигматизация при эпилепсии способствует формированию комплекса личностной деформации. У больных отмечается преобладание конформных установок, плохой самоконтроль и высокая напряженность, склонность переносить ответственность за собственные неудачи на других лиц, социальная незрелость личности, негативное отношение в сферах достижений, производственных и межличностных отношений․

Механизмы формирования внешней стигматизации связаны с особенностями общественного сознания. Распространение социальных стереотипов (это «упрощенный, односторонний, крайне утрированный образ определенной группы, трактующий всех членов этой группы недифференцированно, независимо от их индивидуальных особенностей ${ }^{4}$ ) влияет на негативное отношение общества к больным эпилепсией. Расхожим является мнение, что люди с эпилепсией имеют поведенческие, личностные отклонения либо умственную отсталость. Очень часто такие стереотипы в виде предрассудков и суеверий закреплены в культурных традициях и обычаях тех или иных стран $[14 ; 15]$ и во многом обусловлены низкой информированностью населения об особенностях заболевания ${ }^{5}[16]$.

Недостаток информации в отношении причин, методов лечения и первой помощи во время приступа эпилепсии присутствует у большинства людей, причем «плохая осведомленность о болезни не связана с полом, образованием, продолжительностью эпилепсии, но зависит от страны проживания» $[17$, с. 79]. С. В. Томас и А. Наир считают, что при системном решении проблемы стигматизации больных эпилепсией необходимо учитывать контекстуальный характер стигмы и принимать во внимание ее страновые и региональные особенности, обусловленные разницей экономических условий, культурных особенностей, медицинских практик, гендерных ролей и т. д. [18].

${ }^{3}$ Токарева Н. Г. Эпилепсия и стигматизация // Наука и инновации в современном мире: медицина и фармацевтика, биология, сельское хозяйство, география и геология (Коллективная монография). Одесса, 2017. С. 103-112.

${ }^{4}$ Штомпка П. Социология. Анализ современного общества: пер. с польск. С. М. Червонной. М.: Логос, 2005. С. 316.

${ }^{5}$ Caveness W. F., Gallup Jr G. H. A Survey of Public Attitudes Toward Epilepsy in 1979 with an Indication of Trends over the Past Thirty Years // Epilepsia. 1980. Vol. 21, issue 5. Pp. 509-518. DOI: https://doi.org/10.1111/j.1528-1157.1980.tb04302.x 
Наряду с выявлением стигматизированности, данные исследований свидетельствуют о социальной депривации больных эпилепсией. Особенно распространена дискриминация на рынке труда. Например, согласно эстонским исследованиям, лишь около 30 \% опрошенных лиц с эпилепсией были трудоустроены на полный рабочий день. Более половины (62 \%) тех, кто оказался безработным или частично занятым, уверены, что их эпилепсия является важной причиной сложившейся ситуации, 44 \% указали на случаи дискриминации на рабочем месте или при попытке устроиться на работу [19].

Дискриминация имеет законодательное закрепление и влияет на качество жизни людей, страдающих эпилепсией. Правовые ограничения имеют длительную историю и предполагают широкий спектр запретов: на занятость в отдельных видах деятельности (наиболее распространены), на брак, рождение детей, иммиграцию и т. д. От некоторых из них в отдельных странах отказались совсем недавно. Наиболее обсуждаемым в публикациях является вопрос о праве на вождение автомобиля, отсутствие либо ограничение которого воспринимается как дискриминирующий фактор $[20 ; 21]$.

Таким образом, многочисленные данные подтверждают социальное исключение (эксклюзию) больных эпилепсией. Выделяются как объективные, так и субъективные составляющие этого процесса. К первым относятся ограничение доступа к общественным благам, барьеры в сферах образования и трудоустройства. Причем некоторые исследователи отмечают, что степень неравенства возможностей людей с эпилепсией зависит от социально-экономического потенциала территории проживания, обеспечивающего диверсифицированность рынка рабочих мест и доступность качественных медицинских и образовательных услуг [22-24]. На фоне депривации запускаются субъективные факторы - самостигматизация и самоэксклюзия - самоотречение от существующих возможностей, что усугубляет социально-психологическое положение больных эпилепсией.

Роль социального исключения в развитии психосоциальных проблем больных эпилепсией обнаруживается по косвенным данным - из публикаций, в большинстве посвященных медико-психологической тематике. Отдельных исследований, касающихся оценки влияния доступности образования, трудоустройства, медицинских услуг на социальное самочувствие больных с эпилепсией, особенно в поселенческом аспекте, пока недостаточно.

Материалы и методы. Эмпирическую базу исследования составили данные формализованных интервью пациентов с эпилепсией ${ }^{6}$, проведенных в трех городах Приволжского федерального округа - г. Пензе (520 тыс. чел. населения, областной центр, Пензенская область), г. Саранске (320 тыс.,

${ }^{6}$ Опрашивались лишь пациенты с легкими и умеренными нарушениями когнитивной и эмоционально-волевой сфер. Пациенты с выраженными когнитивными нарушениями были исключены из выборки. 
столица, Республика Мордовия) и г. Алатыре (34 тыс., райцентр, Чувашская Республика) - среди пациентов психоневрологических диспансеров (2020, $\mathrm{n}=157)$.

В структуре выборки представлены пациенты в возрасте от 18 до 58 лет $(\mathrm{M}=37,7 ; \mathrm{DP}=10,7) ; 57 \%$ - мужчины. Большинство опрошенных (53\%) никогда не состояли в браке, $28 \%$ - находятся в разводе; $61 \%$ - не имеют детей. Показатель медианного возраста начала приступов колеблется в диапазоне от 11 до 20 лет; 35 \% опрошенных сообщили, что находятся в состоянии ремиссии. Большинство респондентов имеют основное общее (неполное среднее) и начальное профессиональное образование (24 и $35 \%$ соответственно), $23 \%$ - официально зарегистрированы как безработные, 38 \% - пенсионеры (в том числе по инвалидности). Многие (57 \%) оценивают материальное положение своей семьи как «среднее», имея среднемесячный доход на одного человека около 10000 руб.

Исследование осуществлялось с помощью авторского опросника, состоявшего из двух блоков. В рамках «психологического блока» проводился сбор данных по методикам определения когнитивной («Таблица Шульте», «Корректурная проба», «Красно-черная таблица», «10 слов», «Память на образы», «Пиктограмма», «Выделение существенных признаков», «Исключение понятий», «Толкование пословиц», тест Равена) и эмоционально-волевой сфер (шкала депрессии Бека (BDI), шкала тревоги Цунга (ZARS), торонтская шкала алекситимии (TAS)). «Социологический блок» был ориентирован на выявление параметров социальной эксклюзии людей с эпилепсией.

Полученные результаты исследования обрабатывались с помощью программного пакета IBM SPSS Statistics 21. Применялись процедуры дескриптивного и многомерного статистического анализа.

Результаты исследования. Сложная территориальная организация российского общества является объективным фактором социальной дифференциации. Территориальные общности в силу выраженных региональных диспропорций различаются по доступности материальных и нематериальных благ. Очевидно, что влияние поселенческого фактора в отношении людей с эпилепсией будет более значительным в силу их ограниченных адаптационных возможностей.

Основным индикатором социального положения и качества жизни является уровень доходов. Полученные данные свидетельствуют об экономическом неравенстве больных с эпилепсией в зависимости от региона проживания. Наиболее высокий ежемесячный доход имеют жители г. Пензы (более 11000 руб.), в то время как у большинства жителей г. Алатыря (45\%) он составляет от 8500 до 11000 руб., а у жителей г. Саранска он еще ниже и не превышает 8500 руб. (57 \%). Поэтому депривацию из-за материального статуса чаще испытывают жители г. Саранска. Это также следует из самооценки материального благополучия больных: доля негативно оценивающих 
свое материальное положение (как плохое или очень плохое) в г. Саранске составляет $50 \%$, в г. Алатыре - $35 \%$, в г. Пензе $-18 \%$.

Более высокий уровень дохода в г. Алатыре и г. Пензе связан, во-первых, с высоким уровнем инвалидизации и соответственно пенсионным обеспечением по инвалидности (II и III группы), во-вторых, с занятостью на рынке труда. Респонденты, проживающие в г. Саранске, находятся в более затруднительном положении, поскольку у них нет источника стабильного дохода: они не имеют инвалидности и в то же время не работают (доля неработающих выше (79 \%), чем среди жителей других рассматриваемых городов) (табл. 1).

Т а б л и ц а 1. Распределение ответов на вопросы анкеты в зависимости от места проживания респондентов, \%

$\mathrm{T}$ a $\mathrm{b} 1 \mathrm{e} 1$. Distribution of answers to the survey questions depending on the place of residence of the respondents, \%

\begin{tabular}{l|c|c|c}
\hline \multicolumn{1}{c|}{ Вариант ответа / Answer option } & $\begin{array}{c}\text { Алатырь / } \\
\text { Alatyr }\end{array}$ & $\begin{array}{c}\text { Пенза / } \\
\text { Penza }\end{array}$ & $\begin{array}{c}\text { Саранск / } \\
\text { Saransk }\end{array}$ \\
\hline \multicolumn{2}{c}{ Paбomaeme ли Bbl? / Are you employed? } \\
Работают или учатся / Work or study & - & 33 & 21 \\
Не работают / Do not work & 100 & 67 & 79 \\
Итого / Total & 100 & 100 & 100 \\
Имеете ли Bbl групnу инвалидности? / Do you have a disability category? \\
Да, II группа / Yes, disability group 2 & 90 & 35 & 50 \\
Да, III группа / Yes, disability group 3 & 10 & 28 & 29 \\
Нет / No & - & 37 & 21 \\
Итого / Total & 100 & 100 & 100
\end{tabular}

Показатели занятости прямо пропорционально растут в зависимости от величины города. В сравнительно малочисленном, не имеющем статуса административного центра г. Алатыре ни один из опрошенных не указал на статус работающего или учащегося. Доля занятых в г. Саранске составила 21 \%, а в наиболее многочисленном г. Пензе - 33 \%. Следовательно, рынок труда в крупных городах создает благоприятные условия для трудоустройства больных эпилепсией, имеющих невысокие в силу заболевания шансы на трудоустройство.

Поселенческие различия наблюдаются в стратегиях управления заболеванием. Среди опрошенных в г. Пензе больше тех, кто носит карточку (жетон) о своем заболевании, знакомы с принципами кетагенной диеты, придерживаются здорового образа жизни (не курят (65\%), стараются больше двигаться), чаще ведут дневник приступов, организовывают пространство и соблюдают режим дня.

Важным фактором социального и психологического самочувствия больных эпилепсией является доступность современных лекарственных средств 
и новых технологий лечения. Согласно полученным данным, респонденты отличаются по качеству проводимой медикаментозной терапии. Больные эпилепсией из выборки г. Алатыря получают монотерапию, продолжая принимать традиционные противоэпилептические препараты предыдущего поколения (карбамазепин, бензонал), имеющие побочные эффекты в виде расстройства со стороны ЦНС (усталость, головокружение) и когнитивных нарушений (памяти, внимания, зрительного восприятия).

При лечении пациентов в г. Саранске и г. Пензе наряду с монотерапией используется комбинированная терапия - противоэпилептические препараты в сочетании с ноотропами, анксиолитиками, нейролептиками. Наряду с традиционными препаратами предыдущего поколения (карбамазепин, бензонал, фенобарбитал) применяются препараты нового поколения: окскарбазепин, трилептал, кеппра, которые коррелируют с более высокой эффективностью и переносимостью терапии.

Таким образом, качество жизни респондентов, проживающих в г. Пензе, по ряду параметров выше, чем в двух других рассматриваемых городах. Контроль за заболеванием, современная лекарственная терапия, информированность о методах профилактики приступов, ориентация на здоровый образ жизни, по всей вероятности, обусловлены не только более высоким качеством оказываемой медицинской, социально-психологической помощи в указанном регионе. Важная роль принадлежит вовлеченности больных эпилепсией в сферу общественно-полезного труда.

Для выявления поселенческих особенностей социальной эксзклюзии людей с эпилепсией проведена кластеризация ${ }^{7}$ множественных ответов респондентов на вопрос «Послужила ли Ваша болезнь причиной...». В результате были получены кластеры, объединяющие группы респондентов, различающихся по степени интеграции в систему социального взаимодействия. Для первого кластера наиболее важным предиктором являлся выбор ответа «проблемы с образованием» (96 \%); второй кластер характеризуется выбором таких вариантов ответа, как «потеря работы» $(100 \%)$ и «инвалидность» $(100 \%)$; третий кластер - отсутствием значимых проблем в сфере обучения (0\%) и трудоустройства $(0 \%)$.

По сути выявленные кластеры показывают распространенность трех моделей социального исключения, которые условно можно обозначить как «образовательная депривация» (31\%), «исключение на рынке труда» (32%), «совладание со стигмой» (37\%).

${ }^{7}$ Для типологизации больных эпилепсией использовался метод двухэтапного кластерного анализа в программе IBM SPSS Statistics 21. Входные поля: закодированные с помощью дихотомических переменных ответы «потеря семьи», «отсутствие детей», «проблемы с образованием», «потеря работы», «инвалидность» на вопрос «Послужила ли Ваша болезнь причиной...». Расстояние между средними из полученных трех кластеров говорит об их хорошем качестве, что подтверждает силуэтная мера связанности и разделения кластеров (выше 0,5$)$. 
В таблице 2 приведены ответы представителей трех кластеров на вопросы анкеты, касающиеся различных аспектов социального статуса больных эпилепсией.

Т а б л и ц а 2. Распределение ответов на вопросы анкеты в зависимости от кластерной принадлежности, \%

$\mathrm{T}$ a $\mathrm{b} 1 \mathrm{e} 2$. Distribution of answers to the survey questions depending on cluster affiliation, $\%$

\begin{tabular}{|c|c|c|c|c|}
\hline Показатель / Indicator & $\begin{array}{l}\text { Образовательная } \\
\text { депривация / } \\
\text { Educational } \\
\text { deprivation }\end{array}$ & \begin{tabular}{|c|} 
Исключение \\
на рынке \\
труда / \\
Labor market \\
exclusion \\
\end{tabular} & $\begin{array}{l}\text { Совладание } \\
\text { со стигмой / } \\
\text { Coping with } \\
\text { stigma }\end{array}$ & $\begin{array}{c}\text { Вся } \\
\text { выборка / } \\
\text { Whole } \\
\text { sample } \\
(\mathrm{n}=157) \\
\end{array}$ \\
\hline 1 & 2 & 3 & 4 & 5 \\
\hline $\begin{array}{l}\text { Доля женщин, \% / Share } \\
\text { of women, \% }\end{array}$ & 53 & 31 & 46 & 43 \\
\hline $\begin{array}{l}\text { Boзраст, медиана / Age, } \\
\text { median }\end{array}$ & 40 & 40 & 33 & 37 \\
\hline \multicolumn{5}{|c|}{ Место жительства / Place of residence } \\
\hline Алатырь, \% / Alatyr, \% & 25 & 33 & 9 & 22 \\
\hline Саранск, \% / Saransk, \% & 41 & 45 & 51 & 46 \\
\hline Пенза, \% / Penza, \% & 34 & 21 & 40 & 32 \\
\hline \multicolumn{5}{|c|}{ Статус больного / Status of the patient } \\
\hline $\begin{array}{l}\text { Как давно поставлен } \\
\text { диагноз, лет, медиана / } \\
\text { How long ago the } \\
\text { diagnosis was given, } \\
\text { years, median }\end{array}$ & 22 & 18 & 9 & 17 \\
\hline $\begin{array}{l}\text { Инвалидность I-II } \\
\text { группы, \% / Disability } \\
\text { groups } 1-2, \%\end{array}$ & 59 & 77 & 26 & 53 \\
\hline $\begin{array}{l}\text { Без инвалидности, \% / } \\
\text { No disability, \% }\end{array}$ & 16 & - & 31 & 16 \\
\hline $\begin{array}{l}\text { Ремиссия, \% / } \\
\text { Remission, \% }\end{array}$ & 14 & 43 & 46 & 35 \\
\hline \multicolumn{5}{|c|}{ Доход / Income } \\
\hline $\begin{array}{l}\text { Ежемесячный доход, } \\
\text { руб., медиана / Monthly } \\
\text { income, rubles, median }\end{array}$ & 9000 & 8400 & 10300 & 9100 \\
\hline $\begin{array}{l}\text { Субъективная оценка } \\
\text { материального } \\
\text { благосостояния как } \\
\text { «хорошего», \% / } \\
\text { Subjective assessment } \\
\text { of material well-being as } \\
\text { "good", \% }\end{array}$ & 2 & - & 25 & 9 \\
\hline
\end{tabular}


Продолжение табл. 2 / Continuation of table 2

\begin{tabular}{|c|c|c|c|c|}
\hline 1 & 2 & 3 & 4 & 5 \\
\hline \multicolumn{5}{|c|}{ Cемейный статус / Family status } \\
\hline $\begin{array}{l}\text { Не состоят в браке, \% / } \\
\text { Single, } \%\end{array}$ & 69 & 22 & 67 & 53 \\
\hline $\begin{array}{l}\text { Состоят в браке, \% / } \\
\text { Married, \% }\end{array}$ & 2 & 28 & 26 & 19 \\
\hline $\begin{array}{l}\text { Разведены, \% / } \\
\text { Divorced, \% }\end{array}$ & 27 & 51 & 7 & 28 \\
\hline Нет детей, \% / No & 76 & 33 & 74 & 61 \\
\hline
\end{tabular}

Образование / Education

Высшее

- 4

18

8

профессиональное

образование, \% / Higher

vocational education, $\%$

Среднее

8

49

32

30

профессиональное

образование, \% /

Secondary vocational

education, $\%$

Неполное

46

45

18

35

профессиональное

образование, \% /.

Incomplete vocational

education, $\%$

Неполное среднее

образование, \% /

46

26

24

Incomplete secondary

education, $\%$

Работа по найму на

государственном

предприятии, \% /

Employment in a state-

owned enterprise, $\%$

Ведение домашнего

хозяйства, \% /

Housekeeping, \%

Пенсионер (в том числе

по инвалидности), \% /

Pensioner (including

disability pensioners), $\%$

Безработный, \% /

Unemployed, \%

Занятость / Employment

8

19

10

4

29

21

19

45

45

25

38 
Продолжение табл. 2 / Continuation of table 2

\begin{tabular}{|c|c|c|c|c|}
\hline 1 & 2 & 3 & 4 & 5 \\
\hline \multicolumn{5}{|c|}{ Психологические характеристики / Psychological characteristics } \\
\hline $\begin{array}{l}\text { Изменения } \\
\text { личности, \% / Personality } \\
\text { change, \% }\end{array}$ & 88 & 84 & 57 & 76 \\
\hline $\begin{array}{l}\text { Умеренные нарушения } \\
\text { интеллекта, \% / Moderate } \\
\text { intellectual disability, \% }\end{array}$ & 90 & 72 & 56 & 72 \\
\hline $\begin{array}{l}\text { Умеренные нарушения } \\
\text { мышления, \% / Moderate } \\
\text { thought disorder, \% }\end{array}$ & 90 & 73 & 54 & 71 \\
\hline $\begin{array}{l}\text { Снижение памяти, \% / } \\
\text { Memory decline, \% }\end{array}$ & 94 & 100 & 65 & 85 \\
\hline $\begin{array}{l}\text { Снижение внимания, \% / } \\
\text { Decreased attention, \% }\end{array}$ & 81 & 100 & 84 & 88 \\
\hline $\begin{array}{l}\text { Тревожность, \% / } \\
\text { Anxiety, \% }\end{array}$ & 75 & 82 & 84 & 81 \\
\hline $\begin{array}{l}\text { Выраженная степень } \\
\text { дисфории, \% / Severe } \\
\text { dysphoria, \% }\end{array}$ & 18 & - & - & 6 \\
\hline $\begin{array}{l}\text { Депрессия, \% / } \\
\text { Depression, \% }\end{array}$ & 57 & 20 & 42 & 40 \\
\hline
\end{tabular}

Здоровый образ жизни / Healthy lifestyle

Занимается

4

физкультурой, \% /

$-$
Engaged in physical
exercise, $\%$

Ведет сидячий образ

жизни, \% / Leads

$\begin{array}{llll}51 & 31 & 25 & 35\end{array}$

a sedentary lifestyle, \%

Ведет дневник

приступов, \% / Keeps

a diary of seizures, $\%$

Выполняет все

51

66

56

предписания врача, \% /

Complies with all the

doctor's prescriptions, $\%$

Tрудовая сфера / Labor sphere

Считает условия 18

своего труда фактором

возникновения

болезни, \% / Consider the conditions of their work as a factor in the onset of the disease, $\%$ 
Продолжение табл. 2 / Continuation of table 2

\begin{tabular}{l|c|c|c|c}
\hline 1 & 2 & $\mathbf{3}$ & 4 & 5 \\
\hline $\begin{array}{l}\text { Существуют проблемы } \\
\text { с сохранением работы, }\end{array}$ & 41 & $\mathbf{8 0}$ & 42 & 54 \\
повышением на & & & \\
paбoтe, \% / There are \\
problems with keeping \\
a job and promotion, \%
\end{tabular}

Семейные отношения и личная жизнь / Family relationships and personal life

Устраивают

сложившиеся

взаимоотношения

с родственниками,

живущими отдельно, \% /

Satisfied with the

established relationships

with relatives living

separately, \%

Устраивают сложившиеся взаимоотношения с друзьями, \% / Satisfied with the established relationships with friends, $\%$

Устраивают

69

51

Чувствуют себя

наиболее комфортно

в кругу семьи, \% / Feel

most comfortable in the

family circle, $\%$

Количество совместно

проживающих

с больным членов семьи, чел., медиана / Number

of the family members

living with the patient, people, median

Всегда предупреждают

друзей, знакомых

о возможности

приступа, \% / Always

warn friends and acquaintances about the

possibility of an attack, $\%$

25

51

42

39

49

96

65

70

77

45

\section{сложившиеся \\ взаимоотношения \\ с домочадцами, \% /
Satisfied with the existin
relationships with the
household members, \% \\ с домочадцами, \% /
Satisfied with the existing
relationships with the
household members, \% \\ с домочадцами, \% /
Satisfied with the existin
relationships with the
household members, \% \\ с домочадцами, \% /
Satisfied with the existin
relationships with the
household members, \%}


Окончание табл. 2 / End of table 2

\begin{tabular}{l}
\hline \multicolumn{1}{c}{1} \\
\hline Предупреждают друзей, \\
знакомых \\
о возможности приступа \\
в исключительных \\
случаях, \% / Warn friends \\
and acquaintances about \\
the possibility of an attack \\
in exceptional cases, \%
\end{tabular}

Никогда не

предупреждают друзей, знакомых

о возможности приступа

в исключительных случаях, \% / Never warn friends and acquaintances about the possibility of an attack in exceptional cases, $\%$

Всегда предупреждают коллег о возможности приступа, \% / Always warn colleagues about the possibility of an attack, $\%$

Предупреждают коллег

о возможности приступа

в исключительных

случаях, \% / Warn

colleagues about the

possibility of an attack in

exceptional cases, $\%$

Никогда не

предупреждают коллег

о возможности приступа

в исключительных

случаях, \% / Never warn

colleagues about the

possibility of an attack in

exceptional cases, $\%$

Примечание / Note. Полужирным шрифтом в таблице выделены значения стандартизированных остатков $>1,65$, курсивом - значения $<-1,65$ / In the table, the values of standardized residuals $>1.65$ are in bold, and the values $<-1.65$ are italicized.

Большинство респондентов (96 \%) из кластера «образовательная дискриминация» сообщили, что имели проблемы с образованием: 46 \% получили лишь неполное среднее, $46 \%$ - начальное профессиональное образование. На возможность получения образования, вероятно, оказала влияние ранняя 
манифестация заболевания (в возрасте до перехода из школы в систему профессионального образования). Многие не имеют своей семьи (69 \% - холостые или незамужние), не имеют детей (73 \%), не заняты трудовой деятельностью (45 \% - получают пенсию по инвалидности, 20 \% - безработные).

Ограниченность социальных контактов и ориентация на социальную изоляцию, проблемы во взаимоотношениях с близким окружением свидетельствуют о депрессии и анозогностическом отношении к своему заболеванию: опрошенные не занимаются физкультурой, не ведут дневник приступов, не прислушиваются к рекомендациям врача. На высокий уровень социальной изоляции указывают ответы на вопрос «Предупреждаете ли вы друзей, знакомых о возможности приступа?» - 29 \% представителей этого кластера выбирают ответ «никогда» (в среднем по выборке такой вариант отметили 16 \% респондентов).

Таким образом, селективность института образования приводит к раннему выталкиванию больных с эпилепсией из образовательной системы, что сводит к минимуму возможности формирования социальных навыков, развития когнитивной сферы и консервирует социально-психологические проблемы. Эта категория респондентов отличается сравнительно более выраженными когнитивными и эмоционально-поведенческими нарушениями. Этот факт актуализирует проблему реализации инклюзивных программ обучения для разных категорий населения.

Особенности группы респондентов, именуемой как «исключение на рынке труда», связаны с доступностью рабочих мест и возможностями формирования трудовой карьеры. Представители этого кластера - преимущественно мужчины (69 \%) со средним (49 \%) или начальным (45 \%) профессиональным образованием. В их случае заболевание стало причиной потери работы (100\%), так как содержание труда, судя по характеру их образования связанное с физической нагрузкой и травмоопасными условиями, противоречило требованиям к условиям и содержанию труда этой категории больных. Экономическая дезадаптация ввиду проблем с занятостью, ограничение возможности для поддержания материального статуса, вероятно, могли стать фактором потери собственной семьи (51 \% разведены).

Опыт социального взаимодействия поспособствовал формированию сети социальных связей (друзей и знакомых), которая для респондентов выступает значительной поддержкой. Отсутствие эмоциональных отклонений может свидетельствовать о гармоничном отношении к заболеванию, что выражается в контроле над болезнью (ведут дневник приступов). Особенности социально-профессионального статуса представителей этой группы респондентов показывают, что наиболее значительные барьеры на пути их социального продвижения выстраивает рынок труда. Для этой категории опрошенных характерны когнитивные нарушения (памяти, внимания), в то же время расстройства эмоциональной сферы отсутствуют. 
Особенности третьего кластера заключаются в реализации стратегии «совладания со стигмой», направленной на повышение социального статуса, получение образования и трудоустройство. Представители этого кластера чаще, чем в других группах, имеют высшее образование (18\% против 8 \%) и сравнительно более низкий показатель инвалидизации (53\%). Поскольку большинство трудоустроены (преимущественно в сферах интеллектуального труда), то субъективная и объективная оценки собственного материального положения выше, чем в других категориях (на материальное положение как хорошее указали $25 \%$ против $9 \%$ в среднем по массиву).

Материальный статус является одним из факторов благоприятного микроклимата в семье (69 \% устраивают взаимоотношения с домочадцами, $51 \%$ чувствуют себя наиболее комфортно в кругу семьи). Данная категория характеризуется отсутствием выраженных когнитивных и эмоциональноповеденческих нарушений, высоким уровнем контроля над заболеванием (ведут дневник приступов, соблюдают предписания врача, занимаются физкультурой). Эта группа опрошенных предпочитает скрывать заболевание, что связано с ориентацией на сохранение социального статуса и опасениями возможной негативной реакции окружающих. Они склонны сообщать о своем заболевании лишь в исключительных случаях, причем такой позиции придерживаются как в отношении коллег (42 \% против $30 \%$ в среднем по выборке), так и друзей (39 \% против 29 \%). Подобная стратегия сокрытия болезни требует от них повышенного эмоционального усилия и приводит к стрессу и тревожности.

Анализ представленности рассматриваемых групп респондентов в исследуемых городах еще раз подтверждает социальное неравенство территориальных общностей. Социальная дифференциация депривированных групп, к которым относятся больные эпилепсией, в проекции поселенческого фактора проявляется еще более отчетливо. Характерные для них проблемы доступа к каналам социальной мобильности более отчетливо отражают недостатки в развитии механизмов социальной интеграции.

Адаптивные сценарии, способствующие вовлечению больных с эпилепсией в общественную жизнь, получают распространение в благополучных по численности населения, развитости рынка труда и системы образования городах. Так, доля респондентов, чей статусный набор отражает сценарий социальной интеграции, последовательно снижается в зависимости от численности населения города: в г. Пензе - 43 \%, в г. Саранске - 39 \%, в г. Алатыре $-14 \%$. В то же время распространенность сценария исключения на рынке труда наиболее высока в г. Алатыре (50\%); в г. Саранске и г. Пензе она составляет 33 и $21 \%$ соответственно.

Обсуждение и заключение. Результаты исследования коррелируют с данными зарубежных и отечественных авторов. Подтверждается наличие стигмы, самостигматизации и социальной эксклюзии людей с эпилепсией. 
Глубина социальной эксклюзии зависит от уровня образования, имеющегося у больного эпилепсией, от возможностей использования современных технологий и методов лечения, лекарственного обеспечения. Наиболее доступным для данной категории больных является среднее профессиональное образование. Однако построение карьеры по полученной профессии осложняется проблемами с трудоустройством и сохранением занятости. Заболевание становится основной причиной потери работы, а экономическая дезадаптация в свою очередь - фактором развития проблем в семейной сфере, вплоть до распада брака.

Анализ влияния поселенческого фактора показал дифференциацию больных эпилепсией по доступности качественного образования, медицинского обслуживания и рабочих мест. Чем выше показатели социально-экономического развития места проживания респондента, и, соответственно, уровень развития институтов социальной интеграции, тем выше шансы больных эпилепсией получить образование, современную медикаментозную терапию и возможность трудоустроится, что является ведущим фактором снижения инвалидизации, когнитивных и эмоциональных расстройств.

Полученные результаты подтверждают обоснованность применения концепции многомерного функционального диагноза к изучению эпилепсии, сформулированной в рамках биопсихосоциальной парадигмы современной психиатрии. Концепция предполагает триединый подход к анализу особенностей заболевания каждого конкретного пациента: рассмотрение во взаимосвязи клинико-биологических, психологических и социальных параметров. Исследование выявило связь между особенностями социального статуса больного, ресурсами его социальной поддержки и имеющимися у него психосоциальными проблемами.

Возможности экстраполяции полученных выводов ограничены, поскольку они основываются на результатах опроса в населенных пунктах с невысоким уровнем жизни и экономическими показателями. В связи с этим перспективным является изучение факторов социальной эксклюзии в регионах с более радикальными отличиями в уровне экономического развития и развития институциональной среды, например, в крупных агломерациях. Работа представляет интерес для специалистов, занимающихся проблемами социального неравенства, социальной эксклюзии людей с инвалидностью.

\section{СПИСОК ИСПОЛЬЗОВАННЫХ ИСТОЧНИКОВ}

1. Безух, С. М. Компетенции социального работника в вопросах сопровождения людей, страдающих эпилепсией / С. М. Безух // Ученые записки Санкт-Петербургского государственного института психологии и социальной работы. -2011 . - Т. 16, № 2. C. 15-18. - URL: https://notes.psysocwork.ru/fileadmin/user_upload/UZ_2011-2_03.pdf (дата обращения: 28.01.2021). - Рез. англ 
2. Бородкин, Ф. М. Социальные эксклюзии / Ф. М. Бородкин // Социологический журнал. - 2000. - № 3-4. - C. 5-17. - URL: https://www.jour.fnisc.ru/index.php/socjour/ article/view/644 (дата обращения: 28.01.2021).

3. Tombini, M. Depressive Symptoms and Difficulties in Emotion Regulation in Adult Patients with Epilepsy: Association with Quality of Life and Stigma / M. Tombini, G. Assenza, L. Quintiliani. - DOI 10.1016/j.yebeh.2020.107073 // Epilepsy \& Behavior. - 2020. - Vol. 107. - URL: https://www.sciencedirect.com/science/article/pii/ S1525505020302523?via\%3Dihub (дата обращения: 28.01.2021).

4. Jacoby, A. Social Stigma for Adults and Children with Epilepsy / A. Jacoby, J. K. Austin. - DOI 10.1111/j.1528-1167.2007.01391.x // Epilepsia. - 2007. - Vol. 48. - Pp. 6-9. URL: https://onlinelibrary.wiley.com/doi/full/10.1111/j.1528-1167.2007.01391.х (дата обращения: 28.01.2021).

5. Михайлов, В. А. Актуальные вопросы эпилептологии - стигматизация, качество жизни и реабилитация больных / В. А. Михайлов // Эпилепсия и пароксизмальные состояния. - 2010. - Т. 2, № 3. - C. 39-44. - URL: https://www.epilepsia.su/jour/article/ view/195/223 (дата обращения: 28.01.2021). - Рез. англ.

6. Risk and Protective Factors Related to Stigma Among People with Epilepsy: An Integrative Review / H. J. Lee, E. K. Choi, H. B. Park, S.-H. Yang. - DOI 10.1016/j.yebeh.2020.106908 // Epilepsy \& Behavior. - 2020. - Vol. 104. - URL: https://www.sciencedirect.com/science/article/pii/S1525505019311023?via\%3Dihub (дата обращения: 28.01.2021).

7. Социальная адаптация и качество жизни женщин репродуктивного возраста, страдающих эпилепсией / Д. В. Дмитренко, Н. А. Шнайдер, Ю. Б. Говорина, А. В. Муравьева. - DOI 10.14412/2074-2711-2015-3-15-20 // Неврология, нейропсихиатрия, психосоматика. - 2015. - Т. 7, № 3. - C. 15-20. - URL: https://nnp.ima-press.net/nnp/ article/view/525 (дата обращения: 28.01.2021). - Рез. англ.

8. Stigmatization and Social Impacts of Epilepsy in Turkey / P. D. Ak, D. Atakli, B. Yuksel [et al.]. - DOI 10.1016/j.yebeh.2015.05.014 // Epilepsy \& Behavior. 2015. - Vol. 50. - Pp. 50-54. - URL: https:/www.sciencedirect.com/science/article/pii/ S1525505015002656?via\%3Dihub (дата обращения: 28.01.2021).

9. Reilly, C. Academic Achievement in Children with Epilepsy: A Review / C. Reilly, B. G. R. Neville. - DOI 10.1016/j.eplepsyres.2011.07.017 // Epilepsy Research. - 2011. Vol. 97, issue 1-2. - Pp. 112-123. - URL: https://www.sciencedirect.com/science/article/ pii/S0920121111002208?via\%3Dihub (дата обращения: 28.01.2021).

10. Predictors of High School Dropout, Anxiety, and Depression in Genetic Generalized Epilepsy / M. Syvertsen, S. Vasantharajan, T. Moth [et al.]. - DOI 10.1002/epi4.12434 // Epilepsia Open. - 2020. - Vol. 5, issue 4. - Pp. 611-615. - URL: https://onlinelibrary.wiley. com/doi/10.1002/epi4.12434 (дата обращения: 28.01.2021).

11. Academic Problems in Children with Seizures: Relationships with Neuropsychological Functioning and Family Variables During the 3 Years after Onset / D. W. Dunn, C. S. Johnson, S. M. Perkins. - DOI 10.1016/j.yebeh.2010.08.023// Epilepsy \& Behavior. - 2010. - Vol. 19, issue 3. - Pp. 455-461. - URL: https://www. sciencedirect.com/science/article/pii/S1525505010005767?via\%3Dihub (дата обращения: 28.01.2021). 
12. Mendes, T. P. Family Cohesion, Stigma, and Quality of Life in Dyads of Children with Epilepsy and their Parents / T. P. Mendes, C. A. Crespo, J. K. Austin. - DOI 10.1093/jpepsy/jsw105 // Journal of Pediatric Psychology. - 2017. - Vol. 42, issue 6. Pp. 689-699. - URL: https://academic.oup.com/jpepsy/article/42/6/689/2964570 (дата обращения: 28.01.2021).

13. Григорьева, И. А. Факторы, влияющие на стигматизацию пациентов с эпилепсией / И. А. Григорьева, Л. А. Троицкая. - DOI 10.14412/2074-2711-2015-1S-10-14 // Неврология, нейропсихиатрия, психосоматика. - 2015. - T. 7, № 1S. - C. 10-14. - URL: https:/nnp.ima-press.net/index.php/nnp/article/view/467 (дата обращения: 28.01.2021).

14. Ismail, H. South Asians and Epilepsy: Exploring Health Experiences, Needs and Beliefs of Communities in the North of England / H. Ismail, J. Wright, P. Rhodes. - DOI 10.1016/j.seizure.2005.08.006 // Seizure. - 2005. - Vol. 14, issue 7. - Pp. 497-503. - URL: https:/www.sciencedirect.com/science/article/pii/S1059131105001494?via\%3Dihub (дата обращения: 28.01.2021).

15. A Community Survey of Knowledge, Perceptions, and Practice with Respect to Epilepsy Among Traditional Healers in the Batibo Health District, Cameroon / A. K. Njamnshi, A.-C. Zoung-Kanyi Bissek, F. N. Yepnjio [et al.]. - DOI 10.1016/j.yebeh.2009.10.018 // Epilepsy Behavior. - 2010. - Vol. 17, issue 1. - Pp. 95-102. - URL: https://www.sciencedirect.com/science/article/pii/S1525505009006003?via\%3Dihub (дата обращения: 28.01.2021).

16. Knowledge, Stigma, and Quality of Life in Epilepsy: Results before and after a Community-Based Epilepsy Awareness Program in Rural Bolivia / L. Giuliano, C. E. Cicero, S. Padilla [et al.]. - DOI 10.1016/j.yebeh.2018.11.036 // Epilepsy \& Behavior. 2019. - Vol. 92. - Pp. 90-97. - URL: https://www.sciencedirect.com/science/article/pii/ S1525505018307765?via\%3Dihub (дата обращения: 28.01.2021).

17. Парфенова, Е. В. Социокультурные аспекты и различные виды стигматизации при эпилепсии / Е. В. Парфенова, Ф. К. Ридер, А. Г. Герсамия. - DOI 10.14412/20742711-2018-1S-89-95 // Неврология, нейропсихиатрия, психосоматика. - 2018. - Т. 10, № 1S. - C. 89-95. - URL: https://nnp.ima-press.net/nnp/article/view/915 (дата обращения: 28.01.2021). - Рез. англ.

18. Thomas, S. V. Confronting the Stigma of Epilepsy / S. V. Thomas, A. Nair. - DOI 10.4103/0972-2327.85873 // Annals of Indian Academy of Neurology. - 2011. - Vol. 14, issue 3. - Pp. 158-163. - URL: https:/www.ncbi.nlm.nih.gov/pmc/articles/PMC3200035/ (дата обращения: 28.01.2021).

19. Epilepsy in Estonia: A Quality-of-Life Study / M. Herodes, A. Õun, S. Haldr, A.-E. Kaasik. - DOI 10.1046/j.1528-1157.2001.0420081061.x // Epilepsia. - 2001. Vol. 42, issue 8. - Pp. 1061-1073. - URL: https:/onlinelibrary.wiley.com/doi/full/10.1046/ j.1528-1157.2001.0420081061.x (дата обращения: 28.01.2021).

20. Beran, R. G. Some Legal Aspects of Epilepsy / R. G. Beran, J. A. Devereaux, D. Buchanan. - DOI 10.1016/j.yebeh.2020.107244 // Epilepsy \& Behavior. - 2020. - Vol. 111. URL: https://www.sciencedirect.com/science/article/pii/S1525505020304236?via\%3Dihub (дата обращения: 28.01.2021).

21. Baker, G. A. The Psychosocial Burden of Epilepsy / G. A. Baker. - DOI 10.1046/j.1528-1157.43.s.6.12.x // Epilepsia. - 2002. - Vol. 43, issue 6. - Pp. 26-30. - URL: 
https:/onlinelibrary.wiley.com/doi/full/10.1046/j.1528-1157.43.s.6.12.х (дата обращения: 28.01.2021).

22. Epilepsy Prevalence and Socioeconomic Deprivation in England / S. Steer, W. O. Pickrell, M. P. Kerr, R. H. Thomas. - DOI 10.1111/epi.12763 // Epilepsia. - 2014. Vol. 55, issue 10. - Pp. 1634-1641. - URL: https://onlinelibrary.wiley.com/doi/full/10.1111/ ері.12763 (дата обращения: 28.01.2021).

23. An Estimation of Global Volume of Surgically Treatable Epilepsy Based on a Systematic Review and Meta-Analysis of Epilepsy / K. A. Vaughan, C. Lopez Ramos, V. P. Buch [et al.]. - DOI 10.3171/2018.3.JNS171722 // Journal of Neurosurgery. - 2018. - Vol. 130, issue 4. - Pp. 1127-1141. - URL: https://thejns.org/view/journals/j-neurosurg/130/4/article-p1127.xml (дата обращения: 28.01.2021).

24. Magnusson C. High-Resolution Mapping of Epilepsy Prevalence, Ambulance use, and Socioeconomic Deprivation in an Urban Area of Sweden / C. Magnusson, J. Zelano. - DOI 10.1111/epi.16339// Epilepsia. - 2019. - Vol. 60, issue 10. Pp. 2060-2067. - URL: https://onlinelibrary.wiley.com/doi/10.1111/epi.16339 (дата обращения: 28.01.2021).

Поступила 23.12.2020; одобрена после рецензирования 10.02.2021; принята к публикации 19.02.2021.

\section{Об авторах:}

Касаткина Наталья Петровна, ведущий научный сотрудник ГКУ РМ «Научный центр социально-экономического мониторинга» (430005, Российская Федерация, г. Саранск, ул. Б. Хмельницкого, д. 39a), доцент кафедры социологии ФГБОУ ВО «МГУ им. Н. П. Огарёва» (430005, Российская Федерация, г. Саранск, ул. Большевистская, д. 68/1), кандидат социологических наук, ORCID: https://orcid.org/0000-00020940-2087, kasatkina-rri@mail.ru

Шумкова Наталья Викторовна, доцент кафедры социологии ФГБОУ ВО «МГУ им. Н. П. Огарёва» (430005, Российская Федерация, г. Саранск, ул. Большевистская, д. 68/1), кандидат социологических наук, ORCID: https://orcid.org/0000-0002-2330-0028, niiregion@mail.ru

Токарева Наталья Геннадьевна, доцент кафедры нервных болезней и психиатрии ФГБОУ ВО «МГУ им. Н. П. Огарёва» (430005, Российская Федерация, г. Саранск, ул. Большевистская, д. 68/1), кандидат медицинских наук, ORCID: https:/orcid. org/0000-0002-2974-8149, tokareva-1@mail.ru

Заявленный вклад авторов:

Н. П. Касаткина - разработка методологии исследования; анализ литературы по проблеме исследования; подготовка текста статьи.

Н. В. Шумкова - первичная интерпретация статистических данных; анализ литературы по проблеме исследования; подготовка текста статьи.

Н. Г. Токарева - сбор и обработка данных; критический анализ и доработка текста.

Авторы прочитали и одобрили окончательный вариант рукописи. 


\section{REFERENCES}

1. Bezukh S.M. Social Worker's Competencies in Issues of the Support of People with Epilepsy. Uchenye zapiski Sankt-Peterburgskogo gosudarstvennogo instituta psikhologii i sotsialnoj raboty $=$ Scientific Notes Journal of St. Petersburg State Institute of Psychology and Social Work. 2011; 16(2):15-18. Available at: https://notes.psysocwork. ru/fileadmin/user_upload/UZ_2011-2_03.pdf (accessed 28.01.2021). (In Russ., abstract in Eng.)

2. Borodkin F.M. Social Exclusions. Sotsiologicheskij zhurnal = Sociological Journal. 2000; (3-4):5-17. Available at: https://www.jour.fnisc.ru/index.php/socjour/article/view/644 (accessed 28.01.2021). (In Russ.)

3. Tombini M., Assenza G., Quintiliani L. Depressive Symptoms and Difficulties in Emotion Regulation in Adult Patients with Epilepsy: Association with Quality of Life and Stigma. Epilepsy \& Behavior. 2020; 107. (In Eng.) DOI: https://doi.org/10.1016/j.yebeh.2020.107073

4. Jacoby A., Austin J.K. Social Stigma for Adults and Children with Epilepsy. Epilepsia. 2007; 48:6-9. (In Eng.) DOI: https://doi.org/10.1111/j.1528-1167.2007.01391.x

5. Mikhailov V.A. Topical Issues of Epileptology - Stigmatization, Quality of Life and Rehabilitation of Patients. Ehpilepsiya $i$ paroksizmalnye sostoyaniya $=$ Epilepsy and Paroxysmal Conditions. 2010; 2(3):39-44. Available at: https://www.epilepsia.su/jour/article/ view/195/223 (accessed: 28.01.2021). (In Russ., abstract in Eng.)

6. Lee H.J. Choi E.K., Park H.B., Yang S.-H. Risk and Protective Factors Related to Stigma Among People with Epilepsy: An Integrative Review. Epilepsy \& Behavior. 2020; 104. (In Eng.) DOI: https://doi.org/10.1016/j.yebeh.2020.106908

7. Dmitrenko D.V., Shnayder N.A., Govorina Yu.B., Muravieva A.V. Social Adaptation and Quality of Life in Reproductive-Aged Women with Epilepsy. Nevrologiya, nejropsikhiatriya, psikhosomatika = Neurology, Neuropsychiatry, Psychosomatics. 2015; 7(3):1520. (In Russ., abstract in Eng.) DOI: https://doi.org/10.14412/2074-2711-2015-3-15-20

8. Ak P.D., Atakli D., Yuksel B., et al. Stigmatization and Social Impacts of Epilepsy in Turkey. Epilepsy \& Behavior. 2015; 50:50-54. (In Eng.) DOI: https://doi.org/10.1016/j. yebeh.2015.05.014

9. Reilly C., Neville B.G.R. Academic Achievement in Children with Epilepsy: A Review. Epilepsy Research. 2011; 97(1-2):112-123. (In Eng.) DOI: https://doi.org/10.1016/j. eplepsyres.2011.07.017

10. Syvertsen M., Vasantharajan S., Moth T., et al. Predictors of High School Dropout, Anxiety, and Depression in Genetic Generalized Epilepsy. Epilepsia Open. 2020; 5(4):611-615. (In Eng.) DOI: https://doi.org/10.1002/epi4.12434

11. Dunn D.W., Johnson C.S., Perkins S.M. Academic Problems in Children with Seizures: Relationships with Neuropsychological Functioning and Family Variables during the 3 Years after Onset. Epilepsy \& Behavior. 2010; 19(3):455-461. (In Eng.) DOI: https://doi. org/10.1016/j.yebeh.2010.08.023

12. Mendes T.P., Crespo C.A., Austin J.K. Family Cohesion, Stigma, and Quality of Life in Dyads of Children with Epilepsy and their Parents. Journal of Pediatric Psychology. 2017; 42(6):689-699. (In Eng.) DOI: https://doi.org/10.1093/jpepsy/jsw105 
13. Grigoryeva I.A., Troitskaya L.A. Factors Influencing the Stigmatization of Patients with Epilepsy. Nevrologiya, nejropsikhiatriya, psikhosomatika = Neurology, Neuropsychiatry, Psychosomatics. 2015; 7(1S):10-14. (In Russ., abstract in Eng.) DOI: https://doi. org/10.14412/2074-2711-2015-1S-10-14

14. Ismail H., Wright J., Rhodes P. South Asians and Epilepsy: Exploring Health Experiences, Needs and Beliefs of Communities in the North of England. Seizure. 2005; 14(7):497-503. (In Eng.) DOI: https://doi.org/10.1016/j.seizure.2005.08.006

15. Njamnshi A.K., Zoung-Kanyi Bissek A.-C., Yepnjio F.N., et al. A Community Survey of Knowledge, Perceptions, and Practice with Respect to Epilepsy among Traditional Healers in the Batibo Health District, Cameroon. Epilepsy Behavior. 2010; 17(1):95-102. (In Eng.) DOI: https://doi.org/10.1016/j.yebeh.2009.10.018

16. Giuliano L. Cicero C.E., Padilla S., et al. Knowledge, Stigma, and Quality of Life in Epilepsy: Results before and after a Community-Based Epilepsy Awareness Program in Rural Bolivia. Epilepsy \& Behavior. 2019; 92:90-97. (In Eng.) DOI: https://doi.org/10.1016/j. yebeh.2018.11.036

17. Parfenova E.V., Rider F.K., Gersamia A.G. Sociocultural Aspects and Different Types of Stigmatization in Epilepsy. Neurology, Neuropsychiatry, Psychosomatics. 2018; 10(1S):89-95. (In Russ., abstract in Eng.) DOI: https://doi.org/10.14412/2074-2711-2018$1 \mathrm{~S}-89-95$

18. Thomas S.V., Nair A. Confronting the Stigma of Epilepsy. Annals of Indian Academy of Neurology. 2011; 14(3):158-163. (In Eng.) DOI: https://doi.org/10.4103/09722327.85873

19. Herodes M., Õun A., Haldr S. Epilepsy in Estonia: A Quality-of-Life Study. Epilepsia. 2001; 42(8):1061-1073. (In Eng.) DOI: https://doi.org/10.1046/j.15281157.2001.0420081061.x

20. Beran R.G., Devereaux J.A., Buchanan D. Some Legal Aspects of Epilepsy. Epilepsy \& Behavior. 2020; 111. (In Eng.) DOI: https://doi.org/10.1016/j.yebeh.2020.107244

21. Baker G.A. The Psychosocial Burden of Epilepsy. Epilepsia. 2002; 43(6):26-30. (In Eng.) DOI: https://doi.org/10.1046/j.1528-1157.43.s.6.12.x

22. Steer S., Pickrell W.O., Kerr M.P., Thomas R.H. Epilepsy Prevalence and Socioeconomic Deprivation in England. Epilepsia. 2014; 55(10):1634-1641. (In Eng.) DOI: https:// doi.org/10.1111/epi.12763

23. Vaughan K.A., Lopez Ramos C., Buch V.P., et al. An Estimation of Global Volume of Surgically Treatable Epilepsy Based on a Systematic Review and Meta-Analysis of Epilepsy. Journal of Neurosurgery. 2018; 130(4):1127-1141. (In Eng.) DOI: https://doi. org/10.3171/2018.3.JNS171722

24. Magnusson C., Zelano J. High-Resolution Mapping of Epilepsy Prevalence, Ambulance use, and Socioeconomic Deprivation in an Urban Area of Sweden. Epilepsia. 2019; 60(10):2060-2067. (In Eng.) DOI: https://doi.org/10.1111/epi.16339

Submitted 23.12.2020; approved after reviewing 10.02.2021; accepted for publication 19.02.2021. 
About the authors:

Natalya P. Kasatkina, Leading Research Officer, Scientific Center for Social and Economic Monitoring (39a B. Khmelnitskogo St., Saransk 430005, Russian Federation); Associate Professor, Department of Sociology, National Research Mordovia State University (68/1 Bolshevistskaya St., Saransk 430005, Russian Federation), Cand. Sci. (Sociology), ORCID: https://orcid.org/0000-0002-0940-2087, kasatkina-rri@mail.ru

Natalya V. Shumkova, Associate Professor, Department of Sociology, National Research Mordovia State University (68/1 Bolshevistskaya St., Saransk 430005, Russian Federation), Cand. Sci. (Sociology), ORCID: https://orcid.org/0000-0002-2330-0028, niiregion@mail.ru

Natalya G. Tokareva, Associate Professor, Department of Nervous System Diseases and Psychiatry, National Research Mordovia State University (68/1 Bolshevistskaya St., Saransk 430005, Russian Federation), Cand. Sci. (Medicine), ORCID: https://orcid. org/0000-0002-2974-8149, tokareva-1@mail.ru

\section{Contribution of the authors:}

N. P. Kasatkina - elaboration of the research methodology; analysis of the literature on the research problem; writing the text of the article.

$\mathrm{N}$. V. Shumkova - primary interpretation of statistical data; analysis of the literature on the research problem; writing the text of the article.

N. G. Tokareva - collection and processing of data; critical analysis and revision of the text of the article.

The authors have read and approved the final version of the manuscript. 


\section{ИНФОРМАЦИЯ ДЛЯ АВТОРОВ И ЧИТАТЕЛЕЙ}

Редакция журнала «Регионология» публикует оригинальные научные исследования, посвященные актуальным проблемам региональной политики, экономики и социологии, анализу комплексного развития регионов Российской Федерации и зарубежных стран. Не допускается направление в редакцию уже опубликованных статей или статей, отправленных на публикацию в другие журналы. В случае обнаружения одновременной подачи рукописи в несколько изданий опубликованная статья будет ретрагирована (отозвана из печати). Мониторинг несанкционированного цитирования осуществляется с помощью систем «Антиплагиат» и CrossCheck.

Журнал приветствует статьи, имеющие потенциально высокий импакт-фактор и/или содержащие материал о значительных достижениях в указанных направлениях. Особое внимание следует уделить качеству перевода. Желательно, чтобы он был выполнен носителем английского языка.

При подготовке статьи к публикации в журнале «Регионология» необходимо учесть следующие пункты.

1. Указать УДК.

2. Заголовок статьи должен кратко и точно отражать содержание статьи, тематику и результаты проведенного исследования. Приводится на русском и английском языках.

3. Аннотация (200-250 слов.) выполняет функцию расширенного названия статьи и повествует о ее содержании. В ней должны быть четко обозначены следующие составные части:

1) Введение (Introduction);

2) Материалы и методы (Materials and Methods);

3) Результаты исследования (Results);

4) Обсуждение и заключение (Discussion and Conclusion).

Приводится на русском и английском языках.

4. Ключевые слова (5-10) являются поисковым образом научной статьи. В связи с этим они должны отражать основные положения, достижения, результаты, терминологию научного исследования. Приводятся на русском и английском языках.

5. Благодарности. В этом разделе следует упомянуть людей, помогавших автору подготовить настоящую статью, организации, оказавшие финансовую поддержку. Хорошим тоном считается выражение благодарности анонимным рецензентам. Приводятся на русском и английском языках.

6. Основной текст статьи излагается на русском или английском языках.

1) Введение - постановка научной проблемы, ее актуальность, связь с важнейшими задачами, которые необходимо решить, значение для развития определенной отрасли науки или практической деятельности.

2) Обзор литературы. Необходимо описать основные (последние по времени) исследования и публикации, на которые опирается автор; современные взгляды на проблему; трудности при разработке данной темы; выделить нерешенные вопросы в пределах общей проблемы, которым посвящена статья.

3) Материалы и методы. В данном разделе описываются процесс организации эксперимента, примененные методики, использованная аппаратура; даются подробные сведения об объекте исследования; указывается последовательность выполнения исследования и обосновывается выбор используемых методов (наблюдение, опрос, тестирование, эксперимент, лабораторный опыт и т. д.).

4) Результаты исследования. Это основной раздел, цель которого - при помощи анализа, обобщения и разьяснения данных доказать рабочую гипотезу (гипотезы). Результаты должны быть изложены кратко, но при этом содержать достаточно информации для оценки сделанных выводов. Также должно быть обосновано, почему 
для анализа были выбраны именно эти данные. Все названия, подписи и структурные элементы графиков, таблии, схем и т. д. оформляются на русском и английском языках. Рисунки могут быть представлены в растровом или векторном формате с разрешение не ниже $300 \mathrm{dpi}$. Они должны допускать перемещение в тексте и возможность изменения размеров. Все графические данные помещаются в текст статьи, а также высылаются дополнительно в виде отдельных файлов.

5) Обсуждение и заключение. В заключении суммируются результаты осмысления темы, делаются выводы, обобщения и рекомендации, вытекающие из работы, подчеркивается их практическая значимость, а также определяются основные направления для дальнейшего исследования в этой области.

7. Список использованных источников (оформляется в соответствии с требованиями ГОСТа Р 7.0.100-2018). Ссылаться нужно в первую очередь на оригинальные источники из научных журналов, включенных в глобальные индексы цитирования. Желательно использовать 30-40 источников. Из них за последние 3 года - не менее 20 , иностранных - не менее 15. Следует указать DOI или адрес доступа в сети Интернет. Оформляется на русском и английском языках.

8. Информация об авторах. Ф.И.О., организация(и), адрес организации(й) (требуется указать все места работы автора, в которых выполнялись исследования (постоянное место, место выполнения проекта и др.)), должность и ученое звание, ORCID ID, Researcher ID, Scopus ID, электронная почта, телефон, почтовый адрес для отправки авторского экземпляра. Приводится на русском и английском языках.

9. Вклад соавторов. В конец рукописи необходимо включить примечания, в которых разъясняется фактический вклад каждого соавтора в выполненную работу. Приводится на русском и английском языках.

10. Авторам необходимо прислать свое фото отдельным файлом для публикации в журнале - качественный лицевой портрет в формате *jpg или *tif с разрешением не менее 300 точек (формат 10х15 см).

При подаче статьи в редакцию автор соглашается с положениями прилагаемого лицензионного договора.

Важным этапом в процессе отбора статьи является рецензирование. В журнале «Регионология» принято «двойное слепое» (рецензент и автор не знают имен друг друга) рецензирование статей. Рецензент на основании анализа статьи принимает решение о рекомендации ее к публикации или о ее отклонении. В случае несогласия автора статьи с замечаниями рецензента его мотивированное заявление рассматривается редакционной коллегией.

Допускается свободное воспроизведение материалов журнала в личных целях и свободное использование в информационных, научных, учебных и культурных целях в соответствии со ст. 1273 и 1274 гл. 70 ч. IV Гражданского кодекса РФ. Иные виды использования возможны только после заключения соответствующих письменных соглашений с правообладателем.

Журнал распространяется по подписке, заявкам высших учебных заведений, учреждений образования и отдельных лиц. Подписной индекс -73335 .

Наименование журнала в базе данных Web of Science Core Collection (Emerging Sources Citation Index) - REGIONOLOGIYA-REGIONOLOGY RUSSIAN JOURNAL OF REGIONAL STUDIES.

Вдовин Сергей Михайлович - главный редактор. Тел.: +7 (8342) 24-48-88.

Полутин Сергей Викторович - заместитель главного редактора. Тел.: +7 (8342) 32-81-57. Гордина Светлана Викторовна - ответственный секретарь. Тел.: +7 (8342) 48-14-24. 


\section{INFORMATION FOR AUTHORS AND READERS OF THE JOURNAL}

Russian Journal of Regional Studies journal accepts previously unpublished original scientific papers devoted to topical issues of regional policy, economy and sociology, as well as to the analysis of the integrated development of the regions of the Russian Federation and other countries. It is not allowed to submit papers that have already been published or sent for publication to other journals. In case of multiple submission of a manuscript, the published article will be retracted. Monitoring of unauthorized citation is implemented by means of Antiplagiat and CrossCheck systems.

The Journal gives preference to the articles with potentially high impact factor and/ or containing materials about significant achievements in the specified areas of science. Special attention should be paid to the quality of the translation. Preferably it should be made by a native English speaker.

When preparing an article for publication in Russian Journal of Regional Studies, the following points should be taken into account.

1. It is necessary to indicate the Universal Decimal Classification (UDC) code.

2. The title of the article should accurately reflect the content of the article, the subject matter and the results of the research conducted.

The title should be written in Russian and English.

3. The abstract (200-250 words) serves as an enhanced title of the article and briefly presents its content. The abstract consists of the following components:

1) Introduction;

2) Materials and Methods;

3) Results;

4) Discussion and Conclusion.

The abstract should be written in Russian and English.

4. Keywords (5-10) make the search profile of the scientific article. In this regard, they should reflect the main provisions, achievements, results and terminology of the scientific research.

Keywords should be written in Russian and English.

5. Acknowledgements. In this section the author may mention the people who helped them to prepare the article or the organizations that provided financial support. It is considered good style to express gratitude to anonymous reviewers.

Acknowledgements should be written in Russian and English.

6. The main body of the article should be written in Russian or in English.

1) Introduction. It contains formulation of the scientific problem, its relevance, connection with the most important tasks to be solved, the importance for the development of a particular area of science or practical activities.

2) Literature review. It is necessary to describe the main (recent) pieces of research and publications relied upon by the author, modern views on the problem, difficulties in solving the problem as well as to highlight the unresolved issues within the general problem of the article.

3) Materials and methods. This section describes the process of designing the experiment, the methods and equipment used; it gives detailed information about the subject and sequence of the research, justifies the choice of the methods used (observation, survey, testing, experiment, etc.).

4) Results. This is the main section, the purpose of which is to prove the working hypothesis (hypotheses) by analyzing, generalizing and explaining the data. The results should be brief, but they should provide sufficient information to evaluate the conclusions drawn. It should also be justified why the particular data were chosen for the analysis. All names, signatures and structural elements of graphs, tables, diagrams, etc. should be written in Russian and English. Figures should be presented in a raster or vector format 
with a resolution of at least $300 \mathrm{dpi}$. It should be possible to move them in the text and resize them. All graphic data should be placed in the text of the article and also should be attached as separate files.

5) Discussion and conclusion. In conclusion, the results of understanding the topic should be summarized; conclusions, generalizations and recommendations arising from the work should be made, their practical significance should be emphasized and the main directions for further research in the studied area should be determined.

7. References should be given in accordance with the requirements of the GOST $R$ 7.0.100-2018 standard. The original sources from scientific journals included in the global citation indices should be cited first of all. It is desirable to refer to 30-40 sources. Of these, at least 20 sources should be those published over the past 3 years and at least 15 foreign ones. DOI or the URL of the source should be indicated.

References should be written in Russian and English.

8. Information about the author(s) includes: the author's first name and last name, the name of the institution and its address (it is required to specify all the institutions where the author works and where the research was conducted (permanent place of work, the place where the project was done, etc.)). The author's position and academic title, ORCID, Researcher ID, Scopus ID, e-mail, phone number, postal address for sending a personal copy of the Journal issue.

Information about the authors should be written in Russian and English.

9. Contribution of the authors. At the end of the manuscript, the authors should include notes that explain the actual contribution of each co-author to the work performed.

Contribution of the authors should be written in Russian and English.

10. Authors should send their photos as separate files for publication in the Journal. They should be good quality portraits in *jpg or *tiff format with a resolution of at least 300 dpi (10x15 cm format).

When submitting an article to the Journal, the author agrees with the provisions of the attached license agreement.

As part of the submission, the Journal will peer review your article before deciding whether to publish it. Russian Journal of Regional Studies uses double-blind review, which means that both the reviewer and author identities are concealed from the reviewers, and vice versa. On the basis of the analysis of the article, the reviewer makes a decision whether to recommend the article for publication or reject it. If the author disagrees with the reviewer's comments, their reasoned statement shall be considered by the Editorial Board.

Free reproduction of the Journal's materials for personal purposes and free use for information, scientific, educational and cultural purposes is allowed in accordance with articles 1273 and 1274 of Chapter 70, part 4 of the Civil Code of the Russian Federation. Other types of use are possible only after the conclusion of relevant written agreements with the right holder.

The Journal is distributed on the basis of a subscription, requests of higher education institutions, educational institutions and individuals. The subscription index is 73335 .

Name of the Journal in Web of Science Core Collection (Emerging Sources Citation Index) - REGIONOLOGIYA-REGIONOLOGY RUSSIAN JOURNAL OF REGIONAL STUDIES.

Sergey M. Vdovin - Editor-in-Chief. Tel.: +7 (8342) 244888.

Sergey V. Polutin - Deputy Editor-in-Chief. Tel.: +7 (8342) 328157.

Svetlana V. Gordina - Executive Editor. Tel.: +7 (8342) 481424. 


\section{РЕГИОНОЛОГИЯ REGIONOLOGY}

Редактор E. С. Суркова.

Компьютерная верстка Е. П. Гординой.

Перевод А. В. Пузакова.

Выпускающий (редактор по выпуску) Е. П. Гордина.

Информационная поддержка сайта журнала $A$. А. Парамонова.

Подписной индекс - 73335.

Территория распространения журнала: Российская Федерация, зарубежные страны

Журнал зарегистрирован в Федеральной службе по надзору в сфере связи, информационных технологий и массовых коммуникаций (Роскомнадзор). Свидетельство о регистрации средства массовой информации ПИ № ФС77-65932 от 06 июня 2016 г.

Подписано в печать 08.06.2021. Дата выхода в свет 30.06.2021. Формат 60x84 1/16. Усл. печ. л. 14,88. Тираж 1000 экз. I завод - 250 экз. Заказ № 663. Свободная цена.

Адрес редакиии: 430005, Российская Федерация, Республика Мордовия, г. Саранск, ул. Большевистская, д. 68/1.

Тел./факс: (8342) 48-14-24, (8342) 32-86-14.

E-mail: redreg@mrsu.ru, regionology@mail.ru

http://regionsar.ru

Адрес учредителя и издателя: 430005, Российская Федерация, Республика Мордовия, г. Саранск, ул. Большевистская, д. 68.

Адрес типографии: 430005, Российская Федерация, Республика Мордовия, г. Саранск, ул. Советская, д. 24 (Издательство федерального государственного бюджетного образовательного учреждения высшего образования «Национальный исследовательский Мордовский государственный университет им. Н. П. Огарёва»).

Фотографии предоставлены самими авторами и опубликованы с их согласия. 


\section{Russian Journal of Regional Studies}

\section{Editor E. S. Surkova.}

Desktop publishing by E. P. Gordina.

Translation by A. V. Puzakov.

Sub-editor E. P. Gordina.

Informational support of the Journal's website by A. A. Paramonov.

Subscription index -73335 .

The Journal is distributed in the Russian Federation and abroad.

The Journal is registered with the Federal Service for Supervision of Communications, Information Technology, and Mass Media (Roskomnadzor); mass media registration certificate: PI No. FS77-65932 of 6 June 2016.

Signed to print 08.06 .2021 . Date of publishing 30.06.2021. Sheet size $60 \times 841 / 16$. Conventional printed sheets 14.88. Number of copies: 1,000. Print run 1: 250 copies. Order No. 663. Open price.

Editorial office: 68/1 Bolshevistskaya St., Saransk 430005, Republic of Mordovia, Russian Federation.

Tel/Fax: +7 8342 481424, +7 8342328614

E-mail: redreg@mrsu.ru, regionology@mail.ru

http://regionsar.ru

Address of the Founder and Publisher: 68 Bolshevistskaya St., Saransk 430005, Republic of Mordovia, Russian Federation.

Address of the Printing House: 24 Sovetskaya St., Saransk 430005, Republic of Mordovia, Russian Federation (Publishing House of National Research Mordovia State University).

The photographs are provided by the authors and are published with their consent. 


\section{Уважаемые авторы и читатели! \\ Наименование журнала в базе данных Web of Science Core Collection (Emerging Sources Citation Index) - REGIONOLOGIYA-REGIONOLOGY RUSSIAN JOURNAL OF REGIONAL STUDIES}

Web of

Science Master Journal List

Group

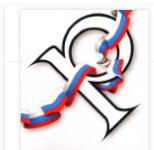

REGIONOLOGIYA-REGIONOLOGY RUSSIAN JOURNAL OF REGIONAL STUDIES $<$ Share This Journal

ISSN / eISSN 2413-1407/2587-8549

Publisher NATL RESEARCH OGAREV MORDOVIA STATE UNIV, 68-1 BOLSHEVISTSKAYA STR, SARANSK, RUSSIA, 430005

About 6

The "REGIONOLOGY" journal publishes original scientific papers on topical issues of Regional Politics, Economics and Sociology, as well as on analysis of comprehensive development of regions of the Russian Federation and foreign countries. The journal peer-review all papers submitted to the Editors for the purpose of their expert evaluation in the following fields of science and groups of specialties: Economy, Sociology, Political Science. Academic journal, has been published since October 1992. The Editors shall not provide any pay or agency services. All publications in the journal are free. The accelerated date of publication is not available. Manuscripts submitted simultaneously to other journals and papers, which in most part have already been published elsewhere as an article or part of another work, shall not be considered.

\section{General Information}

Society or Institution

Frequency

Country/Region

Aims and Scope

Instructions for Authors

Plagiarism Screening

Host Platform

Download Statistics
National Research Mordovia State

$$
\text { University }
$$

Quarterly

RUSSIAN FEDERATION

【 Visit Site

$\square$ Visit Site

【 Visit Site

Drupal

[ Visit Site
Journal Website

Issues Per Year

Primary Language 6

Editorial Board

Avg. Number of Weeks from Submission to Publication

Article DOls $\mathbf{a}$

Full-Text Formats
匹 Visit Site

Russian

¿ Visit Site

12

Yes

PDF 